\title{
RELATIONS OF SURFACE-WATER QUALITY TO STREAMFLOW IN THE ATLANTIC COASTAL, LOWER DELAWARE RIVER, AND DELAWARE BAY BASINS, NEW JERSEY, WATER YEARS 1976-93
}

Water-Resources Investigations Report 98-4244

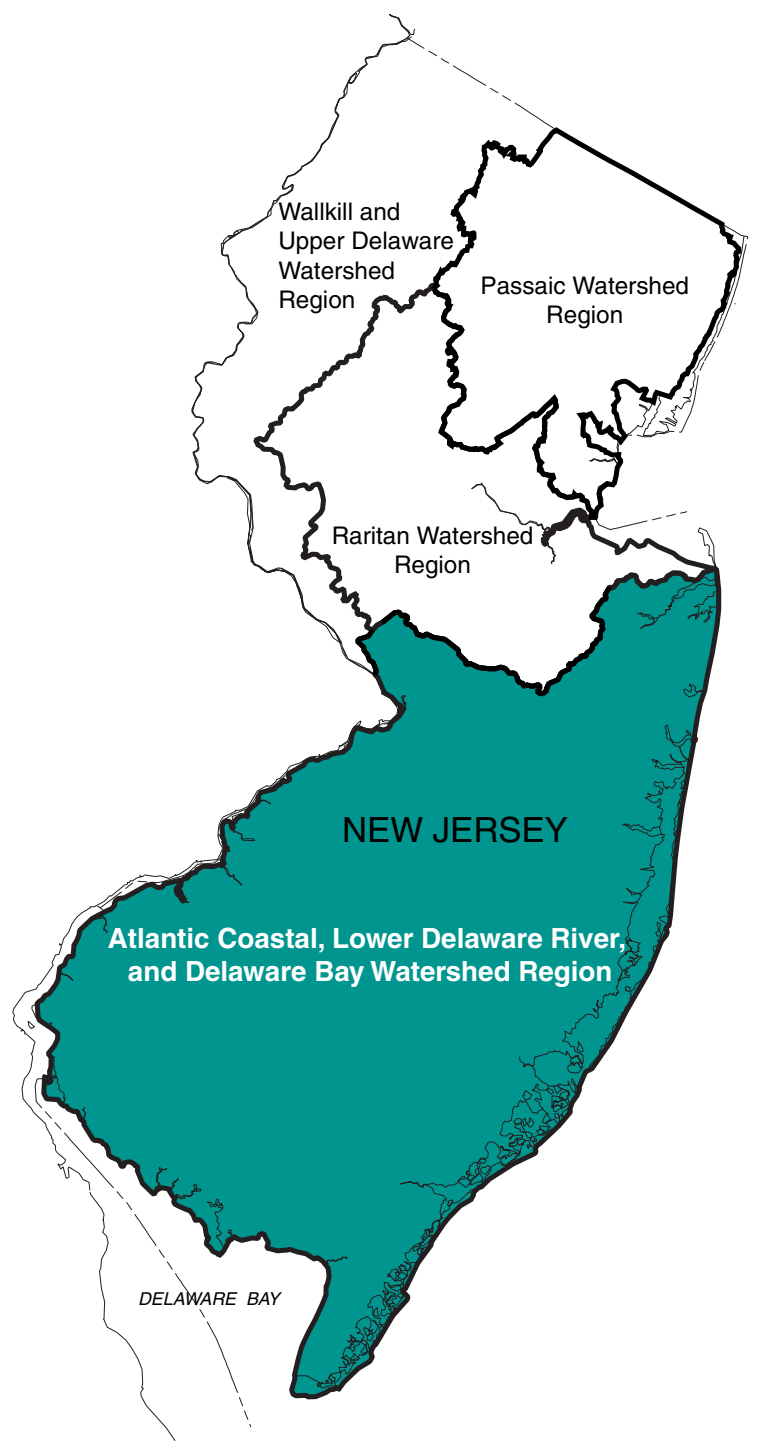

Prepared in cooperation with the NEW JERSEY DEPARTMENT OF ENVIRONMENTAL PROTECTION 


\section{RELATIONS OF SURFACE-WATER QUALITY TO STREAMFLOW IN THE ATLANTIC COASTAL, LOWER DELAWARE RIVER, AND DELAWARE BAY BASINS, NEW JERSEY, WATER YEARS 1976-93}

By Kathryn Hunchak-Kariouk, Debra E. Buxton, and R. Edward Hickman

U.S. Geological Survey

Water-Resources Investigations Report 98-4244

Prepared in cooperation with the NEW JERSEY DEPARTMENT OF ENVIRONMENTAL PROTECTION

West Trenton, New Jersey 1999 


\title{
U.S. DEPARTMENT OF THE INTERIOR
}

\author{
BRUCE BABBITT, secretary
}

\section{U.S. GEOLOGICAL SURVEY}

Charles G. Groat, Director

For additional information write to:

District Chief

U.S Geological Survey Mountain View Office Park

810 Bear Tavern Road, Suite 206

West Trenton, NJ 08628
Copies of this report can be purchased from:

U.S. Geological Survey

Branch of Information Services

Box 25286

Denver, CO 80225-0286 


\section{CONTENTS}

Page

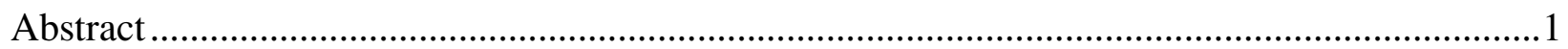

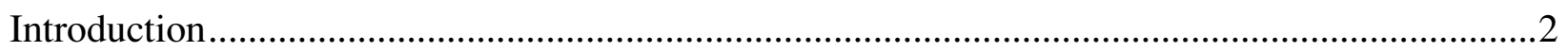

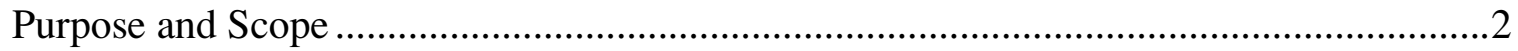

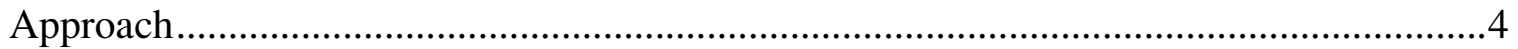

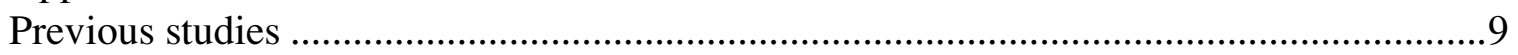

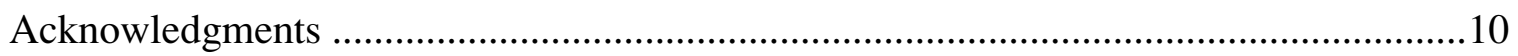

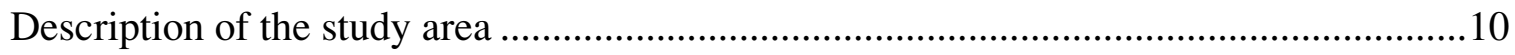

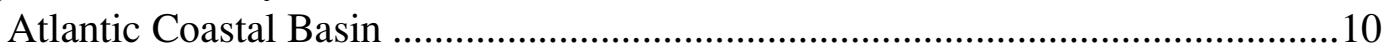

Manasquan River .............................................................................. 10

Toms River ...................................................................................... 14

Mullica River ....................................................................................... 14

Great Egg Harbor River ................................................................. 14

Lower Delaware River Basin........................................................................ 15

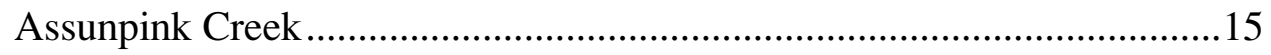

Crosswicks Creek ..............................................................................15

Rancocas Creek................................................................................15

Pennsauken Creek ..................................................................................... 16

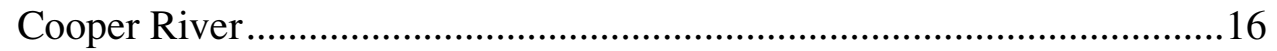

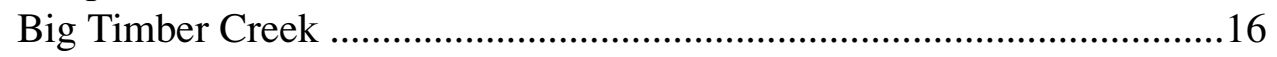

Raccoon Creek ................................................................................... 17

Oldmans Creek ..................................................................................... 17

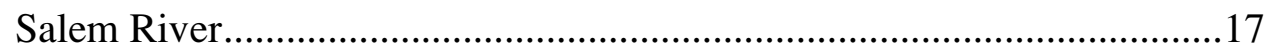

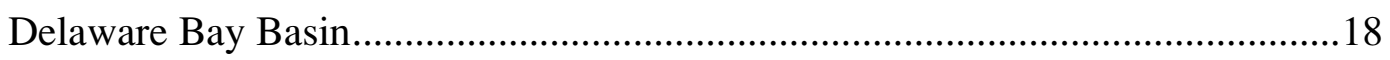

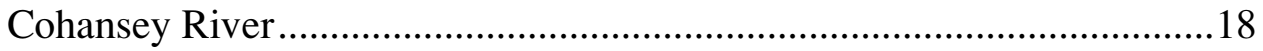

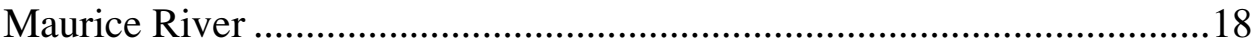

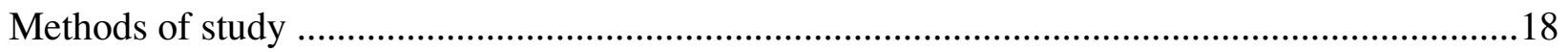

Selection of constituents, sites, and data sources..........................................................19

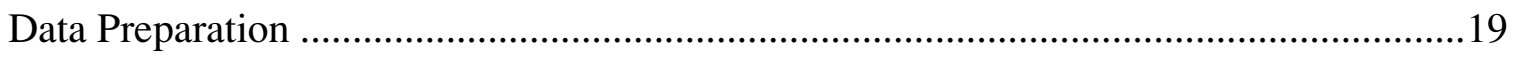

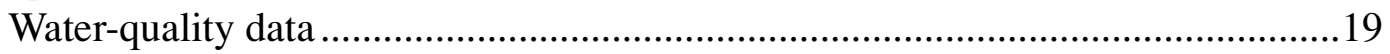

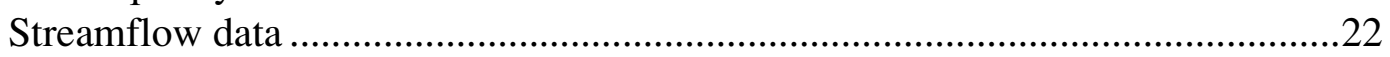

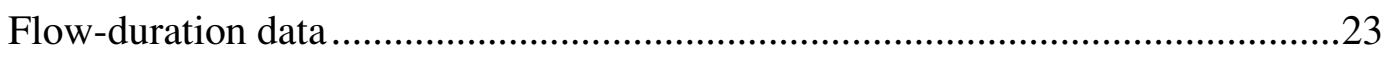

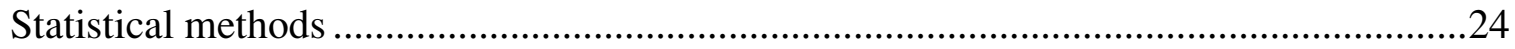

Calculation of medians .............................................................................24

Determination of relations of surface-water quality to streamflow ......................26

Relations of concentration to streamflow ...........................................26

Relations of load to streamflow ............................................................29

Trends in concentrations during low and high flows ...............................29

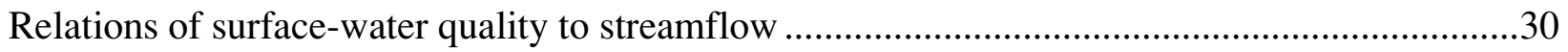

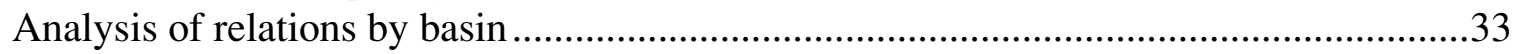

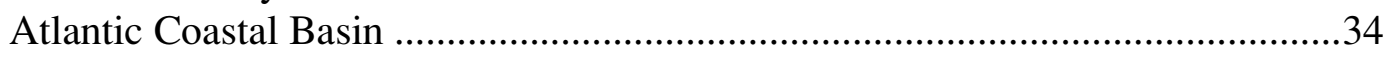

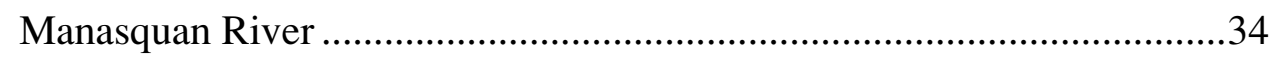

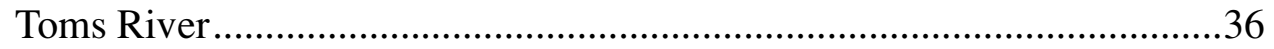




\section{CONTENTS-Continued}

Page

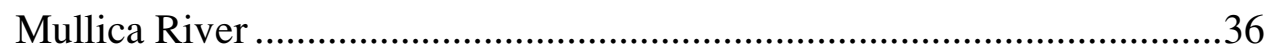

Great Egg Harbor River ..........................................................................44

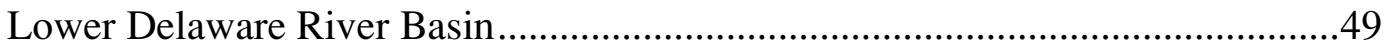

Assunpink Creek ...........................................................................49

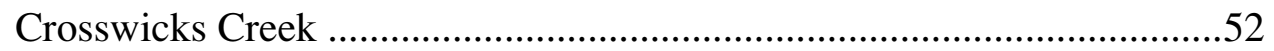

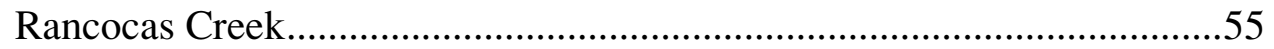

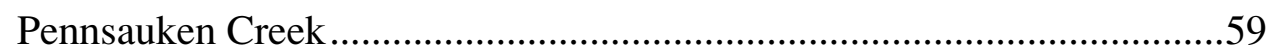

Cooper River .......................................................................................59

South Branch Big Timber Creek...............................................................63

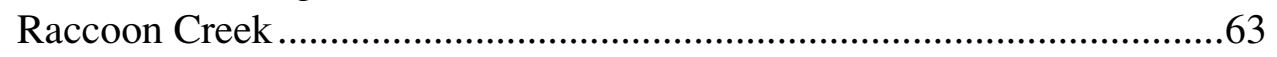

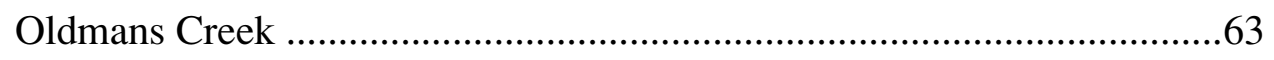

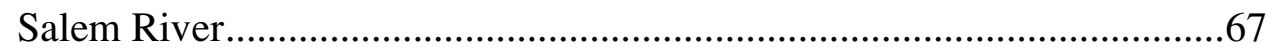

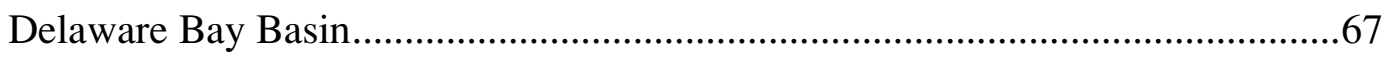

Cohansey River.......................................................................67

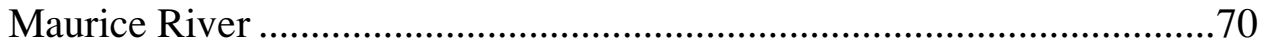

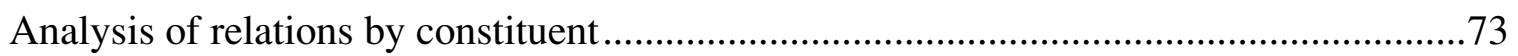

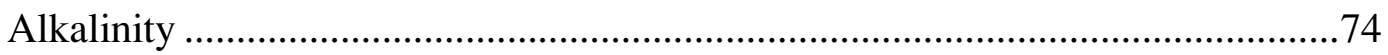

Relation of trends in concentration to flow conditions ............................74

Relation of load to streamflow............................................................ 74

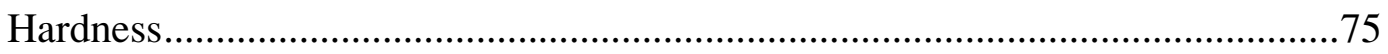

Relation of trends in concentration to flow conditions ...........................75

Relation of load to streamflow............................................................8

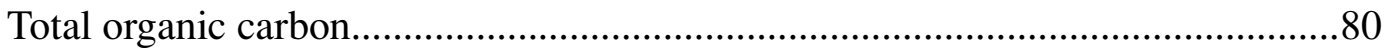

Relation of trends in concentration to flow conditions ...........................8 80

Relation of load to streamflow............................................................81

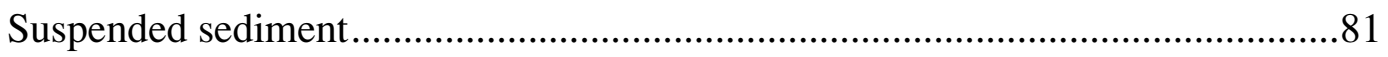

Relation of trends in concentration to flow conditions ............................81

Relation of load to streamflow............................................................86

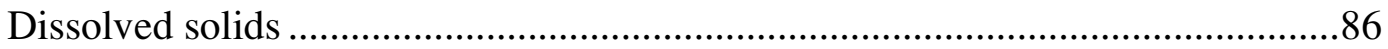

Relation of trends in concentration to flow conditions ...........................88

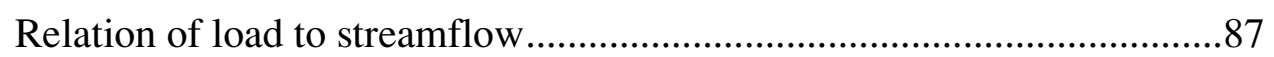

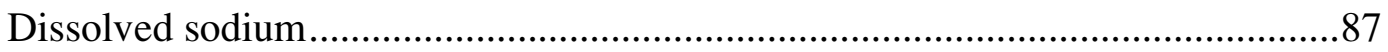

Relation of trends in concentration to flow conditions ............................90

Relation of load to streamflow ............................................................90

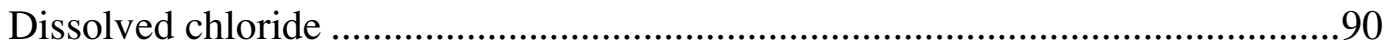

Relation of trends in concentration to flow conditions .............................91

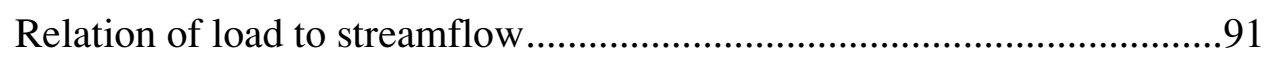

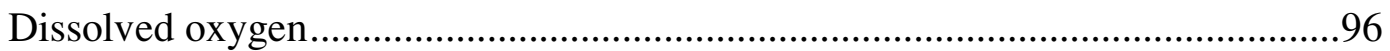

Relation of trends in concentration to flow conditions ............................96

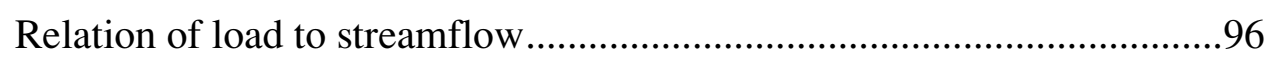

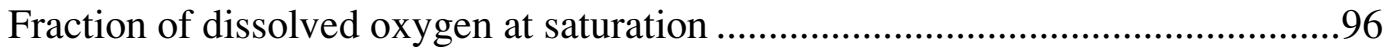




\section{CONTENTS-Continued}

Page

Relation of trends in concentration to flow conditions ............................97

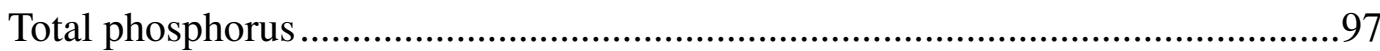

Relation of trends in concentration to flow conditions ..........................97

Relation of load to streamflow.............................................................104

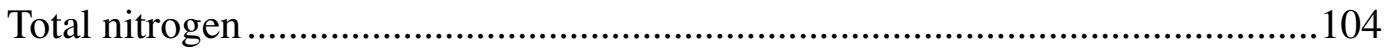

Relation of trends in concentration to flow conditions ...........................104

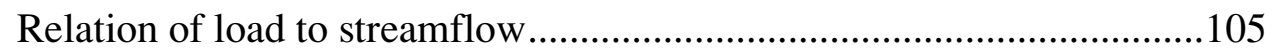

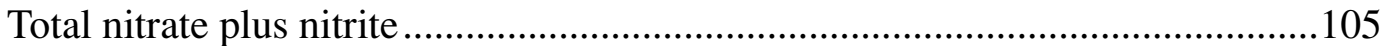

Relation of trends in concentration to flow conditions ............................108

Relation of load to streamflow............................................................108

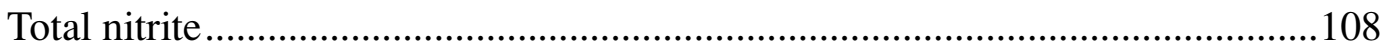

Relation of trends in concentration to flow conditions ..........................109

Relation of load to streamflow...........................................................109

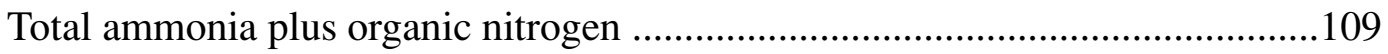

Relation of trends in concentration to flow conditions ........................... 114

Relation of load to streamflow..............................................................114

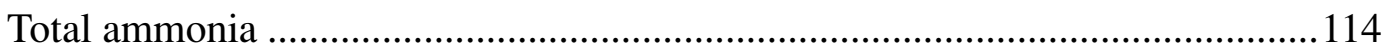

Relation of trends in concentration to flow conditions ........................115

Relation of load to streamflow............................................................ 115

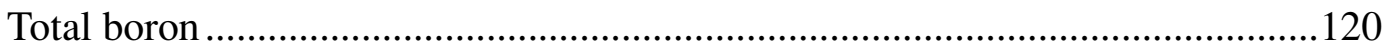

Relation of trends in concentration to flow conditions ...........................120

Relation of load to streamflow..............................................................120

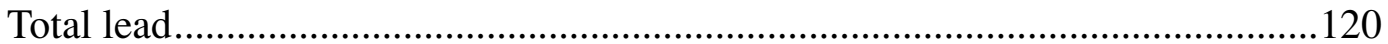

Relation of trends in concentration to flow conditions ..........................120

Relation of load to streamflow...........................................................121

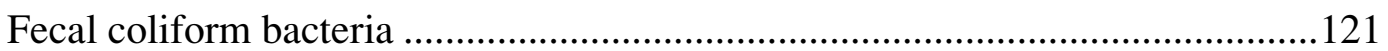

Relation of trends in concentration to flow conditions ..........................121

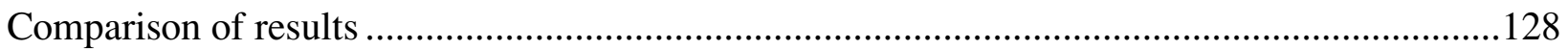

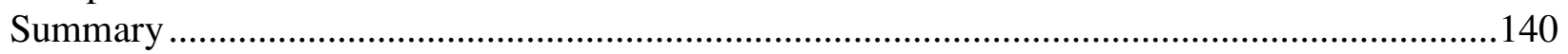

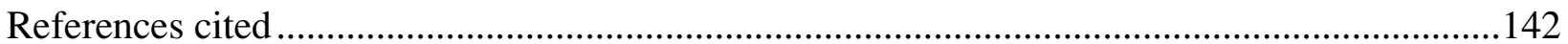

Appendixes 1-18. Relations of constituent concentration and load to streamflow and trends in concentration with time (Available on CD-ROM from U.S. Geological Survey, New Jersey District (609-771-3900):

1. Alkalinity

2. Hardness

3. Total organic carbon

4. Suspended sediment

5. Dissolved solids

6. Dissolved sodium

7. Dissolved chloride

8. Dissolved oxygen

9. Fraction of dissolved oxygen at saturation

10. Total phosphorus 


\section{CONTENTS-Continued}

Page

Appendixes

11. Total nitrogen

12. Total nitrate plus nitrite

13. Total nitrite

14. Total ammonia plus organic nitrogen

15. Total ammonia

16. Total boron

17. Total lead

18. Fecal coliform bacteria

\section{ILLUSTRATIONS}

Figure 1. Map showing four watershed regions in New Jersey

2. Graph showing hypothetical logarithmic plot of expected load-to-streamflow relations for a stream strongly affected by constant (point sources and ground water) and intermittent (nonpoint storm runoff) sources

3. Graphs showing example plot of relation of instream load of total nitrogen to instantaneous streamflow at water-quality stations in the Rockaway River Basin, New Jersey, 1985-91

4. Map showing locations of surface-water-quality stations and ambient biomonitoring network stations in the Atlantic Coastal Basin, New Jersey 11

5. Map showing locations of surface-water-quality stations and ambient biomonitoring network stations in the lower Delaware River and Delaware Bay Basins, New Jersey

6. Period of record of water-quality data for selected stations in the Atlantic Coastal, lower Delaware River, and Delaware Bay Basins, New Jersey, for water years 1976-93

7. Example page from Appendix 12 of graphs showing relation of concentration to streamflow, relation of load to streamflow, and trends in low- and high-flow concentrations for total nitrate plus nitrite at a station on the South Branch Rancocas Creek at Vincentown, New Jersey, water years 1976-93

8 - 43. Schematics showing:

8. Trends in alkalinity concentrations during (A) high- and (B) low-flow conditions, and $(\mathrm{C})$ relative slope of alkalinity load to streamflow at surface-water-quality stations in the Atlantic Coastal Basins, N.J., water years 1976-93.

9. Trends in alkalinity concentrations during (A) high- and (B) low-flow conditions, and $(C)$ relative slope of alkalinity load to streamflow at surface-water-quality stations in the lower Delaware River and Delaware Bay Basins, N.J., water years 1976-93

10. Trends in total hardness concentrations during (A) high- and (B) low-flow conditions, and $(\mathrm{C})$ relative slope of total hardness load to streamflow at surface-water-quality stations in the Atlantic Coastal Basins, N.J., water years 1976-93. 


\section{ILLUSTRATIONS-Continued}

Page

Figure 11. Trends in total hardness concentrations during (A) high- and (B) low-flow conditions, and $(\mathrm{C})$ relative slope of total hardness load to streamflow at surface-water-quality stations in the lower Delaware River and Delaware Bay Basins, N.J., water years 1976-93

12. Trends in total organic carbon concentrations during (A) high- and (B) low-flow conditions, and (C) relative slope of total organic carbon load to streamflow at surface-water-quality stations in the Atlantic Coastal Basins, N.J., water years 1976-93

13. Trends in total organic carbon concentrations during (A) high- and (B) low-flow conditions, and (C) relative slope of total organic carbon load to streamflow at surface-water-quality stations in the lower Delaware River and Delaware Bay Basins, N.J., water years 1976-93

14. Trends in suspended sediment concentrations during (A) high- and (B) low-flow conditions, and (C) relative slope of suspended sediment load to streamflow at surface-water-quality stations in the Atlantic Coastal Basins, N.J., water years 1976-93

15. Trends in suspended sediment concentrations during (A) high- and (B) low-flow conditions, and (C) relative slope of suspended sediment load to streamflow at surface-water-quality stations in the lower Delaware River and Delaware Bay Basins, N.J., water years 1976-93

16. Trends in dissolved solids concentrations during (A) high- and (B) low-flow conditions, and $(\mathrm{C})$ relative slope of dissolved solids load to streamflow at surface-water-quality stations in the Atlantic Coastal Basins, N.J., water years 1976-93.

17. Trends in dissolved solids concentrations during (A) high- and (B) low-flow conditions, and (C) relative slope of dissolved solids load to streamflow at surface-water-quality stations in the lower Delaware River and Delaware Bay Basins, N.J., water years 1976-93

18. Trends in dissolved sodium concentrations during (A) high- and (B) low-flow conditions, and (C) relative slope of dissolved sodium load to streamflow at surface-water-quality stations in the Atlantic Coastal Basins, N.J., water years 1976-93

19. Trends in dissolved sodium concentrations during (A) high- and (B) low-flow conditions, and (C) relative slope of dissolved sodium load to streamflow at surface-water-quality stations in the lower Delaware River and Delaware Bay Basins, N.J., water years 1976-93

20. Trends in dissolved chloride concentrations during (A) high- and (B) low-flow conditions, and (C) relative slope of dissolved chloride load to streamflow at surface-water-quality stations in the Atlantic Coastal Basins, N.J., water years 1976-93 


\section{ILLUSTRATIONS-Continued}

Page

Figure 21. Trends in dissolved chloride concentrations during (A) high- and (B) low-flow conditions, and (C) relative slope of dissolved chloride load to streamflow at surface-water-quality stations in the lower Delaware River and Delaware Bay Basins, N.J., water years 1976-93

22. Trends in dissolved oxygen concentrations during (A) high- and (B) low-flow conditions, and (C) relative slope of dissolved oxygen load to streamflow at surface-water-quality stations in the Atlantic Coastal Basins, N.J., water years 1976-93.

23. Trends in dissolved oxygen concentrations during (A) high- and (B) low-flow conditions, and (C) relative slope of dissolved oxygen load to streamflow at surface-water-quality stations in the lower Delaware River and Delaware Bay Basins, N.J., water years 1976-93

24. Trends in fraction of dissolved oxygen at saturation during (A) high- and

(B) low-flow conditions at surface-water-quality stations in the Atlantic Coastal Basins, N.J., water years 1976-93

25. Trends in fraction of dissolved oxygen at saturation during (A) high- and

(B) low-flow conditions at surface-water-quality stations in the lower Delaware River and Delaware Bay Basins, N.J., water years 1976-93.....

26. Trends in total phosphorus concentrations during (A) high- and (B) low-flow conditions, and (C) relative slope of total phosphorus load to streamflow at surface-water-quality stations in the Atlantic Coastal Basins, N.J., water years 1976-93

27. Trends in total phosphorus concentrations during (A) high- and (B) low-flow conditions, and (C) relative slope of total phosphorus load to streamflow at surface-water-quality stations in the lower Delaware River and Delaware Bay Basins, N.J., water years 1976-93.

28. Trends in total nitrogen concentrations during (A) high- and (B) low-flow conditions, and (C) relative slope of total nitrogen load to streamflow at surface-water-quality stations in the Atlantic Coastal Basins, N.J., water years 1976-93

29. Trends in total nitrogen concentrations during (A) high- and (B) low-flow conditions, and (C) relative slope of total nitrogen load to streamflow at surface-water-quality stations in the lower Delaware River and Delaware Bay Basins, N.J., water years 1976-93

30. Trends in total nitrate plus nitrite concentrations during (A) high- and (B) lowflow conditions, and (C) relative slope of nitrate plus nitrite load to streamflow at surface-water-quality stations in the Atlantic Coastal Basins, N.J., water years 1976-93

31. Trends in total nitrate plus nitrite concentrations during (A) high- and (B) lowflow conditions, and (C) relative slope of nitrate plus nitrite load to streamflow at surface-water-quality stations in the lower Delaware River and Delaware Bay Basins, N.J., water years 1976-93 


\section{ILLUSTRATIONS-Continued}

Page

Figure 32. Trends in total nitrite concentrations during (A) high- and (B) low-flow conditions, and (C) relative slope of total nitrite load to streamflow at surface-water-quality stations in the Atlantic Coastal Basins, N.J., water years 1976-93

33. Trends in total nitrite concentrations during (A) high- and (B) low-flow conditions, and (C) relative slope of total nitrite load to streamflow at surface-water-quality stations in the lower Delaware River and Delaware Bay Basins, N.J., water years 1976-93

34. Trends in total ammonia plus organic nitrogen concentrations during (A) highand (B) low-flow conditions, and (C) relative slope of total ammonia plus total organic nitrogen load to streamflow at surface-water-quality stations in the Atlantic Coastal Basins, N.J., water years 1976-93

35. Trends in total ammonia plus organic nitrogen concentrations during (A) highand (B) low-flow conditions, and (C) relative slope of total ammonia plus total organic nitrogen load to streamflow at surface-water-quality stations in the lower Delaware River and Delaware Bay Basins, N.J., water years 1976-93 .....117

36. Trends in total ammonia concentrations during (A) high- and (B) low-flow conditions, and (C) relative slope of total ammonia load to streamflow at surface-water-quality stations in the Atlantic Coastal Basins, N.J., water years 1976-93.

37. Trends in total ammonia concentrations during (A) high- and (B) low-flow conditions, and (C) relative slope of total ammonia load to streamflow at surface-water-quality stations in the lower Delaware River and Delaware Bay Basins, N.J., water years 1976-93

38. Trends in total boron concentrations during (A) high- and (B) low-flow conditions, and (C) relative slope of total boron load to streamflow at surfacewater-quality stations in the Atlantic Coastal Basins, N.J., water years 1976-93

39. Trends in total boron concentrations during (A) high- and (B) low-flow conditions, and (C) relative slope of total boron load to streamflow at surface-water-quality stations in the lower Delaware River and Delaware Bay Basins, N.J., water years 1976-93

40. Trends in total lead concentrations during (A) high- and (B) low-flow conditions, and (C) relative slope of total lead load to streamflow relations at surfacewater-quality stations in the Atlantic Coastal Basins, N.J., water years $1976-93$

41. Trends in total lead concentrations during (A) high- and (B) low-flow conditions, and (C) relative slope of total lead load to streamflow relations at surfacewater-quality stations in the lower Delaware River and Delaware Bay Basins, N.J., water years 1976-93 


\section{ILLUSTRATIONS-Continued}

Page

Figure 42. Trends in fecal coliform bacteria concentrations during (A) high- and (B) low-

flow conditions at surface-water-quality stations in the Atlantic Coastal

Basins, N.J., water years 1976-93.

43. Trends in fecal coliform bacteria concentrations during (A) high- and (B) low-

flow conditions at surface-water-quality stations in the lower Delaware

River and Delaware Bay Basins, N.J., water years 1976-93 .....

\section{TABLES}

Table 1. Description of, years of record for, and mean annual flow at, selected waterquality stations in the Atlantic Coastal, lower Delaware River, and Delaware Bay Basins, N.J. .8

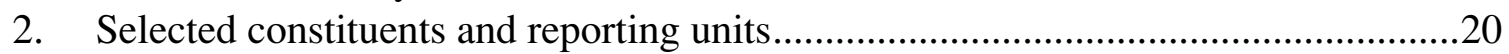

3. Estimated flow-duration values of mean daily discharge and data source for surface-water-quality stations in the Atlantic Coastal, lower Delaware River, and Delaware Bay Basins, N.J.

4. Estimated detection limits for selected constituents measured in the Atlantic Coastal, lower Delaware River, and Delaware Bay Basins, N.J., water years 1976-93.

5 - 32. Water quality and AMNET impairment status at water-quality stations

(a) Median concentrations, relations of concentration and load to streamflow, and directions of concentration trends for selected waterquality constituents (at indicated station), and (b) 1993 AMNET impairment status (in the vicinity of indicated station):

5. 01408000, Manasquan River at Squankum, N.J................................................35

6. 01408500, Toms River near Toms River, N.J. ..............................................37

7. 01409387, Mullica River at outlet of Atsion Lake, at Atsion, N.J. ..................38

8. 01409416, Hammonton Creek at Wescoatville, N.J........................................39

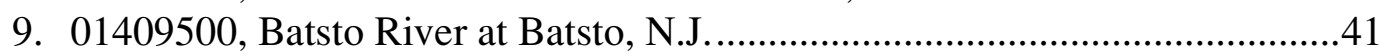

10. 01409815, West Branch Wading River at Maxwell, N.J.................................42

11. 01410000, Oswego River at Harrisville, N.J...................................................

12. 01410150, East Branch Bass River near New Gretna, N.J..............................45

13. 01410784, Great Egg Harbor River near Sicklerville, N.J. ...............................46

14. 01411000, Great Egg Harbor River at Folsom, N.J......................................4

15. 01411110, Great Egg Harbor River at Weymouth, N.J...................................48

16. 01463620, Assunpink Creek near Clarksville, N.J......................................50

17. 01464000, Assunpink Creek at Trenton, N.J................................................51

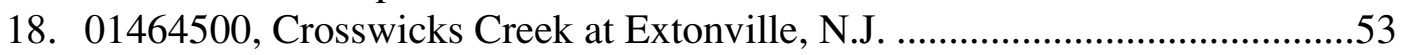

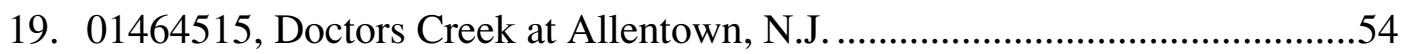

20. 01465850, South Branch Rancocas Creek at Vincentown, N.J.......................56

21. 01466500, McDonalds Branch in Lebanon State Forest, N.J..........................57

22. 01467000, North Branch Rancocas Creek at Pemberton, N.J.........................58

23. 01467069, North Branch Pennsauken Creek near Moorestown, N.J. ..............60 


\section{TABLES-Continued}

Page

Table 24. 01467081, South Branch Pennsauken Creek at Cherry Hill, N.J. ..................61

25. 01467150, Cooper River at Haddonfield, N.J. ..........................................62

26. 01467329, South Branch Big Timber Creek at Blackwood Terrace, N.J........64

27. 01477120, Raccoon Creek near Swedesboro, N.J........................................65

28. 01477510, Oldmans Creek at Porches Mill, N.J............................................66

29. 01482500, Salem River at Woodstown, N.J..................................................68

30. 01412800, Cohansey River at Seeley, N.J..................................................69

31. 01411500, Maurice River at Norma, N.J........................................................ 71

32. 01411800 , Maurice River near Millville, N.J............................................72

33. Concentration trends during low flow at surface-water-quality stations in the Atlantic Coastal Basins, N.J., water years 1976-93 .......................................130

34. Concentration trends during low flow at surface-water-quality stations in the lower Delaware River and Delaware Bay Basins, N.J., water years 1976-93

35. Concentration trends during high flow at surface-water-quality stations in the Atlantic Coastal Basins, N.J., water years 1976-93.

36. Concentration trends during high flow at surface-water-quality stations in the lower Delaware River and Delaware Bay Basins, N.J., water years 1976-93

37. Seasonal dependency at surface-water-quality stations in the Atlantic Coastal Basins, N.J., water years 1976-93....

38. Seasonal dependency at surface-water-quality stations in the lower Delaware River and Delaware Bay Basins, N.J., water years 1976-93

39. Maximum, minimum, and spread of load-to-streamflow slopes for selected constituents at surface-water-quality stations in the Atlantic Coastal Basins, N.J., water years 1976-93.

40. Maximum, minimum, and spread of load-to-streamflow slopes for selected constituents at surface-water-quality stations in the lower Delaware River and Delaware Bay Basins, N.J., water years 1976-93

41. Maximum, minimum, and spread of load-to-streamflow slopes for selected nutrients at surface-water-quality stations in the Atlantic Coastal Basins, N.J., water years 1976-93

42. Maximum, minimum, and spread of load-to-streamflow slopes for selected nutrients at surface-water-quality stations in the lower Delaware River and Delaware Bay Basins, N.J., water years 1976-93 


\section{CONVERSION FACTORS AND ABBREVIATED WATER-QUALITY UNITS}

Multiply

mile (mi)

square mile $\left(\mathrm{mi}^{2}\right)$

square mile $\left(\mathrm{mi}^{2}\right)$

gallon (gal)

gallon (gal)

cubic foot $\left(\mathrm{ft}^{3}\right)$

cubic foot per second $\left(\mathrm{ft}^{3} / \mathrm{s}\right)$

pounds per day (lb/d)
By

$\underline{\text { To obtain }}$

$\underline{\text { Length }}$

1.609

kilometer

$\underline{\text { Area }}$

259.0

2.590

hectare

square kilometer

$\underline{\text { Volume }}$

3.785

0.003785

0.02832

Flow

$$
0.02832
$$

0.4536

cubic meter per second

kilograms per day

$\underline{\text { Mass }}$

pound, avoirdupois (lb)

0.4536

kilogram

Temperature given in degrees Fahrenheit $\left({ }^{\circ} \mathrm{F}\right)$ and Celsius $\left({ }^{\circ} \mathrm{C}\right)$ can be converted to degrees Celsius $\left({ }^{\circ} \mathrm{C}\right)$ and Kelvin $\left({ }^{\circ} \mathrm{K}\right)$ by the following equations:

$$
\begin{aligned}
& { }^{\circ} \mathrm{C}=5 / 9 \times\left({ }^{\circ} \mathrm{F}-32\right) \\
& { }^{\circ} \mathrm{K}=273.15+{ }^{\circ} \mathrm{C}
\end{aligned}
$$

\begin{tabular}{|c|c|c|c|}
\hline$\mu \mathrm{m}$ & - micrometer & DO & - dissolved oxygen \\
\hline $\mathrm{s} / \mathrm{d}$ & - seconds per day & FDO & - fraction of dissolved oxygen \\
\hline $\mathrm{mg} / \mathrm{L}$ & - milligrams per liter & & at saturation \\
\hline$\mu \mathrm{g} / \mathrm{L}$ & - micrograms per liter & $\mathrm{TP}$ & - total phosphorus \\
\hline \multirow{2}{*}{ MPN/100mL- } & - most probable number of & TN & - total nitrogen \\
\hline & bacteria per 100 milliliters & NO32 & - total nitrate plus nitrite \\
\hline ALK & - alkalinity & $\mathrm{NO} 2$ & - total nitrite \\
\hline HARD & - hardness & TAON & - total ammonia plus organic \\
\hline TOC & - total organic carbon & & nitrogen \\
\hline SS & - suspended sediment & NH4 & - total ammonia \\
\hline DS & - dissolved solids & B & - total boron \\
\hline NA & - dissolved sodium & PB & - total lead \\
\hline CL & - dissolved chloride & BACT & - fecal coliform bacteria \\
\hline
\end{tabular}

\section{Water-quality abbreviations}




\title{
RELATIONS OF SURFACE-WATER QUALITY TO STREAMFLOW IN THE ATLANTIC COASTAL, LOWER DELAWARE RIVER, AND DELAWARE BAY BASINS, NEW JERSEY, WATER YEARS 1976-93
}

\author{
By Kathryn Hunchak-Kariouk, Debra E. Buxton, and R. Edward Hickman
}

\begin{abstract}
Relations of water quality to streamflow were determined for 18 water-quality constituents at 28 surface-water-quality stations within the drainage area of the Atlantic Coastal, lower Delaware River, and Delaware Bay Basins for water years 1976-93. Surface-water-quality and streamflow data were evaluated for trends (through time) in constituent concentrations during high and low flows, and relations between constituent concentration and streamflow, and between constituent load and streamflow, were determined. Median concentrations were calculated for the entire period of study (water years 1976-93) and for the last 5 years of the period of study (water years 1989-93) to determine whether any large variation in concentration exists between the two periods. Medians also were used to determine the seasonal Kendall's tau statistic, which was then used to evaluate trends in concentrations during high and low flows.

Trends in constituent concentrations during high and low flows were evaluated to determine whether the distribution of the observations changes through time for intermittent (nonpoint storm runoff) and constant (point sources and ground water) sources, respectively. High- and low-flow trends in concentrations were determined for some constituents at 26 of the 28 water-quality stations. Seasonal effects on the relations of concentration to streamflow are evident for 10 constituents at 14 or more stations. Dissolved oxygen shows seasonal dependency at all stations. Negative slopes of relations of concentration to streamflow, which indicate a decrease in concentration at high flows, predominate over positive slopes because of dilution of instream concentrations from storm runoff.
\end{abstract}

The slopes of the regression lines of load to streamflow were determined in order to show the relative contributions to the instream load from constant (point sources and ground water) and intermittent sources (storm runoff). Greater slope values indicate larger contributions from storm runoff to instream load, which most likely indicate an increased relative importance of nonpoint sources. Load-to-streamflow relations along a stream reach that tend to increase in a downstream direction indicate the increased relative importance of contributions from storm runoff. Likewise, load-to-streamflow relations along a stream reach that tend to decrease in a downstream direction indicate the increased relative importance of point sources and ground-water discharge.

The magnitudes of the load slopes for five constituents increase in the downstream direction along the Great Egg Harbor River, indicating an increased relative importance of storm runoff for these constituents along the river. The magnitudes of the load slopes for 11 constituents decrease in the downstream direction along the Assunpink Creek and for 5 constituents along the Maurice River, indicating a decreased relative importance of storm runoff for these constituents along the rivers. 


\section{INTRODUCTION}

The New Jersey Department of Environmental Protection (NJDEP) has initiated an innovative watershed approach to water-quality management in order to attain State-mandated goals for the quality of surface water (New Jersey Department of Environmental Protection, 1989). Water-quality will be assessed and management policies will be developed on the basis of contributing factors, such as nonpoint source contributions, headwaters destruction, and habitat degradation, within the watershed or basin. This approach requires evaluation of the effects of point and nonpoint source contributions on the quality of surface water within a watershed. To facilitate the assessment of surface-water quality, the State is divided into four regions on the basis of watershed-management issues and hydrogeologic boundaries defined by the U.S. Geological Survey (USGS) (fig. 1).

The USGS, in cooperation with the NJDEP, has developed a watershed-based method for relating water quality to streamflow to assess the relative contributions of constant (point sources and ground-water discharge) and intermittent (nonpoint sources and storm runoff) sources of constituents to New Jersey streams in all four regions. The initial study was conducted by using a watershed-based method for the region comprising the Hackensack, Passaic, Elizabeth, and Rahway River Basins (Buxton and others, 1998). The other regions consist of (1) the Wallkill River and upper Delaware River Basins; (2) the Raritan River Basin; and (3) the Atlantic Coastal, lower Delaware River, and Delaware Bay Basins.

\section{Purpose and Scope}

This report presents the results of analyses for 18 water-quality constituents in samples collected at 28 surface-water-quality stations within the Atlantic Coastal, lower Delaware River, and Delaware Bay Basins (referred to as the study area) during water years ${ }^{1}$ 1976-93 (October 1, 1975, through September 30, 1993). Relations between each of the 18 constituents and streamflow at the 28 stations over the period of record were determined by testing for trends in the concentrations of constituents during low and high flows. Qualitative values of contributions from constant (point sources and ground water) and intermittent (nonpoint storm runoff) sources were estimated statistically by examining the relations between concentrations of constituents and streamflow, and load and streamflow.

Results of analyses are presented in three ways - in tables for each station with median concentrations, the regression slopes of concentration and load to streamflow, and the directions of the trends in concentrations during low and high flows for all constituents; in schematics for each constituent showing regional trends in concentration during low and high flows and the slopes of load to streamflow; and in graphs for each constituent by station showing relations of concentration to streamflow, load to streamflow, and trends of concentrations during low and high flows.

\footnotetext{
${ }^{1} \mathrm{~A}$ water year is the 12 -month period from October 1 through September 30 and is designated by the calendar year in which it ends.
} 


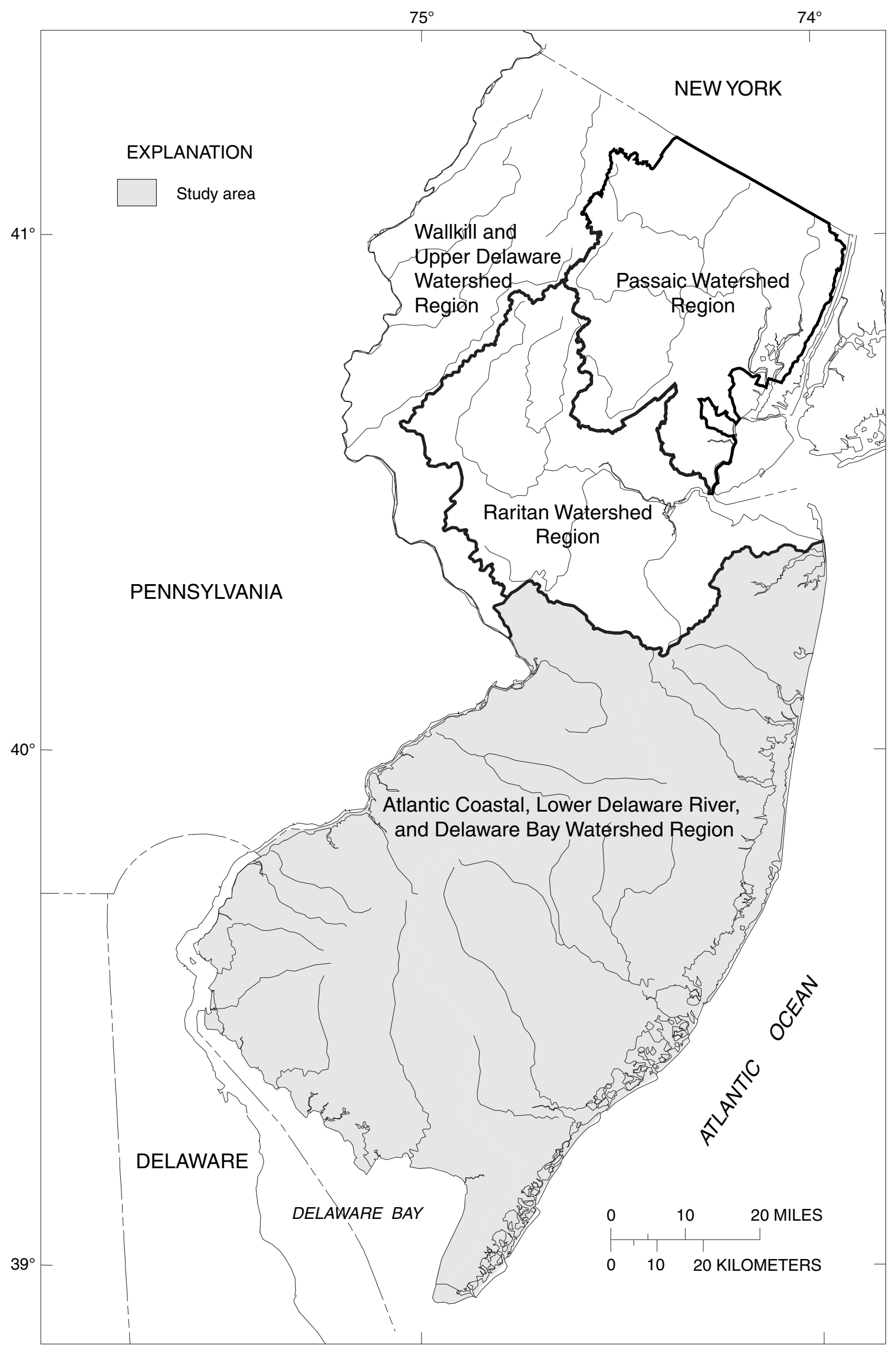

Figure 1. Four watershed regions in New Jersey. 


\section{Approach}

A river receives constituents from point and nonpoint sources within the contributing drainage basin. Point sources are discrete, identifiable origins of constituents, such as permitted discharges from municipal- and industrial-wastewater treatment facilities, that contribute water to a stream at a constant rate, independent of streamflow conditions. Constituents from more diffuse, nonpoint sources are transported to the river by storm runoff from agricultural, residential, and urban areas and impervious surfaces (highways and parking lots), and by ground water that could contain effluent from leaking underground-storage tanks, septic systems, and landfills. Storm runoff, composed of overland runoff (water that flows overland when precipitation exceeds the infiltration rate) and interflow (infiltrated water that moves in a horizontal direction in the lower permeable subsoil), contributes to a stream intermittently, depending on storm intensity and frequency, and only during high flows (Chow, 1964; Novotny and Chesters, 1981). Ground-water discharge to a stream is almost constant, although it varies slightly with season and precipitation rate. Instream concentrations of constituents are a summation of the contributions from constant (point sources and ground-water discharge) and intermittent (storm runoff) sources.

The magnitude, or steepness, of the regression slope for constituent loads to streamflow indicates the relative contributions of constant and intermittent sources at a river location. The steeper the slope, the greater the contribution from nonpoint sources during increased streamflow. If the contributions to instream load are mainly from point sources and ground water, instream load will remain constant with increasing streamflow, and the regression slope of load to streamflow will be approximately zero (fig. 2). If, however, storm runoff contributes a disproportionate amount to instream load, instream load will increase with increasing streamflow, and the regression slope of load to streamflow will be greater than zero (fig. 2). A steep slope does not imply that contributions from constant sources are unimportant, just that intermittent sources contribute more to instream load during high flows than do constant sources. Price and Schaefer (1995) used this approach (steepness of the load-to-streamflow regression line) to assess the relative contributions of permitted and nonpermitted sources in the Musconetcong, Rockaway, and Whippany River Basins. An idealized example of the relation of load to streamflow is shown in figure 3. For site 01380500, the Rockaway River above the reservoir at Boonton, the slope of the regression line is steeper (the estimated total median load from permitted point sources upstream was approximately $100 \mathrm{lbs} / \mathrm{d}$ ) than the slope for site 01381200, Rockaway River at Pine Brook (the estimated median load from permitted point sources was approximately 1,000 lbs/d). In the example, the relative importance of nonpoint sources is greater at station 01380500 than at site 01381200 , and the relative importance of point sources is greater at site 01381200 than at site 01380500 .

Concentrations of constituents cannot be related to streamflow in this way because contributions from storm runoff are flow dependent, and a small concentration can represent a large instream load during high-flow conditions. If constituents are contributed to a stream mostly from constant sources, then instream concentrations will be diluted during periods of high flow. If, however, storm runoff contributes significant amounts of constituents to a stream, then 


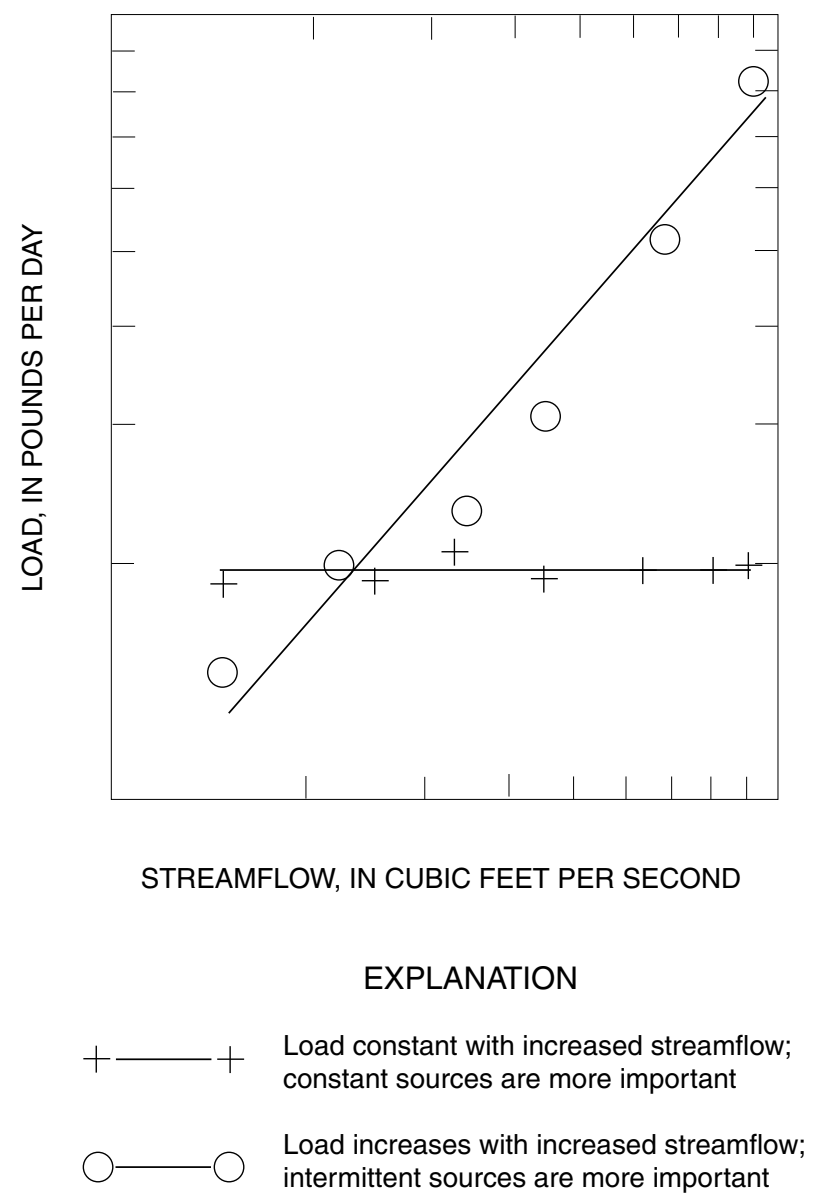

Figure 2. Hypothetical logarithmic plot of expected load-to-streamflow relations for a stream strongly affected by constant (point source and ground water) and intermittent (nonpoint storm runoff) sources. 


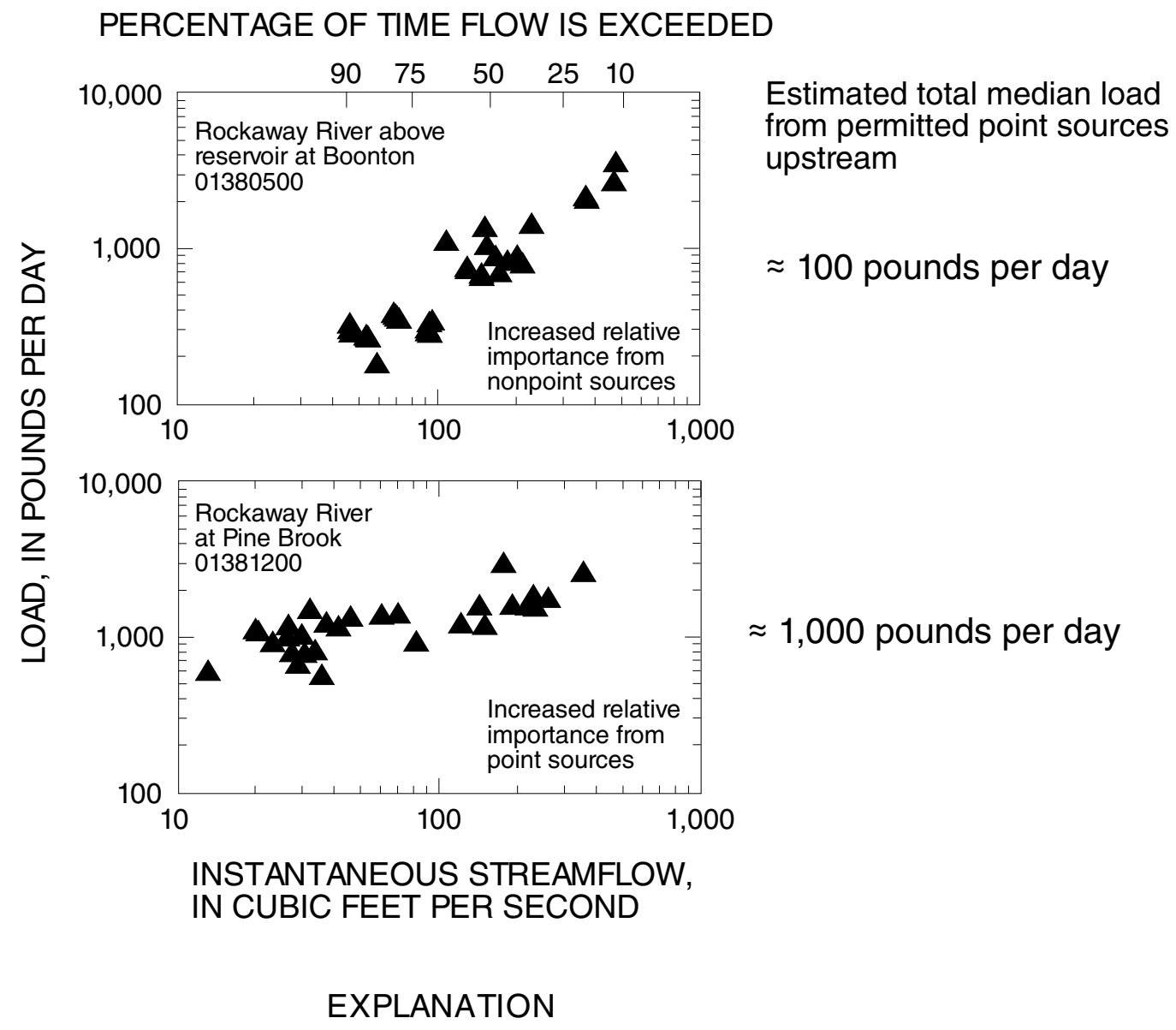

$\Delta$ Water-quality sample

Figure 3. Relation of instream load of total nitrogen to instantaneous streamflow at water-quality stations in the Rockaway River Basin, New Jersey, 1985-91. 
the extent of dilution during periods of high flow will be reduced. The use of loads (mass per time) instead of concentrations (mass per volume) removes the influence of changing streamflow (volume per time) on instream constituent amounts (Buxton and others, 1998).

The instream load also can be affected by contributions from ground water and streambed sediment. Ground-water contributions to streams during low flow can be significant, but are less likely to affect surface-water quality during high-flow conditions when ground-water contributions are diluted. In some hydrologic systems, the scour of streambed sediment during high flows can contribute to the instream load. Rosensteel and Strom (1991) collected waterquality samples from the Pompton and Passaic Rivers during storms and found that most of the observed increase in the load of total phosphorus at high flows was attributable to the dissolved fraction of the phosphorus load, indicating that the load contributed by sediment scour probably was significant.

Comparisons of trends in constituent concentrations during high and low flows can indicate changes over time in the contributions from intermittent and constant sources, respectively. Positive trends during high flows indicate an increase in the storm runoff contributions over time, whereas negative trends indicate a decrease in the storm runoff contributions. Positive trends during low flows indicate an increase in the contributions from point sources and ground water or both over time, whereas negative trends indicate a decrease in the contributions from point sources and ground water.

The study involved several phases of multidisciplinary activity starting with the selection of the surface-water-quality stations (table 1), constituents, and the period of record. Waterquality and instantaneous-streamflow data were retrieved from the National Water Information System (NWIS) data base (Hutchison, 1975), which is maintained by the USGS. The waterquality and instantaneous-streamflow data underwent extensive quality-assurance procedures.

The data base created for this study was maintained with the Statistical Analysis System (SAS), a statistically based integrated software system that provides data access, management, analysis, and presentation. With SAS, median concentrations and relations of surface-water quality to streamflow were determined for each constituent at each station. The types of relations analyzed are concentration to streamflow, load to streamflow, and concentration trends during low- and high-flow conditions.

Graphs, schematics, and tables were generated to show the statistical results. Results are presented in the text first by basin and compared with the impairment index generated by the NJDEP's Ambient Biomonitoring Network (AMNET) biological assessment, and then by constituent. Results of the three surface-water quality to streamflow analyses are presented graphically by constituent for each station in appendixes $1-18^{2}$.

\footnotetext{
${ }^{2}$ Appendixes 1-18 containing relations of surface-water quality to streamflow are available on a CD-ROM; contact the New Jersey District Office of the USGS in West Trenton, N.J., for more information or to obtain copies of the CD-ROM.
} 
Table 1. Description of, years of record for, and mean annual flow at, selected water-quality stations in the Atlantic Coastal, lower Delaware River, and Delaware Bay Basins, N.J.

[ND, no data for site; $\mathrm{mi}^{2}$, square miles; $\mathrm{ft}^{3} / \mathrm{s}$, cubic feet per second]

\begin{tabular}{|c|c|c|c|c|c|}
\hline $\begin{array}{l}\text { Station } \\
\text { number }\end{array}$ & Station name & $\begin{array}{l}\text { Latitude/ } \\
\text { longitude }\end{array}$ & $\begin{array}{l}\text { Drainage } \\
\text { area in } \mathrm{mi}^{2}\end{array}$ & $\begin{array}{c}\text { Daily } \\
\text { streamflow } \\
\text { record } \\
\text { (water years) }\end{array}$ & $\begin{array}{l}\text { Mean annual flow } \\
\text { in } \mathrm{ft}^{3} / \mathrm{s} \\
\text { (period of record) }\end{array}$ \\
\hline \multicolumn{6}{|c|}{$\underline{\text { Atlantic Coastal Basin }}$} \\
\hline 01408000 & Manasquan River at Squankum & $400947 / 740921$ & 44.0 & $1932-93$ & 74.7 \\
\hline${ }^{2} 01408500$ & Toms River near Toms River & $395910 / 741329$ & ) 123 & $1929-93$ & 212 \\
\hline${ }^{1} 01409387$ & Mullica River at Outlet of Atsion Lake, at Atsion & $394425 / 744337$ & 26.7 & ND & ND \\
\hline${ }^{1} 01409416$ & Hammonton Creek at Westcoatville & $393802 / 744305$ & 9.6 & ND & ND \\
\hline 01409500 & Batsto River at Batsto & $393833 / 743900$ & 67.8 & 1928-93 & 122 \\
\hline${ }^{2} 01409815$ & West Branch Wading River at Maxwell & $394030 / 743228$ & 85.9 & ND & ND \\
\hline 01410000 & Oswego River at Harrisville & $393947 / 743126$ & 72.5 & $1931-93$ & 86.5 \\
\hline 01410150 & East Branch Bass River near New Gretna & $393723 / 742630$ & 8.1 & $1978-93$ & 15.3 \\
\hline${ }^{1} 01410784$ & Great Egg Harbor River near Sicklerville & $394402 / 745705$ & 15.1 & ND & ND \\
\hline 01411000 & Great Egg Harbor River at Folsom & $393542 / 745106$ & 57.1 & $1925-93$ & 85.8 \\
\hline${ }^{1} 01411110$ & Great Egg Harbor River at Weymouth & $393050 / 744647$ & 154 & ND & ND \\
\hline \multicolumn{6}{|c|}{$\underline{\text { Delaware River Basin }}$} \\
\hline 01463620 & Assunpink Creek near Clarksville & $401611 / 744020$ & 34.3 & 1973-93 & 52.3 \\
\hline 01464000 & Assunpink Creek at Trenton & $401327 / 744458$ & 90.6 & 1924-93 & 131 \\
\hline 01464500 & Crosswicks Creek at Extonville & $400815 / 743602$ & 81.5 & $1940-93$ & 134 \\
\hline${ }^{1} 01464515$ & Doctors Creek at Allentown & $401037 / 743557$ & 17.4 & ND & ND \\
\hline${ }^{1} 01465850$ & South Branch Rancocas Creek at Vincetown & $395622 / 744550$ & 64.5 & ND & ND \\
\hline 01466500 & McDonalds Branch in Lebanon State Forest & $395305 / 743020$ & 2.4 & $1954-93$ & 2.2 \\
\hline 01467000 & North Branch Rancocas Creek at Pemberton & $395810 / 744105$ & 118 & $1922-93$ & 171 \\
\hline${ }^{1} 01467069$ & North Branch Pennsauken Creek near Moorestown & $395707 / 745810$ & 12.8 & ND & ND \\
\hline 01467081 & South Branch Pennsauken Creek at Cherry Hill & $395630 / 750005$ & 8.9 & $1968-93$ & 18.7 \\
\hline 01467150 & Cooper River at Haddonfield & $395411 / 750119$ & 17.0 & $1964-93$ & 34.5 \\
\hline${ }^{1} 01467329$ & $\begin{array}{l}\text { South Branch Big Timber Creek at Blackwood } \\
\text { Terrace }\end{array}$ & $394805 / 750427$ & 19.1 & ND & ND \\
\hline 01477120 & Raccoon Creek near Swedesboro & $394428 / 751533$ & 26.9 & $1966-93$ & 40.3 \\
\hline${ }^{1} 01477510$ & Oldmans Creek at Porches Mill & $394157 / 752001$ & 21.0 & ND & ND \\
\hline${ }^{1} 01482500$ & Salem River at Woodstown & $393836 / 751952$ & 14.6 & ND & ND \\
\hline \multicolumn{6}{|c|}{$\underline{\text { Delaware Bay Basin }}$} \\
\hline${ }^{2} 01411500$ & Maurice River at Norma & $392942 / 750438$ & 112 & 1933-93 & 165 \\
\hline 01411800 & Maurice River near Millville & $392652 / 750422$ & 191 & $1992-93$ & 242 \\
\hline${ }^{1} 01412800$ & Cohansey River at Seeley & $392821 / 751521$ & 28.0 & ND & ND \\
\hline
\end{tabular}

${ }^{1}$ Water-quality station only

${ }^{2}$ NASQAN (National Stream Quality Accounting Network) station 


\section{$\underline{\text { Previous Studies }}$}

Water-quality studies have been conducted by the USGS, in cooperation with State and local agencies, in New Jersey since the early 1960's. Three more recent USGS studies report the effects of nonpoint source contamination on New Jersey streams. Schornick and Fishel (1980) reported the effect of storm runoff on the surface-water quality of the Mill Creek Basin in Willingboro, Burlington County. Fusillo (1981) reported the effects of suburban residential development on surface- and ground-water quality in the upper Great Egg Harbor River Basin in Winslow Township, Camden County. Price and Schaefer (1995) reported estimated loads of selected constituents in the Musconetcong, Rockaway, and Whippany River Basins in northern New Jersey.

Several previous studies address surface-water issues in the river basins investigated in this study. Anderson and George (1966) reported the results of a statewide reconnaissance study of the water-quality characteristics of New Jersey streams. Anderson and McCarthy (1963) described the chemical characteristics of streams in the Delaware River Basin. Hely and Olmsted (1963) presented relations between streamflow characteristics and the environment in the Delaware River region. Parker and others (1964) discussed the water resources of the Delaware River Basin. Ivahnenko and Buxton (1994) discussed the presence of pesticides from agricultural runoff in the Manasquan River, and Buxton and Dunne (1993) reported water-quality data for the Shark River at Remsen Mill, New Jersey. Hickman (1992) presented water-quality data collected from field reconnaissance surveys of selected estuaries in southern New Jersey, and Hickman (1995) reported the statistical characteristics of stream discharge in tributaries of selected estuaries in the Coastal Plain. Schornick and Ram (1978) discussed nitrification in four acidic streams in southern New Jersey. Mansue (1972) reported the suspended-sediment yields of streams in the Coastal Plain draining into the Delaware River estuary. Keighton (1965) studied the water quality of the Delaware River from Bristol to Marcus Hook, Pennsylvania; Keighton (1966) described the fresh-water discharge-salinity relations in the tidal Delaware River; and Keighton (1969) reported water quality in the Delaware River estuary from Trenton, New Jersey, to Reedy Island, Delaware, during the 1965-66 drought. Hochreiter (1982) reported on the chemical quality of the water and surficial bed material in the Delaware River estuary and adjacent New Jersey tributaries, and Hochreiter and Kozinski (1985) described the water quality and bed material in streams in Logan Township, Gloucester County.

Several USGS studies were conducted to evaluate surface-water characteristics and waterquality trends in New Jersey. Low-flow characteristics and flow durations of New Jersey streams were reported by Gillespie and Schopp (1982). Hay and Campbell (1990) identified statewide water-quality trends in New Jersey streams. Robinson and Pak (1993) summarized the water quality of selected New Jersey streams for water years 1987-89. Statewide monthly statistical summaries of surface-water temperatures during 1955-93 were presented by Reed and HunchakKariouk (1995). Buxton and others (1998) present relations of surface-water quality to streamflow in the Hackensack, Passaic, Elizabeth, and Rahway River Basins for water years 1976-93. 


\section{Acknowledgments}

The authors thank Kevin Berry and Daniel VanAbs, NJDEP, Office of Environmental Planning, for their cooperation and assistance in planning this report; William Summer, USGS, for his extensive programing for data manipulations and schematics; and Denis Sun, USGS, for applying his computer expertise to the design and production of the CD-ROM.

\section{Description of the Study Area}

The study area is in the southern half of New Jersey and includes rivers that drain into the Atlantic Ocean, lower Delaware River and Delaware Bay (figs. 4 and 5). Most of the study area is in the New Jersey Coastal Plain, which consists of unconsolidated sediments of alternating layers of sand, gravel, silt, and clay that dip gently to the southeast. This system of aquifers and confining units can be characterized as an independent hydrologic system. In the Coastal Plain, more than 75 percent of the streamflow is derived from ground-water discharge to stream channels because of the physiographic, geologic, hydrologic, and climatic conditions of the region (Vowinkel and Foster, 1981). More than 75 percent of the freshwater supply in the Coastal Plain comes from ground water (U.S. Geological Survey, 1984). The relative contributions of constant and intermittent sources to streams in the Coastal Plain are likely influenced by the ground-water quality in this region of the State.

\section{Atlantic Coastal Basin}

The Atlantic Coastal Basin (fig. 4) includes rivers from the Navesink River in Monmouth County southward to Cape May, New Jersey, that drain into the Atlantic Ocean. In this study, surface-water-quality and streamflow data were analyzed for four smaller basins contained within this region-Manasquan, Toms, Mullica, and Great Egg Harbor.

\section{Manasquan River}

The Manasquan River is 23 miles long and drains an area of about $81 \mathrm{mi}^{2}$. The headwaters start in central Monmouth County; then it flows in a southeasterly direction along the Ocean-Monmouth County line towards the Atlantic Ocean (New Jersey Department of Environmental Protection and Energy, 1993). One surface-water gaging and water-quality station is located on the Manasquan River at Squankum (01408000). At this station, mean annual flow for water years 1932-93 is estimated to be $74.7 \mathrm{ft}^{3} / \mathrm{s}$; water-quality data are available for the period of record water years 1963-93 (table 1; fig. 6) (Bauersfeld and others, 1994).

Land use in the basin is about one-half agricultural-crop and pasture land and one-half residential. Several lakes and ponds in the area are used for recreation (New Jersey Department of Environmental Protection and Energy, 1993). 


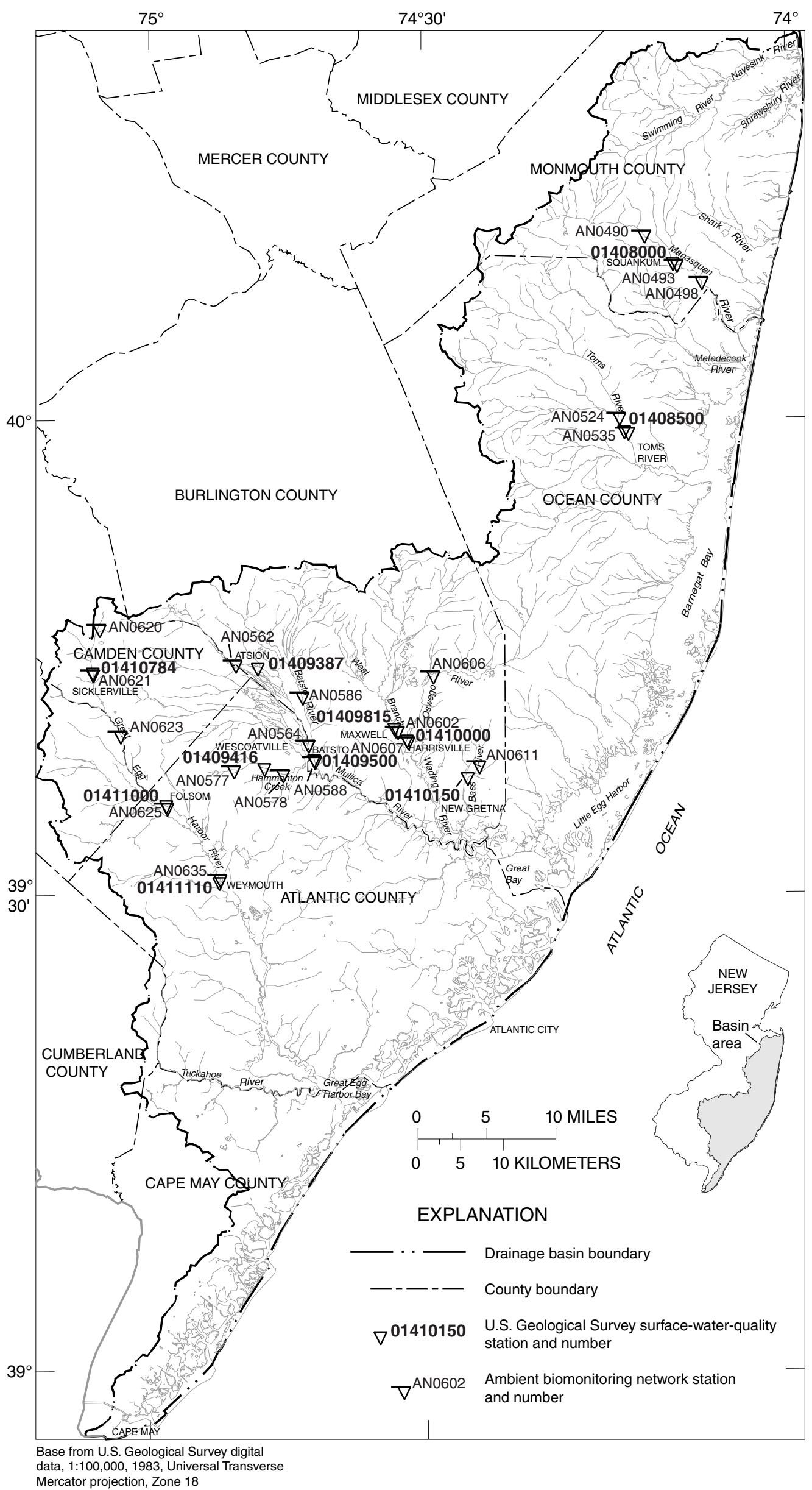

Figure 4. Locations of surface-water-quality stations and ambient biomonitoring network stations in the Atlantic Coastal Basin, New Jersey. 


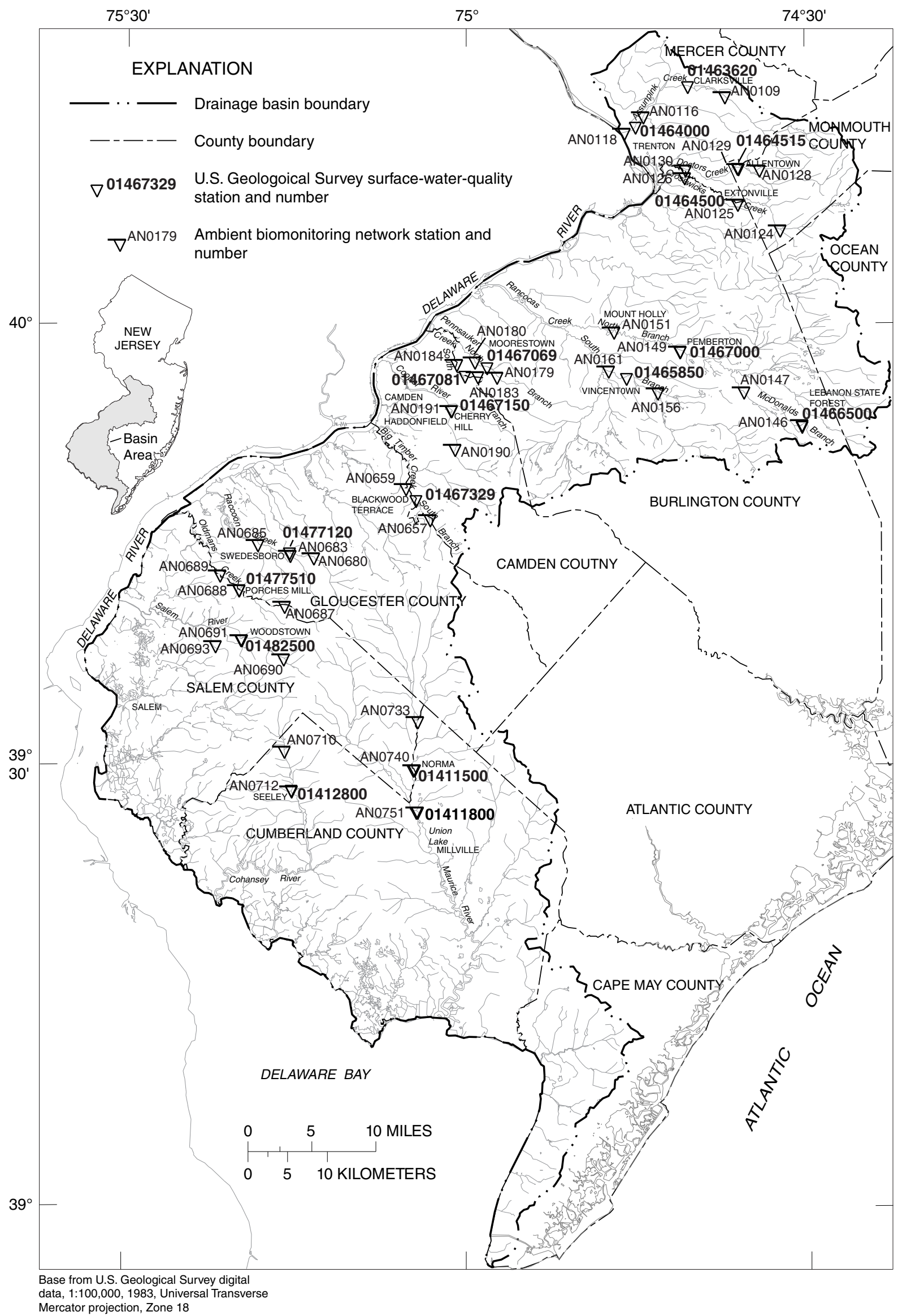

Figure 5. Locations of surface-water-quality stations and ambient biomonitoring network stations in the lower Delaware River and Delaware Bay Basins, New Jersey. 


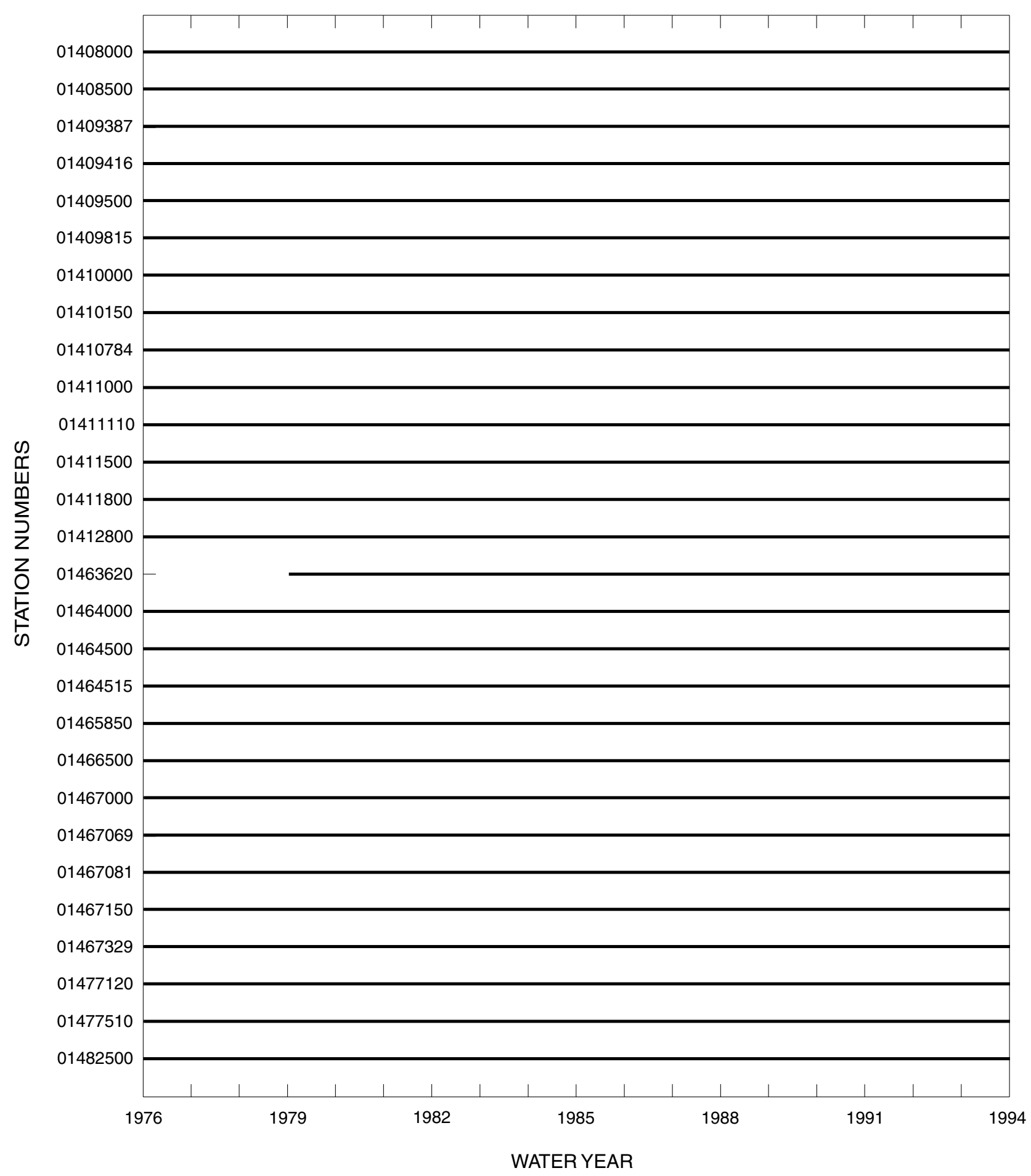

Figure 6. Period of record (at least one measurement per year) of water-quality data for selected stations in the Atlantic Coastal, lower Delaware River, and Delaware Bay Basins, New Jersey, for water years 1976-93. (Station names are given in table 1.) 


\section{$\underline{\text { Toms River }}$}

Toms River is 31 miles long and drains an area of $124 \mathrm{mi}^{2}$. It flows from western Ocean and Monmouth Counties southeast to Barnegat Bay with many small tributaries feeding into it along the way (New Jersey Department of Environmental Protection and Energy, 1993). Mean annual flow for water years 1929-93 is estimated to be $212 \mathrm{ft}^{3} / \mathrm{s}$ at the surface-water gaging station on the Toms River near Toms River (01408500) (Bauersfeld and others, 1994). The only water-quality station on the river is at Toms River (01408500) where the period of record for water-quality data is water years 1963-93 (fig. 6) (Bauersfeld and others, 1994).

Land use in the basin is about 50 percent forested; the remaining 50 percent is residential, military, and agricultural land use. Residential and commercial development is on the rise (New Jersey Department of Environmental Protection and Energy, 1993).

\section{$\underline{\text { Mullica River }}$}

The Mullica River and its tributaries drain about $561 \mathrm{mi}^{2}$. The Mullica River is about 45 miles long. The river's major tributaries include Hammonton Creek (9 miles long), Batsto River (18 miles long), Wading River (30 miles long), Oswego River (21 miles long), and Bass River (8 miles long) (New Jersey Department of Environmental Protection and Energy, 1993). The Mullica River flows into Great Bay, which then meets the Atlantic Ocean. Mean annual flow for water years 1928-93 is estimated to be $122 \mathrm{ft}^{3} / \mathrm{s}$ at the surface-water gaging station on the Mullica River at Batsto (01409500) (Bauersfeld and others, 1994). The five major tributaries and the Mullica River each have one water-quality station (table 1 ). The period of record for waterquality-data collection for each station is shown in figure 6.

Land use in the basin is mainly undeveloped State park land and forested. There are some agricultural and developed areas (New Jersey Department of Environmental Protection and Energy, 1993).

\section{Great Egg Harbor River}

The Great Egg Harbor River is about 49 miles long and drains an area of $304 \mathrm{mi}^{2}$. The river flows into Great Egg Harbor Bay, then into the Atlantic Ocean (New Jersey Department of Environmental Protection and Energy, 1993). Mean annual flow for water years 1925-93 is estimated to be $85.8 \mathrm{ft}^{3} / \mathrm{s}$ at the surface-water gaging station on the Great Egg Harbor River at Folsom (01411000) (Bauersfeld and others, 1994). Three water-quality stations are located on the Great Egg Harbor River (table 1). The period of record for water-quality-data collection for each station is shown in figure 6.

Land use in the basin is mainly forested; the remainder is agricultural and developed (New Jersey Department of Environmental Protection and Energy, 1993). 


\section{Lower Delaware River Basin}

The lower Delaware River Basin (fig. 5) from just south of Trenton to where the river widens into Delaware Bay contains many tributaries. In this study, surface-water-quality and streamflow data were analyzed for nine streams that flow directly into the lower Delaware River-Cooper and Salem Rivers, and Assunpink, Crosswicks, Rancocas, Pennsauken, South Branch of the Big Timber, Raccoon, and Oldmans Creeks.

\section{$\underline{\text { Assunpink Creek }}$}

Assunpink Creek is about 25 miles long and drains an area of $91 \mathrm{mi}^{2}$. The flow begins in Monmouth County, continues through central Mercer County, then discharges into the Delaware River at Trenton (New Jersey Department of Environmental Protection and Energy, 1993). A mean annual flow of $131 \mathrm{ft}^{3} / \mathrm{s}$ is estimated for water years 1924-93 at the surface-water gaging station on the Assunpink Creek at Trenton (01464000) (Bauersfeld and others, 1994). Two waterquality stations are located on the Assunpink Creek (table 1). The period of record for waterquality-data collection for each station is shown in figure 6.

Land use in the basin is varied. It ranges from undeveloped and agricultural to suburban and urban (New Jersey Department of Environmental Protection and Energy, 1993).

\section{Crosswicks Creek}

Crosswicks Creek is about 25 miles long and drains an area of $146 \mathrm{mi}^{2}$. It drains parts of Mercer, Monmouth, Ocean, and Burlington Counties (New Jersey Department of Environmental Protection and Energy, 1993). A mean annual flow of $134 \mathrm{ft}^{3} / \mathrm{s}$ is estimated for water years 1940-93 at the surface-water gaging station on Crosswicks Creek at Extonville (01464500) (Bauersfeld and others, 1994). The only water-quality station on the creek is at Extonville (01464500), where the period of record for water-quality-data collection is water years 1965-93 (fig. 6) (Bauersfeld and others, 1994).

Land use in this basin is diverse. The Crosswicks Creek drainage area includes agricultural land, forested areas, residential areas, commercial zones, and military installations (New Jersey Department of Environmental Protection and Energy, 1993).

\section{$\underline{\text { Rancocas Creek }}$}

Rancocas Creek basin covers about $380 \mathrm{mi}^{2}$, making it the largest basin in south-central New Jersey. The North Branch drains $167 \mathrm{mi}^{2}$ of the total area, and the South Branch drains $144 \mathrm{mi}^{2}$ of the total area. The North Branch is 31 miles long and is fed by the McDonalds Branch; the South Branch is 27 miles long. The main stem of the Rancocas Creek is about 8 miles long and drains an area of about $49 \mathrm{mi}^{2}$. Tides influence stream levels for 15 stream miles upstream from the Delaware River, along the entire length of the Rancocas Creek main stem to Mount Holly on the North Branch and to Vincentown on the South Branch (New Jersey Department of Environmental Protection and Energy, 1993). Mean annual flow for water years 
1922-93 is estimated to be $171 \mathrm{ft}^{3} / \mathrm{s}$ at the surface-water gaging station on the North Branch Rancocas Creek at Pemberton (01467000) (Bauersfeld and others, 1994). One water-quality station is located on each of the North and South Branches of Rancocas Creek (table 1). The one water-quality station on McDonald's Branch in Lebanon State Park is a hydrologic benchmark station. The hydrology and water quality at this station are representative of that in undeveloped areas in the New Jersey Pinelands. The period of record for water-quality-data collection for each station is shown in figure 6.

Land use in the basin is about 50 percent forested. The remaining land use is agricultural, urban and suburban (New Jersey Department of Environmental Protection and Energy, 1993).

\section{Pennsauken Creek}

Pennsauken Creek drains about $33 \mathrm{mi}^{2}$ of southwestern Burlington County and northern Camden County. The main stem is 3 miles long; the North Branch is 10 miles long; and the South Branch is 11 miles long. Tides influence stream levels along the entire main stem and for a few miles along each of the two main branches of the river (New Jersey Department of Environmental Protection and Energy, 1993). Mean annual flow for water years 1968-93 is estimated to be $18.7 \mathrm{ft}^{3} / \mathrm{s}$ at the surface-water gaging station on the South Branch Pennsauken Creek at Cherry Hill (01467081) (Bauersfeld and others, 1994). The North and South Branches of Pennsauken Creek have one water-quality station each (table 1). Station 01467069 is on the North Branch of Pennsauken Creek near Morristown. The period of record for water-quality-data collection for each station is shown in figure 6.

Land use in the basin is mostly urban and suburban with some industrial areas mainly at the mouth of Pennsauken Creek. The remainder of the land is farmland and forested land (New Jersey Department of Environmental Protection and Energy, 1993).

\section{Cooper River}

The Cooper River is 16 miles long and covers an area of about $40 \mathrm{mi}^{2}$. It flows from northwest Camden County to the Delaware River at Camden (New Jersey Department of Environmental Protection and Energy, 1993). Mean annual flow for water years 1964-93 is estimated to be $34.5 \mathrm{ft}^{3} / \mathrm{s}$ at the surface-water gaging station on the Cooper River at Haddonfield (01467150) (Bauersfeld and others, 1994). The only water-quality station on the river is at Haddonfield (01467150) where the period of record for water-quality-data collection is water years 1968-93 (fig. 6) (Bauersfeld and others, 1994).

Land use in the basin is primarily urban and suburban. There is intense development along the main stem (New Jersey Department of Environmental Protection and Energy, 1993).

\section{Big Timber Creek}

Big Timber Creek drains an area of $63 \mathrm{mi}^{2}$. The South Branch of Timber Creek is 11 miles long; the North Branch is 10 miles long; and the main stem is less than 4 miles long (New Jersey Department of Environmental Protection and Energy, 1993). There has never been a 
surface-water gaging station on Big Timber Creek or either branch of Big Timber Creek. One water-quality station is located on the South Branch of Big Timber Creek, a second-order stream, at Blackwood Terrace (01467329), where the period of record for water-quality-data collection is water years 1976-93 (fig. 6) (Bauersfeld and others, 1994).

Land use in the basin is mostly urban and suburban. There are forests at the headwaters of the creek and cities where the creek flows into the Delaware River (New Jersey Department of Environmental Protection and Energy, 1993).

\section{$\underline{\text { Raccoon Creek }}$}

Raccoon Creek is about 19 miles long and drains an area of $40 \mathrm{mi}^{2}$. Tidal marshes are present at the mouth of Raccoon Creek, and the lower half of the creek is tidal (New Jersey Department of Environmental Protection and Energy, 1993). Mean annual flow for water years 1966-93 is estimated to be $40.3 \mathrm{ft}^{3} / \mathrm{s}$ at the surface-water gaging station on Raccoon Creek near Swedesboro (01477120) (Bauersfeld and others, 1994). One water-quality station is located on Raccoon Creek at Swedesboro (01477120). The period of record for water-quality-data collection is water years 1965-93 (fig. 6) (Bauersfeld and others, 1994).

Land use in the basin is mainly agricultural and rural. Industries are located along the lower tidal section of the creek (New Jersey Department of Environmental Protection and Energy, 1993).

\section{Oldmans Creek}

Oldmans Creek is 20 miles long and drains an area of $44 \mathrm{mi}^{2}$. Tidal marshes are present at the mouth of the creek, and the lower third of the creek is tidal (New Jersey Department of Environmental Protection and Energy, 1993). Mean annual flow for water years 1932-40 is estimated to be $29.0 \mathrm{ft}^{3} / \mathrm{s}$ at the discontinued surface-water gaging station on Oldmans Creek near Woodstown, New Jersey (01477500) (Gillespie and Schopp,1982). One water-quality station is located on Oldmans Creek at Porches Mill (01477510), where the period of record for waterquality-data collection is water years 1975-93 (fig. 6) (Bauersfeld and others, 1994).

Land use in the basin is mainly agricultural and forested. There are some residential and industrial areas (New Jersey Department of Environmental Protection and Energy, 1993).

\section{$\underline{\text { Salem River }}$}

The Salem River is 32 miles long and drains an area of $114 \mathrm{mi}^{2}$. Most of the lower part of the river is tidal (New Jersey Department of Environmental Protection and Energy, 1993). Mean annual flow for March to September 1940, December 1941 to January 1985, and June to December 1989 is estimated to be $19.3 \mathrm{ft}^{3} / \mathrm{s}$ at the discontinued surface-water gaging station on the Salem River at Woodstown (01482500) (Bauersfeld and others, 1990). One water-quality station is located on the Salem River at Woodstown (01482500), where the period of record for water-quality-data collection is water years 1973-93 (fig. 6) (Bauersfeld and others, 1994). 
Almost one-half of the land use in the basin is agricultural (cropland). The remainder of the land use is forested (woodlands), undeveloped (tidal/freshwater marshes), urban, and agricultural (pastures) (New Jersey Department of Environmental Protection and Energy, 1993)

\section{Delaware Bay Basin}

The Delaware Bay Basin (fig.5) is in south New Jersey. The rivers in this basin-the Cohansey and the Maurice Rivers-flow mainly in a southerly direction and into Delaware Bay.

\section{Cohansey River}

The Cohansey River is almost 30 miles long and drains an area of $105 \mathrm{mi}^{2}$. The low relief in this area results in many small tributaries (New Jersey Department of Environmental Protection and Energy, 1993). Mean annual flow for water years 1951-67 is estimated to be $1.81 \mathrm{ft}^{3} / \mathrm{s}$ at the discontinued surface-water gaging station on the West Branch of the Cohansey River at Seeley (01412500) (Gillespie and Schopp,1982). One water-quality station is located on the Cohansey River at Seeley (01412800); the period of record for water-quality-data collection is water years 1975-93 (fig. 6) (Bauersfeld and others, 1994).

The main land use in the basin is agricultural. Much of the land remains forested (New Jersey Department of Environmental Protection and Energy, 1993).

\section{Maurice River}

The Maurice River is about 50 miles long and drains an area of $386 \mathrm{mi}^{2}$. Downstream from Union Lake, the river is influenced by tides (New Jersey Department of Environmental Protection and Energy, 1993). Mean annual flow for water years 1992-93 is estimated to be $242 \mathrm{ft}^{3} / \mathrm{s}$ at the surface-water gaging station on the Maurice River near Millville (01411800) (Bauersfeld and others, 1994). One water-quality station is located on the Maurice River near Millville (01411800); the period of record for water-quality-data collection is water years 1968-93 (fig. 6) (Bauersfeld and others, 1994).

The main land use in the basin is agricultural. Much of the land remains forested (New Jersey Department of Environmental Protection and Energy, 1993).

\section{METHODS OF STUDY}

The following section describes the methods and criteria used for the selection of constituents, sites, and data sources. Methods for data preparation, quality assurance, and statistical analyses are described. 


\section{Selection of Constituents, Sites, and Data Sources}

Constituents were chosen on the basis of their usefulness as indicators of the quality of the surface water and usefulness in developing effective surface-water-quality management practices. The 18 constituents selected include aggregate water properties (properties that include concentrations of several different chemical species), major ions, dissolved oxygen, nutrients, metals, and bacteria (table 2).

The basins contain 25 water-quality stations (table 1) with data from water years 1976-93 that are part of the USGS/NJDEP Cooperative Ambient Surface Water Quality Network and 3 water-quality stations that are part of the National Stream Quality Accounting Network (NASQAN). Eighteen of the stations also are operated as surface-water gaging stations. These stations were chosen on the basis of the locations and periods of record.

Water-quality and streamflow data were retrieved from the NWIS data base. Waterquality data for water years 1976-93 are available for 27 stations; partial records are available for one station (fig.6). Streamflow data are available for 16 water-quality stations for water years 1976-93.

\section{Data Preparation}

Water-quality and instantaneous-streamflow data retrieved from the NWIS data base were reviewed extensively for accuracy and were maintained in a SAS data base. Values of dissolved nitrate plus nitrite and dissolved nitrite were substituted for values of total nitrate plus nitrite and total nitrite where the latter were missing. This substitution is appropriate because nitrate and nitrite are anions that are poorly absorbed to mineral surfaces, and therefore, are present in ambient water almost exclusively as dissolved species (Hem, 1985). Where both dissolved and total concentration values were available for nitrate plus nitrite and nitrite, little or no difference was observed.

\section{Water-Quality Data}

Values for the fraction of dissolved oxygen at saturation and concentrations of hardness, total organic carbon, and total nitrogen were calculated.

The fraction of dissolved oxygen at saturation is the ratio of the measured dissolved oxygen concentration to the dissolved oxygen concentration at saturation, in percent, computed by using the following equation:

where

$$
F D O=100\left[\frac{D O}{D O_{\text {sat }}}\right]
$$

$F D O=$ fraction of dissolved oxygen at saturation;

$D O=$ dissolved oxygen concentration, in milligrams per liter; and

$D O_{\text {sat }}=$ dissolved oxygen at saturation, in milligrams per liter. 
Table 2. Selected constiuents and reporting units

[mg/L, milligrams per liter; $\mathrm{CaCO}_{3}$, calcium carbonate; $\mathrm{C}$, carbon; $\mathrm{Na}$, sodium; $\mathrm{Cl}$, chloride; $\mathrm{P}$, phosphorus; $\mathrm{N}$, nitrogen; $\mu \mathrm{g} / \mathrm{L}$, micrograms per liter; $\mathrm{B}$, boron; $\mathrm{Pb}$, lead; MPN/100 mL, most probable number per 100 milliliters.]

\begin{tabular}{|c|c|}
\hline Constituent & Reporting unit \\
\hline Alkalinity & $\mathrm{mg} / \mathrm{L}$ as $\mathrm{CaCO}_{3}$ \\
\hline Hardness $^{1}$ & $\mathrm{mg} / \mathrm{L}$ as $\mathrm{CaCO}_{3}$ \\
\hline Total organic carbon ${ }^{1}$ & $\mathrm{mg} / \mathrm{L}$ as $\mathrm{C}$ \\
\hline Suspended sediment & $\mathrm{mg} / \mathrm{L}$ \\
\hline Dissolved solids & $\mathrm{mg} / \mathrm{L}$ \\
\hline Dissolved sodium & $\mathrm{mg} / \mathrm{L}$ as $\mathrm{Na}$ \\
\hline Dissolved chloride & $\mathrm{mg} / \mathrm{L}$ as $\mathrm{Cl}$ \\
\hline Dissolved oxygen & $\mathrm{mg} / \mathrm{L}$ \\
\hline Fraction of dissolved oxygen at saturation ${ }^{1}$ & Percent \\
\hline Total phosphorus & $\mathrm{mg} / \mathrm{L}$ as $\mathrm{P}$ \\
\hline Total nitrogen ${ }^{1}$ & $\mathrm{mg} / \mathrm{L}$ as $\mathrm{N}$ \\
\hline Total nitrate plus nitrite & $\mathrm{mg} / \mathrm{L}$ as $\mathrm{N}$ \\
\hline Total nitrite & $\mathrm{mg} / \mathrm{L}$ as $\mathrm{N}$ \\
\hline Total ammonia plus organic nitrogen & $\mathrm{mg} / \mathrm{L}$ as $\mathrm{N}$ \\
\hline Total ammonia & $\mathrm{mg} / \mathrm{L}$ as $\mathrm{N}$ \\
\hline Total boron & $\mu \mathrm{g} / \mathrm{L}$ as $\mathrm{B}$ \\
\hline Total lead & $\mu \mathrm{g} / \mathrm{L}$ as $\mathrm{Pb}$ \\
\hline Fecal coliform bacteria & MPN/100 mL \\
\hline
\end{tabular}

1 Values of constituent or property are calculated. 
The following evaluation by R.F. Weiss (R.J. Pickering, U.S. Geological Survey, written commun., 1981) was used to calculate the dissolved oxygen at saturation:

where

$$
\ln D O_{\text {sat }}=A_{1}+A_{2} \frac{100}{T}+A_{3} \ln \frac{T}{100}+A_{4} \frac{T}{100}+S\left[B_{1}+B_{2} \frac{T}{100}+B_{3}\left(\frac{T}{100}\right)^{2}\right],
$$

$$
\begin{array}{ll}
\ln & =\text { natural logarithm; } \\
D O_{\text {sat }} & =\text { dissolved oxygen at saturation; } \\
A_{1} \quad=173.4292 & \\
A_{2} \quad=249.6339 ; \\
A_{3} \quad=143.3483 \\
A_{4} \quad=21.8492 \\
B_{1} \quad=0.033096 \\
B_{2} \quad=0.014259 \\
B_{3} \quad=0.001700 ; \\
T \quad=\text { temperature, in degrees Kelvin; and } \\
S \quad=\text { salinity, in grams per kilogram. }
\end{array}
$$

The concentration of total hardness, expressed as calcium carbonate in milligrams per liter $\left(\mathrm{mg} / \mathrm{L}\right.$ as $\left.\mathrm{CaCO}_{3}\right)$, was calculated as follows:

$$
\text { Total hardness }=2.497[\mathrm{Ca}]+4.118[\mathrm{Mg}] \text {, }
$$

where

$\mathrm{Ca}$ is the dissolved calcium concentration, in milligrams per liter, and $\mathrm{Mg}$ is the dissolved magnesium concentration, in milligrams per liter.

Some total organic carbon concentrations were calculated as the sum of the dissolved and particulate organic carbon concentrations; all are expressed as carbon in milligrams per liter $(\mathrm{mg} / \mathrm{L}$ as $\mathrm{C})$. The concentration of total nitrogen was calculated as the sum of the total nitrate plus nitrite and total ammonia plus organic nitrogen concentrations; all are expressed as nitrogen in milligrams per liter $(\mathrm{mg} / \mathrm{L}$ as $\mathrm{N})$.

Estimated loads were calculated for each of 16 constituents (no loads were calculated for the fraction of dissolved oxygen at saturation or fecal coliform bacteria) by multiplying the concentration by the instantaneous streamflow and applying unit conversions to yield an instream load in pounds per day, as follows:

$$
\begin{gathered}
\text { load }(\mathrm{lb} / \mathrm{d})=\text { concentration }(\mathrm{mg} / \mathrm{L}) \times \text { streamflow }\left(\mathrm{ft}^{3} / \mathrm{s}\right) \times 2.20462 \times 10^{-6} \mathrm{lb} / \mathrm{mg} \\
\times 86,400 \mathrm{~s} / \mathrm{d} \times 28.316 \mathrm{~L}^{-\mathrm{ft}^{3}} .
\end{gathered}
$$

When concentrations are in micrograms per liter, the conversion is

$$
\begin{gathered}
\text { load }(\mathrm{lb} / \mathrm{d})=\text { concentration }(\mu \mathrm{g} / \mathrm{L}) \times \text { streamflow }\left(\mathrm{ft}^{3} / \mathrm{s}\right) \times 2.20462 \times 10^{-9} \mathrm{lb} / \mu \mathrm{g} \\
\times 86,400 \mathrm{~s} / \mathrm{d} \times 28.316 \mathrm{~L}_{\mathrm{ft}^{3}} .
\end{gathered}
$$


Steps were taken to ensure consistent data quality because of the long time period over which the data were collected. Water-quality data for the period of record, water years 1976 to 1993, were reviewed to identify any obvious data inconsistencies (that is, data outliers) because of changes in laboratory remark codes, reporting levels, analytical methods, project data entry protocols, project data-quality review protocols, sample preservation, and sample processing. Many of these factors were known to have changed over the 18-year period of record; this may have affected the quality of the data (in this study, only data outliers were of concern). Breidt and others (1991) reported finding similar water-quality-data anomalies in this period of record. This review resulted in the removal from the data base of less than 1 percent of the original data set. Most of the corrections (removal) were for field measurements made prior to 1985 and for data that had been entered into the data base manually from paper records.

No attempt was made to identify data-biasing effects on the median values. The data review was performed prior to statistical analysis and interpretation. Data in the 0.025 and 0.975 percentiles for each station were candidates for being data outliers. In addition, plots of constituent concentrations by month, as well as constituent concentrations as a function of streamflow, were visually inspected for potential outliers. Data were evaluated by month of sample collection to determine whether a value was a seasonal outlier, and by discharge to determine whether the value was an outlier because it was affected by dilution during high flow. In addition, changes in laboratory reporting remark codes and censoring limits were reviewed. The analytical method used for the years in which the censored data were collected was determined from tables reported by Friedman and Fishman (1989) and Fishman and others (1994), and the analytical method lower-reporting limit was checked against those reported for that analytical method in Skougstad and others (1979), Fishman and Friedman (1989), and Wershaw and others (1987). The outliers were evaluated by considering:

(1) concentrations of related constituents in the same sample,

(2) the constituent concentration at sites upstream or downstream,

(3) the effects of an early or late change of season,

(4) the number of measurements for the month or season,

(5) the presence of point-source discharges upstream from the sampling site,

(6) the possibility of constituent inputs from seasonal nonpoint-source runoff,

(7) streamflow regulation,

(8) the streamflow discharge, and

(9) surrounding geology and physiographic province.

Outliers were deleted only if no plausible explanation based on the factors listed above was found.

\section{Streamflow Data}

Instantaneous-streamflow values were used when available to calculate instream loads; when those values were not available, an estimated daily mean was used. Continuous streamflow records from gages were available for 18 water-quality stations and were used to determine instantaneous streamflows. For the 10 stations with no streamflow data, a correlation with an adjacent gaging station was developed, and a mean daily streamflow was estimated from the correlation. 
As with the water-quality data, steps were taken to ensure consistent data quality because of the long time period over which the data were collected. Streamflow data for the period of record, water years 1976 to 1993, were reviewed to identify any obvious data inconsistencies (that is, data outliers), many of which were due to data entry errors. The review was performed prior to statistical analysis and interpretation. This review resulted in the removal from the data base of less than 2 percent of the original data set.

Streamflow data from each surface-water-quality monitoring station were regressed on daily mean values from the NWIS data base to ensure that the values were consistent. Residuals of plots of streamflow as a function of gage height, and streamflow at adjacent or nearby continuous-record stations, were evaluated. Outliers were identified as those values with studentized residuals larger than an absolute value of 2 and were further evaluated by considering:

(1) the time of sample collection,

(2) upstream flow regulation, and

(3) streamflow at nearby stations.

If no plausible explanation for the apparent inconsistency of a data point (an outlier), based on the factors listed above, was found, the daily mean values were used. These new values were double-checked by plotting them on a graph of field specific conductance as a function of flow duration. Specific conductance would be expected to be inversely proportional to streamflow, except during times of snow melt. The measurement of specific conductance is independent of the measurement of streamflow.

\section{Flow-Duration Data}

Flow durations for each water-quality station were obtained as data from WATSTORE (National Water Data Storage and Retrieval System), as output from computer simulation using MOVE.1 (Maintenance of Variance Extension, Type 1) (Hirsch, 1982), and as drainage area adjustments from nearby surface-water gaging stations (table 3 ).

Flow-duration tables were developed by using the Daily Value Statistics (DVSTAT) computer program in the WATSTORE data base for 19 of the 28 surface-water-quality stations that had continuous streamflow records. Flow-duration data show the percentage of time that a particular discharge is exceeded, and a flow-duration point is a discharge value, in $\mathrm{ft}^{3} / \mathrm{s}$, interpolated from a duration table for a particular percentage of time. For the purpose of this study, the 25 percent duration point was used to determine high-flow conditions, and the 75 percent duration point was used to determine the low-flow conditions. The resulting values for each surface-water-quality station are shown in table 3.

Base-flow relations were determined for 8 of the 28 water-quality gaging stations by correlating instantaneous low-flow discharge at the partial-record station with the mean daily discharge at a nearby "index" continuous-record gaging station. A streamflow record extension technique, MOVE.1, was used to develop the correlations (Hirsch, 1982). MOVE.1 was used because it was adequate for the purposes of this study, in which flow duration was used only to divide streamflow data into groups of high, moderate, and low ranges for trend analysis. The relations are made in the following form: 


$$
L Q_{P R}=u_{P R}+\left(\frac{S_{P R}}{S_{C R}}\right)\left[L Q_{C R}-u_{C R}\right]
$$

where

$L Q_{P R}=$ the base-10 logarithm of the partial-record streamflow,

$u_{P R} \quad=$ the mean of the logarithms of partial-record streamflow,

$S_{P R} \quad=$ the standard deviation of logarithms of partial-record streamflow,

$L Q_{C R}=$ the base-10 logarithm of the index continuous-record streamflow,

$u_{C R}=$ the mean of the logarithms of the index continuous-record streamflows, and

$S_{C R} \quad=$ the standard deviation of logarithms of the index continuous-record streamflow.

The flow-duration value for partial-record station 01409815, West Branch Wading River at Maxwell, New Jersey, was estimated using drainage area adjustments from nearby surfacewater gaging stations (table 3 ).

\section{$\underline{\text { Statistical Methods }}$}

Concentration measurements were selected only if they had an associated, nonzero value of streamflow (instantaneous or estimated); only one observation per constituent per day was used. Concentration values were reported as "uncensored," "less-than," and "greater-than". Concentrations of constituents other than fecal coliform bacteria were either uncensored or lessthan values; some measurements of fecal coliform bacteria were greater-than values.

Median concentrations and relations of surface-water quality to streamflow were determined for each constituent and station. The following types of relations of surface-water quality to streamflow are presented graphically by constituent for each station in appendixes 1-18: concentration to streamflow, load to streamflow, and trends in concentrations during low and high flows.

\section{Calculation of Medians}

Medians were calculated for measurements made during two periods - the entire period of study (water years 1976-93) and the last 5 years of the period of study (water years 1989-93). The method of calculation depended upon whether the data set contained censored values. For data sets with only uncensored data, the values were ranked, and the median was calculated as the 50th percentile. For data sets with less-than values but no greater-than values, medians were calculated by using the adjusted maximum likelihood method (AMLE) described in Cohn (1988) and Helsel and Cohn (1988). If the data set contained either an insufficient number of observations for this method or greater-than values, the median was determined by manually ranking and identifying the 50th percentile value. 
Table 3. Estimated flow-duration values of mean daily discharge and data source for surfacewater-quality stations in the Atlantic Coastal, lower Delaware River, and Delaware Bay Basins, N.J.

$\left[\mathrm{ft}^{3} / \mathrm{s}\right.$, cubic feet per second; $\%$, percent; WATSTORE, National Water Data Storage and Retrieval System; MOVE.1, Maintenance of Variance Extension, Type 1; Drainage Area, adjusted on basis of drainage area from nearby surface-water gages]

\begin{tabular}{|c|c|c|c|}
\hline \multirow[b]{2}{*}{ Station number } & \multicolumn{2}{|c|}{$\begin{array}{l}\text { Flow duration values of mean daily discharge, } \\
\text { in } \mathrm{ft}^{3} / \mathrm{s}\end{array}$} & \multirow[b]{2}{*}{ Source } \\
\hline & $25 \%$ & $75 \%$ & \\
\hline 01408000 & 83.9 & 36.5 & WATSTORE \\
\hline 01408500 & 261 & 131 & WATSTORE \\
\hline 01409387 & 68.0 & 24.8 & MOVE.1 \\
\hline 01409416 & 26.2 & 9.1 & MOVE.1 \\
\hline 01409500 & 144 & 74.0 & WATSTORE \\
\hline 01409815 & 177 & 70.3 & Drainage Area \\
\hline 01410000 & 104 & 49.9 & WATSTORE \\
\hline 01410150 & 18.9 & 10.2 & WATSTORE \\
\hline 01410784 & 22.2 & 7.2 & MOVE.1 \\
\hline 01411000 & 106 & 50.6 & WATSTORE \\
\hline 01411110 & 322 & 143 & MOVE.1 \\
\hline 01411500 & 211 & 96.2 & WATSTORE \\
\hline 01411800 & 361 & 149 & WATSTORE \\
\hline 01412800 & 38.0 & 22.5 & WATSTORE \\
\hline 01463620 & 66.1 & 21.9 & WATSTORE \\
\hline 01464000 & 155 & 51.6 & WATSTORE \\
\hline 01464500 & 145 & 61.3 & WATSTORE \\
\hline 01464515 & 38.3 & 9.8 & MOVE.1 \\
\hline 01465850 & 120 & 39.8 & WATSTORE \\
\hline 01466500 & 2.7 & 1.4 & WATSTORE \\
\hline 01467000 & 213 & 90.5 & WATSTORE \\
\hline 01467069 & 46.9 & 8.9 & MOVE.1 \\
\hline 01467081 & 16.2 & 6.8 & WATSTORE \\
\hline 01467150 & 33.4 & 17.4 & WATSTORE \\
\hline 01467329 & 34.1 & 18.3 & MOVE.1 \\
\hline 01477120 & 44.0 & 20.3 & WATSTORE \\
\hline 01477510 & 43.4 & 14.7 & MOVE.1 \\
\hline 01482500 & 19.9 & 7.2 & WATSTORE \\
\hline
\end{tabular}




\section{Determination of Relations of Surface-Water Quality to Streamflow}

The processes used to determine relations between concentration and streamflow and load and streamflow, and trends in concentrations during high and low flows are described in this section.

\section{$\underline{\text { Relations of concentration to streamflow }}$}

Water quality is strongly influenced by biological activity, which is seasonal; therefore, relations between concentration and streamflow were developed by using (1) all measurements, (2) growing-season measurements only, and (3) nongrowing-season measurements only. The growing season in New Jersey is from April 1 through October 31; the nongrowing season is from November 1 through March 31. The dates for the growing and nongrowing seasons were based on the average times of the first and final frosts in New Jersey (Ruffner and Bair, 1977). All relations take the following form:

$$
\log (C O N C)=S L O P E \times \log (F L O W)+I N T,
$$

where

$$
\begin{aligned}
& \log =\text { base-10 logarithm; } \\
& C O N C=\text { constituent concentration, in indicated units; } \\
& \text { SLOPE }=\text { the slope of the relation; } \\
& \text { FLOW }=\text { streamflow, in cubic feet per second; and } \\
& I N T \quad=\text { the intercept of the relation. }
\end{aligned}
$$

These relations were developed by using Tobit regression (Cohn, 1988), which includes less-than values. For Tobit regression in this report, greater-than values were considered to be uncensored. Where there were no less-than values, this method resulted in the same values of SLOPE and INT as those calculated by ordinary least-squares regression. A goodness-of-fit value such as the correlation coefficient is not presented; the Tobit method does not result in such a value.

A relation of water quality to streamflow at a given station was developed only if at least nine uncensored concentration values were available. T.A. Cohn (U.S. Geological Survey, written commun., 1995) noted that at least nine uncensored values were needed to use the Tobit method with two unknowns. Nine uncensored values were sometimes insufficient data from which to calculate statistically significant results.

A relation using all measurements is reported only if the value of SLOPE was different from zero at the 0.05 level of significance; otherwise, a SLOPE of " 0 " is reported. A "not determined" value of SLOPE is reported if the data were insufficient to conduct the analysis. A value of INT was calculated only if the value of SLOPE was different from zero. 
Each set of seasonal relations was developed and reported by using the methods just described if an analysis of covariance (described below) indicated that the seasonal relations were different from one another at the 0.05 level of significance. The analysis of covariance was conducted only if there were at least nine uncensored measurements during each season.

The analysis of covariance followed the approach in Helsel and Hirsch (1992), except that Tobit regression was used in place of ordinary least-squares regression. The analysis determined whether a complex model with a seasonal component was significantly better than a simple model without a seasonal component. The simple model is given in equation 7; the complex model is given in equation 8 .

$$
\log (C O N C)=\left[S L O P E_{1} \times \log (F L O W)+I N T_{1}\right]+\left[S L O P E_{2} \times \log (F L O W)+I N T_{2} \times I\right]
$$

where

$\log =$ base-10 logarithm;

CONC = constituent concentration, in indicated units;

$F L O W=$ streamflow, in cubic feet per second;

$I \quad=$ an index for season $(\mathrm{I}=0$ for the nongrowing season, and $\mathrm{I}=1$ for the growing season);

$S L O P E_{1}=$ the slope for the nongrowing season;

$I N T_{1}=$ the intercept for the nongrowing season;

$S L O P E_{2}=$ the difference between the growing- and nongrowing-season slopes; and

$I N T_{2}=$ the difference between the growing- and nongrowing-season intercepts.

A test statistic different from that used by Helsel and Hirsch (1992) was calculated because of the use of Tobit regression in the analysis of covariance (T.A. Cohn, written commun., 1995). The value, $X$, was determined from the results of the simple and complex models, then compared to the value of the chi-square distribution with 2 degrees of freedom and a 0.05 level of significance. If the value of $\mathrm{X}$ equalled or exceeded the corresponding value of chi-square distribution, the seasonal relations differed from one another in SLOPE or INT or both. Whether SLOPE was different or INT was different was not determined. The value of $\mathrm{X}$ was calculated as follows:

$$
X=-2 \times \ln \left[\left(L K H D_{S}\right) /\left(L K H D_{C}\right)\right],
$$

where

$$
\begin{array}{ll}
X & =\text { the test statistic, } \\
\ln & =\text { natural logarithm, } \\
L K H D_{S} & =\text { the likelihood of the simple relation, and } \\
L K H D_{C} & =\text { the likelihood of the complex relation. }
\end{array}
$$

The detection level of each constituent at each station is required to conduct Tobit regression. The detection limits for constituents with only uncensored values were determined by considering the method of analysis and the smallest concentration measured at all stations. These values (table 4) are either equal to the smallest less-than value or slightly less than the smallest uncensored value measured at all stations during water years 1976-93. 
Table 4. Estimated detection limits for selected constituents measured in the Atlantic Coastal, lower Delaware River, and Delaware Bay Basins, N.J., water years 1976-93

[mg/L, milligrams per liter; $\mathrm{CaCO}_{3}$, calcium carbonate; $\mathrm{C}$, carbon; $\mathrm{Na}$, sodium; $\mathrm{Cl}$, chloride; $\%$, percent; $\mathrm{P}$, phosphorus; $\mathrm{N}$, nitrogen; $\mu \mathrm{g} / \mathrm{L}$, micrograms per liter; $\mathrm{B}$, boron; $\mathrm{Pb}$, lead;

MPN/100 mL, most probable number per 100 milliliters.]

Alkalinity, $\mathrm{mg} / \mathrm{L}$ as $\mathrm{CaCO}_{3}$

Hardness, $\mathrm{mg} / \mathrm{L}$ as $\mathrm{CaCO}_{3} \quad 10$

Total organic carbon, $\mathrm{mg} / \mathrm{L}$ as $\mathrm{C} \quad .2$

Suspended sediment, $\mathrm{mg} / \mathrm{L} \quad 1$

$\begin{array}{ll}\text { Dissolved solids, } \mathrm{mg} / \mathrm{L} & 10\end{array}$

Dissolved sodium, $\mathrm{mg} / \mathrm{L}$ as $\mathrm{Na} \quad 1$

Dissolved chloride, $\mathrm{mg} / \mathrm{L}$ as $\mathrm{Cl}$

Dissolved oxygen, $\mathrm{mg} / \mathrm{L} \quad ~ .5$

Fraction of dissolved oxygen at saturation, \% 5

$\begin{array}{ll}\text { Total phosphorus, } \mathrm{mg} / \mathrm{L} \text { as } \mathrm{P} & .01\end{array}$

Total nitrogen, $\mathrm{mg} / \mathrm{L}$ as $\mathrm{N} \quad 1$

$\begin{array}{ll}\text { Total nitrate plus nitrite, } \mathrm{mg} / \mathrm{L} \text { as } \mathrm{N} & .05\end{array}$

$\begin{array}{ll}\text { Total nitrite, } \mathrm{mg} / \mathrm{L} \text { as } \mathrm{N} & .002\end{array}$

Total ammonia plus total organic nitrogen, $\mathrm{mg} / \mathrm{L}$ as $\mathrm{N} \quad .03$

Total ammonia, $\mathrm{mg} / \mathrm{L}$ as $\mathrm{N} \quad .01$

$\begin{array}{ll}\text { Total boron, } \mathrm{mg} / \mathrm{L} \text { as B } & 10\end{array}$

Total lead, mg/L as $\mathrm{Pb} \quad 1$

Fecal coliform bacteria, MPN/100 mL 2 


\section{$\underline{\text { Relations of load to streamflow }}$}

The relation of load to streamflow was developed by using the same procedures as those used to develop the relation of concentration to streamflow for all measurements. Loads were not determined for fraction of dissolved oxygen at saturation and fecal coliform bacteria. For each constituent and station, the detection limit was set equal to the smallest uncensored load measured at the station. The load relation takes the following form:

$$
\log (L O A D)=S L O P E \times \log (F L O W)+I N T,
$$

where

$$
\begin{aligned}
& \log \quad=\text { base-10 logarithm; } \\
& L O A D=\text { constituent load, in pounds per day; } \\
& \text { SLOPE }=\text { the slope of the relation; } \\
& F L O W=\text { streamflow, in cubic feet per second; and } \\
& I N T \quad=\text { the intercept of the relation. }
\end{aligned}
$$

A smoothed relation of load to streamflow is shown for a constituent at each station at which there were 10 or more values. This relation was determined by using the SM smoothing routine in SAS (SAS Institute, Inc., 1990, p. 416).

\section{Trends in concentrations during low and high flows}

Trends in concentrations during low and high flows were tested to determine whether the probability distribution from which the observations come increased or decreased during water years 1976-93. The 75-percent and 25-percent values of the flow durations were used to divide the measurements for each station into a low- or high-flow group, respectively. Concentrations during low flows were designated as those measured at streamflows less than or equal to the daily mean streamflow that was exceeded 75 percent of the time; concentrations during high flows were designated as those measured at streamflows greater than the daily mean streamflow that was exceeded 25 percent of the time.

For both the low- and high-flow data sets, trend tests were conducted only if there was at least one measurement in each data set consisting of not less than four of the six water years in each one-third of the period of study (18 years). This requirement followed a recommendation made in Helsel and Hirsch (1992) that there be no less than 20 percent of the total measurements in each one-third of the period being tested for trends. Therefore, 12 was the minimum number of low- or high-flow measurements used in a test. Fewer data could have been tested for trends. The fewer the data, however, the less likely it is that the measured concentrations represent conditions during the period tested and, therefore, the less likely that the results of the trend test are accurate.

The seasonal Kendall's tau method (Hirsch and others, 1982) was used to examine the data for trends. For both the low- and high-flow data sets, the test was run on the median of the measured concentrations for each water year because of variations in sampling frequency (Hirsch and others, 1982). The test statistic, tau, was calculated from the relative sizes of the annual 
median concentrations, then tested to see whether it was significantly different from zero. For this report, a trend is indicated if the value of tau was significantly different from zero at the 0.05 level. Seasonality was not included in the test.

A value of SLOPE is reported for constituent concentrations during either low or high flows if a trend was indicated. The value of SLOPE is the median of the slopes of all pairs of annual median concentrations. A SLOPE value of " 0 " is reported if sufficient data were available for a trend test, but a trend was not indicated; a "not determined" value is reported if there were insufficient data for a test. The units of SLOPE are units of concentration per year.

No value is reported for the intercept of the relation showing the trend of concentration over time. An intercept value is calculated by the trend test only for the purpose of showing the trend in a plot.

Multiple trend tests were conducted on data sets with censored values; the censored values were set at their minimum and maximum possible values. Two tests were conducted on data sets with less-than values but no greater-than values - one with the less-than values set to the reporting limit and one with the less-than values set to zero. Two tests were conducted on data sets with greater-than values but no less-than values-one with the greater-than values set to the reporting limit and one with the greater-than values set to $10^{7}$ (a value greater than all reported uncensored values). Four tests were conducted on data sets with both less-than and greater-than values-one with each of the permutations of the greater-than and less-than values discussed above.

For each data set with censored values, the results are reported only for the trend relation with the least significant value for tau. Because of the uncertainty of the censored data, a significant trend slope is reported only if a slope is determined when the censored data are set equal to both their minimum and maximum values.

\section{RELATIONS OF SURFACE-WATER QUALITY TO STREAMFLOW}

An understanding of the relation of surface-water quality to streamflow is important for assessment of the relative contributions of point sources, ground water, and storm runoff to instream loads. Point sources (permitted discharges) release constituents to a stream at a relatively constant rate, independent of the receiving streamflow conditions. Ground-water contributions to a stream are somewhat constant, although they vary slightly with season and precipitation rate. Storm runoff contributions to a stream are intermittent, depending on storm intensity and frequency, and occur only during high flows. Instream constituent concentrations are a summation of the contributions from these constant (point source and ground water) and intermittent (storm runoff) sources (Buxton and others, 1998).

To describe the relation of surface-water quality to streamflow, the data analyses are presented in three ways. First, three aspects of the relation of surface-water quality to streamflow (concentration to streamflow, load to streamflow, and trends in concentrations during low and high flows) are presented graphically by constituent for each station in appendixes 1-18. Second, the data analyses are presented by basin in the text; tables for each station list the median concentrations, the regression slopes of concentration and load to streamflow, and the directions 
of the trends in concentrations during low and high flows for all constituents along with the AMNET impairment status at and near the station. Third, relations are presented in schematics showing the regional trends in concentrations during low and high flows and the slopes of load to streamflow by constituent.

Appendixes 1-18 illustrate the relations of surface-water quality to streamflow by constituent for each station with three graphs. Figure 7 is an example page from appendix 12. The first graph shows the relation of concentration to streamflow. Plots of concentration to streamflow indicate how instream constituent concentrations vary with streamflow, but do not indicate the relative contributions of constant and intermittent sources. Data for stations on streams that drain developed areas show the most scatter, especially for inorganic constituents such as sodium, chloride, and hardness. Relations between concentration and streamflow were developed by using (1) all measurements, (2) only measurements collected during the growing season, and (3) only measurements collected during the nongrowing season. Growing-season measurements are shown with open symbols and nongrowing-season measurements are shown with crisscross symbols. Different symbols are used to show uncensored and censored values. For each group of measurements, the number of observations and values of slope and intercept are listed, and a regression line is shown when the slope of concentration to streamflow is different from zero at the 0.05 significance level. A seasonal dependency is indicated when the relations of concentration to streamflow for the growing- and nongrowing-season measurements are different. The 75 and 25 percentiles of the flow duration also are indicated.

The second graph in figure 7 shows the relation of load to streamflow. The regression slope of load to streamflow indicates the relative contributions of constant and intermittent sources to the instream load. The steeper the slope, the greater the contribution during increased streamflow from storm runoff (intermittent sources). Relations between load and streamflow were developed using all measurements. Different symbols are used to show uncensored and censored values. The number of observations and values of slope and intercept are shown, and a regression line is drawn when the slope is different from zero at the 0.05 significance level. A smoothed relation between load and streamflow is shown when there are 10 or more observations. The 75 and 25 percentiles of the flow duration also are indicated.

The third graph in figure 7 shows the trends in concentrations during low and high flows. Trends in constituent concentrations during high and low flows can indicate changes over time in the contributions from intermittent and constant sources, respectively. Positive trends during high flows indicate an increase in the storm runoff contributions over time, whereas negative trends indicate a decrease in the storm runoff contributions. Positive trends during low flows indicate an increase in the contributions from point sources and ground water over time, whereas negative trends indicate a decrease in the contributions from point sources and ground water. Measurements during low flows are shown with open symbols, and measurements during high flows is shown with crisscross symbols. Different symbols are used to show uncensored and censored values. The number of observations and water years during which at least one measurement was made is shown for each group of measurements. Trends are indicated by regression lines and slope values when the seasonal Kendall tau value is significant. 
APPENDIX 12. Relations of constituent concentration and load to streamflow and trends in concentration with time

TOTAL NITRATE PLUS NITRITE

01465850 SOUTH BRANCH RANCOCAS CREEK AT VINCENTOWN, N.J.

[NVALUES, number of values; LOG, base-10 logarithm; CONC, concentration in indicated units; INT, intercept; FLOW, streamflow in cubic feet per second; NWYS, number of water years during which at least one measurement was made; a slope value of '0' indicates that the slope is not significantly different from zero; ND, not determined; $\mathrm{CaCO}$, calcium carbonate; C, carbon; $\mathrm{N}$, nitrogen; $\mathrm{P}$, phosphorus; $\mathrm{Pb}$, lead; $\mathrm{B}$, boron; $\mathrm{Cl}$, chloride; $\mathrm{Na}$, sodium; MOST PROBABLE NUMBER INDEX is per 100 milliliters]

RELATION OF CONCENTRATION TO STREAMFLOW
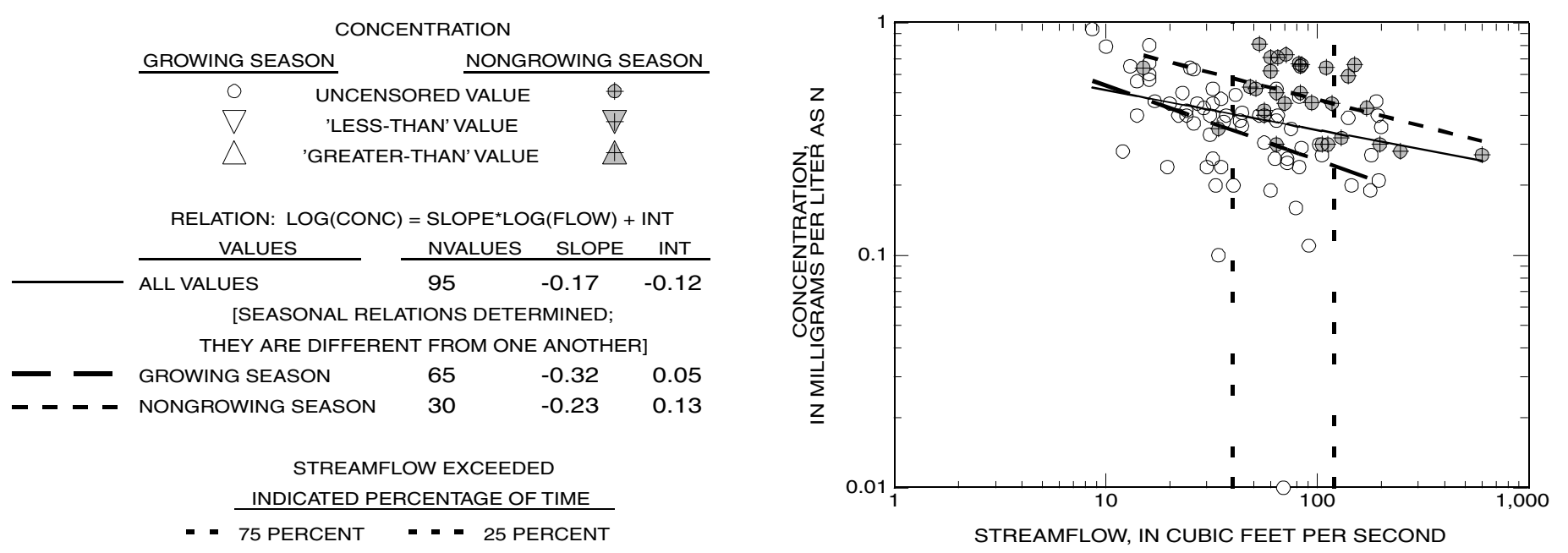

RELATION OF LOAD TO STREAMFLOW

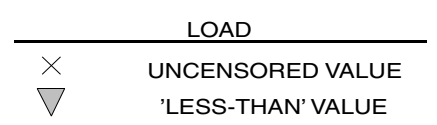

RELATION: LOG(LOAD) $=$ SLOPE*LOG(FLOW $)+$ INT

\begin{tabular}{llccc} 
VALUES & & NVALUES & SLOPE & INT \\
\cline { 1 - 2 } \cline { 5 - 5 } & 95 & 0.83 & 0.61
\end{tabular}

SMOOTHED RELATION BETWEEN LOAD AND FLOW (SHOWN IF THERE ARE 10 OR MORE VALUES)

$$
\begin{gathered}
\text { STREAMFLOW EXCEEDED } \\
\text { - - } 75 \text { PERCENT - - - } 25 \text { PERCENT }
\end{gathered}
$$

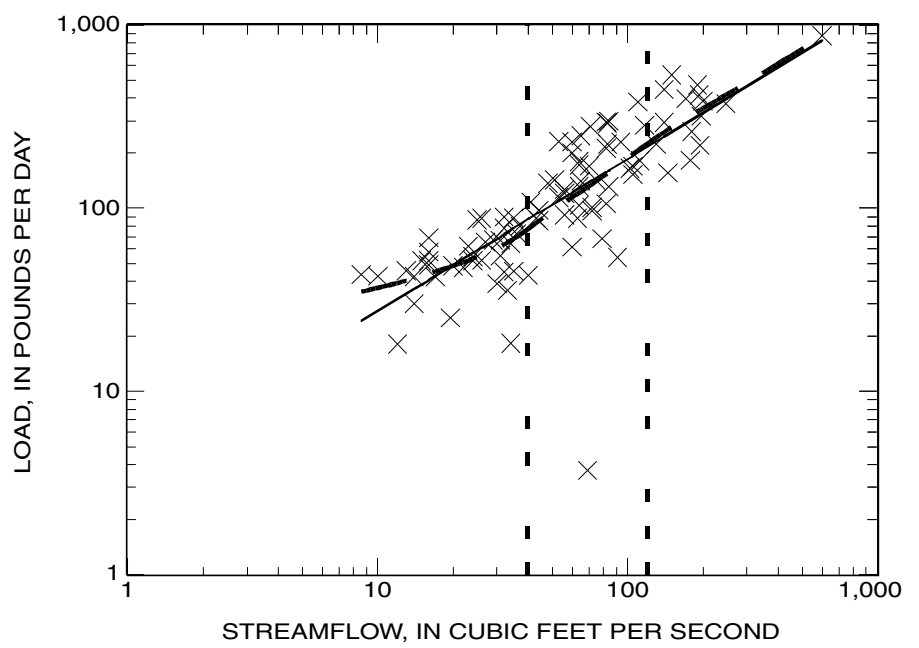

TRENDS IN LOW- AND HIGH-FLOW CONCENTRATIONS

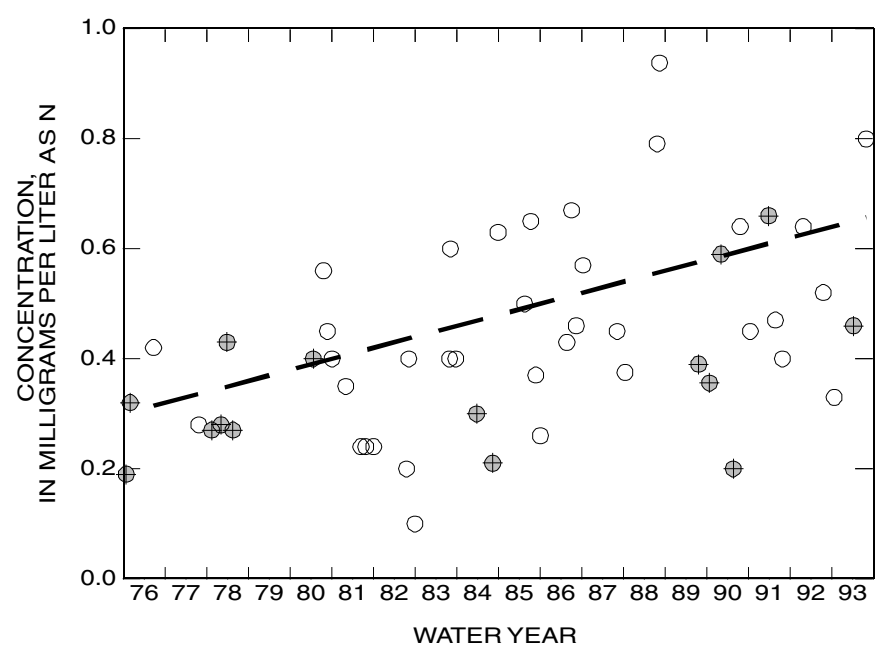

Figure 7. Example page from Appendix 12 of graphs showing relation of concentration to streamflow, relation of load to streamflow, and trends in low- and high-flow concentrations for total nitrate plus nitrite at a station on the South Branch Rancocas Creek at Vincentown, New Jersey, for water years 1976-93. (Available on CD ROM) 


\section{Analysis of Relations by Basin}

Median concentrations, regression slopes of concentration and load to streamflow, and directions of the trends in concentrations during low and high flows for each constituent are presented in tables 5 through 32. Constituents that show seasonal dependency (the relations of concentration to streamflow for the growing and nongrowing seasons are different) and the 1993 AMNET impairment status in the vicinity (at and within five miles upstream and downstream) of the surface-water-quality station also are listed. Median concentrations were calculated for two periods, the entire period of study (water years 1976-93) and the last five years of the period of study (water years 1989-93) to provide a visual comparison of water quality to the AMNET impairment status. In tables 5 through 32, the directions of trends in concentrations during low and high flows are represented by,,+- 0 , and NA symbols. Results of statistical tests are discussed for each river basin. One- to four-letter abbreviations are used for each water-quality constituent throughout the discussion. (See Conversions Factors and Abbreviated Water-Quality Units, p. xii.)

Slopes of load to streamflow for each constituent are divided into three ranges in order to describe the relative contributions of constant (point source and ground water) and intermittent (storm runoff) sources to instream load. High-range slopes are greater than or equal to 75 percent of the interval between the minimum and maximum slopes. For stations with slopes in the high range, a larger contribution from storm runoff to instream load occurs than at other sites, indicating an increased relative importance of nonpoint sources at these sites. Moderate-range slopes are greater than 25 percent and less than 75 percent of the interval between the minimum and maximum slopes. Low-range slopes are less than or equal to 25 percent of the interval between the minimum and maximum slopes. For stations with slopes in the low range, a smaller contribution from storm runoff to instream load occurs than at other sites, indicating an increased relative importance of continuous sources at these sites. For constituents with large slopes of load to streamflow (greater than 0.8), however, storm runoff is most likely the more significant contributor to instream loads, even for stations with load slopes in the low range. Only load slopes in the high and low ranges are discussed.

In 1992, the Bureau of Water Monitoring of the NJDEP reactivated the AMNET to monitor benthic-macroinvertebrate populations at more than 700 stations in the major drainage basins in New Jersey. The objective of this biomonitoring program is to provide long-term, basinwide, biological data for surface water (New Jersey Department of Environmental Protection, 1996a and 1996b). Stations will be monitored every 5 to 6 years, a realistic temporal lag between the cessation and recovery of a biological community from a perturbation. Biomonitoring uses instream populations of benthic macroinvertebrates as indicators of the quality of the surface water. Species of the instream macroinvertebrate community occupy distinct niches based on their tolerance to environmental conditions; these communities can change as environmental conditions change. Benthic-community biological impairment is indicated by (1) the absence of contaminant-sensitive macroinvertebrate taxa, (2) excessive dominance by certain taxon, (3) low overall taxa richness, or (4) perceptible shifts in community structure relative to a reference condition. 
The NJDEP sampling techniques and biometric assessments were modified from U.S. Environmental Protection Agency protocols to integrate community, population, and functional parameters into one easily understood evaluation of biological integrity (New Jersey Department of Environmental Protection, 1996a and 1996b). The integrated assessment results at each station were given an AMNET impairment status rating of non-impaired-the benthic community is comparable to communities found in other undisturbed streams within the region and is characterized by a maximum taxa richness, balanced taxa groups, and good representation of intolerant individuals; moderately impaired - the macroinvertebrate richness and community balance are reduced and intolerant taxa are absent because of taxa composition changes; or severely impaired - the benthic community has dramatically changed and macroinvertebrates are dominated by a few tolerant taxa. When used together with chemical and physical monitoring, benthic macroinvertebrate monitoring is a good indicator of stream quality and possible sources of impairment.

\section{Atlantic Coastal Basin}

Eleven water-quality stations are located in four subbasins in the Atlantic Coastal Basin. One station is located on each of the Manasquan and Toms Rivers. Six stations are located in the Mullica River Basin — one on the main stem of the Mullica and one on each of the Hammonton Creek; Batsto River; Oswego River; West Branch of the Wading River, a tributary to the Oswego River; and the East Branch of the Bass River. Three stations are located on the main stem of the Great Egg Harbor River.

\section{Manasquan River}

For the one station on the Manasquan River, station 01408000 at Squankum, the 5-year medians are smaller than the period-of-record medians for TOC, TP, TN, NO32, NO2, TAON, NH4, and BACT; 5-year and period-of-record medians are similar for all other constituents (table 5a). The regression slopes of concentration to streamflow for DO, FDO, TP, TN, NO2, NH4, and BACT show seasonal dependency. The regression slopes of load to streamflow are in the high range for SS, TP, TN, and NH4, indicating greater contributions of these constituents from surface runoff relative to that at other sites in the study area. The load slopes for SS and NH4 at this site are the largest for these constituents in the study area. The load slopes are in the low range for HARD, indicating smaller contributions of this constituent from storm runoff relative to that at other sites in the study area. The load slope for HARD is the smallest for HARD in the study area. During low flows, the trend is positive for DO and FDO and insignificant for BACT. The trend is negative for TAON during low flow, indicating a decrease in the contributions of TAON from point sources and ground water over time. Insufficient data are available to determine trends for all other constituents during low flow and for all constituents during high flows. The AMNET impairment status is moderately impaired at, and upstream and downstream from, station 01408000 (table 5b). 
Table 5a. Median concentrations, relations of concentration and load to streamflow, and directions of concentration trends for selected waterquality constituents at water-quality station 01408000, Manasquan River at Squankum, N.J.

[Number in parenthesis is the number of available data values; WY, water years; $\mathrm{mg} / \mathrm{L}$, milligrams per liter; $\mathrm{CaCO}_{3}$, calcium carbonate; $\mathrm{C}$, carbon; Na, sodium; $\mathrm{Cl}$, chloride; \%, percent; $\mathrm{P}$, phosphorus; $\mathrm{N}$, nitrogen; $\mu \mathrm{g} / \mathrm{L}$, micrograms per liter; $\mathrm{B}$, boron; $\mathrm{Pb}$, lead; MPN/100 mL, most probable number per 100 milliliters. Regression slopes and trend directions are zero when the slope is not different from zero at the 0.05 significance level; * indicates seasonal dependency (the slope and (or) intercept of growing (April through October) and non-growing (November through March) season data were different at the 0.05 significance level); +, positive trend direction; -, negative trend direction; NA, insufficient data for analysis; ND, undetermined value]

\begin{tabular}{|c|c|c|c|c|c|c|c|c|c|}
\hline \multirow{3}{*}{$\begin{array}{c}\text { Constituent } \\
\text { nity, } \mathrm{mg} / \mathrm{L} \text { as } \mathrm{CaCO}_{3}\end{array}$} & \multirow{2}{*}{\multicolumn{2}{|c|}{$\begin{array}{c}\text { 1989-93 WY } \\
\text { Median } \\
\text { concentration }\end{array}$}} & \multicolumn{7}{|c|}{ 1976-93 WY } \\
\hline & & & \multicolumn{2}{|c|}{$\begin{array}{l}\text { Median } \\
\text { concentration }\end{array}$} & \multicolumn{2}{|c|}{$\begin{array}{c}\text { Regression } \\
\text { slope of } \\
\text { concentration to } \\
\text { streamflow }\end{array}$} & \multirow{2}{*}{$\begin{array}{c}\begin{array}{c}\text { Regression } \\
\text { slope of } \\
\text { load to } \\
\text { streamflow }\end{array} \\
0.365\end{array}$} & \multirow{2}{*}{$\begin{array}{c}\begin{array}{c}\text { Low- } \\
\text { flow } \\
\text { trend } \\
\text { direction }\end{array} \\
\text { NA }\end{array}$} & \multirow{2}{*}{$\begin{array}{c}\text { High- } \\
\text { flow } \\
\text { trend } \\
\text { direction } \\
\text { NA }\end{array}$} \\
\hline & 41 & (11) & 41 & (11) & -0.635 & & & & \\
\hline Hardness, $\mathrm{mg} / \mathrm{L}$ as $\mathrm{CaCO}_{3}$ & 80 & $(12)$ & 66 & $(56)$ & -.302 & & .698 & NA & NA \\
\hline Total organic carbon, $\mathrm{mg} / \mathrm{L}$ as $\mathrm{C}$ & 1.8 & (11) & 6.8 & $(23)$ & .490 & & 1.489 & NA & NA \\
\hline Suspended sediment, $\mathrm{mg} / \mathrm{L}$ & 4 & (11) & 16 & $(28)$ & 1.318 & & 2.317 & NA & NA \\
\hline Dissolved solids, mg/L & 136 & (11) & 128 & (26) & 0 & & .923 & NA & NA \\
\hline Dissolved sodium, $\mathrm{mg} / \mathrm{L}$ as $\mathrm{Na}$ & 8 & $(12)$ & 13 & $(57)$ & 0 & & .948 & NA & NA \\
\hline Dissolved chloride, $\mathrm{mg} / \mathrm{L}$ as $\mathrm{Cl}$ & 16 & (13) & 18 & (62) & 0 & & .929 & NA & NA \\
\hline Dissolved oxygen, $\mathrm{mg} / \mathrm{L}$ & 9.3 & $(21)$ & 8.6 & (119) & 0 & $*$ & 1.001 & + & NA \\
\hline $\begin{array}{l}\text { Fraction of dissolved oxygen at } \\
\text { saturation, } \%\end{array}$ & 87 & $(20)$ & 82 & (97) & 0 & $*$ & ND & + & NA \\
\hline Total phosphorus, $\mathrm{mg} / \mathrm{L}$ as $\mathrm{P}$ & .05 & $(21)$ & .08 & $(54)$ & .447 & $*$ & 1.446 & NA & NA \\
\hline Total nitrogen, $\mathrm{mg} / \mathrm{L}$ as $\mathrm{N}$ & 1.1 & $(21)$ & 2.6 & $(105)$ & .320 & $*$ & 1.320 & NA & NA \\
\hline Total nitrate plus nitrite, $\mathrm{mg} / \mathrm{L}$ as $\mathrm{N}$ & .75 & $(21)$ & .95 & $(111)$ & 0 & & 1.159 & NA & NA \\
\hline Total nitrite, $\mathrm{mg} / \mathrm{L}$ as $\mathrm{N}$ & .007 & $(20)$ & .032 & $(107)$ & 0 & $*$ & 1.049 & NA & NA \\
\hline $\begin{array}{l}\text { Total ammonia plus organic nitrogen, } \\
\mathrm{mg} / \mathrm{L} \text { as } \mathrm{N}\end{array}$ & .27 & $(21)$ & 1.68 & (119) & .475 & & 1.475 & - & NA \\
\hline Total ammonia, $\mathrm{mg} / \mathrm{L}$ as $\mathrm{N}$ & .03 & $(21)$ & .80 & $(111)$ & .733 & $*$ & 1.732 & NA & NA \\
\hline Total boron, $\mu \mathrm{g} / \mathrm{L}$ as $\mathrm{B}$ & 25 & (4) & 25 & (4) & ND & & ND & NA & NA \\
\hline Total lead, $\mu \mathrm{g} / \mathrm{L}$ as $\mathrm{Pb}$ & $<1$ & (7) & 4 & (43) & 1.114 & & 2.114 & NA & NA \\
\hline Fecal coliform bacteria, MPN/100 ml & 80 & $(20)$ & 490 & $(121)$ & .555 & $*$ & ND & 0 & NA \\
\hline
\end{tabular}

Table 5b. 1993 AMNET impairment status in the vicinity of water-quality station 01408000, Manasquan River at Squankum, N.J.

[AMNET, Ambient Biomonitoring Network; WQ, water-quality. Upstream from WQ station is within 5 miles upstream from the WQ station; at WQ-station location is within 0.5 mile upstream or downstream from the WQ station; downstream from WQ station is within 5 miles downstream from the WQ station; ND, undetermined impairment status]

\begin{tabular}{lccc}
\hline & Upstream from WQ station & At WQ-station location & Downstream from WQ station \\
\hline AMNET station & AN0490 & AN0493 & AN0498 \\
Impairment status & Moderately impaired & Moderately impaired & Moderately impaired \\
\hline
\end{tabular}




\section{Toms River}

For the one station on the Toms River, station 01408500 near Toms River, the 5-year and period-of-record medians are similar for all constituents (table 6a). The period-of-record median for DO at this site is the largest for DO in the study area. The regression slopes of concentration to streamflow for HARD, TOC, SS, NA, DO, FDO, TP, TN, NO32, TAON, and PB show seasonal dependency. The regression slopes of load to streamflow are in the low range for HARD, TP, TN, NO32, and NH4, indicating smaller contributions of these constituents from storm runoff relative to that at other sites in the study area. During low flows, the trend is positive for NA and CL, indicating an increase in the contributions from point sources and ground water over time, and negative for TP, indicating a decrease in the contributions from point sources and ground water over time. The trends are insignificant for HARD, SS, DS, DO, FDO, TN, NO32, and TAON during low flows. During high flows, the trend is positive for CL, indicating an increase in the contribution of CL from storm runoff over time, and negative for HARD and TP, indicating a decrease in the contributions of these constituents from storm runoff over time. The trends are insignificant for SS, DS, NA, DO, FDO, TN, NO32, and TAON during high flows. Insufficient data are available to determine trends for ALK, TOC, NO2, NH4, B, PB, and BACT during low and high flows. The AMNET impairment status is non-impaired upstream from and at station 01408000 (table 6b).

\section{Mullica River}

Six water-quality stations are located in the Mullica River Basin on the Mullica River, Hammonton Creek, Batsto River, West Branch of the Wading River, Oswego River, and Bass River. For the one station on the Mullica River, station 01409387 at the outlet of Atsion Lake, the 5-year and period-of-record medians are similar for all constituents (table 7a). The regression slopes of concentration to streamflow for HARD, TOC, NA, DO, NO32, NO2, and NH4 show seasonal dependency. The regression slopes of load to streamflow for NA, CL, and B are in the high range, indicating greater contributions of these constituents from storm runoff relative to that at other sites in the study area. Load slopes for ALK, SS, and TAON are in the low range, indicating smaller contributions of these constituents from storm runoff relative to that at other sites in the study area. The load slopes for ALK and SS at station 01408500 are the smallest for these constituents in the study area. During low flows, the trends are insignificant for TOC, NA, DO, FDO, TN, NO32, TAON, NH4, and BACT. Insufficient data are available to determine trends for all other constituents during low flows and for all constituents during high flows. The AMNET impairment status is non-impaired upstream from station 01409387 and moderately impaired downstream from the station (table 7b).

For the one station on the Hammonton Creek, station 01409416 at Westcoatville, the 5-year medians are smaller than the period-of-record medians for TP, TAON, and NH4 and larger for NO32; 5-year and period-of-record medians are similar for all other constituents (table 8a). The regression slopes of concentration to streamflow for HARD, TOC, SS, DS, NA, DO, FDO, TN, NO32, NH4, and BACT show seasonal dependency. The regression slope of load to streamflow for ALK is in the high range, indicating a greater contribution of ALK from storm runoff relative to that at other sites in the study area. Load slopes for TOC, SS, DS, NA, TP, TN, and TAON are in the low range, indicating smaller contributions of these constituents from storm 
Table 6a. Median concentrations, relations of concentration and load to streamflow, and directions of concentration trends for selected waterquality constituents at water-quality station 01408500, Toms River near Toms River, N.J.

[Number in parenthesis is the number of available data values; WY, water years; $\mathrm{mg} / \mathrm{L}$, milligrams per liter; $\mathrm{CaCO}_{3}$, calcium carbonate; $\mathrm{C}$, carbon; Na, sodium; $\mathrm{Cl}$, chloride; \%, percent; $\mathrm{P}$, phosphorus; $\mathrm{N}$, nitrogen; $\mu \mathrm{g} / \mathrm{L}$, micrograms per liter; $\mathrm{B}$, boron; $\mathrm{Pb}$, lead; MPN/100 mL, most probable number per 100 milliliters. Regression slopes and trend directions are zero when the slope is not different from zero at the 0.05 significance level; * indicates seasonal dependency (the slope and (or) intercept of growing (April through October) and non-growing (November through March) season data were different at the 0.05 significance level); +, positive trend direction; -,negative trend direction; NA, insufficient data for analysis; ND, undetermined value]

\begin{tabular}{|c|c|c|c|c|c|c|c|c|c|}
\hline \multirow{3}{*}{$\begin{array}{c}\text { Constituent } \\
\text { Alkalinity, } \mathrm{mg} / \mathrm{L} \text { as } \mathrm{CaCO}_{3}\end{array}$} & \multirow{2}{*}{\multicolumn{2}{|c|}{$\begin{array}{c}\text { 1989-93 WY } \\
\text { Median } \\
\text { concentration }\end{array}$}} & \multicolumn{7}{|c|}{ 1976-93 WY } \\
\hline & & & \multicolumn{2}{|c|}{$\begin{array}{l}\text { Median } \\
\text { concentration }\end{array}$} & \multicolumn{2}{|c|}{$\begin{array}{c}\text { Regression } \\
\text { slope of } \\
\text { concentration to } \\
\text { streamflow }\end{array}$} & \multirow{2}{*}{$\begin{array}{c}\begin{array}{c}\text { Regression } \\
\text { slope of } \\
\text { load to } \\
\text { streamflow }\end{array} \\
0.290\end{array}$} & \multirow{2}{*}{$\begin{array}{c}\begin{array}{c}\text { Low- } \\
\text { flow } \\
\text { trend } \\
\text { direction }\end{array} \\
\text { NA }\end{array}$} & \multirow{2}{*}{$\begin{array}{c}\begin{array}{c}\text { High- } \\
\text { flow } \\
\text { trend } \\
\text { direction }\end{array} \\
\text { NA }\end{array}$} \\
\hline & 1 & $(30)$ & 2 & (77) & -0.708 & & & & \\
\hline Hardness, $\mathrm{mg} / \mathrm{L}$ as $\mathrm{CaCO}_{3}$ & 11 & (29) & 11 & $(134)$ & -.184 & $*$ & .816 & 0 & - \\
\hline Total organic carbon, $\mathrm{mg} / \mathrm{L}$ as $\mathrm{C}$ & ND & $(0)$ & 6.8 & $(65)$ & .398 & $*$ & 1.398 & NA & NA \\
\hline Suspended sediment, $\mathrm{mg} / \mathrm{L}$ & 8 & $(30)$ & 9 & $(134)$ & .405 & * & 1.405 & 0 & 0 \\
\hline Dissolved solids, mg/L & 42 & (29) & 44 & $(132)$ & -.056 & & .944 & 0 & 0 \\
\hline Dissolved sodium, $\mathrm{mg} / \mathrm{L}$ as $\mathrm{Na}$ & 6 & $(29)$ & 5 & $(137)$ & -.234 & $*$ & .766 & + & 0 \\
\hline Dissolved chloride, $\mathrm{mg} / \mathrm{L}$ as $\mathrm{Cl}$ & 10 & $(30)$ & 8 & $(135)$ & -.222 & & .778 & + & + \\
\hline Dissolved oxygen, $\mathrm{mg} / \mathrm{L}$ & 9.6 & $(30)$ & 9.5 & (136) & 0 & $*$ & 1.013 & 0 & 0 \\
\hline $\begin{array}{l}\text { Fraction of dissolved oxygen at } \\
\text { saturation, } \%\end{array}$ & 91 & (29) & 91 & $(133)$ & -.066 & $*$ & ND & 0 & 0 \\
\hline Total phosphorus, $\mathrm{mg} / \mathrm{L}$ as $\mathrm{P}$ & .02 & $(30)$ & .03 & $(135)$ & -.324 & $*$ & .675 & - & - \\
\hline Total nitrogen, $\mathrm{mg} / \mathrm{L}$ as $\mathrm{N}$ & .9 & $(29)$ & .8 & $(127)$ & -.314 & $*$ & .685 & 0 & 0 \\
\hline Total nitrate plus nitrite, $\mathrm{mg} / \mathrm{L}$ as $\mathrm{N}$ & .40 & (29) & .39 & (133) & -.683 & * & .317 & 0 & 0 \\
\hline Total nitrite, $\mathrm{mg} / \mathrm{L}$ as $\mathrm{N}$ & .008 & (18) & .010 & $(27)$ & 0 & & .909 & NA & NA \\
\hline $\begin{array}{l}\text { Total ammonia plus organic nitrogen, } \\
\mathrm{mg} / \mathrm{L} \text { as } \mathrm{N}\end{array}$ & .40 & $(30)$ & .40 & $(130)$ & 0 & $*$ & 1.026 & 0 & 0 \\
\hline Total ammonia, $\mathrm{mg} / \mathrm{L}$ as $\mathrm{N}$ & .16 & $(25)$ & .10 & $(112)$ & -.432 & & .568 & NA & NA \\
\hline Total boron, $\mu \mathrm{g} / \mathrm{L}$ as $\mathrm{B}$ & ND & $(0)$ & 30 & (1) & ND & & ND & NA & NA \\
\hline Total lead, $\mu \mathrm{g} / \mathrm{L}$ as $\mathrm{Pb}$ & ND & $(0)$ & 7 & $(27)$ & 0 & $*$ & .944 & NA & NA \\
\hline Fecal coliform bacteria, MPN/100 ml & ND & $(0)$ & 20 & (4) & ND & & ND & NA & NA \\
\hline
\end{tabular}

Table 6b. 1993 AMNET impairment status in the vicinity of water-quality station 01408500, Toms River near Toms River, N.J.

[AMNET, Ambient Biomonitoring Network; WQ, water-quality. Upstream from WQ station is within 5 miles upstream from the WQ station; at WQ-station location is within 0.5 mile upstream or downstream from the WQ station; downstream from WQ station is within 5 miles downstream from the WQ station; ND, undetermined impairment status]

\begin{tabular}{lccc}
\hline & Upstream from WQ station & At WQ-station location & Downstream from WQ station \\
\hline AMNET station & AN0524 & AN0535 & None \\
Impairment status & Non-impaired & Non-impaired & ND \\
\hline
\end{tabular}


Table 7a. Median concentrations, relations of concentration and load to streamflow, and directions of concentration trends for selected waterquality constituents at water-quality station 01409387, Mullica River at outlet of Atsion Lake, at Atsion, N.J.

[Number in parenthesis is the number of available data values; WY, water years; $\mathrm{mg} / \mathrm{L}$, milligrams per liter; $\mathrm{CaCO}_{3}$, calcium carbonate; $\mathrm{C}$, carbon; Na, sodium; $\mathrm{Cl}$, chloride; \%, percent; $\mathrm{P}$, phosphorus; $\mathrm{N}$, nitrogen; $\mu \mathrm{g} / \mathrm{L}$, micrograms per liter; $\mathrm{B}$, boron; Pb, lead; MPN/100 mL, most probable number per 100 milliliters. Regression slopes and trend directions are zero when the slope is not different from zero at the 0.05 significance level; * indicates seasonal dependency (the slope and (or) intercept of growing (April through October) and non-growing (November through March) season data were different at the 0.05 significance level); +, positive trend direction; -, negative trend direction; NA, insufficient data for analysis; ND, undetermined value]

\begin{tabular}{|c|c|c|c|c|c|c|}
\hline \multirow[b]{2}{*}{ Constituent } & \multirow{2}{*}{$\begin{array}{c}\text { 1989-93 WY } \\
\text { Median } \\
\text { concentration }\end{array}$} & \multicolumn{5}{|c|}{ 1976-93 WY } \\
\hline & & $\begin{array}{c}\text { Median } \\
\text { concentration }\end{array}$ & $\begin{array}{l}\text { Regression } \\
\text { slope of } \\
\text { concentration to } \\
\text { streamflow }\end{array}$ & $\begin{array}{l}\text { Regression } \\
\text { slope of } \\
\text { load to } \\
\text { streamflow }\end{array}$ & $\begin{array}{l}\text { Low- } \\
\text { flow } \\
\text { trend } \\
\text { direction }\end{array}$ & $\begin{array}{l}\text { High- } \\
\text { flow } \\
\text { trend } \\
\text { direction }\end{array}$ \\
\hline
\end{tabular}

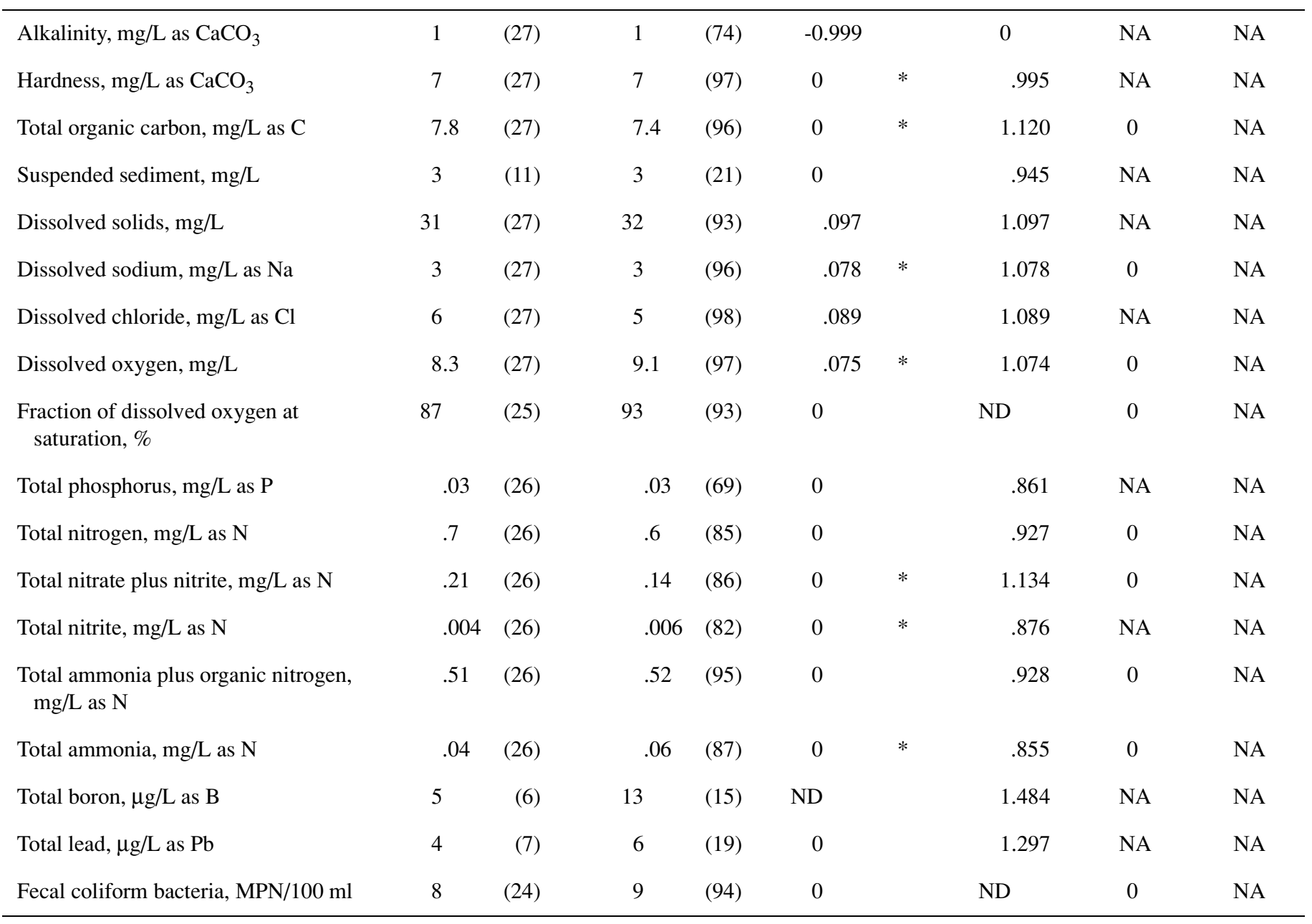

Table 7b. 1993 AMNET impairment status in the vicinity of water-quality station 01409387, Mullica River at outlet of Atsion Lake, at Atsion, N.J.

[AMNET, Ambient Biomonitoring Network; WQ, water-quality. Upstream from WQ station is within 5 miles upstream from the WQ station; at WQ-station location is within 0.5 mile upstream or downstream from the WQ station; downstream from WQ station is within 5 miles downstream from the WQ station; ND, undetermined impairment status]

\begin{tabular}{lccc} 
& Upstream from WQ station & At WQ-station location & Downstream from WQ station \\
\hline AMNET station & AN0562 & None & AN0564 \\
Impairment status & Non-impaired & ND & Moderately impaired \\
\hline
\end{tabular}


Table 8a. Median concentrations, relations of concentration and load to streamflow, and directions of concentration trends for selected waterquality constituents at water-quality station 01409416, Hammonton Creek at Westcoatville, N.J.

[Number in parenthesis is the number of available data values; WY, water years; $\mathrm{mg} / \mathrm{L}$, milligrams per liter; $\mathrm{CaCO}_{3}$, calcium carbonate; $\mathrm{C}$, carbon; Na, sodium; $\mathrm{Cl}$, chloride; \%, percent; $\mathrm{P}$, phosphorus; $\mathrm{N}$, nitrogen; $\mu \mathrm{g} / \mathrm{L}$, micrograms per liter; $\mathrm{B}$, boron; $\mathrm{Pb}$, lead; MPN/100 mL, most probable number per 100 milliliters. Regression slopes and trend directions are zero when the slope is not different from zero at the 0.05 significance level; * indicates seasonal dependency (the slope and (or) intercept of growing (April through October) and non-growing (November through March) season data were different at the 0.05 significance level); +, positive trend direction; -, negative trend direction; NA, insufficient data for analysis; ND, undetermined value]

\begin{tabular}{|c|c|c|c|c|c|c|c|c|c|}
\hline \multirow{3}{*}{$\begin{array}{c}\text { Constituent } \\
\text { Alkalinity, } \mathrm{mg} / \mathrm{L} \text { as } \mathrm{CaCO}_{3}\end{array}$} & \multirow{2}{*}{\multicolumn{2}{|c|}{$\begin{array}{c}\text { 1989-93 WY } \\
\text { Median } \\
\text { concentration }\end{array}$}} & \multicolumn{7}{|c|}{ 1976-93 WY } \\
\hline & & & \multicolumn{2}{|c|}{$\begin{array}{l}\text { Median } \\
\text { concentration }\end{array}$} & \multicolumn{2}{|c|}{$\begin{array}{c}\text { Regression } \\
\text { slope of } \\
\text { concentration to } \\
\text { streamflow }\end{array}$} & \multirow{2}{*}{$\begin{array}{c}\begin{array}{c}\text { Regression } \\
\text { slope of } \\
\text { load to } \\
\text { streamflow }\end{array} \\
0.869\end{array}$} & \multirow{2}{*}{$\begin{array}{c}\begin{array}{c}\text { Low- } \\
\text { flow } \\
\text { trend } \\
\text { direction }\end{array} \\
\text { NA }\end{array}$} & \multirow{2}{*}{$\begin{array}{c}\text { High- } \\
\text { flow } \\
\text { trend } \\
\text { direction } \\
\text { NA }\end{array}$} \\
\hline & 6 & $(27)$ & 6 & $(75)$ & 0 & & & & \\
\hline Hardness, $\mathrm{mg} / \mathrm{L}$ as $\mathrm{CaCO}_{3}$ & 23 & $(27)$ & 21 & $(91)$ & 0 & $*$ & 1.011 & 0 & NA \\
\hline Total organic carbon, $\mathrm{mg} / \mathrm{L}$ as $\mathrm{C}$ & 6.9 & (26) & 7.4 & $(93)$ & 0 & $*$ & .955 & 0 & NA \\
\hline Suspended sediment, $\mathrm{mg} / \mathrm{L}$ & 6 & $(10)$ & 7 & $(21)$ & 0 & * & 1.008 & NA & NA \\
\hline Dissolved solids, mg/L & 76 & (26) & 82 & (93) & -.175 & $*$ & .825 & 0 & NA \\
\hline Dissolved sodium, $\mathrm{mg} / \mathrm{L}$ as $\mathrm{Na}$ & 11 & $(27)$ & 12 & $(95)$ & -.391 & * & 609 & 0 & NA \\
\hline Dissolved chloride, $\mathrm{mg} / \mathrm{L}$ as $\mathrm{Cl}$ & 14 & (26) & 14 & $(94)$ & -.223 & & .777 & 0 & NA \\
\hline Dissolved oxygen, $\mathrm{mg} / \mathrm{L}$ & 5.9 & $(27)$ & 4.8 & $(98)$ & .124 & * & 1.124 & 0 & NA \\
\hline $\begin{array}{l}\text { Fraction of dissolved oxygen at } \\
\text { saturation, } \%\end{array}$ & 57 & $(25)$ & 50 & (89) & 0 & $*$ & ND & 0 & NA \\
\hline Total phosphorus, $\mathrm{mg} / \mathrm{L}$ as $\mathrm{P}$ & .45 & $(27)$ & .59 & $(65)$ & -.495 & & .505 & NA & NA \\
\hline Total nitrogen, $\mathrm{mg} / \mathrm{L}$ as $\mathrm{N}$ & 4.0 & $(27)$ & 4.8 & $(87)$ & -.213 & * & .786 & 0 & NA \\
\hline Total nitrate plus nitrite, $\mathrm{mg} / \mathrm{L}$ as $\mathrm{N}$ & 2.60 & $(27)$ & 1.80 & $(90)$ & -.154 & * & .846 & 0 & NA \\
\hline Total nitrite, $\mathrm{mg} / \mathrm{L}$ as $\mathrm{N}$ & .042 & $(26)$ & .042 & $(70)$ & -.383 & & .617 & NA & NA \\
\hline $\begin{array}{l}\text { Total ammonia plus organic nitrogen, } \\
\mathrm{mg} / \mathrm{L} \text { as } \mathrm{N}\end{array}$ & 1.59 & $(27)$ & 2.30 & $(92)$ & -.168 & & .832 & 0 & NA \\
\hline Total ammonia, $\mathrm{mg} / \mathrm{L}$ as $\mathrm{N}$ & .68 & $(27)$ & 1.12 & $(89)$ & 0 & $*$ & .759 & 0 & NA \\
\hline Total boron, $\mu \mathrm{g} / \mathrm{L}$ as $\mathrm{B}$ & 50 & (5) & 60 & (14) & 0 & & .884 & NA & NA \\
\hline Total lead, $\mu \mathrm{g} / \mathrm{L}$ as $\mathrm{Pb}$ & 4 & $(6)$ & 7 & $(18)$ & 0 & & 1.110 & NA & NA \\
\hline Fecal coliform bacteria, MPN/100 ml & 60 & $(25)$ & 50 & $(95)$ & 0 & $*$ & ND & + & NA \\
\hline
\end{tabular}

Table 8b. 1993 AMNET impairment status in the vicinity of water-quality station 01409416, Hammonton Creek at Westcoatville, N.J.

[AMNET, Ambient Biomonitoring Network; WQ, water-quality. Upstream from WQ station is within 5 miles upstream from the WQ station; at WQ-station location is within 0.5 mile upstream or downstream from the WQ station; downstream from WQ station is within 5 miles downstream from the WQ station; ND, undetermined impairment status]

\begin{tabular}{lccc}
\hline & Upstream from WQ station & At WQ-station location & Downstream from WQ station \\
\hline AMNET station & AN0577 & None & AN0578 \\
Impairment status & Severely impaired & ND & Non-impaired \\
\hline
\end{tabular}


runoff relative to that at other sites in the study area. The load slopes for NA and TP at station 01409416 are the smallest for these constituents in the study area. During low flows, the trend is positive for BACT, indicating an increase in the contributions of BACT from point sources and ground water over time, and insignificant for TOC, NA, DO, FDO, TN, NO32, TAON, NH4, and BACT. Insufficient data are available to determine trends for all other constituents during low flows and for all constituents during high flows. The AMNET impairment status is severely impaired upstream and non-impaired downstream from station 01409416 (table 8b).

For the one station on the Batsto River, station 01409500 at Batsto, the 5-year and periodof-record medians are similar for all constituents (table 9a). The period-of-record medians for NA, CL, and B at station 01409500 are the smallest for these constituents of all stations in the study area. The regression slopes of concentration to streamflow for ALK, HARD, TOC, CL, DO, and NO32 show seasonal dependency. The regression slopes of load to streamflow for HARD, DS, NA, CL, TN, and NH4 are in the high range, indicating greater contributions of these constituents from storm runoff relative to that at other sites in the study area. The load slopes for HARD and CL at station 01409416 are the largest for these constituents in the study area. Load slope for ALK is in the low range, indicating smaller contributions of this constituent from storm runoff relative to that at other sites in the study area. The load slope for HARD at station 01409416 is the largest for HARD in the study area. Trends are insignificant for HARD, TOC, DS, NA, CL, DO, FDO, TN, NO32, NO2, TAON, NH4, and BACT during low flow. Insufficient data are available to determine trends for all constituents during high flows. The AMNET impairment status is non-impaired at station 01409500 and moderately impaired upstream from the station (table 9b).

For the one station on the West Branch of the Wading River, station 01409815 at Maxwell, the 5-year and period-of-record medians are similar for all constituents (table 10a). The periodof-record medians for ALK, HARD, NA, CL, TN, NO32, and NH4 at station 01409815 are the smallest for these constituents at all stations in the study area. The regression slopes of concentration to streamflow for HARD, SS, DS, NA, DO, FDO, TP, TN, and TAON show seasonal dependency. The regression slope of load to streamflow for ALK is in the high range, indicating a greater contribution from storm runoff relative to that at other sites in the study area. Load slopes for TOC, SS, and NH4 are in the low range, indicating a smaller contribution from storm runoff relative to that at other sites in the study area. During low flows, the trends are positive for NA and CL, indicating an increase in the contributions of these constituents from point sources and ground water over time. The trends are insignificant for HARD, DS, DO, FDO, TP, and TAON during low flow. Insufficient data are available to determine trends for all other constituents during low flows and for all constituents during high flows. The AMNET impairment status is non-impaired at station 01409815 (table 10b).

For the one station on the Oswego River, station 01410000 at Harrisville, the 5-year median is greater than the period-of-record median for NO32; 5-year and period-of-record medians are similar for all other constituents (table 11a). The period-of-record medians for ALK, NA, CL, PB, and BACT at station 01410000 are the smallest for these constituents at all stations in the study area. The regression slopes of concentration to streamflow for TOC, DO, TN, and TAON show seasonal dependency. The regression slope of load to streamflow for NO2 is in the high range, indicating a greater contribution from storm runoff relative to that at other sites in the 
Table 9a. Median concentrations, relations of concentration and load to streamflow, and directions of concentration trends for selected waterquality constituents at water-quality station 01409500, Batsto River at Batsto, N.J.

[Number in parenthesis is the number of available data values; WY, water years; $\mathrm{mg} / \mathrm{L}$, milligrams per liter; $\mathrm{CaCO}_{3}$, calcium carbonate; $\mathrm{C}$, carbon; Na, sodium; $\mathrm{Cl}$, chloride; \%, percent; $\mathrm{P}$, phosphorus; $\mathrm{N}$, nitrogen; $\mu \mathrm{g} / \mathrm{L}$, micrograms per liter; $\mathrm{B}$, boron; $\mathrm{Pb}$, lead; MPN/100 mL, most probable number per 100 milliliters. Regression slopes and trend directions are zero when the slope is not different from zero at the 0.05 significance level; * indicates seasonal dependency (the slope and (or) intercept of growing (April through October) and non-growing (November through March) season data were different at the 0.05 significance level); +, positive trend direction; -, negative trend direction; NA, insufficient data for analysis; ND, undetermined value]

\begin{tabular}{|c|c|c|c|c|c|c|c|c|c|}
\hline \multirow{3}{*}{$\begin{array}{l}\text { Constituent } \\
\text { ag/L as } \mathrm{CaCO}_{3}\end{array}$} & \multirow{2}{*}{\multicolumn{2}{|c|}{$\begin{array}{c}\text { 1989-93 WY } \\
\text { Median } \\
\text { concentration }\end{array}$}} & \multicolumn{7}{|c|}{ 1976-93 WY } \\
\hline & & & \multicolumn{2}{|c|}{$\begin{array}{l}\text { Median } \\
\text { concentration }\end{array}$} & \multicolumn{2}{|c|}{$\begin{array}{c}\text { Regression } \\
\text { slope of } \\
\text { concentration to } \\
\text { streamflow }\end{array}$} & \multirow{2}{*}{$\begin{array}{c}\begin{array}{c}\text { Regression } \\
\text { slope of } \\
\text { load to } \\
\text { streamflow }\end{array} \\
0\end{array}$} & \multirow{2}{*}{$\begin{array}{c}\begin{array}{c}\text { Low- } \\
\text { flow } \\
\text { trend } \\
\text { direction }\end{array} \\
\text { NA }\end{array}$} & \multirow{2}{*}{$\begin{array}{c}\text { High- } \\
\text { flow } \\
\text { trend } \\
\text { direction } \\
\text { NA }\end{array}$} \\
\hline & 2 & $(27)$ & 2 & (73) & -0.778 & $*$ & & & \\
\hline Hardness, $\mathrm{mg} / \mathrm{L}$ as $\mathrm{CaCO}_{3}$ & 9 & $(27)$ & 8 & (99) & .305 & $*$ & 1.305 & 0 & NA \\
\hline Total organic carbon, $\mathrm{mg} / \mathrm{L}$ as $\mathrm{C}$ & 5.8 & (26) & 5.5 & $(97)$ & .475 & $*$ & 1.475 & 0 & NA \\
\hline Suspended sediment, $\mathrm{mg} / \mathrm{L}$ & 2 & (11) & 3 & $(30)$ & 0 & & 1.402 & NA & NA \\
\hline Dissolved solids, mg/L & 31 & (26) & 32 & (93) & .287 & & 1.287 & 0 & NA \\
\hline Dissolved sodium, $\mathrm{mg} / \mathrm{L}$ as $\mathrm{Na}$ & 3 & $(27)$ & 2 & (99) & 0 & & 1.014 & 0 & NA \\
\hline Dissolved chloride, $\mathrm{mg} / \mathrm{L}$ as $\mathrm{Cl}$ & 5 & $(27)$ & 4 & $(100)$ & .128 & $*$ & 1.128 & 0 & NA \\
\hline Dissolved oxygen, $\mathrm{mg} / \mathrm{L}$ & 9.0 & $(27)$ & 9.2 & (99) & 0 & $*$ & 1.037 & 0 & NA \\
\hline $\begin{array}{l}\text { Fraction of dissolved oxygen at } \\
\text { saturation, } \%\end{array}$ & 87 & (24) & 89 & (95) & -.064 & & ND & 0 & NA \\
\hline Total phosphorus, $\mathrm{mg} / \mathrm{L}$ as $\mathrm{P}$ & .03 & $(26)$ & .02 & $(68)$ & 0 & & .817 & NA & NA \\
\hline Total nitrogen, $\mathrm{mg} / \mathrm{L}$ as $\mathrm{N}$ & .6 & (26) & .5 & $(83)$ & .336 & & 1.336 & 0 & NA \\
\hline Total nitrate plus nitrite, $\mathrm{mg} / \mathrm{L}$ as $\mathrm{N}$ & .24 & (26) & .10 & $(85)$ & .642 & * & 1.642 & 0 & NA \\
\hline Total nitrite, $\mathrm{mg} / \mathrm{L}$ as $\mathrm{N}$ & .004 & (26) & .004 & (79) & 0 & & 1.136 & 0 & NA \\
\hline $\begin{array}{l}\text { Total ammonia plus organic nitrogen, } \\
\mathrm{mg} / \mathrm{L} \text { as } \mathrm{N}\end{array}$ & .40 & $(27)$ & .36 & $(95)$ & .250 & & 1.250 & 0 & NA \\
\hline Total ammonia, $\mathrm{mg} / \mathrm{L}$ as $\mathrm{N}$ & .03 & $(27)$ & .05 & $(88)$ & 0 & & 1.465 & 0 & NA \\
\hline Total boron, $\mu \mathrm{g} / \mathrm{L}$ as $\mathrm{B}$ & $<10$ & (5) & 5 & (13) & ND & & ND & NA & NA \\
\hline Total lead, $\mu \mathrm{g} / \mathrm{L}$ as $\mathrm{Pb}$ & 2 & (6) & 3 & $(15)$ & 0 & & 1.072 & NA & NA \\
\hline Fecal coliform bacteria, MPN/100 ml & 6 & $(25)$ & 8 & (99) & 1.006 & & ND & 0 & NA \\
\hline
\end{tabular}

Table 9b. 1993 AMNET impairment status in the vicinity of water-quality station 01409500, Batsto River at Batsto, N.J.

[AMNET, Ambient Biomonitoring Network; WQ, water-quality. Upstream from WQ station is within 5 miles upstream from the WQ station; at WQ-station location is within 0.5 mile upstream or downstream from the WQ station; downstream from WQ station is within 5 miles downstream from the WQ station; ND, undetermined impairment status]

\begin{tabular}{lccc}
\hline & Upstream from WQ station & At WQ-station location & Downstream from WQ station \\
\hline AMNET station & AN0586 & AN0588 & None \\
Impairment status & Moderately impaired & Non-impaired & ND \\
\hline
\end{tabular}


Table 10a. Median concentrations, relations of concentration and load to streamflow, and directions of concentration trends for selected waterquality constituents at water-quality station 01409815, West Branch Wading River at Maxwell, N.J.

[Number in parenthesis is the number of available data values; WY, water years; $\mathrm{mg} / \mathrm{L}$, milligrams per liter; $\mathrm{CaCO}_{3}$, calcium carbonate; $\mathrm{C}$, carbon; Na, sodium; $\mathrm{Cl}$, chloride; \%, percent; $\mathrm{P}$, phosphorus; $\mathrm{N}$, nitrogen; $\mu \mathrm{g} / \mathrm{L}$, micrograms per liter; $\mathrm{B}$, boron; Pb, lead; MPN/100 mL, most probable number per 100 milliliters. Regression slopes and trend directions are zero when the slope is not different from zero at the 0.05 significance level; * indicates seasonal dependency (the slope and (or) intercept of growing (April through October) and non-growing (November through March) season data were different at the 0.05 significance level); +, positive trend diretcion; -, negative trend direction; NA, insufficient data for analysis; ND, undetermined value]

\begin{tabular}{|c|c|c|c|c|c|c|}
\hline \multirow[b]{2}{*}{ Constituent } & \multirow{2}{*}{$\begin{array}{c}\text { 1989-93 WY } \\
\text { Median } \\
\text { concentration }\end{array}$} & \multicolumn{5}{|c|}{ 1976-93 WY } \\
\hline & & $\begin{array}{c}\text { Median } \\
\text { concentration }\end{array}$ & $\begin{array}{l}\text { Regression } \\
\text { slope of } \\
\text { concentration to } \\
\text { streamflow }\end{array}$ & $\begin{array}{l}\text { Regression } \\
\text { slope of } \\
\text { load to } \\
\text { streamflow }\end{array}$ & $\begin{array}{l}\text { Low- } \\
\text { flow } \\
\text { trend } \\
\text { direction }\end{array}$ & $\begin{array}{l}\text { High- } \\
\text { flow } \\
\text { trend } \\
\text { direction }\end{array}$ \\
\hline
\end{tabular}

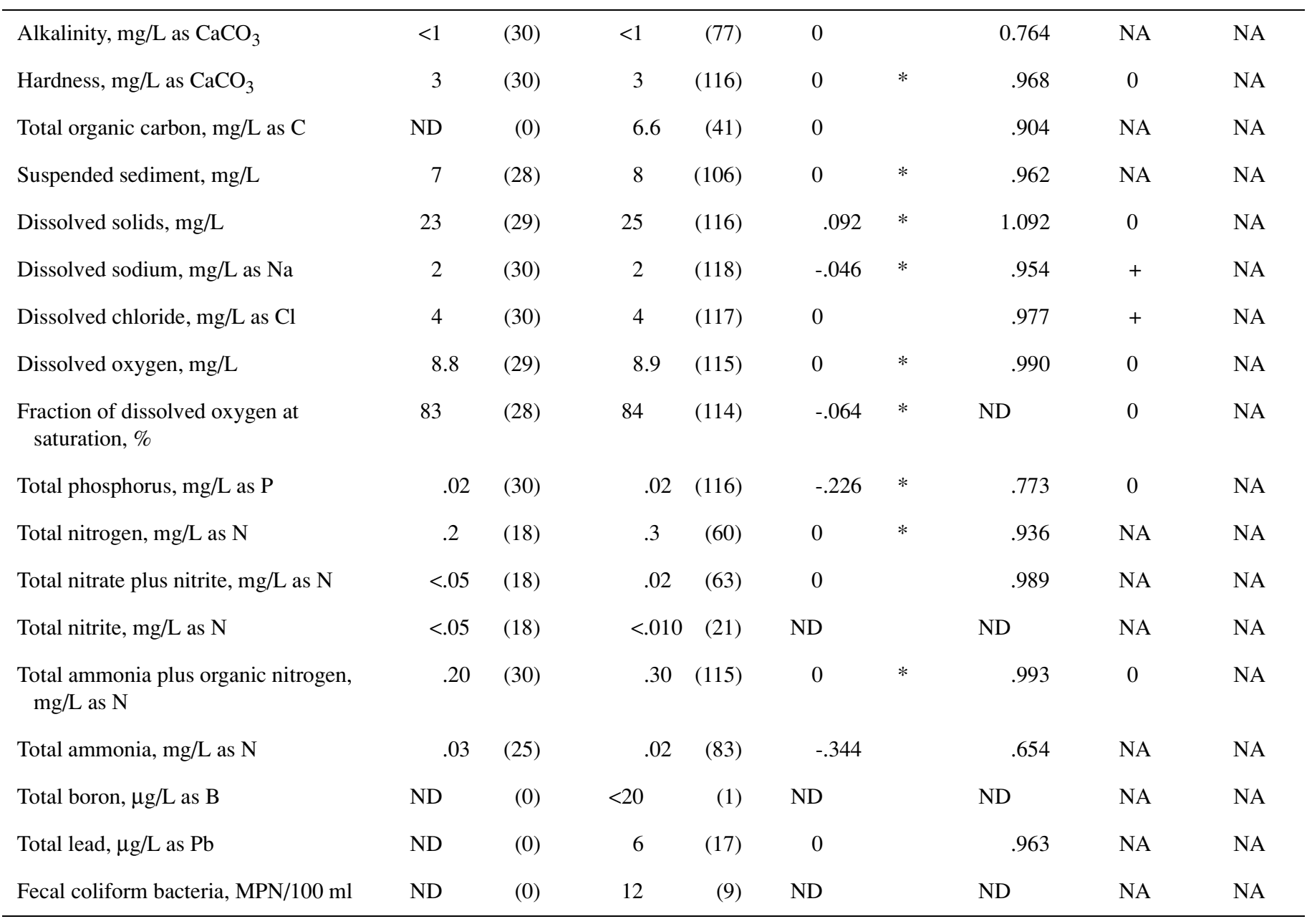

Table 10b. 1993 AMNET impairment status in the vicinity of water-quality station 01409815, West Branch Wading River at Maxwell, N.J.

[AMNET, Ambient Biomonitoring Network; WQ, water-quality. Upstream from WQ station is within 5 miles upstream from the WQ station; at WQ-station location is within 0.5 mile upstream or downstream from the WQ station; downstream from WQ station is within 5 miles downstream from the WQ station; ND, undetermined impairment status]

\begin{tabular}{lccc}
\hline & Upstream from WQ station & At WQ-station location & Downstream from WQ station \\
\hline AMNET station & None & AN0602 & None \\
Impairment status & ND & Non-impaired & ND \\
\hline
\end{tabular}


Table 11a. Median concentrations, relations of concentration and load to streamflow, and directions of concentration trends for selected waterquality constituents at water-quality station 01410000, Oswego River at Harrisville, N.J.

[Number in parenthesis is the number of available data values; WY, water years; $\mathrm{mg} / \mathrm{L}$, milligrams per liter; $\mathrm{CaCO}_{3}$, calcium carbonate; $\mathrm{C}$, carbon; Na, sodium; $\mathrm{Cl}$, chloride; \%, percent; $\mathrm{P}$, phosphorus; $\mathrm{N}$, nitrogen; $\mu \mathrm{g} / \mathrm{L}$, micrograms per liter; $\mathrm{B}$, boron; $\mathrm{Pb}$, lead; MPN/100 mL, most probable number per 100 milliliters. Regression slopes and trend directions are zero when the slope is not different from zero at the 0.05 significance level; * indicates seasonal dependency (the slope and (or) intercept of growing (April through October) and non-growing (November through March) season data were different at the 0.05 significance level); +, positive trend direction; -, negative trend direction; NA, insufficient data for analysis; ND, undetermined value]

\begin{tabular}{|c|c|c|c|c|c|c|c|c|c|}
\hline \multirow{3}{*}{$\begin{array}{c}\text { Constituent } \\
\text { Alkalinity, } \mathrm{mg} / \mathrm{L} \text { as } \mathrm{CaCO}_{3}\end{array}$} & \multirow{2}{*}{\multicolumn{2}{|c|}{$\begin{array}{c}\text { 1989-93 WY } \\
\begin{array}{c}\text { Median } \\
\text { concentration }\end{array}\end{array}$}} & \multicolumn{7}{|c|}{ 1976-93 WY } \\
\hline & & & \multicolumn{2}{|c|}{$\begin{array}{c}\text { Median } \\
\text { concentration }\end{array}$} & \multicolumn{2}{|c|}{$\begin{array}{c}\text { Regression } \\
\text { slope of } \\
\text { concentration to } \\
\text { streamflow }\end{array}$} & \multirow{2}{*}{$\begin{array}{c}\begin{array}{c}\text { Regression } \\
\text { slope of } \\
\text { load to } \\
\text { streamflow }\end{array} \\
\text { ND }\end{array}$} & \multirow{2}{*}{$\begin{array}{c}\begin{array}{c}\text { Low- } \\
\text { flow } \\
\text { trend } \\
\text { direction }\end{array} \\
\text { NA }\end{array}$} & \multirow{2}{*}{$\begin{array}{c}\begin{array}{c}\text { High- } \\
\text { flow } \\
\text { trend } \\
\text { direction }\end{array} \\
\text { NA }\end{array}$} \\
\hline & $<1$ & (23) & $<1$ & (69) & ND & & & & \\
\hline Hardness, $\mathrm{mg} / \mathrm{L}$ as $\mathrm{CaCO}_{3}$ & 4 & $(23)$ & 4 & (93) & -0.073 & & 0.926 & 0 & NA \\
\hline Total organic carbon, $\mathrm{mg} / \mathrm{L}$ as $\mathrm{C}$ & 5.2 & $(22)$ & 4.6 & (94) & .489 & $*$ & 1.489 & 0 & NA \\
\hline Suspended sediment, $\mathrm{mg} / \mathrm{L}$ & 4 & (6) & 6 & (23) & 0 & & 1.314 & NA & NA \\
\hline Dissolved solids, mg/L & 24 & (23) & 26 & (93) & .112 & & 1.112 & 0 & NA \\
\hline Dissolved sodium, $\mathrm{mg} / \mathrm{L}$ as $\mathrm{Na}$ & 2 & $(23)$ & 2 & (96) & 0 & & .955 & 0 & NA \\
\hline Dissolved chloride, $\mathrm{mg} / \mathrm{L}$ as $\mathrm{Cl}$ & 4 & (23) & 4 & (93) & 0 & & .975 & NA & NA \\
\hline Dissolved oxygen, $\mathrm{mg} / \mathrm{L}$ & 8.8 & $(23)$ & 9.0 & $(95)$ & 0 & * & 1.046 & 0 & NA \\
\hline $\begin{array}{l}\text { Fraction of dissolved oxygen at } \\
\text { saturation, } \%\end{array}$ & 92 & $(22)$ & 93 & (93) & -.039 & & ND & 0 & NA \\
\hline Total phosphorus, $\mathrm{mg} / \mathrm{L}$ as $\mathrm{P}$ & .03 & $(23)$ & .02 & $(66)$ & 0 & & 1.088 & NA & NA \\
\hline Total nitrogen, $\mathrm{mg} / \mathrm{L}$ as $\mathrm{N}$ & .5 & $(23)$ & .4 & $(80)$ & .180 & $*$ & 1.180 & 0 & NA \\
\hline Total nitrate plus nitrite, $\mathrm{mg} / \mathrm{L}$ as $\mathrm{N}$ & .16 & $(23)$ & .04 & $(84)$ & 0 & & 1.256 & 0 & NA \\
\hline Total nitrite, $\mathrm{mg} / \mathrm{L}$ as $\mathrm{N}$ & .004 & $(22)$ & .004 & $(74)$ & .335 & & 1.335 & NA & NA \\
\hline $\begin{array}{l}\text { Total ammonia plus organic nitrogen, } \\
\mathrm{mg} / \mathrm{L} \text { as } \mathrm{N}\end{array}$ & .30 & $(23)$ & .34 & $(90)$ & .276 & * & 1.276 & - & NA \\
\hline Total ammonia, $\mathrm{mg} / \mathrm{L}$ as $\mathrm{N}$ & .04 & $(23)$ & .05 & $(88)$ & 0 & & 1.104 & 0 & NA \\
\hline Total boron, $\mu \mathrm{g} / \mathrm{L}$ as $\mathrm{B}$ & $<15$ & (4) & 20 & $(12)$ & ND & & ND & NA & NA \\
\hline Total lead, $\mu \mathrm{g} / \mathrm{L}$ as $\mathrm{Pb}$ & 1 & (5) & 2 & (14) & ND & & 1.274 & NA & NA \\
\hline Fecal coliform bacteria, MPN/100 ml & 10 & $(21)$ & 2 & $(94)$ & 1.207 & & ND & 0 & NA \\
\hline
\end{tabular}

Table 11b. 1993 AMNET impairment status in the vicinity of water-quality station 01410000, Oswego River at Harrisville, N.J.

[AMNET, Ambient Biomonitoring Network; WQ, water-quality. Upstream from WQ station is within 5 miles upstream from the WQ station; at WQ-station location is within 0.5 mile upstream or downstream from the WQ station; downstream from WQ station is within 5 miles downstream from the WQ station; ND, undetermined impairment status]

\begin{tabular}{lccc}
\hline & Upstream from WQ station & At WQ-station location & Downstream from WQ station \\
\hline AMNET station & AN0606 & AN0607 & None \\
Impairment status & Moderately impaired & Non-impaired & ND \\
\hline
\end{tabular}


study area. Load slope for DO is in the low range. During low flows, the trend is negative for TAON, indicating an increase in the contributions of TAON from point sources and ground water over time. The trends are insignificant for HARD, TOC, DS, NA, DO, FDO, TN, NO32, NH4, and BACT during low flows. Insufficient data are available to determine trends for all other constituents during low flows and for all constituents during high flows. The AMNET impairment status is non-impaired at station 01410000 and moderately impaired upstream from the station (table 11b).

For the one station on the East Branch of the Bass River, station 01410150 near New Gretna, the 5-year median is greater than the period-of-record median for NO32; 5-year and period-of-record medians are similar for all other constituents (table 12a). The period-of-record medians for SS and NO2 at station 01410150 are the smallest for these constituents at all stations in the study area. The regression slopes of concentration to streamflow for TOC, DO, and FDO show seasonal dependency. The regression slope of load to streamflow for TOC, NA, CL, and NO2 are in the high range, indicating a greater contribution from storm runoff relative to that at other sites in the study area. The load slope for CL at station 01410150 is the largest for this constituent in the study area. Load slope for ALK, NH4, and PB are in the low range, indicating smaller contributions of these constituents from storm runoff relative to that at other sites in the study area. During high flows, the trends are insignificant for HARD, TOC, DS, NA, CL, DO, FDO, TN, NO32, TAON, NH4, and BACT. Insufficient data are available to determine trends for all other constituents during low flows and for all constituents during high flows. The AMNET impairment status is non-impaired upstream from station 01410150 (table 12b).

\section{Great Egg Harbor River}

Three water-quality stations are located on the Great Egg Harbor River-stations 0140784 near Sicklerville, 01411000 at Folsom, and 01411110 at Weymouth. The 5-year medians are smaller than the period-of-record medians for TP, TN, NO32, NO2, TAON, and NH4 at station 01410784; 5-year and period-of-record medians are similar for all other constituents (table 13a). The 5-year and period-of-record medians are similar for all constituents at stations 01411000 and 01411110 (tables 14a and 15a). The regression slopes of concentration to streamflow for HARD, TOC, SS, DS, NA, CL, DO, FDO, and BACT show seasonal dependency at station 01410784. The concentration slopes for DO, FDO, TP, NO32, and BACT show seasonal dependency at station 01411000. The concentration slopes for ALK, TOC, NA, DO, FDO, TP, NO32, TAON, and BACT show seasonal dependency at station 01411110.

The load slope for TOC at station 01411000 is the largest for TOC in the study area. Load slopes are in the high range for TOC at station 01411000 and for TOC and NO2 at station 01411110, indicating greater contributions of these constituents from storm runoff relative to that at other sites in the study area. The regression slopes of load to streamflow are in the low range for HARD, TP, TN, and NO32 at station 01410784, for ALK, SS, DO, NO32, and NH4 at station 01411000, and for ALK, NO32, and B at station 01411110, indicating smaller contributions of these constituents from storm runoff relative to that at other sites in the study area. The load slopes for TN at station 01410784, ALK at station 01411000, and NO32 at station 01411110 are 
Table 12a. Median concentrations, relations of concentration and load to streamflow, and directions of concentration trends for selected waterquality constituents at water-quality station 01410150, East Branch Bass River near New Gretna, N.J.

[Number in parenthesis is the number of available data values; WY, water years; $\mathrm{mg} / \mathrm{L}$, milligrams per liter; $\mathrm{CaCO}_{3}$, calcium carbonate; $\mathrm{C}$, carbon; Na, sodium; $\mathrm{Cl}$, chloride; \%, percent; $\mathrm{P}$, phosphorus; $\mathrm{N}$, nitrogen; $\mu \mathrm{g} / \mathrm{L}$, micrograms per liter; $\mathrm{B}$, boron; $\mathrm{Pb}$, lead; MPN/100 mL, most probable number per 100 milliliters. Regression slopes and trend directions are zero when the slope is not different from zero at the 0.05 significance level; * indicates seasonal dependency (the slope and (or) intercept of growing (April through October) and non-growing (November through March) season data were different at the 0.05 significance level); +, positive trend direction; -, negative trend direction; NA, insufficient data for analysis; ND, undetermined value]

\begin{tabular}{|c|c|c|c|c|c|c|c|c|c|}
\hline \multirow[b]{2}{*}{ Constituent } & \multicolumn{2}{|c|}{ 1989-93 WY } & \multicolumn{7}{|c|}{ 1976-93 WY } \\
\hline & \multicolumn{2}{|c|}{$\begin{array}{l}\text { Median } \\
\text { concentration }\end{array}$} & \multicolumn{2}{|c|}{$\begin{array}{l}\text { Median } \\
\text { concentration }\end{array}$} & \multicolumn{2}{|c|}{$\begin{array}{l}\text { Regression } \\
\text { slope of } \\
\text { concentration to } \\
\text { streamflow }\end{array}$} & \multirow{2}{*}{$\begin{array}{c}\begin{array}{c}\text { Regression } \\
\text { slope of } \\
\text { load to } \\
\text { streamflow }\end{array} \\
0\end{array}$} & \multirow{2}{*}{$\begin{array}{c}\begin{array}{c}\text { Low- } \\
\text { flow } \\
\text { trend } \\
\text { direction }\end{array} \\
\text { NA }\end{array}$} & \multirow{2}{*}{$\begin{array}{c}\begin{array}{c}\text { High- } \\
\text { flow } \\
\text { trend } \\
\text { direction }\end{array} \\
\text { NA }\end{array}$} \\
\hline Alkalinity, $\mathrm{mg} / \mathrm{L}$ as $\mathrm{CaCO}_{3}$ & 1 & $(27)$ & 1 & $(75)$ & -0.553 & & & & \\
\hline Hardness, $\mathrm{mg} / \mathrm{L}$ as $\mathrm{CaCO}_{3}$ & 4 & $(26)$ & 4 & $(95)$ & 0 & & 1.069 & 0 & NA \\
\hline Total organic carbon, $\mathrm{mg} / \mathrm{L}$ as $\mathrm{C}$ & 5.0 & $(26)$ & 4.8 & $(96)$ & .602 & $*$ & 1.601 & 0 & NA \\
\hline Suspended sediment, $\mathrm{mg} / \mathrm{L}$ & 2 & $(10)$ & 2 & $(27)$ & 0 & & 1.452 & NA & NA \\
\hline Dissolved solids, $\mathrm{mg} / \mathrm{L}$ & 28 & $(27)$ & 29 & (93) & 0 & & 1.080 & 0 & NA \\
\hline Dissolved sodium, $\mathrm{mg} / \mathrm{L}$ as $\mathrm{Na}$ & 3 & (27) & 3 & $(98)$ & .079 & & 1.078 & 0 & NA \\
\hline Dissolved chloride, $\mathrm{mg} / \mathrm{L}$ as $\mathrm{Cl}$ & 6 & (27) & 5 & $(97)$ & .054 & & 1.054 & 0 & NA \\
\hline Dissolved oxygen, $\mathrm{mg} / \mathrm{L}$ & 7.6 & $(27)$ & 7.7 & $(97)$ & .105 & $*$ & 1.105 & 0 & NA \\
\hline $\begin{array}{l}\text { Fraction of dissolved oxygen at } \\
\text { saturation, } \%\end{array}$ & 72 & (26) & 75 & (93) & 0 & $*$ & ND & 0 & NA \\
\hline Total phosphorus, $\mathrm{mg} / \mathrm{L}$ as $\mathrm{P}$ & .02 & (26) & .02 & $(64)$ & 0 & & 1.077 & NA & NA \\
\hline Total nitrogen, $\mathrm{mg} / \mathrm{L}$ as $\mathrm{N}$ & .4 & $(27)$ & .4 & $(84)$ & 0 & & .997 & 0 & NA \\
\hline Total nitrate plus nitrite, $\mathrm{mg} / \mathrm{L}$ as $\mathrm{N}$ & .15 & $(27)$ & .05 & $(85)$ & 0 & & 1.295 & 0 & NA \\
\hline Total nitrite, $\mathrm{mg} / \mathrm{L}$ as $\mathrm{N}$ & .003 & $(26)$ & .003 & $(76)$ & 0 & & 1.267 & NA & NA \\
\hline $\begin{array}{l}\text { Total ammonia plus organic nitrogen, } \\
\mathrm{mg} / \mathrm{L} \text { as } \mathrm{N}\end{array}$ & .24 & (27) & .27 & $(91)$ & 0 & & 1.006 & 0 & NA \\
\hline Total ammonia, $\mathrm{mg} / \mathrm{L}$ as $\mathrm{N}$ & .03 & $(27)$ & .05 & $(86)$ & 0 & & .666 & 0 & NA \\
\hline Total boron, $\mu \mathrm{g} / \mathrm{L}$ as $\mathrm{B}$ & $<10$ & (7) & 10 & (13) & ND & & ND & NA & NA \\
\hline Total lead, $\mu \mathrm{g} / \mathrm{L}$ as $\mathrm{Pb}$ & 2 & (7) & 3 & $(16)$ & 0 & & 0 & NA & NA \\
\hline Fecal coliform bacteria, MPN/100 ml & 20 & $(25)$ & 10 & $(95)$ & 0 & & ND & 0 & NA \\
\hline
\end{tabular}

Table 12b. 1993 AMNET impairment status in the vicinity of water-quality station 01410150, East Branch Bass River near New Gretna, N.J.

[AMNET, Ambient Biomonitoring Network; WQ, water-quality. Upstream from WQ station is within 5 miles upstream from the WQ station; at WQ-station location is within 0.5 mile upstream or downstream from the WQ station; downstream from WQ station is within 5 miles downstream from the WQ station; ND, undetermined impairment status]

\begin{tabular}{lccc}
\hline & Upstream from WQ station & At WQ-station location & Downstream from WQ station \\
\hline AMNET station & AN0611 & None & None \\
Impairment status & Non-impaired & ND & ND \\
\hline
\end{tabular}


Table 13a. Median concentrations, relations of concentration and load to streamflow, and directions of concentration trends for selected waterquality constituents at water-quality station 01410784, Great Egg Harbor River near Sicklerville, N.J.

[Number in parenthesis is the number of available data values; WY, water years; $\mathrm{mg} / \mathrm{L}$, milligrams per liter; $\mathrm{CaCO}_{3}$, calcium carbonate; $\mathrm{C}$, carbon; Na, sodium; $\mathrm{Cl}$, chloride; \%, percent; $\mathrm{P}$, phosphorus; $\mathrm{N}$, nitrogen; $\mu \mathrm{g} / \mathrm{L}$, micrograms per liter; $\mathrm{B}$, boron; Pb, lead; MPN/100 mL, most probable number per 100 milliliters. Regression slopes and trend directions are zero when the slope is not different from zero at the 0.05 significance level; * indicates seasonal dependency (the slope and (or) intercept of growing (April through October) and non-growing (November through March) season data were different at the 0.05 significance level); +, positive trend direction; -, negative trend direction; NA, insufficient data for analysis; ND, undetermined value]

\begin{tabular}{|c|c|c|c|c|c|c|}
\hline \multirow[b]{2}{*}{ Constituent } & \multirow{2}{*}{$\begin{array}{c}\text { 1989-93 WY } \\
\text { Median } \\
\text { concentration }\end{array}$} & \multicolumn{5}{|c|}{ 1976-93 WY } \\
\hline & & $\begin{array}{c}\text { Median } \\
\text { concentration }\end{array}$ & $\begin{array}{c}\text { Regression } \\
\text { slope of } \\
\text { concentration to } \\
\text { streamflow }\end{array}$ & $\begin{array}{l}\text { Regression } \\
\text { slope of } \\
\text { load to } \\
\text { streamflow }\end{array}$ & $\begin{array}{l}\text { Low- } \\
\text { flow } \\
\text { trend } \\
\text { direction }\end{array}$ & $\begin{array}{l}\text { High- } \\
\text { flow } \\
\text { trend } \\
\text { direction }\end{array}$ \\
\hline
\end{tabular}

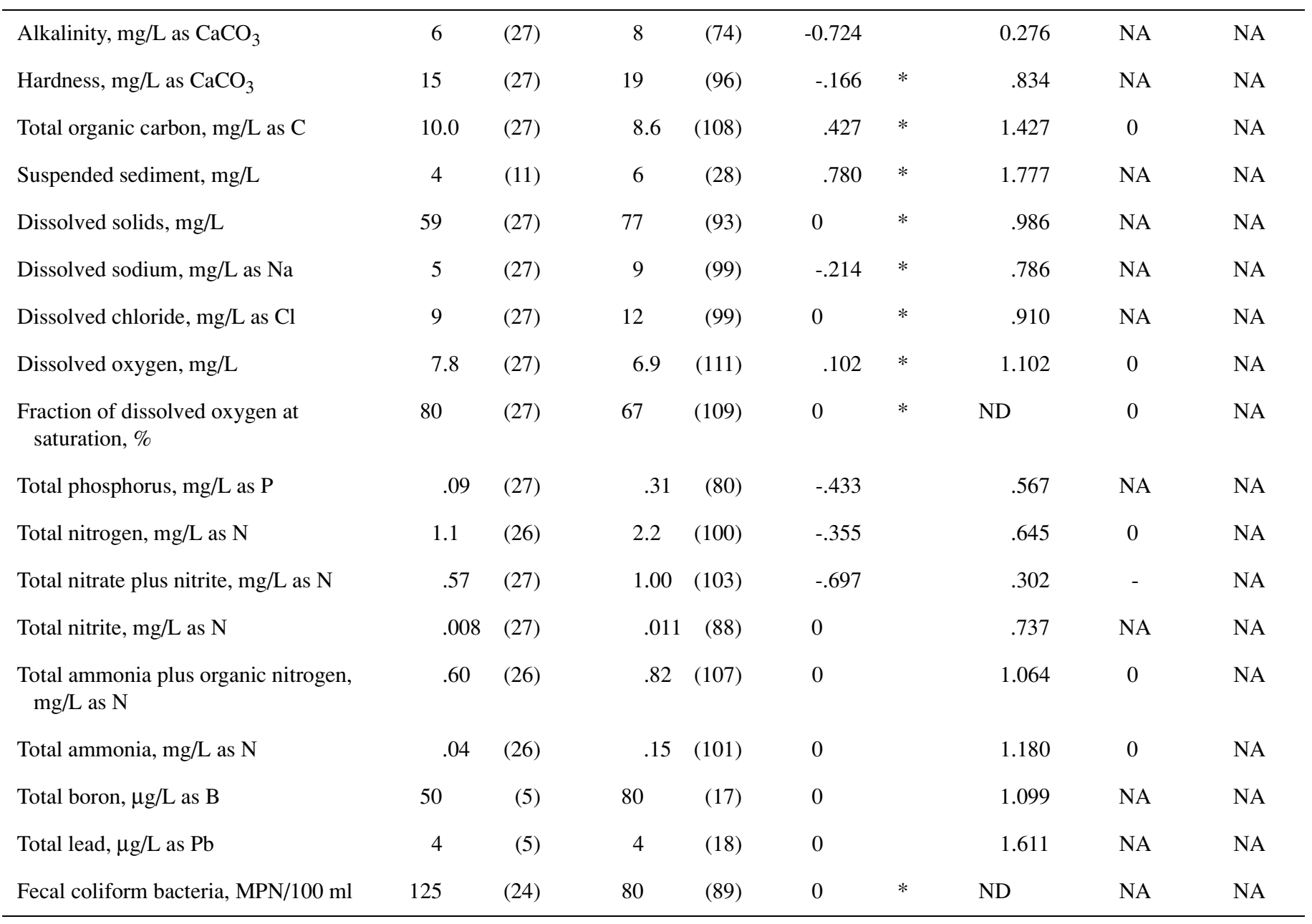

Table 13b. 1993 AMNET impairment status in the vicinity of water-quality station 01410784, Great Egg Harbor River near Sicklerville, N.J.

[AMNET, Ambient Biomonitoring Network; WQ, water-quality. Upstream from WQ station is within 5 miles upstream from the WQ station; at WQ-station location is within 0.5 mile upstream or downstream from the WQ station; downstream from WQ station is within 5 miles downstream from the WQ station; ND, undetermined impairment status]

\begin{tabular}{lccr}
\hline & Upstream from WQ station & At WQ-station location & Downstream from WQ station \\
\hline AMNET station & AN0620 & AN0621 & AN0623 \\
Impairment status & Moderately impaired & Non-impaired & Non-impaired \\
\hline
\end{tabular}


Table 14a. Median concentrations, relations of concentration and load to streamflow, and directions of concentration trends for selected waterquality constituents at water-quality station 01411000, Great Egg Harbor River at Folsom, N.J.

[Number in parenthesis is the number of available data values; WY, water years; $\mathrm{mg} / \mathrm{L}$, milligrams per liter; $\mathrm{CaCO}_{3}$, calcium carbonate; $\mathrm{C}$, carbon; Na, sodium; $\mathrm{Cl}$, chloride; \%, percent; $\mathrm{P}$, phosphorus; $\mathrm{N}$, nitrogen; $\mu \mathrm{g} / \mathrm{L}$, micrograms per liter; $\mathrm{B}$, boron; $\mathrm{Pb}$, lead; MPN/100 mL, most probable number per 100 milliliters. Regression slopes and trend directions are zero when the slope is not different from zero at the 0.05 significance level; * indicates seasonal dependency (the slope and (or) intercept of growing (April through October) and non-growing (November through March) season data were different at the 0.05 significance level); +, positive trend direction; -, negative trend direction; NA, insufficient data for analysis; ND, undetermined value]

\begin{tabular}{|c|c|c|c|c|c|c|c|c|c|}
\hline \multirow[b]{2}{*}{ Constituent } & \multicolumn{2}{|c|}{ 1989-93 WY } & \multicolumn{7}{|c|}{ 1976-93 WY } \\
\hline & \multicolumn{2}{|c|}{$\begin{array}{c}\text { Median } \\
\text { concentration }\end{array}$} & \multicolumn{2}{|c|}{$\begin{array}{l}\text { Median } \\
\text { concentration }\end{array}$} & \multicolumn{2}{|c|}{$\begin{array}{c}\text { Regression } \\
\text { slope of } \\
\text { concentration to } \\
\text { streamflow }\end{array}$} & \multirow{2}{*}{$\begin{array}{c}\begin{array}{c}\text { Regression } \\
\text { slope of } \\
\text { load to } \\
\text { streamflow }\end{array} \\
0\end{array}$} & \multirow{2}{*}{$\begin{array}{c}\begin{array}{c}\text { Low- } \\
\text { flow } \\
\text { trend } \\
\text { direction }\end{array} \\
\text { NA }\end{array}$} & \multirow{2}{*}{$\begin{array}{c}\begin{array}{c}\text { High- } \\
\text { flow } \\
\text { trend } \\
\text { direction }\end{array} \\
\text { NA }\end{array}$} \\
\hline Alkalinity, $\mathrm{mg} / \mathrm{L}$ as $\mathrm{CaCO}_{3}$ & 5 & $(11)$ & 5 & $(11)$ & -0.822 & & & & \\
\hline Hardness, $\mathrm{mg} / \mathrm{L}$ as $\mathrm{CaCO}_{3}$ & 11 & $(12)$ & 14 & $(65)$ & 0 & & 1.062 & 0 & NA \\
\hline Total organic carbon, $\mathrm{mg} / \mathrm{L}$ as $\mathrm{C}$ & 4.3 & $(11)$ & 9.0 & (33) & .653 & & 1.652 & NA & NA \\
\hline Suspended sediment, $\mathrm{mg} / \mathrm{L}$ & 5 & $(10)$ & 6 & (18) & 0 & & 1.035 & NA & NA \\
\hline Dissolved solids, mg/L & 39 & $(11)$ & 60 & $(35)$ & .159 & & 1.158 & NA & NA \\
\hline Dissolved sodium, $\mathrm{mg} / \mathrm{L}$ as $\mathrm{Na}$ & 5 & $(12)$ & 7 & $(67)$ & -.267 & & .733 & - & NA \\
\hline Dissolved chloride, $\mathrm{mg} / \mathrm{L}$ as $\mathrm{Cl}$ & 8 & (13) & 11 & $(72)$ & -.129 & & .871 & - & NA \\
\hline Dissolved oxygen, $\mathrm{mg} / \mathrm{L}$ & 8.6 & $(20)$ & 8.8 & $(114)$ & 0 & $*$ & .993 & 0 & NA \\
\hline $\begin{array}{l}\text { Fraction of dissolved oxygen at } \\
\text { saturation, } \%\end{array}$ & 80 & $(20)$ & 84 & (113) & -.106 & $*$ & ND & 0 & NA \\
\hline Total phosphorus, $\mathrm{mg} / \mathrm{L}$ as $\mathrm{P}$ & .07 & $(21)$ & .09 & (63) & 0 & $*$ & 1.176 & NA & NA \\
\hline Total nitrogen, $\mathrm{mg} / \mathrm{L}$ as $\mathrm{N}$ & 1.3 & $(21)$ & 1.5 & (94) & -.155 & & .845 & 0 & NA \\
\hline Total nitrate plus nitrite, $\mathrm{mg} / \mathrm{L}$ as $\mathrm{N}$ & .73 & $(21)$ & .85 & (97) & -.613 & $*$ & .387 & 0 & NA \\
\hline Total nitrite, $\mathrm{mg} / \mathrm{L}$ as $\mathrm{N}$ & .008 & $(20)$ & .007 & (96) & 0 & & 1.073 & 0 & NA \\
\hline $\begin{array}{l}\text { Total ammonia plus organic nitrogen, } \\
\mathrm{mg} / \mathrm{L} \text { as } \mathrm{N}\end{array}$ & .61 & $(21)$ & .64 & $(111)$ & .200 & & 1.200 & - & NA \\
\hline Total ammonia, $\mathrm{mg} / \mathrm{L}$ as $\mathrm{N}$ & .09 & $(21)$ & .16 & (96) & -.415 & & .584 & 0 & NA \\
\hline Total boron, $\mu \mathrm{g} / \mathrm{L}$ as $\mathrm{B}$ & 40 & (2) & 50 & (3) & ND & & ND & NA & NA \\
\hline Total lead, $\mu \mathrm{g} / \mathrm{L}$ as $\mathrm{Pb}$ & 2 & (4) & 6 & $(38)$ & 0 & & 1.149 & NA & NA \\
\hline Fecal coliform bacteria, MPN/100 ml & 27 & $(21)$ & 20 & $(113)$ & .907 & $*$ & ND & + & NA \\
\hline
\end{tabular}

Table 14b. 1993 AMNET impairment status in the vicinity of water-quality station 01411000, Great Egg Harbor River at Folsom, N.J.

[AMNET, Ambient Biomonitoring Network; WQ, water-quality. Upstream from WQ station is within 5 miles upstream from the WQ station; at WQ-station location is within 0.5 mile upstream or downstream from the WQ station; downstream from WQ station is within 5 miles downstream from the WQ station; ND, undetermined impairment status]

\begin{tabular}{lccr}
\hline & Upstream from WQ station & At WQ-station location & Downstream from WQ station \\
\hline AMNET station & AN0623 & AN0625 & AN0635 \\
Impairment status & Non-impaired & Non-impaired & Non-impaired \\
\hline
\end{tabular}


Table 15a. Median concentrations, relations of concentration and load to streamflow, and directions of concentration trends for selected waterquality constituents at water-quality station 01411110, Great Egg Harbor River at Weymouth, N.J.

[Number in parenthesis is the number of available data values; WY, water years; $\mathrm{mg} / \mathrm{L}$, milligrams per liter; $\mathrm{CaCO}_{3}$, calcium carbonate; $\mathrm{C}$, carbon; Na, sodium; $\mathrm{Cl}$, chloride; \%, percent; $\mathrm{P}$, phosphorus; $\mathrm{N}$, nitrogen; $\mu \mathrm{g} / \mathrm{L}$, micrograms per liter; $\mathrm{B}$, boron; Pb, lead; MPN/100 mL, most probable number per 100 milliliters. Regression slopes and trend directions are zero when the slope is not different from zero at the 0.05 significance level; * indicates seasonal dependency (the slope and (or) intercept of growing (April through October) and non-growing (November through March) season data were different at the 0.05 significance level); +, positive trend direction; -, negative trend direction; NA, insufficient data for analysis; ND, undetermined value]

\begin{tabular}{|c|c|c|c|c|c|c|}
\hline \multirow[b]{2}{*}{ Constituent } & \multirow{2}{*}{$\begin{array}{c}\text { 1989-93 WY } \\
\text { Median } \\
\text { concentration }\end{array}$} & \multicolumn{5}{|c|}{ 1976-93 WY } \\
\hline & & $\begin{array}{c}\text { Median } \\
\text { concentration }\end{array}$ & $\begin{array}{c}\text { Regression } \\
\text { slope of } \\
\text { concentration to } \\
\text { streamflow }\end{array}$ & $\begin{array}{l}\text { Regression } \\
\text { slope of } \\
\text { load to } \\
\text { streamflow }\end{array}$ & $\begin{array}{l}\text { Low- } \\
\text { flow } \\
\text { trend } \\
\text { direction }\end{array}$ & $\begin{array}{l}\text { High- } \\
\text { flow } \\
\text { trend } \\
\text { direction }\end{array}$ \\
\hline
\end{tabular}

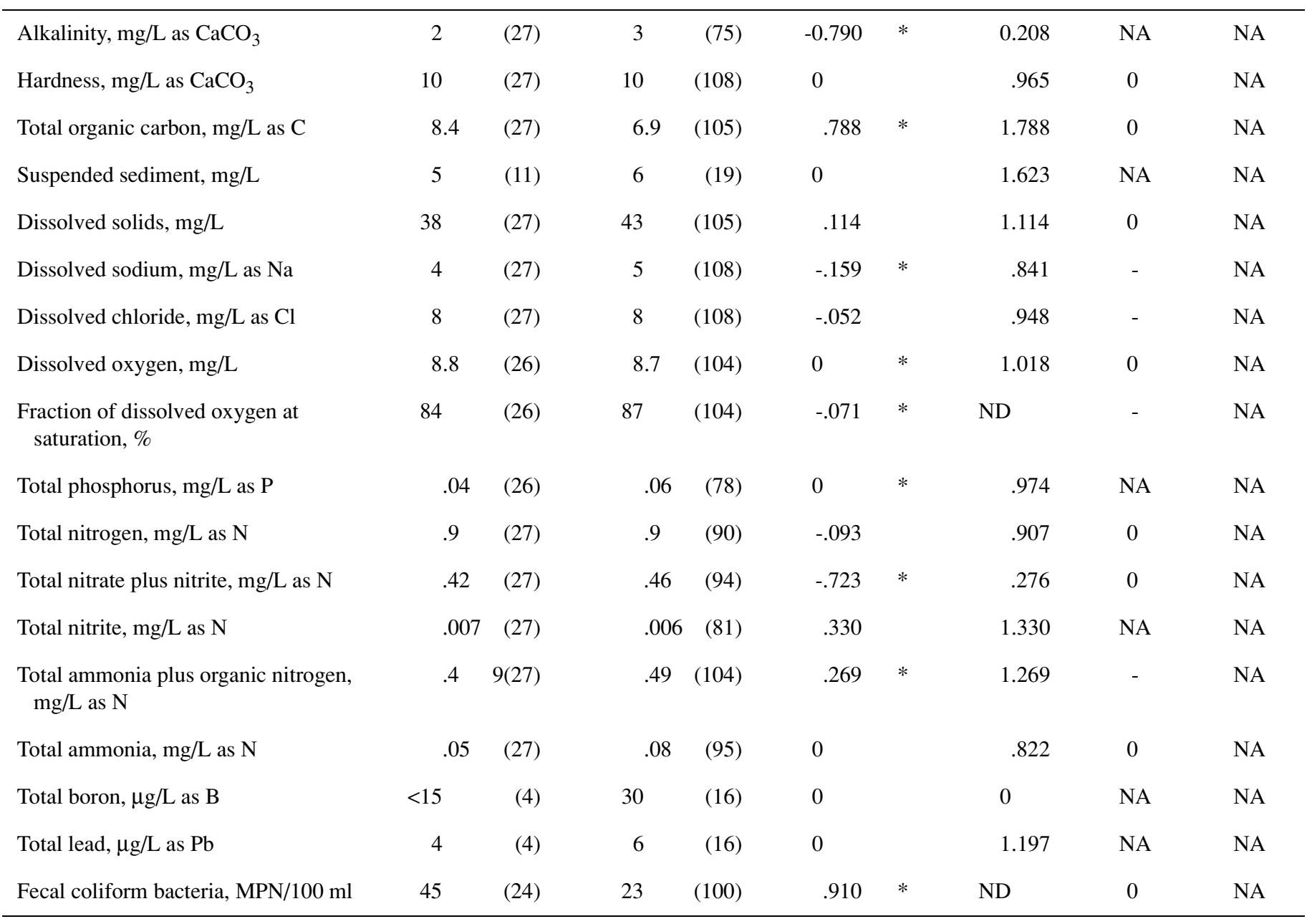

Table 15b. 1993 AMNET impairment status in the vicinity of water-quality station 01411110, Great Egg Harbor River at Weymouth, N.J.

[AMNET, Ambient Biomonitoring Network; WQ, water-quality. Upstream from WQ station is within 5 miles upstream from the WQ station; at WQ-station location is within 0.5 mile upstream or downstream from the WQ station; downstream from WQ station is within 5 miles downstream from the WQ station; ND, undetermined impairment status]

\begin{tabular}{lccc}
\hline & Upstream from WQ station & At WQ-station location & Downstream from WQ station \\
\hline AMNET station & AN0625 & AN0635 & None \\
Impairment status & Non-impaired & Non-impaired & ND \\
\hline
\end{tabular}


the smallest for these constituents in the study area. The load slopes of TOC, TN, NO2, and TAON increase in the downstream direction, indicating an increase in the contributions of these constituents from storm runoff along the Great Egg Harbor River.

Only BACT at station 01411000 has a positive trend during low flow, indicating an increase in the contributions of BACT from point sources and ground water over time. During low flows, trends are negative for NO32 at station 01410784 , for NA, CL, and TAON at station 01411000, and for NA, CL, FDO, and TAON at station 01411110, indicating a decrease in the contributions of these constituents from point sources and ground water over time. The trends are insignificant for TOC, DO, FDO, TN, TAON, and NH4 at station 01410784, for HARD, DO, FDO, TN, NO32, NO2, and NH4 at station 01411000, and for HARD, TOC, DS, DO, TN, NO32, $\mathrm{NH} 4$, and BACT at station 01411110 during low flows. Insufficient data are available to determine trends for all constituents during high flows at all stations on the Great Egg Harbor River.

The AMNET impairment status is non-impaired at station 01410784 and moderately impaired upstream and downstream from the station (table 13b). The AMNET impairment status is non-impaired at and upstream and downstream from station 01411000 (table 14b). The AMNET impairment status is non-impaired at and upstream from station 01411110 (table 15b).

\section{Lower Delaware River Basin}

Fourteen water-quality stations are located in nine subbasins in the lower Delaware River Basin. Two stations are located on the Assunpink Creek, two in the Crosswicks Creek Basin, three in the Rancocas Creek Basin, two in the Pennsauken Creek Basin, one each on the Cooper River, South Branch Big Timber Creek, Raccoon Creek, Oldmans Creek, and Salem River.

\section{$\underline{\text { Assunpink Creek }}$}

Two water-quality stations are located on the Assunpink Creek-stations 01463620 near Clarksville and 01464000 at Trenton. The 5-year and period-of-record medians are similar for all constituents at station 01463620 (table 16a). The 5-year medians are smaller for NO2, TAON, and NH4 and greater for NO32 compared to the period-of-record medians at station 01464000 (table 17a). At station 01463620, the period-of-record median for FDO is the largest and for PB the smallest for these constituents at all stations in the study area. At station 01464000, the period-of-record median for ALK is the largest for this constituent at all stations in the study area. The regression slopes of concentration to streamflow for ALK, TOC, NA, CL, DO, TN, NO32, and TAON show seasonal dependency at station 01463620. The concentration slopes for CL, DO, FDO, NO2, and BACT show seasonal dependency at station 01464000.

The regression slopes of load to streamflow are in the high range for NA and NO2 at station 01463620 , indicating greater contributions of these constituents from storm runoff relative to that at other sites in the study area. Load slopes are in the low range for TOC at station 01463620 and for HARD, DS, NA, CL, TP, TN, NO32, and TAON at station 01464000, indicating smaller contributions of these constituents from storm runoff relative to that at other sites in the study area. The load slopes for DS and CL at station 01464000 are the smallest for 
Table 16a. Median concentrations, relations of concentration and load to streamflow, and directions of concentration trends for selected waterquality constituents at water-quality station 01463620, Assunpink Creek near Clarksville, N.J.

[Number in parenthesis is the number of available data values; WY, water years; $\mathrm{mg} / \mathrm{L}$, milligrams per liter; $\mathrm{CaCO}_{3}$, calcium carbonate; $\mathrm{C}$, carbon; Na, sodium; $\mathrm{Cl}$, chloride; \%, percent; $\mathrm{P}$, phosphorus; $\mathrm{N}$, nitrogen; $\mu \mathrm{g} / \mathrm{L}$, micrograms per liter; $\mathrm{B}$, boron; Pb, lead; MPN/100 mL, most probable number per 100 milliliters. Regression slopes and trend directions are zero when the slope is not different from zero at the 0.05 significance level; * indicates seasonal dependency (the slope and (or) intercept of growing (April through October) and non-growing (November through March) season data were different at the 0.05 significance level); +, positive trend direction; -, negative trend direction; NA, insufficient data for analysis; ND, undetermined value]

\begin{tabular}{|c|c|c|c|c|c|c|}
\hline \multirow[b]{2}{*}{ Constituent } & \multirow{2}{*}{$\begin{array}{c}\text { 1989-93 WY } \\
\text { Median } \\
\text { concentration }\end{array}$} & \multicolumn{5}{|c|}{ 1976-93 WY } \\
\hline & & $\begin{array}{c}\text { Median } \\
\text { concentration }\end{array}$ & $\begin{array}{l}\text { Regression } \\
\text { slope of } \\
\text { concentration to } \\
\text { streamflow }\end{array}$ & $\begin{array}{l}\text { Regression } \\
\text { slope of } \\
\text { load to } \\
\text { streamflow }\end{array}$ & $\begin{array}{l}\text { Low- } \\
\text { flow } \\
\text { trend } \\
\text { direction }\end{array}$ & $\begin{array}{l}\text { High- } \\
\text { flow } \\
\text { trend } \\
\text { direction }\end{array}$ \\
\hline
\end{tabular}

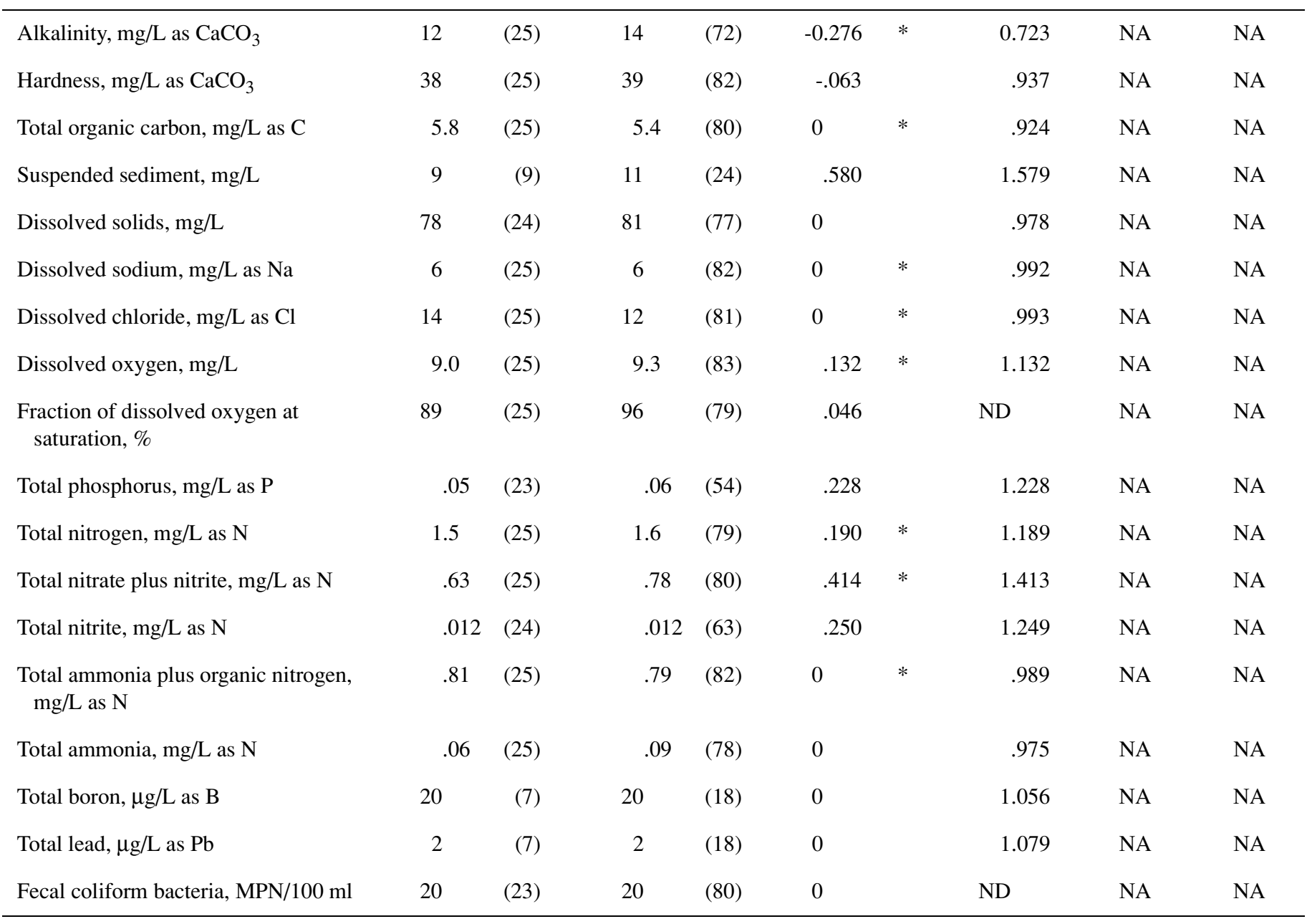

Table 16b. 1993 AMNET impairment status in the vicinity of water-quality station 01463620, Assunpink Creek near Clarksville, N.J.

[AMNET, Ambient Biomonitoring Network; WQ, water-quality. Upstream from WQ station is within 5 miles upstream from the WQ station; at WQ-station location is within 0.5 mile upstream or downstream from the WQ station; downstream from WQ station is within 5 miles downstream from the WQ station; ND, undetermined impairment status]

\begin{tabular}{lccc}
\hline & Upstream from WQ station & At WQ-station location & Downstream from WQ station \\
\hline AMNET station & AN0109 & None & AN0116 \\
Impairment status & Non-impaired & ND & Moderately impaired \\
\hline
\end{tabular}


Table 17a. Median concentrations, relations of concentration and load to streamflow, and directions of concentration trends for selected waterquality constituents at water-quality station 01464000, Assunpink Creek at Trenton, N.J.

[Number in parenthesis is the number of available data values; WY, water years; $\mathrm{mg} / \mathrm{L}$, milligrams per liter; $\mathrm{CaCO}_{3}$, calcium carbonate; $\mathrm{C}$, carbon; Na, sodium; $\mathrm{Cl}$, chloride; \%, percent; $\mathrm{P}$, phosphorus; $\mathrm{N}$, nitrogen; $\mu \mathrm{g} / \mathrm{L}$, micrograms per liter; $\mathrm{B}$, boron; $\mathrm{Pb}$, lead; MPN/100 mL, most probable number per 100 milliliters. Regression slopes and trend directions are zero when the slope is not different from zero at the 0.05 significance level; * indicates seasonal dependency (the slope and (or) intercept of growing (April through October) and non-growing (November through March) season data were different at the 0.05 significance level); +, positive trend direction; -, negative trend direction; NA, insufficient data for analysis; ND, undetermined value]

\begin{tabular}{|c|c|c|c|c|c|c|c|c|c|}
\hline \multirow{3}{*}{$\begin{array}{c}\text { Constituent } \\
\text { nity, } \mathrm{mg} / \mathrm{L} \text { as } \mathrm{CaCO}_{3}\end{array}$} & \multirow{2}{*}{\multicolumn{2}{|c|}{$\begin{array}{c}\text { 1989-93 WY } \\
\text { Median } \\
\text { concentration }\end{array}$}} & \multicolumn{7}{|c|}{ 1976-93 WY } \\
\hline & & & $\begin{array}{r}\text { Medi } \\
\text { concentr }\end{array}$ & $\begin{array}{l}\text { ian } \\
\text { ration }\end{array}$ & \multicolumn{2}{|c|}{$\begin{array}{l}\text { Regression } \\
\text { slope of } \\
\text { concentration to } \\
\text { streamflow }\end{array}$} & \multirow{2}{*}{$\begin{array}{c}\begin{array}{c}\text { Regression } \\
\text { slope of } \\
\text { load to } \\
\text { streamflow }\end{array} \\
0.633\end{array}$} & \multirow{2}{*}{$\begin{array}{c}\begin{array}{c}\text { Low- } \\
\text { flow } \\
\text { trend } \\
\text { direction }\end{array} \\
\text { NA }\end{array}$} & \multirow{2}{*}{$\begin{array}{c}\begin{array}{c}\text { High- } \\
\text { flow } \\
\text { trend } \\
\text { direction }\end{array} \\
\text { NA }\end{array}$} \\
\hline & 42 & (11) & 42 & (11) & -0.367 & & & & \\
\hline Hardness, $\mathrm{mg} / \mathrm{L}$ as $\mathrm{CaCO}_{3}$ & 79 & (13) & 71 & (63) & -.259 & & .741 & NA & NA \\
\hline Total organic carbon, $\mathrm{mg} / \mathrm{L}$ as $\mathrm{C}$ & 5.3 & (7) & 6.6 & $(30)$ & 0 & & 1.102 & NA & NA \\
\hline Suspended sediment, $\mathrm{mg} / \mathrm{L}$ & 9 & (11) & 12 & $(21)$ & .837 & & 1.837 & NA & NA \\
\hline Dissolved solids, mg/L & 182 & (11) & 173 & (36) & -.260 & & .739 & NA & NA \\
\hline Dissolved sodium, $\mathrm{mg} / \mathrm{L}$ as $\mathrm{Na}$ & 25 & (13) & 20 & $(65)$ & -.387 & & .613 & NA & NA \\
\hline Dissolved chloride, $\mathrm{mg} / \mathrm{L}$ as $\mathrm{Cl}$ & 34 & (13) & 29 & $(70)$ & -.365 & $*$ & .635 & NA & NA \\
\hline Dissolved oxygen, $\mathrm{mg} / \mathrm{L}$ & 10.0 & $(21)$ & 8.7 & (109) & .149 & $*$ & 1.149 & NA & 0 \\
\hline $\begin{array}{l}\text { Fraction of dissolved oxygen at } \\
\text { saturation, } \%\end{array}$ & 95 & (18) & 88 & $(101)$ & .078 & $*$ & ND & NA & 0 \\
\hline Total phosphorus, $\mathrm{mg} / \mathrm{L}$ as $\mathrm{P}$ & .30 & $(21)$ & .50 & $(61)$ & -.340 & & .659 & NA & NA \\
\hline Total nitrogen, $\mathrm{mg} / \mathrm{L}$ as $\mathrm{N}$ & 4.0 & $(21)$ & 4.0 & $(100)$ & -.336 & & .664 & NA & NA \\
\hline Total nitrate plus nitrite, $\mathrm{mg} / \mathrm{L}$ as $\mathrm{N}$ & 3.17 & $(21)$ & 1.80 & $(101)$ & -.392 & & 608 & NA & 0 \\
\hline Total nitrite, $\mathrm{mg} / \mathrm{L}$ as $\mathrm{N}$ & .022 & $(20)$ & .036 & (90) & -.432 & $*$ & .568 & NA & - \\
\hline $\begin{array}{l}\text { Total ammonia plus organic nitrogen, } \\
\mathrm{mg} / \mathrm{L} \text { as } \mathrm{N}\end{array}$ & .90 & $(21)$ & 1.60 & (109) & -.212 & & .788 & NA & NA \\
\hline Total ammonia, $\mathrm{mg} / \mathrm{L}$ as $\mathrm{N}$ & .08 & $(21)$ & .76 & (96) & 0 & & .816 & NA & NA \\
\hline Total boron, $\mu \mathrm{g} / \mathrm{L}$ as $\mathrm{B}$ & 100 & (3) & 120 & (4) & ND & & ND & NA & NA \\
\hline Total lead, $\mu \mathrm{g} / \mathrm{L}$ as $\mathrm{Pb}$ & 4 & $(5)$ & 13 & $(37)$ & .475 & & 1.474 & NA & NA \\
\hline Fecal coliform bacteria, MPN/100 ml & 3500 & $(21)$ & 1300 & $(110)$ & 0 & $*$ & ND & NA & 0 \\
\hline
\end{tabular}

Table 17b. 1993 AMNET impairment status in the vicinity of water-quality station 01464000, Assunpink Creek at Trenton, N.J.

[AMNET, Ambient Biomonitoring Network; WQ, water-quality. Upstream from WQ station is within 5 miles upstream from the WQ station; at WQ-station location is within 0.5 mile upstream or downstream from the WQ station; downstream from WQ station is within 5 miles downstream from the WQ station; ND, undetermined impairment status]

\begin{tabular}{lccc}
\hline & Upstream from WQ station & At WQ-station location & Downstream from WQ station \\
\hline AMNET station & AN0116 & None & AN0118 \\
Impairment status & Moderately impaired & ND & Moderately impaired \\
\hline
\end{tabular}


these constituents in the study area. The load slopes for HARD, DS, NA, CL, TP, TN, NO32, $\mathrm{NO} 2$, TAON, and NH4 decrease in the downstream direction, indicating a decrease in the contributions of these constituents from storm runoff along the Assunpink Creek.

Insufficient data are available to determine trends for all constituents at station 01463620 during low and high flows. During high flows at station 01464000, trends are insignificant for $\mathrm{DO}, \mathrm{FDO}, \mathrm{NO} 32$, and BACT; the trend is negative for NO2, indicating a decrease in the contribution of NO2 from storm runoff over time. Insufficient data are available at station 01464000 to determine trends for all constituents during low flows.

The AMNET impairment status is non-impaired upstream from and moderately impaired downstream from station 01463620 (table 16b). The AMNET impairment status upstream and downstream from station 01464000 is moderately impaired (table 17b).

\section{Crosswicks Creek}

The Crosswicks Creek Basin has two water-quality stations-stations 01464500 on Crosswicks Creek at Extonville and 01464515 on Doctors Creek at Allentown. The 5-year medians are smaller than the period-of-record medians for TP, TN, NO32, NO2, TAON, and NH4 at station 01464500; 5-year and period-of-record medians are similar for all other constituents (table 18a). The 5-year and period-of-record medians are similar for all constituents at station 01464515 (table 19a). At both stations, the period-of-record medians for PB are the smallest for $\mathrm{PB}$ at all stations in the study area. At station 01464500 , the regression slopes of concentration to streamflow for ALK, HARD, TOC, DO, FDO, NO32, NO2, TAON, NH4, and BACT show seasonal dependency. The concentration slopes for ALK, HARD, TOC, NA, CL, DO, FDO, TN, NO32, NH4, and BACT show seasonal dependency at station 01464515.

The regression slopes of load to streamflow are in the high range for SS and PB at station 01464500 and for ALK at station 01464515, indicating greater contributions of these constituents from storm runoff relative to that at other sites in the study area. Load slopes are in the low range for HARD, DS, NA, TN, NO32, and B at station 01464500 and for TOC, TAON, NH4, and B at station 01464515 , indicating smaller contributions of these constituents from storm runoff relative to that at other sites in the study area.

During low flows, trends are positive for CL at station 01464500 and NA at station 01464515, indicating an increase in the contributions of these constituents from point sources and ground water over time, and negative for TAON at station 01464500 and NH4 at station 01464515, indicating a decrease in the contributions of these constituents from storm runoff over time. Trends are insignificant during low flows for HARD, TOC, DS, DO, FDO, TN, NO32, and BACT at both stations, for NA and NH4 at station 01464500, and for CL and TAON at station 01464515. Insufficient data are available at both stations to determine trends for all other constituents during low flows and for all constituents during high flows.

The AMNET impairment status is severely impaired at station 01464500 and moderately impaired downstream from the station (table 18b). The AMNET impairment status is moderately impaired at station 01464515 and non-impaired downstream from the station (table 19b). 
Table 18a. Median concentrations, relations of concentration and load to streamflow, and directions of concentration trends for selected waterquality constituents at water-quality station 01464500, Crosswicks Creek at Extonville, N.J.

[Number in parenthesis is the number of available data values; WY, water years; $\mathrm{mg} / \mathrm{L}$, milligrams per liter; $\mathrm{CaCO}_{3}$, calcium carbonate; $\mathrm{C}$, carbon; Na, sodium; $\mathrm{Cl}$, chloride; \%, percent; $\mathrm{P}$, phosphorus; $\mathrm{N}$, nitrogen; $\mu \mathrm{g} / \mathrm{L}$, micrograms per liter; $\mathrm{B}$, boron; $\mathrm{Pb}$, lead; MPN/100 mL, most probable number per 100 milliliters. Regression slopes and trend directions are zero when the slope is not different from zero at the 0.05 significance level; * indicates seasonal dependency (the slope and (or) intercept of growing (April through October) and non-growing (November through March) season data were different at the 0.05 significance level); +, positive trend direction; -, negative trend direction; NA, insufficient data for analysis; ND, undetermined value]

\begin{tabular}{|c|c|c|c|c|c|c|c|c|c|}
\hline \multirow{3}{*}{$\begin{array}{l}\text { Constituent } \\
\text { ag/L as } \mathrm{CaCO}_{3}\end{array}$} & \multicolumn{2}{|c|}{ 1989-93 WY } & \multicolumn{7}{|c|}{ 1976-93 WY } \\
\hline & \multicolumn{2}{|c|}{$\begin{array}{c}\text { Median } \\
\text { concentration }\end{array}$} & \multicolumn{2}{|c|}{$\begin{array}{c}\text { Median } \\
\text { concentration }\end{array}$} & \multicolumn{2}{|c|}{$\begin{array}{c}\text { Regression } \\
\text { slope of } \\
\text { concentration to } \\
\text { streamflow }\end{array}$} & \multirow{2}{*}{$\begin{array}{c}\begin{array}{c}\text { Regression } \\
\text { slope of } \\
\text { load to } \\
\text { streamflow }\end{array} \\
0.609\end{array}$} & \multirow{2}{*}{$\begin{array}{c}\text { Low- } \\
\text { flow } \\
\text { trend } \\
\text { direction } \\
\text { NA }\end{array}$} & \multirow{2}{*}{$\begin{array}{c}\text { High- } \\
\text { flow } \\
\text { trend } \\
\text { direction } \\
\text { NA }\end{array}$} \\
\hline & 19 & $(27)$ & 21 & (75) & -0.391 & $*$ & & & \\
\hline Hardness, $\mathrm{mg} / \mathrm{L}$ as $\mathrm{CaCO}_{3}$ & 49 & (26) & 48 & $(110)$ & -.204 & $*$ & .796 & 0 & NA \\
\hline Total organic carbon, $\mathrm{mg} / \mathrm{L}$ as $\mathrm{C}$ & 5.4 & (26) & 5.9 & $(108)$ & .168 & $*$ & 1.168 & 0 & NA \\
\hline Suspended sediment, $\mathrm{mg} / \mathrm{L}$ & 8 & (11) & 11 & $(28)$ & 1.198 & & 2.196 & NA & NA \\
\hline Dissolved solids, $\mathrm{mg} / \mathrm{L}$ & 102 & (26) & 102 & (106) & -.199 & & .801 & 0 & NA \\
\hline Dissolved sodium, $\mathrm{mg} / \mathrm{L}$ as $\mathrm{Na}$ & 8 & $(27)$ & 8 & $(111)$ & -.298 & & .702 & 0 & NA \\
\hline Dissolved chloride, $\mathrm{mg} / \mathrm{L}$ as $\mathrm{Cl}$ & 16 & $(27)$ & 13 & $(111)$ & -.203 & & .797 & + & NA \\
\hline Dissolved oxygen, $\mathrm{mg} / \mathrm{L}$ & 7.8 & $(27)$ & 7.3 & $(108)$ & .084 & $*$ & 1.084 & 0 & NA \\
\hline $\begin{array}{l}\text { Fraction of dissolved oxygen at } \\
\text { saturation, } \%\end{array}$ & 83 & $(27)$ & 78 & (108) & 0 & $*$ & ND & 0 & NA \\
\hline Total phosphorus, $\mathrm{mg} / \mathrm{L}$ as $\mathrm{P}$ & .17 & $(27)$ & .23 & $(106)$ & .202 & & 1.202 & NA & NA \\
\hline Total nitrogen, $\mathrm{mg} / \mathrm{L}$ as $\mathrm{N}$ & 1.7 & $(27)$ & 2.0 & $(101)$ & -.170 & & .830 & 0 & NA \\
\hline Total nitrate plus nitrite, $\mathrm{mg} / \mathrm{L}$ as $\mathrm{N}$ & .85 & $(27)$ & 1.00 & $(102)$ & -.323 & $*$ & 677 & 0 & NA \\
\hline Total nitrite, $\mathrm{mg} / \mathrm{L}$ as $\mathrm{N}$ & .031 & $(27)$ & .042 & $(80)$ & -.440 & $*$ & .559 & NA & NA \\
\hline $\begin{array}{l}\text { Total ammonia plus organic nitrogen, } \\
\mathrm{mg} / \mathrm{L} \text { as } \mathrm{N}\end{array}$ & .75 & $(27)$ & .99 & (109) & 0 & $*$ & .969 & - & NA \\
\hline Total ammonia, $\mathrm{mg} / \mathrm{L}$ as $\mathrm{N}$ & .18 & $(27)$ & .30 & $(101)$ & 0 & $*$ & .986 & 0 & NA \\
\hline Total boron, $\mu \mathrm{g} / \mathrm{L}$ as $\mathrm{B}$ & 30 & (6) & 40 & (18) & 0 & & 0 & NA & NA \\
\hline Total lead, $\mu \mathrm{g} / \mathrm{L}$ as $\mathrm{Pb}$ & 1 & $(6)$ & 2 & (19) & 1.942 & & 2.942 & NA & NA \\
\hline Fecal coliform bacteria, MPN/100 ml & 330 & $(25)$ & 240 & $(107)$ & .687 & $*$ & ND & 0 & NA \\
\hline
\end{tabular}

Table 18b. 1993 AMNET impairment status in the vicinity of water-quality station 01464500, Crosswicks Creek at Extonville, N.J.

[AMNET, Ambient Biomonitoring Network; WQ, water-quality. Upstream from WQ station is within 5 miles upstream from the WQ station; at WQ-station location is within 0.5 mile upstream or downstream from the WQ station; downstream from WQ station is within 5 miles downstream from the WQ station; ND, undetermined impairment status]

\begin{tabular}{lccc}
\hline & Upstream from WQ station & At WQ-station location & Downstream from WQ station \\
\hline AMNET station & None & AN0125 & AN0126 \\
Impairment status & ND & Severely impaired & Moderately impaired \\
\hline
\end{tabular}


Table 19a. Median concentrations, relations of concentration and load to streamflow, and directions of concentration trends for selected waterquality constituents at water-quality station 01464515, Doctors Creek at Allentown, N.J.

[Number in parenthesis is the number of available data values; WY, water years; $\mathrm{mg} / \mathrm{L}$, milligrams per liter; $\mathrm{CaCO}_{3}$, calcium carbonate; $\mathrm{C}$, carbon; Na, sodium; $\mathrm{Cl}$, chloride; \%, percent; $\mathrm{P}$, phosphorus; $\mathrm{N}$, nitrogen; $\mu \mathrm{g} / \mathrm{L}$, micrograms per liter; $\mathrm{B}$, boron; Pb, lead; MPN/100 mL, most probable number per 100 milliliters. Regression slopes and trend directions are zero when the slope is not different from zero at the 0.05 significance level; * indicates seasonal dependency (the slope and (or) intercept of growing (April through October) and non-growing (November through March) season data were different at the 0.05 significance level); +, positive trend direction; -, negative trend direction; NA, insufficient data for analysis; ND, undetermined value]

\begin{tabular}{|c|c|c|c|c|c|c|c|c|c|}
\hline \multirow{3}{*}{$\begin{array}{c}\text { Constituent } \\
\text { Alkalinity, } \mathrm{mg} / \mathrm{L} \text { as } \mathrm{CaCO}_{3}\end{array}$} & \multicolumn{2}{|c|}{ 1989-93 WY } & \multicolumn{7}{|c|}{ 1976-93 WY } \\
\hline & \multicolumn{2}{|c|}{$\begin{array}{c}\text { Median } \\
\text { concentration }\end{array}$} & \multicolumn{2}{|c|}{$\begin{array}{c}\text { Median } \\
\text { concentration }\end{array}$} & \multicolumn{2}{|c|}{$\begin{array}{l}\text { Regression } \\
\text { slope of } \\
\text { concentration to } \\
\text { streamflow }\end{array}$} & \multirow{2}{*}{$\begin{array}{c}\begin{array}{c}\text { Regression } \\
\text { slope of } \\
\text { load to } \\
\text { streamflow }\end{array} \\
0.767\end{array}$} & \multirow{2}{*}{$\begin{array}{c}\begin{array}{c}\text { Low- } \\
\text { flow } \\
\text { trend } \\
\text { direction }\end{array} \\
\text { NA }\end{array}$} & \multirow{2}{*}{$\begin{array}{l}\begin{array}{c}\text { High- } \\
\text { flow } \\
\text { trend } \\
\text { direction }\end{array} \\
\text { NA }\end{array}$} \\
\hline & 20 & $(26)$ & 21 & (73) & -0.233 & $*$ & & & \\
\hline Hardness, $\mathrm{mg} / \mathrm{L}$ as $\mathrm{CaCO}_{3}$ & 50 & $(27)$ & 50 & $(107)$ & -.094 & $*$ & .906 & 0 & NA \\
\hline Total organic carbon, $\mathrm{mg} / \mathrm{L}$ as $\mathrm{C}$ & 4.4 & $(27)$ & 4.6 & $(103)$ & 0 & $*$ & .975 & 0 & NA \\
\hline Suspended sediment, mg/L & 5 & $(11)$ & 6 & $(18)$ & .639 & & 1.638 & NA & NA \\
\hline Dissolved solids, mg/L & 97 & $(27)$ & 99 & $(105)$ & -.090 & & .910 & 0 & NA \\
\hline Dissolved sodium, $\mathrm{mg} / \mathrm{L}$ as $\mathrm{Na}$ & 7 & $(27)$ & 6 & $(107)$ & -.105 & $*$ & .895 & + & NA \\
\hline Dissolved chloride, $\mathrm{mg} / \mathrm{L}$ as $\mathrm{Cl}$ & 18 & $(27)$ & 15 & $(107)$ & -.058 & $*$ & .942 & 0 & NA \\
\hline Dissolved oxygen, $\mathrm{mg} / \mathrm{L}$ & 8.2 & (26) & 8.2 & $(106)$ & .163 & $*$ & 1.163 & 0 & NA \\
\hline $\begin{array}{l}\text { Fraction of dissolved oxygen at } \\
\text { saturation, } \%\end{array}$ & 91 & $(26)$ & 88 & $(105)$ & .094 & * & ND & 0 & NA \\
\hline Total phosphorus, $\mathrm{mg} / \mathrm{L}$ as $\mathrm{P}$ & .14 & (27) & .17 & $(80)$ & -.190 & & .810 & NA & NA \\
\hline Total nitrogen, $\mathrm{mg} / \mathrm{L}$ as $\mathrm{N}$ & 1.9 & $(27)$ & 1.9 & $(95)$ & -.069 & $*$ & .931 & 0 & NA \\
\hline Total nitrate plus nitrite, $\mathrm{mg} / \mathrm{L}$ as $\mathrm{N}$ & 1.08 & $(27)$ & .93 & (96) & 0 & * & 1.102 & 0 & NA \\
\hline Total nitrite, $\mathrm{mg} / \mathrm{L}$ as $\mathrm{N}$ & .029 & $(27)$ & .030 & $(79)$ & -.369 & & .630 & NA & NA \\
\hline $\begin{array}{l}\text { Total ammonia plus organic nitrogen, } \\
\mathrm{mg} / \mathrm{L} \text { as } \mathrm{N}\end{array}$ & .83 & $(27)$ & 1.00 & $(106)$ & -.220 & & .780 & 0 & NA \\
\hline Total ammonia, $\mathrm{mg} / \mathrm{L}$ as $\mathrm{N}$ & .29 & $(27)$ & .40 & (97) & -.512 & * & .488 & - & NA \\
\hline Total boron, $\mu \mathrm{g} / \mathrm{L}$ as $\mathrm{B}$ & 30 & (6) & 30 & (17) & -.803 & & 0 & NA & NA \\
\hline Total lead, $\mu \mathrm{g} / \mathrm{L}$ as $\mathrm{Pb}$ & $<1$ & (6) & 2 & $(18)$ & 0 & & 1.237 & NA & NA \\
\hline Fecal coliform bacteria, MPN/100 ml & 790 & $(25)$ & 480 & $(104)$ & .568 & $*$ & ND & 0 & NA \\
\hline
\end{tabular}

Table 19b. 1993 AMNET impairment status in the vicinity of water-quality station 01464515, Doctors Creek at Allentown, N.J.

[AMNET, Ambient Biomonitoring Network; WQ, water-quality. Upstream from WQ station is within 5 miles upstream from the WQ station; at WQ-station location is within 0.5 mile upstream or downstream from the WQ station; downstream from WQ station is within 5 miles downstream from the WQ station; ND, undetermined impairment status]

\begin{tabular}{lccr}
\hline & Upstream from WQ station & At WQ-station location & Downstream from WQ station \\
\hline AMNET station & None & AN0129 & AN0130 \\
Impairment status & ND & Moderately impaired & Non-impaired \\
\hline
\end{tabular}




\section{Rancocas Creek}

The Rancocas Creek Basin has three water-quality stations — stations 01465850 on the South Branch of the Rancocas Creek at Vincentown, 01467000 on the North Branch of the Rancocas Creek at Pemberton, and 01466500 on the McDonalds Branch in Lebanon State Forest. The 5-year and period-of-record medians are similar for all constituents at all stations (tables 20a, 21a, and 22a). At station 01465850, the period-of-record median for TOC is the largest for TOC in the study area. The period-of-record medians for ALK, HARD, SS, DS, NA, CL, DO, FDO, TP, TN, NO32, TAON, and NH4 at station 01466500 are the smallest for these constituents at all stations in the study area because this station on the McDonald's Branch in Lebanon State Forest represents a very small area $\left(2.35 \mathrm{mi}^{2}\right)$ and is an undeveloped watershed. The regression slopes of concentration to streamflow for HARD, TOC, NA, CL, DO, FDO, TP, NH4, TAON, and BACT at stations 01465850 and 01467000 , for NO32 at station 01465850 , and for TN and NO2 at station 01467000 show seasonal dependency. The concentration slopes for HARD, SS, NA, DO, FDO, and NO32 show seasonal dependency at station 01466500.

The regression slopes of load to streamflow are in the high range for B at station 01467000, indicating greater contributions of B relative to that at other sites in the study area. The regression slopes of load to streamflow are in the high range for TOC, DS, TN, and TAON at station 01466500 where the load slopes for all these constituents except TOC are the largest in the study area. The load slopes for DS, TN, and TAON at station 01466500 are the largest for these constituents in the study area. Load slopes are in the low range for SS, TP, TAON, and NH4 at station 10465850, for TAON and NH4 at station 01467000, and for SS at station 01466500 , indicating smaller contributions of these constituents from storm runoff relative to that at other sites in the study area.

During low flows, trends are positive for CL and NO32 at station 01465850 and for NA and CL at station 01467000, indicating an increase in the contributions of these constituents from point sources and ground water over time. During low flows, trends are negative for FDO at station 01465850 and for TAON and NH4 at station 01467000, indicating a decrease in the contributions of these constituents from storm runoff over time. Trends are insignificant during low flows for HARD, TOC, DS, NA, DO, TN, TAON, NH4, and BACT at station 01465850, for HARD, TOC, DS, DO, FDO, TN, NO32, and BACT at station 01467000, and for HARD, SS, DS, NA, CL, DO, FDO, TP, and NO32 at station 01466500. Insufficient data are available to determine trends of all other constituents at these stations during low flows. During high flows at station 01466500, trends are insignificant for SS, DS, CL, DO, FDO, TP, and NO32. Insufficient data are available for all other constituents at station 01466500 and for all constituents at stations 01465850 and 01467000 to determine trends during high flows.

The AMNET impairment status is severely impaired upstream from station 01465850 and moderately impaired downstream from the station (table 20b). The AMNET impairment status is moderately impaired at station 01466500 (table 21b). The AMNET impairment status is nonimpaired at station 01467000 and moderately impaired downstream from the station (table 22b). 
Table 20a. Median concentrations, relations of concentration and load to streamflow, and directions of concentration trends for selected waterquality constituents at water-quality station 01465850, South Branch Rancocas Creek at Vincentown, N.J.

[Number in parenthesis is the number of available data values; WY, water years; $\mathrm{mg} / \mathrm{L}$, milligrams per liter; $\mathrm{CaCO}_{3}$, calcium carbonate; $\mathrm{C}$, carbon; Na, sodium; $\mathrm{Cl}$, chloride; \%, percent; $\mathrm{P}$, phosphorus; $\mathrm{N}$, nitrogen; $\mu \mathrm{g} / \mathrm{L}$, micrograms per liter; $\mathrm{B}$, boron; Pb, lead; MPN/100 mL, most probable number per 100 milliliters. Regression slopes and trend directions are zero when the slope is not different from zero at the 0.05 significance level; * indicates seasonal dependency (the slope and (or) intercept of growing (April through October) and non-growing (November through March) season data were different at the 0.05 significance level); +, positive trend direction; -, negative trend direction; NA, insufficient data for analysis; ND, undetermined value]

\begin{tabular}{|c|c|c|c|c|c|c|}
\hline \multirow[b]{2}{*}{ Constituent } & \multirow{2}{*}{$\begin{array}{c}\text { 1989-93 WY } \\
\text { Median } \\
\text { concentration }\end{array}$} & \multicolumn{5}{|c|}{ 1976-93 WY } \\
\hline & & $\begin{array}{c}\text { Median } \\
\text { concentration }\end{array}$ & $\begin{array}{c}\text { Regression } \\
\text { slope of } \\
\text { concentration to } \\
\text { streamflow }\end{array}$ & $\begin{array}{l}\text { Regression } \\
\text { slope of } \\
\text { load to } \\
\text { streamflow }\end{array}$ & $\begin{array}{l}\text { Low- } \\
\text { flow } \\
\text { trend } \\
\text { direction }\end{array}$ & $\begin{array}{l}\text { High- } \\
\text { flow } \\
\text { trend } \\
\text { direction }\end{array}$ \\
\hline
\end{tabular}

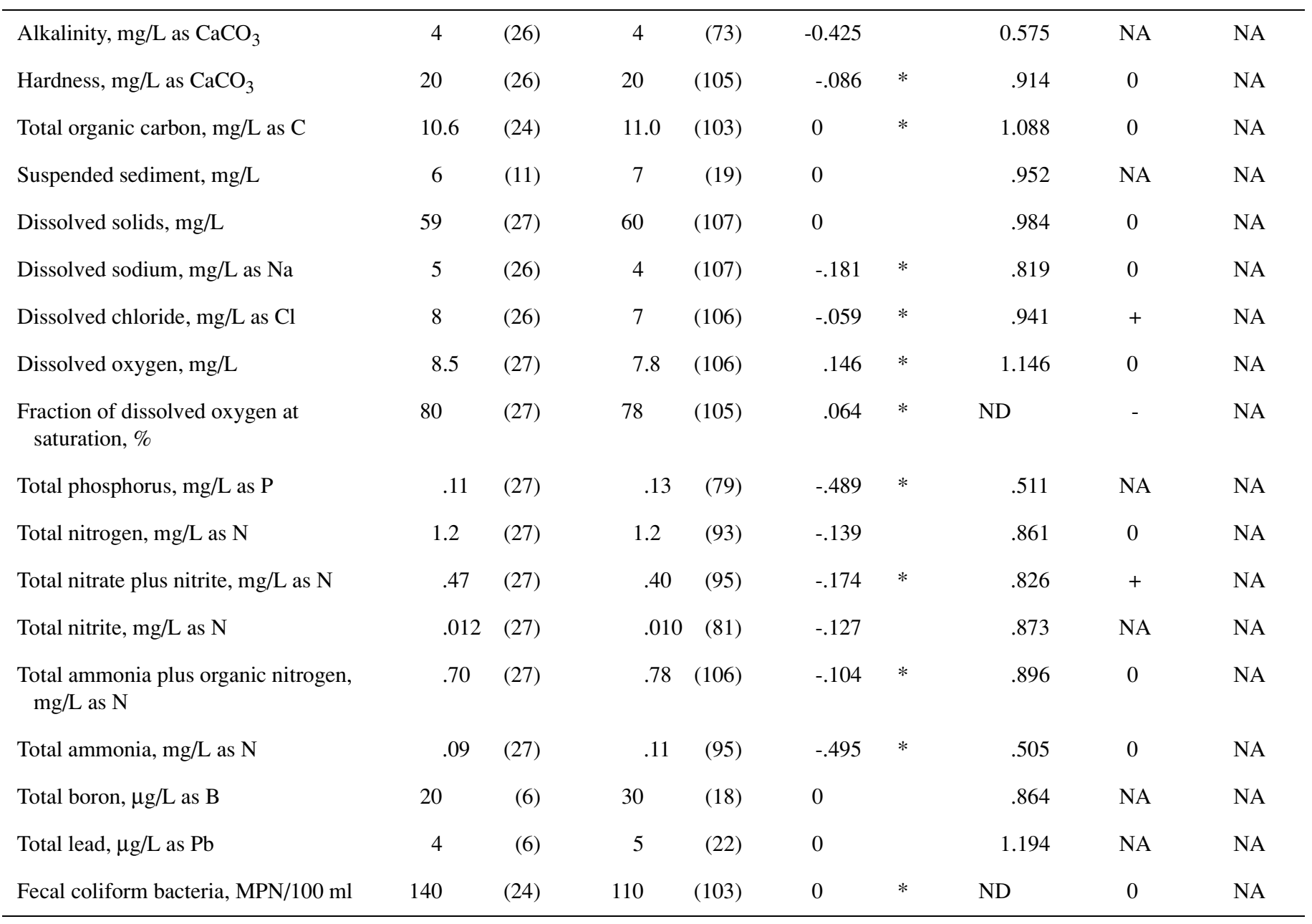

Table 20b. 1993 AMNET impairment status in the vicinity of water-quality station 01465850, South Branch Rancocas Creek at Vincentown, N.J.

[AMNET, Ambient Biomonitoring Network; WQ, water-quality. Upstream from WQ station is within 5 miles upstream from the WQ station; at WQ-station location is within 0.5 mile upstream or downstream from the WQ station; downstream from WQ station is within 5 miles downstream from the WQ station; ND, undetermined impairment status]

\begin{tabular}{lccc}
\hline & Upstream from WQ station & At WQ-station location & Downstream from WQ station \\
\hline AMNET station & AN0156 & None & AN0161 \\
Impairment status & Severely impaired & ND & Moderately impaired \\
\hline
\end{tabular}


Table 21a. Median concentrations, relations of concentration and load to streamflow, and directions of concentration trends for selected waterquality constituents at water-quality station 01466500, McDonalds Branch in Lebanon State Forest, N.J.

[Number in parenthesis is the number of available data values; WY, water years; $\mathrm{mg} / \mathrm{L}$, milligrams per liter; $\mathrm{CaCO}_{3}$, calcium carbonate; $\mathrm{C}$, carbon; Na, sodium; $\mathrm{Cl}$, chloride; \%, percent; $\mathrm{P}$, phosphorus; $\mathrm{N}$, nitrogen; $\mu \mathrm{g} / \mathrm{L}$, micrograms per liter; $\mathrm{B}$, boron; $\mathrm{Pb}$, lead; MPN/100 mL, most probable number per 100 milliliters. Regression slopes and trend directions are zero when the slope is not different from zero at the 0.05 significance level; * indicates seasonal dependency (the slope and (or) intercept of growing (April through October) and non-growing (November through March) season data were different at the 0.05 significance level); +, positive trend direction; -, negative trend direction; NA, insufficient data for analysis; ND, undetermined value]

\begin{tabular}{|c|c|c|c|c|c|c|c|c|c|}
\hline \multirow{3}{*}{$\begin{array}{c}\text { Constituent } \\
\text { Alkalinity, } \mathrm{mg} / \mathrm{L} \text { as } \mathrm{CaCO}_{3}\end{array}$} & \multicolumn{2}{|c|}{ 1989-93 WY } & \multicolumn{7}{|c|}{ 1976-93 WY } \\
\hline & \multicolumn{2}{|c|}{$\begin{array}{c}\text { Median } \\
\text { concentration }\end{array}$} & \multicolumn{2}{|c|}{$\begin{array}{l}\text { Median } \\
\text { concentration }\end{array}$} & \multicolumn{2}{|c|}{$\begin{array}{l}\text { Regression } \\
\text { slope of } \\
\text { concentration to } \\
\text { streamflow }\end{array}$} & \multirow{2}{*}{$\begin{array}{c}\begin{array}{c}\text { Regression } \\
\text { slope of } \\
\text { load to } \\
\text { streamflow }\end{array} \\
\text { ND }\end{array}$} & \multirow{2}{*}{$\begin{array}{c}\begin{array}{c}\text { Low- } \\
\text { flow } \\
\text { trend } \\
\text { direction }\end{array} \\
\text { NA }\end{array}$} & \multirow{2}{*}{$\begin{array}{c}\begin{array}{c}\text { High- } \\
\text { flow } \\
\text { trend } \\
\text { direction }\end{array} \\
\text { NA }\end{array}$} \\
\hline & $<1$ & $(0)$ & $<1$ & $(125)$ & ND & & & & \\
\hline Hardness, $\mathrm{mg} / \mathrm{L}$ as $\mathrm{CaCO}_{3}$ & 3 & $(59)$ & 3 & $(154)$ & .151 & $*$ & 1.150 & 0 & NA \\
\hline Total organic carbon, $\mathrm{mg} / \mathrm{L}$ as $\mathrm{C}$ & 3.7 & (2) & 4.8 & $(63)$ & .696 & & 1.696 & NA & NA \\
\hline Suspended sediment, $\mathrm{mg} / \mathrm{L}$ & 3 & $(58)$ & 2 & $(164)$ & 0 & $*$ & 1.131 & 0 & 0 \\
\hline Dissolved solids, mg/L & 22 & $(59)$ & 22 & $(148)$ & .345 & & 1.345 & 0 & 0 \\
\hline Dissolved sodium, $\mathrm{mg} / \mathrm{L}$ as $\mathrm{Na}$ & 2 & $(59)$ & 2 & $(156)$ & -.073 & $*$ & .927 & 0 & NA \\
\hline Dissolved chloride, $\mathrm{mg} / \mathrm{L}$ as $\mathrm{Cl}$ & 4 & $(58)$ & 4 & $(154)$ & 0 & & .970 & 0 & 0 \\
\hline Dissolved oxygen, $\mathrm{mg} / \mathrm{L}$ & 3.4 & $(58)$ & 3.6 & $(156)$ & .342 & $*$ & 1.342 & 0 & 0 \\
\hline $\begin{array}{l}\text { Fraction of dissolved oxygen at } \\
\text { saturation, } \%\end{array}$ & 31 & $(57)$ & 34 & $(152)$ & .291 & $*$ & ND & 0 & 0 \\
\hline Total phosphorus, $\mathrm{mg} / \mathrm{L}$ as $\mathrm{P}$ & .01 & $(60)$ & .01 & $(150)$ & 0 & & 1.100 & 0 & 0 \\
\hline Total nitrogen, $\mathrm{mg} / \mathrm{L}$ as $\mathrm{N}$ & .3 & $(60)$ & .3 & $(126)$ & .387 & & 1.387 & NA & NA \\
\hline Total nitrate plus nitrite, $\mathrm{mg} / \mathrm{L}$ as $\mathrm{N}$ & $<.06$ & $(60)$ & .02 & $(148)$ & 0 & $*$ & .859 & 0 & 0 \\
\hline Total nitrite, $\mathrm{mg} / \mathrm{L}$ as $\mathrm{N}$ & $<.01$ & $(60)$ & $<.01$ & (89) & ND & & ND & NA & NA \\
\hline $\begin{array}{l}\text { Total ammonia plus organic nitrogen, } \\
\mathrm{mg} / \mathrm{L} \text { as } \mathrm{N}\end{array}$ & .19 & $(60)$ & .20 & $(132)$ & .752 & & 1.752 & NA & NA \\
\hline Total ammonia, $\mathrm{mg} / \mathrm{L}$ as $\mathrm{N}$ & .02 & $(51)$ & .02 & $(103)$ & 0 & & .856 & NA & NA \\
\hline Total boron, $\mu \mathrm{g} / \mathrm{L}$ as $\mathrm{B}$ & ND & $(0)$ & ND & $(0)$ & ND & & ND & NA & NA \\
\hline Total lead, $\mu \mathrm{g} / \mathrm{L}$ as $\mathrm{Pb}$ & ND & $(0)$ & 4 & (11) & ND & & 1.194 & NA & NA \\
\hline Fecal coliform bacteria, MPN/100 ml & ND & $(0)$ & ND & $(0)$ & ND & & ND & NA & NA \\
\hline
\end{tabular}

Table 21b. 1993 AMNET impairment status in the vicinity of water-quality station 01466500, McDonalds Branch in Lebanon State Forest N.J.

[AMNET, Ambient Biomonitoring Network; WQ, water-quality. Upstream from WQ station is within 5 miles upstream from the WQ station; at WQ-station location is within 0.5 mile upstream or downstream from the WQ station; downstream from WQ station is within 5 miles downstream from the WQ station; ND, undetermined impairment status]

\begin{tabular}{lccc}
\hline & Upstream from WQ station & At WQ-station location & Downstream from WQ station \\
\hline AMNET station & None & AN0146 & None \\
Impairment status & ND & Moderately impaired & ND \\
\hline
\end{tabular}


Table 22a. Median concentrations, relations of concentration and load to streamflow, and directions of concentration trends for selected waterquality constituents at water-quality station 01467000, North Branch Rancocas Creek at Pemberton, N.J.

[Number in parenthesis is the number of available data values; WY, water years; $\mathrm{mg} / \mathrm{L}$, milligrams per liter; $\mathrm{CaCO}_{3}$, calcium carbonate; $\mathrm{C}$, carbon; Na, sodium; $\mathrm{Cl}$, chloride; \%, percent; $\mathrm{P}$, phosphorus; $\mathrm{N}$, nitrogen; $\mu \mathrm{g} / \mathrm{L}$, micrograms per liter; $\mathrm{B}$, boron; Pb, lead; MPN/100 mL, most probable number per 100 milliliters. Regression slopes and trend directions are zero when the slope is not different from zero at the 0.05 significance level; * indicates seasonal dependency (the slope and (or) intercept of growing (April through October) and non-growing (November through March) season data were different at the 0.05 significance level); +, positive trend direction; -, negative trend direction; NA, insufficient data for analysis; ND, undetermined value]

\begin{tabular}{|c|c|c|c|c|c|c|}
\hline \multirow[b]{2}{*}{ Constituent } & \multirow{2}{*}{$\begin{array}{c}\text { 1989-93 WY } \\
\text { Median } \\
\text { concentration }\end{array}$} & \multicolumn{5}{|c|}{ 1976-93 WY } \\
\hline & & $\begin{array}{c}\text { Median } \\
\text { concentration }\end{array}$ & $\begin{array}{c}\text { Regression } \\
\text { slope of } \\
\text { concentration to } \\
\text { streamflow }\end{array}$ & $\begin{array}{l}\text { Regression } \\
\text { slope of } \\
\text { load to } \\
\text { streamflow }\end{array}$ & $\begin{array}{l}\text { Low- } \\
\text { flow } \\
\text { trend } \\
\text { direction }\end{array}$ & $\begin{array}{l}\text { High- } \\
\text { flow } \\
\text { trend } \\
\text { direction }\end{array}$ \\
\hline
\end{tabular}

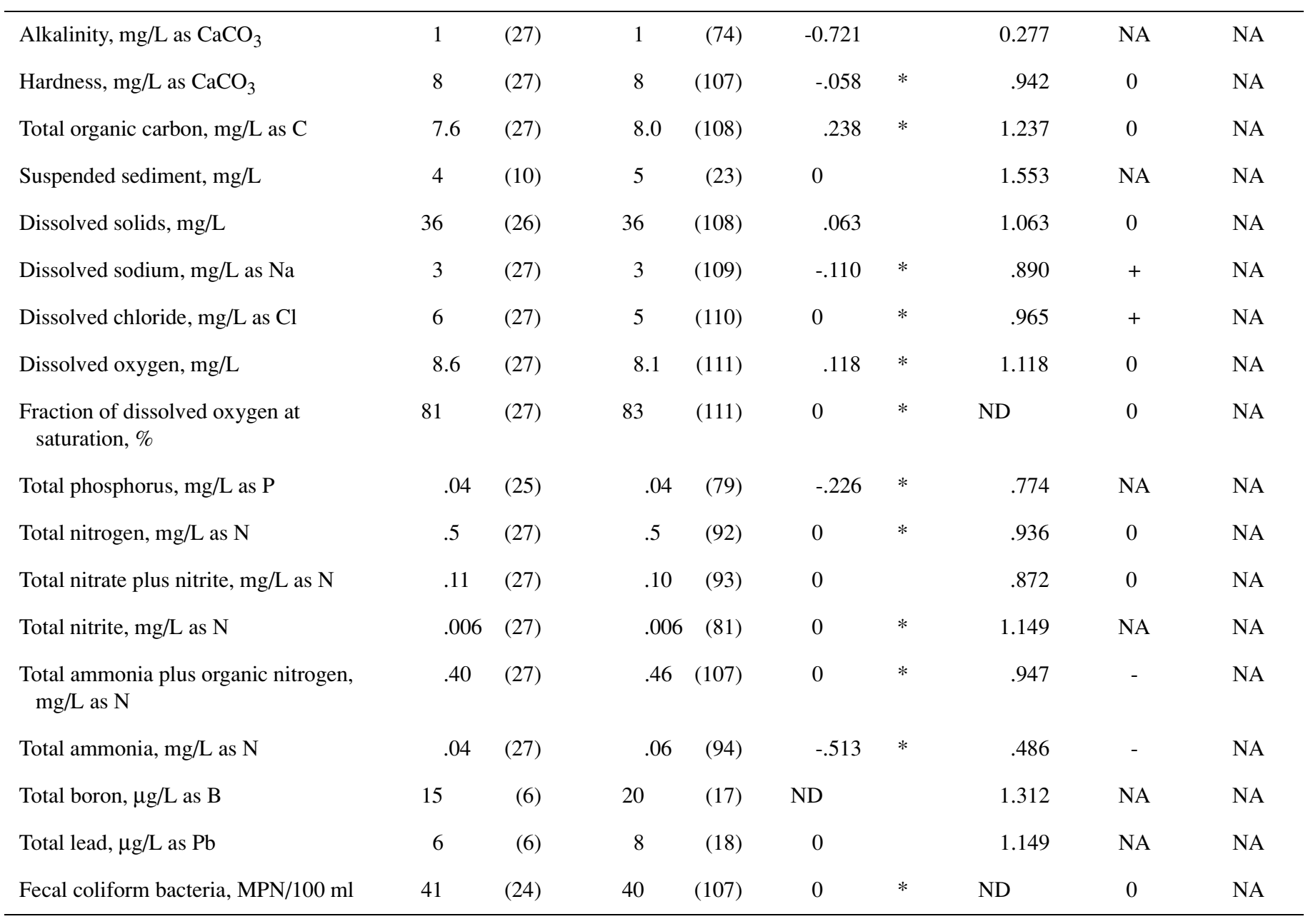

Table 22b. 1993 AMNET impairment status in the vicinity of water-quality station 01467000, North Branch Rancocas Creek at Pemberton, N.J.

[AMNET, Ambient Biomonitoring Network; WQ, water-quality. Upstream from WQ station is within 5 miles upstream from the WQ station; at WQ-station location is within 0.5 mile upstream or downstream from the WQ station; downstream from WQ station is within 5 miles downstream from the WQ station; ND, undetermined impairment status]

\begin{tabular}{lccr}
\hline & Upstream from WQ station & At WQ-station location & Downstream from WQ station \\
\hline AMNET station & None & AN0149 & AN0151 \\
Impairment status & ND & Non-impaired & Moderately impaired \\
\hline
\end{tabular}




\section{Pennsauken Creek}

The Pennsauken Creek Basin has two water-quality stations — station 01467069 on the North Branch of Pennsauken Creek near Moorestown and 01467081 on the South Branch of Pennsauken Creek at Cherry Hill. The 5-year medians are smaller than the period-of-record medians for TN, NO2, TAON, and NH4 at station 01467069; 5-year and period-of-record medians are similar for all other constituents (table 23a). The 5-year medians are smaller than the period-of-record medians for TP, TAON, and NH4 and larger for NO2 at station 01467081 (table 24a). At station 01467081, the period-of-record medians for HARD, DS, NA, CL, NO2, B, and BACT are the largest for these constituents at all stations in the study area. The regression slopes of concentration to streamflow for HARD, TOC, DS, NA, CL, DO, TP, NO32, NO2, NH4, and BACT show seasonal dependency at station 01467069. The concentration slopes for HARD, DS, NA, CL, DO, FDO, NO2, and BACT show seasonal dependency at station 01467081.

The regression slope of load to streamflow is in the high range only for ALK at station 01467069, indicating greater contribution of ALK from storm runoff relative to that at other sites in the study area. The load slope for ALK at station 01467069 is the largest for this constituent in the study area. Load slopes are in the low range for TOC, SS, and TAON at station 01467069 and for HARD, DS, NA, TN, NO2, TAON, NH4, and B at station 01467081, indicating smaller contributions of these constituents from storm runoff relative to that at other sites in the study area. The load slopes for NO2 and TAON at station 01467081 are the smallest for these constituents in the study area.

During low flows, trends are positive for HARD and CL at station 01467081, indicating an increase in the contributions of these constituents from point sources and ground water over time. Trends are negative for NA, TN, NO32, TAON, NH4, and PB at station 01467069 and for $\mathrm{TN}$ at station 01467081, indicating a decrease in the contributions of these constituents from storm runoff over time. Trends are insignificant during low flows for TOC, DS, FDO, and BACT at both stations, for HARD and CL at station 01467069, and for NA, DO, NO32, TAON, and NH4 at station 01467081 . Insufficient data are available at both stations to determine trends for all other constituents during low flows and for all constituents during high flows.

The AMNET impairment status is moderately impaired upstream and downstream from station 01467069 (table 23b). The AMNET impairment status is severely impaired upstream and downstream from station 01467081 (table 24b).

\section{Cooper River}

For the one station on the Cooper River, station 01467150 at Haddonfield, the 5-year medians for TP, TN, NO32, NO2, TAON, and NH4 are smaller than the period-of-record medians (table 25a). The period-of-record medians for SS, TP, TN, TAON, NH4, and PB are the largest for these constituents at all stations in the study area. The regression slopes of concentration to streamflow for HARD, DO, FDO, TP, NO2, and BACT show seasonal dependency. The regression slopes of load to streamflow are in the high range for ALK, NA, and NO2, indicating larger contributions of these constituents from storm runoff relative to that at other sites in the study area. Insufficient data are available to determine trends during low flows for all 
Table 23a. Median concentrations, relations of concentration and load to streamflow, and directions of concentration trends for selected waterquality constituents at water-quality station 01467069, North Branch Pennsauken Creek near Moorestown, N.J.

[Number in parenthesis is the number of available data values; WY, water years; $\mathrm{mg} / \mathrm{L}$, milligrams per liter; $\mathrm{CaCO}_{3}$, calcium carbonate; $\mathrm{C}$, carbon; Na, sodium; $\mathrm{Cl}$, chloride; \%, percent; $\mathrm{P}$, phosphorus; $\mathrm{N}$, nitrogen; $\mu \mathrm{g} / \mathrm{L}$, micrograms per liter; $\mathrm{B}$, boron; Pb, lead; MPN/100 mL, most probable number per 100 milliliters. Regression slopes and trend directions are zero when the slope is not different from zero at the 0.05 significance level; * indicates seasonal dependency (the slope and (or) intercept of growing (April through October) and non-growing (November through March) season data were different at the 0.05 significance level); +, positive trend direction; -, negative trend direction; NA, insufficient data for analysis; ND, undetermined value]

\begin{tabular}{|c|c|c|c|c|c|c|}
\hline \multirow[b]{2}{*}{ Constituent } & \multirow{2}{*}{$\begin{array}{c}\text { 1989-93 WY } \\
\text { Median } \\
\text { concentration }\end{array}$} & \multicolumn{5}{|c|}{ 1976-93 WY } \\
\hline & & $\begin{array}{c}\text { Median } \\
\text { concentration }\end{array}$ & $\begin{array}{c}\text { Regression } \\
\text { slope of } \\
\text { concentration to } \\
\text { streamflow }\end{array}$ & $\begin{array}{l}\text { Regression } \\
\text { slope of } \\
\text { load to } \\
\text { streamflow }\end{array}$ & $\begin{array}{l}\text { Low- } \\
\text { flow } \\
\text { trend } \\
\text { direction }\end{array}$ & $\begin{array}{l}\text { High- } \\
\text { flow } \\
\text { trend } \\
\text { direction }\end{array}$ \\
\hline
\end{tabular}

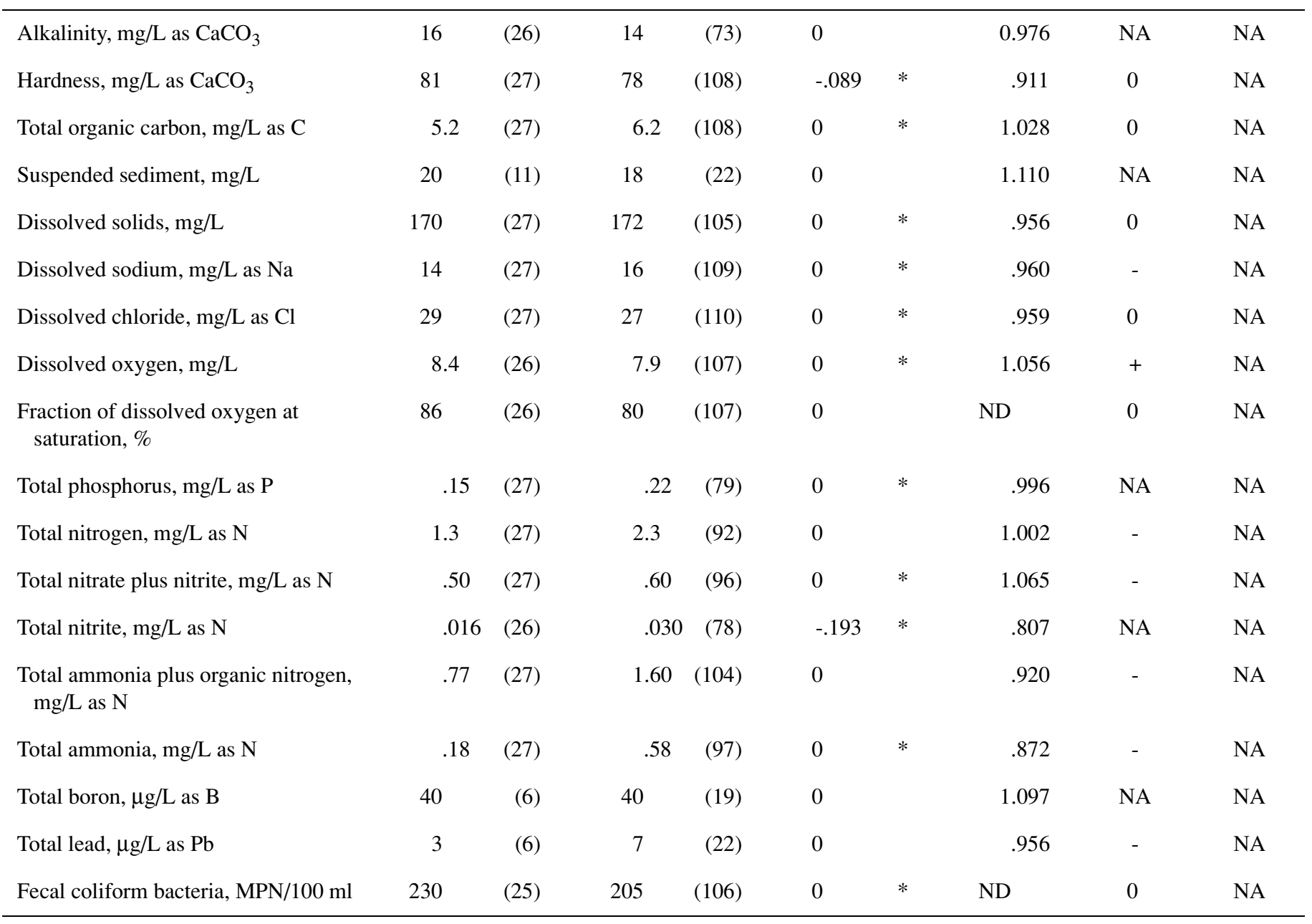

Table 23b. 1993 AMNET impairment status in the vicinity of water-quality station 01467069, North Branch Pennsauken Creek near Moorestown, N.J.

[AMNET, Ambient Biomonitoring Network; WQ, water-quality. Upstream from WQ station is within 5 miles upstream from the WQ station; at WQ-station location is within 0.5 mile upstream or downstream from the WQ station; downstream from WQ station is within 5 miles downstream from the WQ station; ND, undetermined impairment status]

\begin{tabular}{lccc}
\hline & Upstream from WQ station & At WQ-station location & Downstream from WQ station \\
\hline AMNET station & AN0179 & None & AN0180 \\
Impairment status & Moderately impaired & ND & Moderately impaired \\
\hline
\end{tabular}


Table 24a. Median concentrations, relations of concentration and load to streamflow, and directions of concentration trends for selected waterquality constituents at water-quality station 01467081, South Branch Pennsauken Creek at Cherry Hill, N.J.

[Number in parenthesis is the number of available data values; WY, water years; $\mathrm{mg} / \mathrm{L}$, milligrams per liter; $\mathrm{CaCO}_{3}$, calcium carbonate; $\mathrm{C}$, carbon; Na, sodium; $\mathrm{Cl}$, chloride; \%, percent; $\mathrm{P}$, phosphorus; $\mathrm{N}$, nitrogen; $\mu \mathrm{g} / \mathrm{L}$, micrograms per liter; $\mathrm{B}$, boron; $\mathrm{Pb}$, lead; MPN/100 mL, most probable number per 100 milliliters. Regression slopes and trend directions are zero when the slope is not different from zero at the 0.05 significance level; * indicates seasonal dependency (the slope and (or) intercept of growing (April through October) and non-growing (November through March) season data were different at the 0.05 significance level); +, positive trend direction; -, negative trend direction; NA, insufficient data for analysis; ND, undetermined value]

\begin{tabular}{|c|c|c|c|c|c|c|c|c|c|}
\hline \multirow{3}{*}{$\begin{array}{c}\text { Constituent } \\
\text { Alkalinity, } \mathrm{mg} / \mathrm{L} \text { as } \mathrm{CaCO}_{3}\end{array}$} & \multirow{2}{*}{\multicolumn{2}{|c|}{$\begin{array}{c}\text { 1989-93 WY } \\
\text { Median } \\
\text { concentration }\end{array}$}} & \multicolumn{7}{|c|}{ 1976-93 WY } \\
\hline & & & \multicolumn{2}{|c|}{$\begin{array}{c}\text { Median } \\
\text { concentration }\end{array}$} & \multicolumn{2}{|c|}{$\begin{array}{c}\text { Regression } \\
\text { slope of } \\
\text { concentration to } \\
\text { streamflow }\end{array}$} & \multirow{2}{*}{$\begin{array}{c}\begin{array}{c}\text { Regression } \\
\text { slope of } \\
\text { load to } \\
\text { streamflow }\end{array} \\
0.608\end{array}$} & \multirow{2}{*}{$\begin{array}{c}\begin{array}{c}\text { Low- } \\
\text { flow } \\
\text { trend } \\
\text { direction }\end{array} \\
\text { NA }\end{array}$} & \multirow{2}{*}{$\begin{array}{c}\text { High- } \\
\text { flow } \\
\text { trend } \\
\text { direction } \\
\text { NA }\end{array}$} \\
\hline & 40 & $(27)$ & 39 & (73) & -0.392 & & & & \\
\hline Hardness, $\mathrm{mg} / \mathrm{L}$ as $\mathrm{CaCO}_{3}$ & 86 & $(27)$ & 85 & $(110)$ & -.164 & $*$ & .836 & + & NA \\
\hline Total organic carbon, $\mathrm{mg} / \mathrm{L}$ as $\mathrm{C}$ & 6.3 & $(25)$ & 6.8 & $(105)$ & .145 & & 1.145 & 0 & NA \\
\hline Suspended sediment, $\mathrm{mg} / \mathrm{L}$ & 6 & (11) & 14 & $(26)$ & .802 & & 1.797 & NA & NA \\
\hline Dissolved solids, $\mathrm{mg} / \mathrm{L}$ & 202 & $(27)$ & 205 & $(108)$ & -.168 & $*$ & .832 & 0 & NA \\
\hline Dissolved sodium, $\mathrm{mg} / \mathrm{L}$ as $\mathrm{Na}$ & 24 & $(27)$ & 24 & $(110)$ & -.336 & $*$ & .664 & 0 & NA \\
\hline Dissolved chloride, $\mathrm{mg} / \mathrm{L}$ as $\mathrm{Cl}$ & 30 & $(27)$ & 30 & $(110)$ & -.168 & $*$ & .832 & + & NA \\
\hline Dissolved oxygen, $\mathrm{mg} / \mathrm{L}$ & 6.3 & $(26)$ & 6.3 & $(108)$ & .214 & $*$ & 1.213 & 0 & NA \\
\hline $\begin{array}{l}\text { Fraction of dissolved oxygen at } \\
\text { saturation, } \%\end{array}$ & 68 & (26) & 67 & $(107)$ & .128 & $*$ & ND & 0 & NA \\
\hline Total phosphorus, $\mathrm{mg} / \mathrm{L}$ as $\mathrm{P}$ & .44 & (24) & .65 & (76) & 0 & & .835 & NA & NA \\
\hline Total nitrogen, $\mathrm{mg} / \mathrm{L}$ as $\mathrm{N}$ & 4.5 & $(27)$ & 4.8 & (95) & -.312 & & .687 & - & NA \\
\hline Total nitrate plus nitrite, $\mathrm{mg} / \mathrm{L}$ as $\mathrm{N}$ & 1.55 & $(27)$ & 1.46 & $(100)$ & -.242 & & .758 & 0 & NA \\
\hline Total nitrite, $\mathrm{mg} / \mathrm{L}$ as $\mathrm{N}$ & .182 & (26) & .155 & (79) & -.766 & $*$ & .234 & NA & NA \\
\hline $\begin{array}{l}\text { Total ammonia plus organic nitrogen, } \\
\mathrm{mg} / \mathrm{L} \text { as } \mathrm{N}\end{array}$ & 1.99 & $(27)$ & 3.30 & $(103)$ & -.309 & & .691 & 0 & NA \\
\hline Total ammonia, $\mathrm{mg} / \mathrm{L}$ as $\mathrm{N}$ & 1.43 & $(27)$ & 2.20 & $(97)$ & -.442 & & .558 & 0 & NA \\
\hline Total boron, $\mu \mathrm{g} / \mathrm{L}$ as $\mathrm{B}$ & 120 & (7) & 140 & (19) & -.644 & & .355 & NA & NA \\
\hline Total lead, $\mu \mathrm{g} / \mathrm{L}$ as $\mathrm{Pb}$ & 2 & (7) & 5 & $(22)$ & .906 & & 1.905 & NA & NA \\
\hline Fecal coliform bacteria, MPN/100 ml & 3300 & $(25)$ & 3400 & $(106)$ & 0 & $*$ & ND & 0 & NA \\
\hline
\end{tabular}

Table 24b. 1993 AMNET impairment status in the vicinity of water-quality station 01467081, South Branch Pennsauken Creek at Cherry Hill, N.J.

[AMNET, Ambient Biomonitoring Network; WQ, water-quality. Upstream from WQ station is within 5 miles upstream from the WQ station; at WQ-station location is within 0.5 mile upstream or downstream from the WQ station; downstream from WQ station is within 5 miles downstream from the WQ station; ND, undetermined impairment status]

\begin{tabular}{lccc}
\hline & Upstream from WQ station & At WQ-station location & Downstream from WQ station \\
\hline AMNET station & AN0183 & None & AN0184 \\
Impairment status & Severely impaired & ND & Severely impaired \\
\hline
\end{tabular}


Table 25a. Median concentrations, relations of concentration and load to streamflow, and directions of concentration trends for selected waterquality constituents at water-quality station 01467150, Cooper River at Haddonfield, N.J.

[Number in parenthesis is the number of available data values; WY, water years; $\mathrm{mg} / \mathrm{L}$, milligrams per liter; $\mathrm{CaCO}_{3}$, calcium carbonate; $\mathrm{C}$, carbon; Na, sodium; $\mathrm{Cl}$, chloride; \%, percent; $\mathrm{P}$, phosphorus; $\mathrm{N}$, nitrogen; $\mu \mathrm{g} / \mathrm{L}$, micrograms per liter; $\mathrm{B}$, boron; Pb, lead; MPN/100 mL, most probable number per 100 milliliters. Regression slopes and trend directions are zero when the slope is not different from zero at the 0.05 significance level; * indicates seasonal dependency (the slope and (or) intercept of growing (April through October) and non-growing (November through March) season data were different at the 0.05 significance level); +, positive trend direction; -, negative trend direction; NA, insufficient data for analysis; ND, undetermined value]

\begin{tabular}{|c|c|c|c|c|c|c|}
\hline \multirow[b]{2}{*}{ Constituent } & \multirow{2}{*}{$\begin{array}{c}\text { 1989-93 WY } \\
\text { Median } \\
\text { concentration }\end{array}$} & \multicolumn{5}{|c|}{ 1976-93 WY } \\
\hline & & $\begin{array}{c}\text { Median } \\
\text { concentration }\end{array}$ & $\begin{array}{l}\text { Regression } \\
\text { slope of } \\
\text { concentration to } \\
\text { streamflow }\end{array}$ & $\begin{array}{l}\text { Regression } \\
\text { slope of } \\
\text { load to } \\
\text { streamflow }\end{array}$ & $\begin{array}{l}\text { Low- } \\
\text { flow } \\
\text { trend } \\
\text { direction }\end{array}$ & $\begin{array}{l}\text { High- } \\
\text { flow } \\
\text { trend } \\
\text { direction }\end{array}$ \\
\hline
\end{tabular}

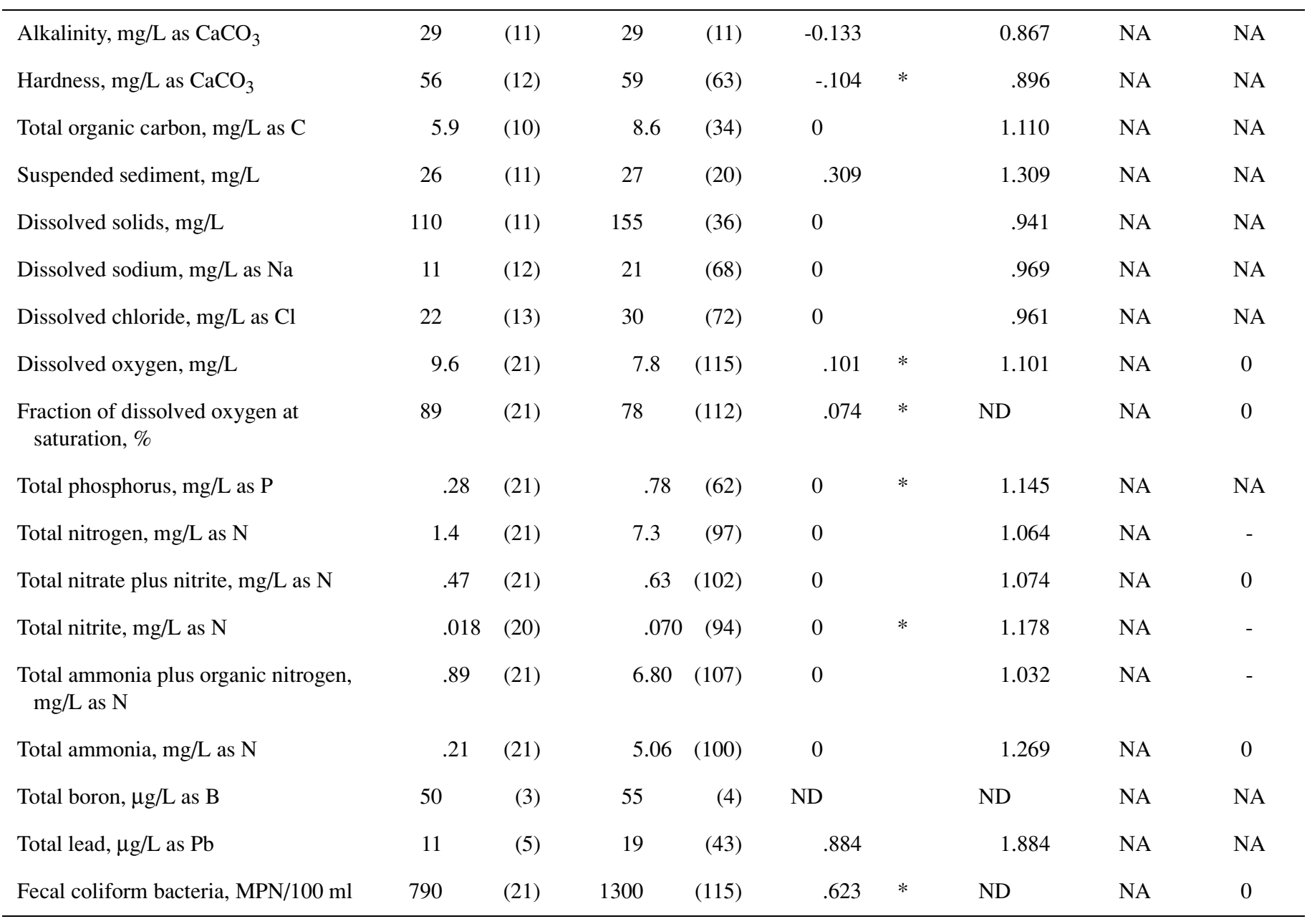

Table 25b. 1993 AMNET impairment status in the vicinity of water-quality station 01467150, Cooper River at Haddonfield, N.J.

[AMNET, Ambient Biomonitoring Network; WQ, water-quality. Upstream from WQ station is within 5 miles upstream from the WQ station; at WQ-station location is within 0.5 mile upstream or downstream from the WQ station; downstream from WQ station is within 5 miles downstream from the WQ station; ND, undetermined impairment status]

\begin{tabular}{lccc}
\hline & Upstream from WQ station & At WQ-station location & Downstream from WQ station \\
\hline AMNET station & AN0190 & AN0191 & None \\
Impairment status & Severely impaired & Severely impaired & ND \\
\hline
\end{tabular}


constituents. During high flows, the trend is negative for TN, NO2, and TAON, indicating a decrease in the contributions of these constituents from storm runoff over time. Also during high flow, trends are insignificant for DO, FDO, NO32, NH4, and BACT. Insufficient data are available to determine trends during high flows for all other constituents. The AMNET impairment status is severely impaired at and upstream from station 01467150 (table 25b).

\section{$\underline{\text { South Branch Big Timber Creek }}$}

For the one station on the South Branch Big Timber Creek, station 01467329 at Blackwood Terrace, the 5-year and period-of-record medians are similar (table 26a). The regression slopes of concentration to streamflow for HARD, TOC, DS, NA, CL, DO, FDO, TP, TN, NO32, NO2, NH4, and BACT show seasonal dependency. The regression slope of load to streamflow is in the high range for ALK, indicating a larger contribution from storm runoff relative to that at other sites in the study area. The load slope is in the low range for DO. Insufficient data are available for all constituents to determine trends during low and high flows. The AMNET impairment status is moderately impaired downstream from station 01467329 (table 26b).

\section{$\underline{\text { Raccoon Creek }}$}

For the one station on the Raccoon Creek, station 01477120 near Swedesboro, the 5-year and period-of-record medians are similar (table 27a). The period-of-record medians for TOC and $\mathrm{PB}$ are the smallest at station 01477120 for these constituents at all stations in the study area. The regression slopes of concentration to streamflow for ALK, HARD, TOC, DS, DO, TP, NO32, NO2, TAON, and BACT show seasonal dependency. The regression slope of load to streamflow is in the high range for $\mathrm{TN}$, indicating a larger contribution from storm runoff relative to that at other sites in the study area. The load slopes are in the low range for HARD and DS, indicating smaller contributions of these constituents from storm runoff relative to that at other sites in the study area. During low flows, the trend is positive for CL, indicating an increase in the contributions of these constituents from point sources and ground water over time; trends are negative for TOC and FDO, indicating a decrease in the contributions of these constituents from point sources and ground water over time. Trends are insignificant for HARD, NA, DO, TP, TN, NO32, TAON, NH4, and BACT during low flows. Insufficient data are available to determine trends during low flows for all other constituents. During high flows, trends are positive for DS, $\mathrm{NA}$, and CL, indicating an increase in the contributions of these constituents from storm runoff over time. Trends are insignificant for HARD, TOC, DO, FDO, TN, NO32, TAON, and BACT during high flows. Insufficient data are available for all other constituents to determine trends during high flows. The AMNET impairment status is moderately impaired at and upstream and downstream from station 01477120 (table 27b).

\section{Oldmans Creek}

For the one station on the Oldmans Creek, station 01477510 at Porches Mill, the 5-year and period-of-record medians are similar for all constituents (table 28a). The regression slopes of concentration to streamflow for ALK, TOC, NA, DO, TP, TN, NO32, NO2, TAON, and BACT 
Table 26a. Median concentrations, relations of concentration and load to streamflow, and directions of concentration trends for selected waterquality constituents at water-quality station 01467329, South Branch Big Timber Creek at Blackwood Terrace, N.J.

[Number in parenthesis is the number of available data values; WY, water years; $\mathrm{mg} / \mathrm{L}$, milligrams per liter; $\mathrm{CaCO}_{3}$, calcium carbonate; $\mathrm{C}$, carbon; Na, sodium; $\mathrm{Cl}$, chloride; \%, percent; $\mathrm{P}$, phosphorus; $\mathrm{N}$, nitrogen; $\mu \mathrm{g} / \mathrm{L}$, micrograms per liter; $\mathrm{B}$, boron; Pb, lead; MPN/100 mL, most probable number per 100 milliliters. Regression slopes and trend directions are zero when the slope is not different from zero at the 0.05 significance level; * indicates seasonal dependency (the slope and (or) intercept of growing (April through October) and non-growing (November through March) season data were different at the 0.05 significance level); +, positive trend direction; -, negative trend direction; NA, insufficient data for analysis; ND, undetermined value]

\begin{tabular}{|c|c|c|c|c|c|c|c|c|c|}
\hline \multirow{3}{*}{$\begin{array}{c}\text { Constituent } \\
\text { Alkalinity, } \mathrm{mg} / \mathrm{L} \text { as } \mathrm{CaCO}_{3}\end{array}$} & \multirow{2}{*}{\multicolumn{2}{|c|}{$\begin{array}{c}\text { 1989-93 WY } \\
\text { Median } \\
\text { concentration }\end{array}$}} & \multicolumn{7}{|c|}{ 1976-93 WY } \\
\hline & & & \multicolumn{2}{|c|}{$\begin{array}{c}\text { Median } \\
\text { concentration }\end{array}$} & \multicolumn{2}{|c|}{$\begin{array}{l}\text { Regression } \\
\text { slope of } \\
\text { concentration to } \\
\text { streamflow }\end{array}$} & \multirow{2}{*}{$\begin{array}{c}\begin{array}{c}\text { Regression } \\
\text { slope of } \\
\text { load to } \\
\text { streamflow }\end{array} \\
0.906\end{array}$} & \multirow{2}{*}{$\begin{array}{c}\begin{array}{c}\text { Low- } \\
\text { flow } \\
\text { trend } \\
\text { direction }\end{array} \\
\text { NA }\end{array}$} & \multirow{2}{*}{$\begin{array}{c}\begin{array}{c}\text { High- } \\
\text { flow } \\
\text { trend } \\
\text { direction }\end{array} \\
\text { NA }\end{array}$} \\
\hline & 25 & $(27)$ & 24 & (72) & -0.094 & & & & \\
\hline Hardness, $\mathrm{mg} / \mathrm{L}$ as $\mathrm{CaCO}_{3}$ & 41 & $(27)$ & 39 & $(103)$ & -.044 & $*$ & .955 & NA & NA \\
\hline Total organic carbon, $\mathrm{mg} / \mathrm{L}$ as $\mathrm{C}$ & 4.7 & $(27)$ & 4.7 & $(103)$ & .163 & $*$ & 1.163 & NA & NA \\
\hline Suspended sediment, mg/L & 16 & $(11)$ & 18 & $(18)$ & .630 & & 1.628 & NA & NA \\
\hline Dissolved solids, mg/L & 89 & $(26)$ & 83 & $(101)$ & 0 & $*$ & .980 & NA & NA \\
\hline Dissolved sodium, $\mathrm{mg} / \mathrm{L}$ as $\mathrm{Na}$ & 11 & $(27)$ & 8 & $(105)$ & -.163 & $*$ & .837 & NA & NA \\
\hline Dissolved chloride, $\mathrm{mg} / \mathrm{L}$ as $\mathrm{Cl}$ & 17 & $(27)$ & 13 & $(103)$ & -.155 & $*$ & .845 & NA & NA \\
\hline Dissolved oxygen, $\mathrm{mg} / \mathrm{L}$ & 10.0 & (26) & 8.2 & $(103)$ & 0 & $*$ & 1.018 & NA & NA \\
\hline $\begin{array}{l}\text { Fraction of dissolved oxygen at } \\
\text { saturation, } \%\end{array}$ & 94 & $(26)$ & 85 & $(102)$ & 0 & * & ND & NA & NA \\
\hline Total phosphorus, $\mathrm{mg} / \mathrm{L}$ as $\mathrm{P}$ & .10 & (27) & .13 & (77) & .274 & * & 1.274 & NA & NA \\
\hline Total nitrogen, $\mathrm{mg} / \mathrm{L}$ as $\mathrm{N}$ & 1.9 & $(27)$ & 1.9 & $(92)$ & 0 & $*$ & 1.066 & NA & NA \\
\hline Total nitrate plus nitrite, $\mathrm{mg} / \mathrm{L}$ as $\mathrm{N}$ & 1.13 & $(27)$ & 1.12 & $(95)$ & 0 & * & .905 & NA & NA \\
\hline Total nitrite, $\mathrm{mg} / \mathrm{L}$ as $\mathrm{N}$ & .034 & $(26)$ & .031 & (77) & 0 & $*$ & 1.037 & NA & NA \\
\hline $\begin{array}{l}\text { Total ammonia plus organic nitrogen, } \\
\mathrm{mg} / \mathrm{L} \text { as } \mathrm{N}\end{array}$ & .73 & $(27)$ & .80 & $(101)$ & .169 & & 1.169 & NA & NA \\
\hline Total ammonia, $\mathrm{mg} / \mathrm{L}$ as $\mathrm{N}$ & .25 & $(27)$ & .22 & (93) & 0 & * & 1.138 & NA & NA \\
\hline Total boron, $\mu \mathrm{g} / \mathrm{L}$ as $\mathrm{B}$ & 90 & (6) & 50 & $(18)$ & 0 & & .788 & NA & NA \\
\hline Total lead, $\mu \mathrm{g} / \mathrm{L}$ as $\mathrm{Pb}$ & 4 & (6) & 6 & $(18)$ & 0 & & 1.408 & NA & NA \\
\hline Fecal coliform bacteria, MPN/100 ml & 490 & $(25)$ & 330 & $(100)$ & 1.185 & $*$ & ND & NA & NA \\
\hline
\end{tabular}

Table 26b. 1993 AMNET impairment status in the vicinity of water-quality station 01467329, South Branch Big Timber Creek at Blackwood Terrace, N.J.

[AMNET, Ambient Biomonitoring Network; WQ, water-quality. Upstream from WQ station is within 5 miles upstream from the WQ station; at WQ-station location is within 0.5 mile upstream or downstream from the WQ station; downstream from WQ station is within 5 miles downstream from the WQ station; ND, undetermined impairment status]

\begin{tabular}{lccc}
\hline & Upstream from WQ station & At WQ-station location & Downstream from WQ station \\
\hline AMNET station & None & None & AN0659 \\
Impairment status & ND & ND & Moderately impaired \\
\hline
\end{tabular}


Table 27a. Median concentrations, relations of concentration and load to streamflow, and directions of concentration trends for selected waterquality constituents at water-quality station 01477120, Raccoon Creek near Swedesboro, N.J.

[Number in parenthesis is the number of available data values; WY, water years; $\mathrm{mg} / \mathrm{L}$, milligrams per liter; $\mathrm{CaCO}_{3}$, calcium carbonate; $\mathrm{C}$, carbon; Na, sodium; $\mathrm{Cl}$, chloride; \%, percent; $\mathrm{P}$, phosphorus; $\mathrm{N}$, nitrogen; $\mu \mathrm{g} / \mathrm{L}$, micrograms per liter; $\mathrm{B}$, boron; $\mathrm{Pb}$, lead; MPN/100 mL, most probable number per 100 milliliters. Regression slopes and trend directions are zero when the slope is not different from zero at the 0.05 significance level; * indicates seasonal dependency (the slope and (or) intercept of growing (April through October) and non-growing (November through March) season data were different at the 0.05 significance level); +, positive trend direction; -, negative trend direction; NA, insufficient data for analysis; ND, undetermined value]

\begin{tabular}{|c|c|c|c|c|c|c|c|c|c|}
\hline \multirow{3}{*}{$\begin{array}{c}\text { Constituent } \\
\text { Alkalinity, } \mathrm{mg} / \mathrm{L} \text { as } \mathrm{CaCO}_{3}\end{array}$} & \multicolumn{2}{|c|}{ 1989-93 WY } & \multicolumn{7}{|c|}{ 1976-93 WY } \\
\hline & \multicolumn{2}{|c|}{$\begin{array}{l}\text { Median } \\
\text { concentration }\end{array}$} & \multicolumn{2}{|c|}{$\begin{array}{l}\text { Median } \\
\text { concentration }\end{array}$} & \multicolumn{2}{|c|}{$\begin{array}{l}\text { Regression } \\
\text { slope of } \\
\text { concentration to } \\
\text { streamflow }\end{array}$} & \multirow{2}{*}{$\begin{array}{c}\begin{array}{c}\text { Regression } \\
\text { slope of } \\
\text { load to } \\
\text { streamflow }\end{array} \\
0.500\end{array}$} & \multirow{2}{*}{$\begin{array}{c}\begin{array}{c}\text { Low- } \\
\text { flow } \\
\text { trend } \\
\text { direction }\end{array} \\
\text { NA }\end{array}$} & \multirow{2}{*}{$\begin{array}{c}\begin{array}{c}\text { High- } \\
\text { flow } \\
\text { trend } \\
\text { direction }\end{array} \\
\text { NA }\end{array}$} \\
\hline & 25 & $(27)$ & 28 & (74) & -0.500 & $*$ & & & \\
\hline Hardness, $\mathrm{mg} / \mathrm{L}$ as $\mathrm{CaCO}_{3}$ & 63 & $(27)$ & 63 & $(111)$ & -.167 & $*$ & .833 & 0 & 0 \\
\hline Total organic carbon, $\mathrm{mg} / \mathrm{L}$ as $\mathrm{C}$ & 3.3 & (27) & 3.6 & $(107)$ & .163 & * & 1.163 & - & 0 \\
\hline Suspended sediment, $\mathrm{mg} / \mathrm{L}$ & 12 & (9) & 13 & (17) & .892 & & 1.890 & NA & NA \\
\hline Dissolved solids, $\mathrm{mg} / \mathrm{L}$ & 122 & $(25)$ & 117 & $(105)$ & -.122 & * & .878 & NA & + \\
\hline Dissolved sodium, $\mathrm{mg} / \mathrm{L}$ as $\mathrm{Na}$ & 8 & (27) & 6 & $(111)$ & -.122 & & .878 & 0 & + \\
\hline Dissolved chloride, $\mathrm{mg} / \mathrm{L}$ as $\mathrm{Cl}$ & 16 & $(27)$ & 13 & $(110)$ & -.073 & & .927 & + & + \\
\hline Dissolved oxygen, $\mathrm{mg} / \mathrm{L}$ & 9.3 & $(27)$ & 9.4 & $(110)$ & .102 & * & 1.102 & 0 & 0 \\
\hline $\begin{array}{l}\text { Fraction of dissolved oxygen at } \\
\text { saturation, } \%\end{array}$ & 89 & (26) & 93 & $(101)$ & 0 & & ND & - & 0 \\
\hline Total phosphorus, $\mathrm{mg} / \mathrm{L}$ as $\mathrm{P}$ & .11 & $(25)$ & .11 & $(100)$ & 0 & $*$ & 1.031 & 0 & NA \\
\hline Total nitrogen, $\mathrm{mg} / \mathrm{L}$ as $\mathrm{N}$ & 2.7 & $(27)$ & 2.2 & (97) & .260 & & 1.260 & 0 & 0 \\
\hline Total nitrate plus nitrite, $\mathrm{mg} / \mathrm{L}$ as $\mathrm{N}$ & 2.00 & $(27)$ & 1.69 & (99) & .252 & $*$ & 1.252 & 0 & 0 \\
\hline Total nitrite, $\mathrm{mg} / \mathrm{L}$ as $\mathrm{N}$ & .020 & $(27)$ & .018 & (80) & 0 & * & .866 & NA & NA \\
\hline $\begin{array}{l}\text { Total ammonia plus organic nitrogen, } \\
\mathrm{mg} / \mathrm{L} \text { as } \mathrm{N}\end{array}$ & .47 & (27) & .50 & (106) & 0 & * & 1.141 & 0 & 0 \\
\hline Total ammonia, $\mathrm{mg} / \mathrm{L}$ as $\mathrm{N}$ & .08 & (27) & .09 & (95) & 0 & & 1.093 & 0 & NA \\
\hline Total boron, $\mu \mathrm{g} / \mathrm{L}$ as $\mathrm{B}$ & 40 & (7) & 40 & (17) & 0 & & .779 & NA & NA \\
\hline Total lead, $\mu \mathrm{g} / \mathrm{L}$ as $\mathrm{Pb}$ & 1 & (7) & 2 & (21) & .770 & & 1.770 & NA & NA \\
\hline Fecal coliform bacteria, MPN/100 ml & 340 & $(25)$ & 230 & $(107)$ & 0 & * & ND & 0 & 0 \\
\hline
\end{tabular}

Table 27b. 1993 AMNET impairment status in the vicinity of water-quality station 01477120, Raccoon Creek near Swedesboro, N.J.

[AMNET, Ambient Biomonitoring Network; WQ, water-quality. Upstream from WQ station is within 5 miles upstream from the WQ station; at WQ-station location is within 0.5 mile upstream or downstream from the WQ station; downstream from WQ station is within 5 miles downstream from the WQ station; ND, undetermined impairment status]

\begin{tabular}{lccc}
\hline & Upstream from WQ station & At WQ-station location & Downstream from WQ station \\
\hline AMNET station & AN0680 & AN0683 & AN0685 \\
Impairment status & Moderately impaired & Moderately impaired & Moderately impaired \\
\hline
\end{tabular}


Table 28a. Median concentrations, relations of concentration and load to streamflow, and directions of concentration trends for selected waterquality constituents at water-quality station 01477510, Oldmans Creek at Porches Mill, N.J.

[Number in parenthesis is the number of available data values; WY, water years; $\mathrm{mg} / \mathrm{L}$, milligrams per liter; $\mathrm{CaCO}_{3}$, calcium carbonate; $\mathrm{C}$, carbon; Na, sodium; $\mathrm{Cl}$, chloride; \%, percent; $\mathrm{P}$, phosphorus; $\mathrm{N}$, nitrogen; $\mu \mathrm{g} / \mathrm{L}$, micrograms per liter; $\mathrm{B}$, boron; Pb, lead; MPN/100 mL, most probable number per 100 milliliters. Regression slopes and trend directions are zero when the slope is not different from zero at the 0.05 significance level; * indicates seasonal dependency (the slope and (or) intercept of growing (April through October) and non-growing (November through March) season data were different at the 0.05 significance level); +, positive trend direction; -, negative trend direction; NA, insufficient data for analysis; ND, undetermined value]

\begin{tabular}{|c|c|c|c|c|c|c|c|c|c|}
\hline \multirow{3}{*}{$\begin{array}{c}\text { Constituent } \\
\text { Alkalinity, } \mathrm{mg} / \mathrm{L} \text { as } \mathrm{CaCO}_{3}\end{array}$} & \multicolumn{2}{|c|}{ 1989-93 WY } & \multicolumn{7}{|c|}{ 1976-93 WY } \\
\hline & \multicolumn{2}{|c|}{$\begin{array}{l}\text { Median } \\
\text { concentration }\end{array}$} & \multicolumn{2}{|c|}{$\begin{array}{c}\text { Median } \\
\text { concentration }\end{array}$} & \multicolumn{2}{|c|}{$\begin{array}{l}\text { Regression } \\
\text { slope of } \\
\text { concentration to } \\
\text { streamflow }\end{array}$} & \multirow{2}{*}{$\begin{array}{c}\begin{array}{c}\text { Regression } \\
\text { slope of } \\
\text { load to } \\
\text { streamflow }\end{array} \\
0.622\end{array}$} & \multirow{2}{*}{$\begin{array}{c}\begin{array}{c}\text { Low- } \\
\text { flow } \\
\text { trend } \\
\text { direction }\end{array} \\
\text { NA }\end{array}$} & \multirow{2}{*}{$\begin{array}{c}\begin{array}{c}\text { High- } \\
\text { flow } \\
\text { trend } \\
\text { direction }\end{array} \\
\text { NA }\end{array}$} \\
\hline & 25 & $(27)$ & 26 & (73) & -0.378 & $*$ & & & \\
\hline Hardness, $\mathrm{mg} / \mathrm{L}$ as $\mathrm{CaCO}_{3}$ & 60 & $(27)$ & 69 & $(108)$ & -.156 & & .843 & 0 & NA \\
\hline Total organic carbon, $\mathrm{mg} / \mathrm{L}$ as $\mathrm{C}$ & 4.6 & $(27)$ & 4.6 & $(110)$ & 0 & $*$ & 1.034 & 0 & NA \\
\hline Suspended sediment, mg/L & 10 & (9) & 16 & $(20)$ & 0 & & 1.439 & NA & NA \\
\hline Dissolved solids, mg/L & 120 & $(26)$ & 124 & $(101)$ & -.087 & & .913 & 0 & NA \\
\hline Dissolved sodium, $\mathrm{mg} / \mathrm{L}$ as $\mathrm{Na}$ & 5 & $(27)$ & 4 & $(108)$ & 0 & $*$ & .962 & + & NA \\
\hline Dissolved chloride, $\mathrm{mg} / \mathrm{L}$ as $\mathrm{Cl}$ & 16 & $(27)$ & 14 & $(109)$ & -.077 & & .922 & 0 & NA \\
\hline Dissolved oxygen, $\mathrm{mg} / \mathrm{L}$ & 9.6 & (27) & 9.0 & (110) & .097 & * & 1.097 & 0 & NA \\
\hline $\begin{array}{l}\text { Fraction of dissolved oxygen at } \\
\text { saturation, } \%\end{array}$ & 88 & $(25)$ & 90 & $(107)$ & 0 & & ND & + & NA \\
\hline Total phosphorus, $\mathrm{mg} / \mathrm{L}$ as $\mathrm{P}$ & .08 & $(27)$ & .10 & (79) & 0 & * & 1.092 & NA & NA \\
\hline Total nitrogen, $\mathrm{mg} / \mathrm{L}$ as $\mathrm{N}$ & 2.2 & $(27)$ & 2.4 & (99) & .201 & $*$ & 1.201 & 0 & NA \\
\hline Total nitrate plus nitrite, $\mathrm{mg} / \mathrm{L}$ as $\mathrm{N}$ & 1.66 & $(27)$ & 1.66 & $(100)$ & .292 & * & 1.292 & 0 & NA \\
\hline Total nitrite, $\mathrm{mg} / \mathrm{L}$ as $\mathrm{N}$ & .023 & $(26)$ & .019 & $(80)$ & 0 & $*$ & 1.044 & NA & NA \\
\hline $\begin{array}{l}\text { Total ammonia plus organic nitrogen, } \\
\mathrm{mg} / \mathrm{L} \text { as } \mathrm{N}\end{array}$ & .54 & $(27)$ & .60 & $(108)$ & 0 & $*$ & .924 & 0 & NA \\
\hline Total ammonia, $\mathrm{mg} / \mathrm{L}$ as $\mathrm{N}$ & .06 & $(27)$ & .09 & (96) & 0 & & .964 & 0 & NA \\
\hline Total boron, $\mu \mathrm{g} / \mathrm{L}$ as $\mathrm{B}$ & 20 & (6) & 20 & (17) & ND & & 0 & NA & NA \\
\hline Total lead, $\mu \mathrm{g} / \mathrm{L}$ as $\mathrm{Pb}$ & 1 & (7) & 3 & $(21)$ & 0 & & 0 & NA & NA \\
\hline Fecal coliform bacteria, MPN/100 ml & 110 & $(25)$ & 170 & $(105)$ & 0 & $*$ & ND & 0 & NA \\
\hline
\end{tabular}

Table 28b. 1993 AMNET impairment status in the vicinity of water-quality station 01477510, Oldmans Creek at Porches Mill, N.J.

[AMNET, Ambient Biomonitoring Network; WQ, water-quality. Upstream from WQ station is within 5 miles upstream from the WQ station; at WQ-station location is within 0.5 mile upstream or downstream from the WQ station; downstream from WQ station is within 5 miles downstream from the WQ station; ND, undetermined impairment status]

\begin{tabular}{lccr}
\hline & Upstream from WQ station & At WQ-station location & Downstream from WQ station \\
\hline AMNET station & AN0687 & AN0688 & AN0689 \\
Impairment status & Moderately impaired & Moderately impaired & Moderately impaired \\
\hline
\end{tabular}


show seasonal dependency. The regression slope of load to streamflow is in the high range for NA, indicating a larger contribution from storm runoff relative to that at other sites in the study area. The load slopes are in the low range for HARD, TOC, TAON, B, and PB, indicating smaller contributions of these constituents from storm runoff relative to that at other sites in the study area. During low flows, the trends are positive for NA and FDO, indicating an increase in the contributions of these constituents from point sources and ground water over time. Trends are insignificant for HARD, TOC, DS, CL, DO, TN, NO32, TAON, NH4, and BACT during low flows. Insufficient data are available to determine trends for all other constituents during low flows and for all constituents during high flows. The AMNET impairment status is moderately impaired at and upstream and downstream from station 01477510 (table 28b).

\section{Salem River}

For the one station on the Salem River, station 01482500 at Woodstown, the 5-year and period-of-record medians are similar for all constituents (table 29a). The regression slopes of concentration to streamflow for ALK, HARD, TOC, SS, NA, CL, DO, TP, TN, NO32, NO2, and TAON show seasonal dependency. The regression slopes of load to streamflow are in the high range for ALK, TN, NO32, and NO2, indicating larger contributions of these constituents from storm runoff relative to that at other sites in the study area. The load slope for NO32 at station 01482500 is the largest for NO32 in the study area. The load slopes are in the low range for TOC and SS, indicating smaller contributions of these constituents from storm runoff relative to that at other sites in the study area. The load slope for TOC at station 01482500 is the smallest for this constituent in the study area. During low flows, the trend is positive for NA, CL and BACT, indicating an increase in the contributions of these constituents from point sources and ground water over time. Trends are insignificant for HARD, TOC, DS, DO, FDO, TN, NO32, TAON, and NH4 during low flows. Insufficient data are available to determine trends for all other constituents during low flows and for all constituents during high flows. The AMNET impairment status is severely impaired at station 01482500 and moderately impaired upstream and downstream from the station (table 29b).

\section{Delaware Bay Basin}

Three water-quality stations are located on two streams in the Delaware Bay Basin. One station is located on the Cohansey River and two stations are located on the Maurice River.

\section{Cohansey River}

For the one station on the Cohansey River, station 01412800 at Seeley, the 5-year and period-of-record medians are similar for all constituents (table 30a). The period-of-record median for NO32 is the largest for NO32 at all stations in the study area. The regression slopes of concentration to streamflow for ALK, TOC, DO, TN, NO32, NO2, and BACT show seasonal dependency. The regression slopes of load to streamflow are in the high range for ALK, TP, NO2, and $\mathrm{B}$, indicating greater contributions of these constituents from surface runoff relative to that at other sites in the study area. The load slopes for TP and NO2 are the largest for these constituents in the study area. The load slopes are in the low range for DS, NA, and CL, indicating smaller 
Table 29a. Median concentrations, relations of concentration and load to streamflow, and directions of concentration trends for selected waterquality constituents at water-quality station 01482500 , Salem River at Woodstown, N.J.

[Number in parenthesis is the number of available data values; WY, water years; $\mathrm{mg} / \mathrm{L}$, milligrams per liter; $\mathrm{CaCO}_{3}$, calcium carbonate; $\mathrm{C}$, carbon; Na, sodium; $\mathrm{Cl}$, chloride; \%, percent; $\mathrm{P}$, phosphorus; $\mathrm{N}$, nitrogen; $\mu \mathrm{g} / \mathrm{L}$, micrograms per liter; $\mathrm{B}$, boron; Pb, lead; MPN/100 mL, most probable number per 100 milliliters. Regression slopes and trend directions are zero when the slope is not different from zero at the 0.05 significance level; * indicates seasonal dependency (the slope and (or) intercept of growing (April through October) and non-growing (November through March) season data were different at the 0.05 significance level); +, positive trend direction; -, negative trend direction; NA, insufficient data for analysis; ND, undetermined value]

\begin{tabular}{|c|c|c|c|c|c|c|c|c|c|}
\hline \multirow{3}{*}{$\begin{array}{c}\text { Constituent } \\
\text { Alkalinity, } \mathrm{mg} / \mathrm{L} \text { as } \mathrm{CaCO}_{3}\end{array}$} & \multicolumn{2}{|c|}{ 1989-93 WY } & \multicolumn{7}{|c|}{ 1976-93 WY } \\
\hline & \multicolumn{2}{|c|}{$\begin{array}{l}\text { Median } \\
\text { concentration }\end{array}$} & \multicolumn{2}{|c|}{$\begin{array}{c}\text { Median } \\
\text { concentration }\end{array}$} & \multicolumn{2}{|c|}{$\begin{array}{l}\text { Regression } \\
\text { slope of } \\
\text { concentration to } \\
\text { streamflow }\end{array}$} & \multirow{2}{*}{$\begin{array}{c}\begin{array}{c}\text { Regression } \\
\text { slope of } \\
\text { load to } \\
\text { streamflow }\end{array} \\
0.736\end{array}$} & \multirow{2}{*}{$\begin{array}{c}\begin{array}{c}\text { Low- } \\
\text { flow } \\
\text { trend } \\
\text { direction }\end{array} \\
\text { NA }\end{array}$} & \multirow{2}{*}{$\begin{array}{c}\begin{array}{c}\text { High- } \\
\text { flow } \\
\text { trend } \\
\text { direction }\end{array} \\
\text { NA }\end{array}$} \\
\hline & 28 & $(27)$ & 28 & (74) & -0.264 & $*$ & & & \\
\hline Hardness, $\mathrm{mg} / \mathrm{L}$ as $\mathrm{CaCO}_{3}$ & 79 & $(27)$ & 78 & (109) & -.088 & $*$ & .912 & 0 & NA \\
\hline Total organic carbon, $\mathrm{mg} / \mathrm{L}$ as $\mathrm{C}$ & 8.4 & $(25)$ & 7.0 & $(109)$ & -.160 & $*$ & .839 & 0 & NA \\
\hline Suspended sediment, mg/L & 28 & $(10)$ & 23 & $(25)$ & 0 & $*$ & 1.065 & NA & NA \\
\hline Dissolved solids, mg/L & 144 & $(26)$ & 143 & $(106)$ & -.048 & & .952 & 0 & NA \\
\hline Dissolved sodium, $\mathrm{mg} / \mathrm{L}$ as $\mathrm{Na}$ & 7 & $(27)$ & 7 & $(108)$ & -.088 & $*$ & .912 & + & NA \\
\hline Dissolved chloride, $\mathrm{mg} / \mathrm{L}$ as $\mathrm{Cl}$ & 21 & $(27)$ & 19 & $(109)$ & -.073 & $*$ & .927 & + & NA \\
\hline Dissolved oxygen, $\mathrm{mg} / \mathrm{L}$ & 9.0 & $(27)$ & 8.8 & (111) & .098 & * & 1.098 & 0 & NA \\
\hline $\begin{array}{l}\text { Fraction of dissolved oxygen at } \\
\text { saturation, } \%\end{array}$ & 91 & $(26)$ & 95 & $(108)$ & 0 & & ND & 0 & NA \\
\hline Total phosphorus, $\mathrm{mg} / \mathrm{L}$ as $\mathrm{P}$ & .16 & (27) & .17 & (79) & 0 & * & .918 & NA & NA \\
\hline Total nitrogen, $\mathrm{mg} / \mathrm{L}$ as $\mathrm{N}$ & 3.8 & $(27)$ & 3.4 & $(98)$ & .351 & $*$ & 1.350 & 0 & NA \\
\hline Total nitrate plus nitrite, $\mathrm{mg} / \mathrm{L}$ as $\mathrm{N}$ & 2.0 & (27) & 1.98 & $(100)$ & 1.171 & * & 2.171 & 0 & NA \\
\hline Total nitrite, $\mathrm{mg} / \mathrm{L}$ as $\mathrm{N}$ & .044 & $(26)$ & .040 & (79) & .388 & $*$ & 1.388 & NA & NA \\
\hline $\begin{array}{l}\text { Total ammonia plus organic nitrogen, } \\
\mathrm{mg} / \mathrm{L} \text { as } \mathrm{N}\end{array}$ & 1.43 & $(27)$ & 1.30 & $(108)$ & 0 & $*$ & 1.024 & 0 & NA \\
\hline Total ammonia, $\mathrm{mg} / \mathrm{L}$ as $\mathrm{N}$ & .16 & $(27)$ & .19 & $(98)$ & .378 & & 1.377 & 0 & NA \\
\hline Total boron, $\mu \mathrm{g} / \mathrm{L}$ as $\mathrm{B}$ & 20 & (6) & 30 & (19) & 0 & & .962 & NA & NA \\
\hline Total lead, $\mu \mathrm{g} / \mathrm{L}$ as $\mathrm{Pb}$ & 2 & (6) & 5 & (19) & 0 & & 1.120 & NA & NA \\
\hline Fecal coliform bacteria, MPN/100 ml & 350 & $(25)$ & 170 & $(107)$ & .929 & & ND & + & NA \\
\hline
\end{tabular}

Table 29b. 1993 AMNET impairment status in the vicinity of water-quality station 01482500, Salem River at Woodstown, N.J.

[AMNET, Ambient Biomonitoring Network; WQ, water-quality. Upstream from WQ station is within 5 miles upstream from the WQ station; at WQ-station location is within 0.5 mile upstream or downstream from the WQ station; downstream from WQ station is within 5 miles downstream from the WQ station; ND, undetermined impairment status]

\begin{tabular}{lccc}
\hline & Upstream from WQ station & At WQ-station location & Downstream from WQ station \\
\hline AMNET station & AN0690 & AN0691 & AN0693 \\
Impairment status & Moderately impaired & Severely impaired & Moderately impaired \\
\hline
\end{tabular}


Table 30a. Median concentrations, relations of concentration and load to streamflow, and directions of concentration trends for selected waterquality constituents at water-quality station 01412800, Cohansey River at Seeley, N.J.

[Number in parenthesis is the number of available data values; WY, water years; $\mathrm{mg} / \mathrm{L}$, milligrams per liter; $\mathrm{CaCO}_{3}$, calcium carbonate; $\mathrm{C}$, carbon; Na, sodium; $\mathrm{Cl}$, chloride; \%, percent; $\mathrm{P}$, phosphorus; $\mathrm{N}$, nitrogen; $\mu \mathrm{g} / \mathrm{L}$, micrograms per liter; $\mathrm{B}$, boron; $\mathrm{Pb}$, lead; MPN/100 mL, most probable number per 100 milliliters. Regression slopes and trend directions are zero when the slope is not different from zero at the 0.05 significance level; * indicates seasonal dependency (the slope and (or) intercept of growing (April through October) and non-growing (November through March) season data were different at the 0.05 significance level); +, positive trend direction; -, negative trend direction; NA, insufficient data for analysis; ND, undetermined value]

\begin{tabular}{|c|c|c|c|c|c|c|c|c|c|}
\hline \multirow{3}{*}{$\begin{array}{l}\text { Constituent } \\
\text { ag/L as } \mathrm{CaCO}_{3}\end{array}$} & \multicolumn{2}{|c|}{ 1989-93 WY } & \multicolumn{7}{|c|}{ 1976-93 WY } \\
\hline & \multicolumn{2}{|c|}{$\begin{array}{c}\text { Median } \\
\text { concentration }\end{array}$} & \multicolumn{2}{|c|}{$\begin{array}{c}\text { Median } \\
\text { concentration }\end{array}$} & \multicolumn{2}{|c|}{$\begin{array}{c}\text { Regression } \\
\text { slope of } \\
\text { concentration to } \\
\text { streamflow }\end{array}$} & \multirow{2}{*}{$\begin{array}{c}\begin{array}{c}\text { Regression } \\
\text { slope of } \\
\text { load to } \\
\text { streamflow }\end{array} \\
0.871\end{array}$} & \multirow{2}{*}{$\begin{array}{c}\text { Low- } \\
\text { flow } \\
\text { trend } \\
\text { direction } \\
\text { NA }\end{array}$} & \multirow{2}{*}{$\begin{array}{c}\text { High- } \\
\text { flow } \\
\text { trend } \\
\text { direction } \\
\text { NA }\end{array}$} \\
\hline & 17 & (27) & 14 & (73) & 0 & * & & & \\
\hline Hardness, $\mathrm{mg} / \mathrm{L}$ as $\mathrm{CaCO}_{3}$ & 58 & $(27)$ & 56 & $(110)$ & -.053 & & .947 & 0 & 0 \\
\hline Total organic carbon, $\mathrm{mg} / \mathrm{L}$ as $\mathrm{C}$ & 3.9 & (27) & 3.9 & $(108)$ & .344 & $*$ & 1.343 & 0 & 0 \\
\hline Suspended sediment, $\mathrm{mg} / \mathrm{L}$ & 14 & (9) & 9 & (23) & .755 & & 1.754 & NA & NA \\
\hline Dissolved solids, $\mathrm{mg} / \mathrm{L}$ & 126 & (26) & 130 & (103) & -.129 & & .871 & 0 & 0 \\
\hline Dissolved sodium, $\mathrm{mg} / \mathrm{L}$ as $\mathrm{Na}$ & 10 & $(27)$ & 12 & $(110)$ & -.384 & & .616 & 0 & 0 \\
\hline Dissolved chloride, $\mathrm{mg} / \mathrm{L}$ as $\mathrm{Cl}$ & 25 & $(27)$ & 26 & $(110)$ & -.268 & & .731 & - & 0 \\
\hline Dissolved oxygen, $\mathrm{mg} / \mathrm{L}$ & 8.9 & $(27)$ & 8.7 & $(110)$ & 0 & $*$ & 1.082 & 0 & 0 \\
\hline $\begin{array}{l}\text { Fraction of dissolved oxygen at } \\
\text { saturation, } \%\end{array}$ & 88 & (26) & 89 & (109) & 0 & & ND & 0 & 0 \\
\hline Total phosphorus, $\mathrm{mg} / \mathrm{L}$ as $\mathrm{P}$ & .08 & $(27)$ & .08 & (79) & .553 & & 1.552 & NA & NA \\
\hline Total nitrogen, $\mathrm{mg} / \mathrm{L}$ as $\mathrm{N}$ & 4.9 & $(27)$ & 4.7 & (96) & 0 & $*$ & .996 & 0 & 0 \\
\hline Total nitrate plus nitrite, $\mathrm{mg} / \mathrm{L}$ as $\mathrm{N}$ & 4.35 & $(27)$ & 4.08 & (99) & 0 & * & .941 & 0 & 0 \\
\hline Total nitrite, $\mathrm{mg} / \mathrm{L}$ as $\mathrm{N}$ & .027 & $(27)$ & .027 & (79) & .442 & $*$ & 1.442 & NA & NA \\
\hline $\begin{array}{l}\text { Total ammonia plus organic nitrogen, } \\
\mathrm{mg} / \mathrm{L} \text { as } \mathrm{N}\end{array}$ & .63 & $(27)$ & .63 & $(105)$ & 0 & & 1.426 & 0 & 0 \\
\hline Total ammonia, $\mathrm{mg} / \mathrm{L}$ as $\mathrm{N}$ & .08 & $(27)$ & .10 & (94) & 0 & & 1.333 & 0 & - \\
\hline Total boron, $\mu \mathrm{g} / \mathrm{L}$ as $\mathrm{B}$ & 11 & (6) & 20 & $(15)$ & 0 & & 1.655 & NA & NA \\
\hline Total lead, $\mu \mathrm{g} / \mathrm{L}$ as $\mathrm{Pb}$ & 2 & (7) & 3 & (17) & 0 & & 1.259 & NA & NA \\
\hline Fecal coliform bacteria, MPN/100 ml & 230 & $(25)$ & 230 & $(105)$ & 1.382 & * & ND & 0 & 0 \\
\hline
\end{tabular}

Table 30b. 1993 AMNET impairment status in the vicinity of water-quality station 01412800, Cohansey River at Seeley, N.J.

[AMNET, Ambient Biomonitoring Network; WQ, water-quality. Upstream from WQ station is within 5 miles upstream from the WQ station; at WQ-station location is within 0.5 mile upstream or downstream from the WQ station; downstream from WQ station is within 5 miles downstream from the WQ station; ND, undetermined impairment status]

\begin{tabular}{lccc}
\hline & Upstream from WQ station & At WQ-station location & Downstream from WQ station \\
\hline AMNET station & AN0710 & AN0712 & None \\
Impairment status & Moderately impaired & Moderately impaired & ND \\
\hline
\end{tabular}


contributions of these constituents from storm runoff relative to that at other sites in the study area. During low flows, the trend is negative for CL, indicating a decrease in the contributions of these constituents from point sources and ground water over time. Trends during low flows are insignificant for HARD, TOC, DS, NA, DO, FDO, TN, NO32, TAON, NH4, and BACT. During high flows, the trend is negative for $\mathrm{NH} 4$, indicating a decrease in the contribution from storm runoff over time. Trends during high flows are insignificant for HARD, TOC, DS, NA, CL, DO, FDO, TN, NO32, TAON, and BACT. Insufficient data are available to determine trends for ALK, $\mathrm{SS}, \mathrm{TP}, \mathrm{NO} 2, \mathrm{~B}$, and PB during low and high flows. The AMNET impairment status is moderately impaired at and upstream from station 01412800 (table 30b).

\section{$\underline{\text { Maurice River }}$}

The Maurice River Basin has two water-quality stations both on the Maurice Riverstations 01411500 at Norma and 01411800 near Millville. The 5-year and period-of-record medians are similar for all constituents at both stations (tables 31a and 32a). The regression slopes of concentration to streamflow for ALK, HARD, TOC, SS, CL, DO, FDO, TP, TN, NO32, TAON, and BACT show seasonal dependency at station 01411500. The concentration slopes for DO, FDO, TN, NO32, NO2, TAON, and BACT show seasonal dependency at station 01411800.

The regression slope of load to streamflow is in the high range only for TOC at station 01411500, indicating a greater contribution from storm runoff relative to that at other sites in the study area. Load slopes are in the low range for TN and NO32 at station 01411500 and for TAON, NH4, and PB at station 01411800 , indicating smaller contributions of these constituents from storm runoff relative to that at other sites in the study area. The load slopes for DO at station 01411500 and NH4 at station 01411800 are the smallest for these constituents in the study area. The load slopes of TOC, NA, CL, TAON, and NH4 decrease in the downstream direction, indicating a decrease in the contributions of these constituents from storm runoff along the Maurice River. The load slopes of TP, TN, and NO32 increase in the downstream direction, indicating an increase in the contributions of these constituents from storm runoff along the Maurice River.

During low flows at station 01411500, the trend is positive for HARD and CL, indicating an increase in the contributions of these constituents from points sources and ground water over time, and negative for NA, indicating a decrease in the contributions of NA from points sources and ground water over time. Trends during low flows at station 01411500 are insignificant for DS, DO, FDO, TP, TN, NO32, and TAON. During high flows at station 01411500, the trend is positive for HARD, indicating an increase in the contribution from storm runoff over time, and negative for DS and TP, indicating a decrease in the contributions of these constituents from storm runoff over time. Trends during high flows at station 01411500 are insignificant for NA, CL, DO, FDO, TN, NO32, and TAON. Insufficient data are available at station 01411500 to determine trends for ALK, TOC, SS, NO2, NH4, B, PB, and BACT during low and high flows. During low flows at station 01411800, trends are insignificant for DO, FDO, TN, NO32, NO2, TAON, NH4, and BACT. Insufficient data are available at station 01411800 to determine trends for all other constituents during low flows and for all constituents during high flows. 
Table 31a. Median concentrations, relations of concentration and load to streamflow, and directions of concentration trends for selected waterquality constituents at water-quality station 01411500, Maurice River at Norma, N.J.

[Number in parenthesis is the number of available data values; WY, water years; $\mathrm{mg} / \mathrm{L}$, milligrams per liter; $\mathrm{CaCO}_{3}$, calcium carbonate; $\mathrm{C}$, carbon; Na, sodium; $\mathrm{Cl}$, chloride; \%, percent; $\mathrm{P}$, phosphorus; $\mathrm{N}$, nitrogen; $\mu \mathrm{g} / \mathrm{L}$, micrograms per liter; $\mathrm{B}$, boron; $\mathrm{Pb}$, lead; MPN/100 mL, most probable number per 100 milliliters. Regression slopes and trend directions are zero when the slope is not different from zero at the 0.05 significance level; * indicates seasonal dependency (the slope and (or) intercept of growing (April through October) and non-growing (November through March) season data were different at the 0.05 significance level); +, positive trend direction; -, negative trend direction; NA, insufficient data for analysis; ND, undetermined value]

\begin{tabular}{|c|c|c|c|c|c|c|c|c|c|}
\hline \multirow{3}{*}{$\begin{array}{c}\text { Constituent } \\
\text { Alkalinity, } \mathrm{mg} / \mathrm{L} \text { as } \mathrm{CaCO}_{3}\end{array}$} & \multicolumn{2}{|c|}{ 1989-93 WY } & \multicolumn{7}{|c|}{ 1976-93 WY } \\
\hline & \multicolumn{2}{|c|}{$\begin{array}{c}\text { Median } \\
\text { concentration }\end{array}$} & \multicolumn{2}{|c|}{$\begin{array}{l}\text { Median } \\
\text { concentration }\end{array}$} & \multicolumn{2}{|c|}{$\begin{array}{l}\text { Regression } \\
\text { slope of } \\
\text { concentration to } \\
\text { streamflow }\end{array}$} & \multirow{2}{*}{$\begin{array}{c}\begin{array}{c}\text { Regression } \\
\text { slope of } \\
\text { load to } \\
\text { streamflow }\end{array} \\
0.459\end{array}$} & \multirow{2}{*}{$\begin{array}{c}\begin{array}{c}\text { Low- } \\
\text { flow } \\
\text { trend } \\
\text { direction }\end{array} \\
\text { NA }\end{array}$} & \multirow{2}{*}{$\begin{array}{c}\begin{array}{c}\text { High- } \\
\text { flow } \\
\text { trend } \\
\text { direction }\end{array} \\
\mathrm{NA}\end{array}$} \\
\hline & 6 & $(30)$ & 6 & $(77)$ & -0.540 & $*$ & & & \\
\hline Hardness, $\mathrm{mg} / \mathrm{L}$ as $\mathrm{CaCO}_{3}$ & 20 & $(30)$ & 18 & $(118)$ & -.060 & $*$ & .940 & + & + \\
\hline Total organic carbon, $\mathrm{mg} / \mathrm{L}$ as $\mathrm{C}$ & ND & $(0)$ & 5.8 & $(62)$ & .585 & * & 1.584 & NA & NA \\
\hline Suspended sediment, $\mathrm{mg} / \mathrm{L}$ & 6 & $(29)$ & 5 & $(100)$ & .582 & $*$ & 1.582 & NA & NA \\
\hline Dissolved solids, $\mathrm{mg} / \mathrm{L}$ & 56 & $(30)$ & 57 & $(118)$ & .057 & & 1.057 & 0 & - \\
\hline Dissolved sodium, $\mathrm{mg} / \mathrm{L}$ as $\mathrm{Na}$ & 5 & $(30)$ & 5 & $(119)$ & -.072 & & .928 & - & 0 \\
\hline Dissolved chloride, $\mathrm{mg} / \mathrm{L}$ as $\mathrm{Cl}$ & 9 & $(30)$ & 9 & $(121)$ & 0 & * & .980 & + & 0 \\
\hline Dissolved oxygen, $\mathrm{mg} / \mathrm{L}$ & 8.6 & $(30)$ & 8.8 & $(123)$ & 0 & * & .986 & 0 & 0 \\
\hline $\begin{array}{l}\text { Fraction of dissolved oxygen at } \\
\text { saturation, } \%\end{array}$ & 88 & $(29)$ & 88 & $(120)$ & -.068 & * & ND & 0 & 0 \\
\hline Total phosphorus, $\mathrm{mg} / \mathrm{L}$ as $\mathrm{P}$ & .01 & $(30)$ & .02 & (116) & 0 & $*$ & 1.037 & 0 & - \\
\hline Total nitrogen, $\mathrm{mg} / \mathrm{L}$ as $\mathrm{N}$ & 1.9 & $(29)$ & 1.9 & $(108)$ & -.179 & $*$ & .821 & 0 & 0 \\
\hline Total nitrate plus nitrite, $\mathrm{mg} / \mathrm{L}$ as $\mathrm{N}$ & 1.50 & $(29)$ & 1.50 & $(110)$ & -.351 & $*$ & .648 & 0 & 0 \\
\hline Total nitrite, $\mathrm{mg} / \mathrm{L}$ as $\mathrm{N}$ & .006 & $(20)$ & .008 & (34) & 0 & & .918 & NA & NA \\
\hline $\begin{array}{l}\text { Total ammonia plus organic nitrogen, } \\
\mathrm{mg} / \mathrm{L} \text { as } \mathrm{N}\end{array}$ & .40 & $(30)$ & .50 & $(120)$ & .192 & * & 1.192 & 0 & 0 \\
\hline Total ammonia, $\mathrm{mg} / \mathrm{L}$ as $\mathrm{N}$ & .04 & $(25)$ & .04 & $(81)$ & 0 & & .977 & NA & NA \\
\hline Total boron, $\mu \mathrm{g} / \mathrm{L}$ as $\mathrm{B}$ & ND & $(0)$ & 40 & (3) & ND & & ND & NA & NA \\
\hline Total lead, $\mu \mathrm{g} / \mathrm{L}$ as $\mathrm{Pb}$ & ND & $(0)$ & 5 & (16) & 0 & & 1.025 & NA & NA \\
\hline Fecal coliform bacteria, MPN/100 ml & $\mathrm{ND}$ & $(0)$ & 33 & (44) & 0 & * & ND & NA & NA \\
\hline
\end{tabular}

Table 31b. 1993 AMNET impairment status in the vicinity of water-quality station 01411500, Maurice River at Norma, N.J.

[AMNET, Ambient Biomonitoring Network; WQ, water-quality. Upstream from WQ station is within 5 miles upstream from the WQ station; at WQ-station location is within 0.5 mile upstream or downstream from the WQ station; downstream from WQ station is within 5 miles downstream from the WQ station; ND, undetermined impairment status]

\begin{tabular}{lccc}
\hline & Upstream from WQ station & At WQ-station location & Downstream from WQ station \\
\hline AMNET station & AN0733 & AN0740 & AN0751 \\
Impairment status & Moderately impaired & Non-impaired & Moderately impaired \\
\hline
\end{tabular}


Table 32a. Median concentrations, relations of concentration and load to streamflow, and directions of concentration trends for selected waterquality constituents at water-quality station 01411800, Maurice River near Millville, N.J.

[Number in parenthesis is the number of available data values; WY, water years; $\mathrm{mg} / \mathrm{L}$, milligrams per liter; $\mathrm{CaCO}_{3}$, calcium carbonate; $\mathrm{C}$, carbon; Na, sodium; $\mathrm{Cl}$, chloride; \%, percent; $\mathrm{P}$, phosphorus; $\mathrm{N}$, nitrogen; $\mu \mathrm{g} / \mathrm{L}$, micrograms per liter; $\mathrm{B}$, boron; Pb, lead; MPN/100 mL, most probable number per 100 milliliters. Regression slopes and trend directions are zero when the slope is not different from zero at the 0.05 significance level; * indicates seasonal dependency (the slope and (or) intercept of growing (April through October) and non-growing (November through March) season data were different at the 0.05 significance level); +, positive trend direction; -, negative trend direction; NA, insufficient data for analysis; ND, undetermined value]

\begin{tabular}{|c|c|c|c|c|c|c|}
\hline \multirow[b]{2}{*}{ Constituent } & \multirow{2}{*}{$\begin{array}{c}\text { 1989-93 WY } \\
\text { Median } \\
\text { concentration }\end{array}$} & \multicolumn{5}{|c|}{ 1976-93 WY } \\
\hline & & $\begin{array}{c}\text { Median } \\
\text { concentration }\end{array}$ & $\begin{array}{c}\text { Regression } \\
\text { slope of } \\
\text { concentration to } \\
\text { streamflow }\end{array}$ & $\begin{array}{l}\text { Regression } \\
\text { slope of } \\
\text { load to } \\
\text { streamflow }\end{array}$ & $\begin{array}{l}\text { Low- } \\
\text { flow } \\
\text { trend } \\
\text { direction }\end{array}$ & $\begin{array}{l}\text { High- } \\
\text { flow } \\
\text { trend } \\
\text { direction }\end{array}$ \\
\hline
\end{tabular}

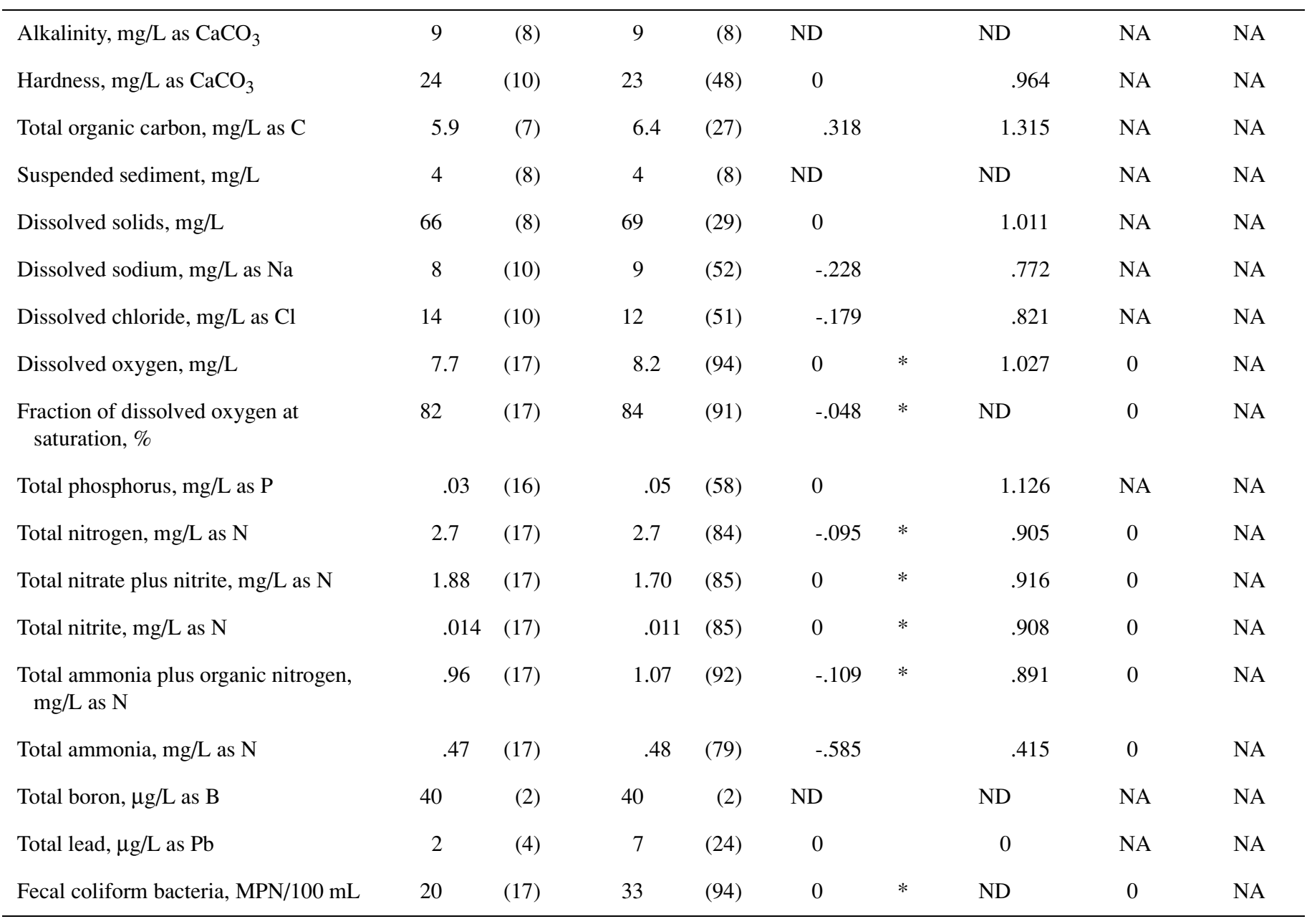

Table 32b. 1993 AMNET impairment status in the vicinity of water-quality station 01411800, Maurice River near Millville, N.J.

[AMNET, Ambient Biomonitoring Network; WQ, water-quality. Upstream from WQ station is within 5 miles upstream from the WQ station; at WQ-station location is within 0.5 mile upstream or downstream from the WQ station; downstream from WQ station is within 5 miles downstream from the WQ station; ND, undetermined impairment status]

\begin{tabular}{lccc}
\hline & Upstream from WQ station & At WQ-station location & Downstream from WQ station \\
\hline AMNET station & AN0740 & AN0751 & None \\
Impairment status & Non-impaired & Moderately impaired & ND \\
\hline
\end{tabular}


The AMNET impairment status is non-impaired at station 01411500 and moderately impaired upstream and downstream from the station (table 31b). The AMNET impairment status is moderately impaired at station 01411800 and non-impaired upstream from the station (table $32 b)$.

\section{$\underline{\text { Analysis of Relations by Constituent }}$}

Schematics of the trends in concentrations during high and low flows and the values of the slopes of load to streamflow are shown by constituent (figs. 8-43). Trends in concentrations for stations in the Atlantic Coastal Basin are shown separately from those for stations in the Lower Delaware and Delaware Bay Basins because of the large number of stations in the study area. Schematics depicting the slopes of load to streamflow are presented for each constituent except dissolved oxygen at saturation and fecal coliform bacteria because loads were not calculated for these two constituents. The 01 prefix and any extraneous ending zeros have been removed from station numbers on the schematics and in the text that follows. Schematics are not drawn to scale. Only results from stations with sufficient data for analysis are discussed. Only two of the 28 water-quality stations have insufficient data for all constituents to determine trends in concentrations during high and low flows-the upstream station on the Assunpink Creek, station 46362, and station 467329 on the South Branch Big Timber Creek.

In the schematics showing trends of concentrations during low and high flows, symbols are used to indicate a positive (increasing concentrations), negative (decreasing concentrations), or no (insignificant change in concentrations) trend (figs. 8-43). Trends in concentrations during high and low flows indicate trends in contributions from intermittent (storm runoff) and constant (point sources and ground water) sources, respectively. Trends in concentrations during high flows indicate changes in the relative contributions from nonpoint sources because storm runoff contributes to a stream during high flows. Trends in concentrations during low flows indicate changes in the relative contributions from point sources and ground water because storm runoff does not contribute to a stream during low flows.

The steepness of the slope of load to streamflow at a site indicates the relative contributions to the instream load from constant and intermittent sources relative to that at other sites in the study area. The larger the contribution from storm runoff, the larger the slope will be because the load will increase with increasing streamflow. Likewise, the larger the contribution from constant sources, the smaller the slope will be because the instream load will be constant with increasing streamflow. In the schematics, symbols are used to indicate the range category of the slope at each station. Filled circles represent stations with slopes in the high range, hashed circles represent stations with slopes in the moderate range, and quartered circles represent stations with slopes in the low range. Open circles indicate stations for which slopes could not be determined because of insufficient data. Only results from stations with slopes in either the high or low range are discussed.

An increase in the magnitude of the slope in the downstream direction along a stream would indicate an increase in the relative contribution to the instream load from the storm runoff and would be evident if the order of circles proceeded from quartered to hashed to solid in the downstream direction. Likewise, a decrease in the magnitude of the slope in the downstream 
direction along a stream would indicate an increase in the relative contribution to the instream load from point sources and ground water and would be evident if the order of circles proceeded from solid to hashed to quartered in the downstream direction.

\section{Alkalinity}

Alkalinity, an aggregate property of water, is a measure of the capacity of water to neutralize acids and is the sum of all the titratable bases in solution (Eaton and others, 1995). The carbonate contributors to alkalinity, carbonate and bicarbonate, result from the dissociation of dissolved carbon dioxide. The important noncarbonate contributors to alkalinity include hydroxides, silicates, borates, phosphates, and organic ligands, especially acetate and propionate. In many surface-water bodies, alkalinity is primarily a function of carbonate, bicarbonate, and hydroxide, and represents their combined concentrations. Alkalinity measurements are important in the evaluation and control of potable water and wastewater processes, including chemical coagulation, water softening, corrosion control, and buffer capacity evaluation. In surface water that supports extensive algal blooms, consumption of carbon dioxide by algae for photosynthesis causes an increase in $\mathrm{pH}$ due to a shift in the forms of alkalinity, although there is no change in the total alkalinity (Sawyer and McCarty, 1978). Alkalinity in excess of alkaline-earth element concentrations could make water unsuitable for irrigation. Carbonate concentrations can be estimated from alkalinity measurements and used to compute the ion balance when checking water analyses.

\section{$\underline{\text { Relation of trends in concentration to flow conditions }}$}

Insufficient data are available to determine trends in alkalinity during high and low flows at all stations in the study area (figs. 8a, 9a, 8b, and 9b).

\section{$\underline{\text { Relation of load to streamflow }}$}

The range categories of regression slopes of alkalinity load to streamflow are depicted in figure $8 \mathrm{c}$ and 9c. The slopes range from zero at stations on the Mullica (409387) and Batsto (4095) Rivers, East Branch of the Bass River (41015), and Great Egg Harbor (4110) River (tables 7a, 9a, 12a, and 14a, respectively) to 0.976 at station 467069 on the North Branch of the Pennsauken River (table 23a). Slopes are in the high range at stations on the Hammonton Creek (409416), West Branch of the Wading River (409815), Doctors Creek (464515), North Branch of the Pennsauken (467069) Creek, Cooper River (46715), South Branch Big Timber Creek (467329), and Salem (4825) and Cohansey (4128) Rivers. At these sites, the contributions to instream alkalinity loads from storm runoff are larger and less influenced by point sources and ground water than at other sites in the study area. Slopes are in the low range at stations on the Mullica (40937), Batsto (4095), and East Branch of the Bass (41015) Rivers, and the downstream stations on the Great Egg Harbor River (4110 and 41111). At these stations, the contributions to instream alkalinity loads from constant sources (most likely ground water) are larger and less influenced by storm runoff than at other sites in the study area. 


\section{Hardness}

Hardness, an aggregate property of water, is an important consideration in determining the suitability of water for domestic and industrial uses. Hardness, historically described as a measure of the capacity of water to precipitate soap, is commonly caused by divalent metallic cations, namely calcium, magnesium, strontium, ferrous iron, and manganous ions (Sawyer and McCarty, 1978). Other polyvalent cations also can precipitate soap, but they often are in complex forms, frequently with organic constituents, and their role in water hardness may be minimal and difficult to define (Eaton and others, 1995). Cation concentrations can be estimated from hardness measurements and used to compute the ion balance when checking water analyses.

Calcium and magnesium, the major contributors to hardness, are often the major cations in surface water. Calcium is the most abundant of the alkaline-earth elements and is a major constituent of many common rock minerals; it is an essential element for plant and animal life. Calcium geochemical behavior is governed by the availability of soluble calcium-containing minerals, solution- and gas-phase equilibria that involve carbon dioxide species, and the availability of sulfur in the form of sulfate (Hem, 1985). Calcium also participates in cationexchange equilibria at aluminosilicate and other mineral surfaces. Calcium salts used for deicing highways can be carried to surface water with storm runoff and melting snow. Magnesium is an alkaline-earth element and is essential in plant and animal nutrition. The water chemistry of calcium and magnesium is similar; however, the geochemical behavior is different. The cationexchange behavior of magnesium is similar to that of calcium.

\section{Relation of trends in concentration to flow conditions}

The trend in hardness concentrations during high flows is positive at the upstream station on the Maurice River (4115), indicating an increase in the contribution from storm runoff over time at this station (figs. 10a and 11a). The trend in hardness concentrations during high flows is negative at the one station on the Toms River (4085), indicating a decrease in the contribution from storm runoff over time at this station. Hardness concentrations during high flows show no trends at the stations on the Raccoon Creek (47712) and Cohansey River (4128). The trends in hardness concentrations during low flows are positive at the one station on the South Branch of the Pennsauken Creek (467081) and the upstream station on the Maurice River (4115), indicating an increase in the contribution from point sources and ground water over time at these stations (figs. 10b and 11b). Hardness concentrations during low flows show no trends at the stations on the Toms River (4085), Hammonton Creek (409416), Batsto River (4095), West Branch of the Wading River (409815), Oswego River (4100) and East Branch of the Bass (41015) River; the downstream stations on the Great Egg Harbor River (4110 and 41111); and the stations on the Crosswicks (4645) and Doctors (464515) Creeks, McDonalds Branch (4665), South (46585) and North (4670) Branches of the Rancocas, North Branch of the Pennsauken (467069), Raccoon (47712), and Oldmans (47751) Creeks, and Salem (4825) and Cohansey (4128) Rivers. 

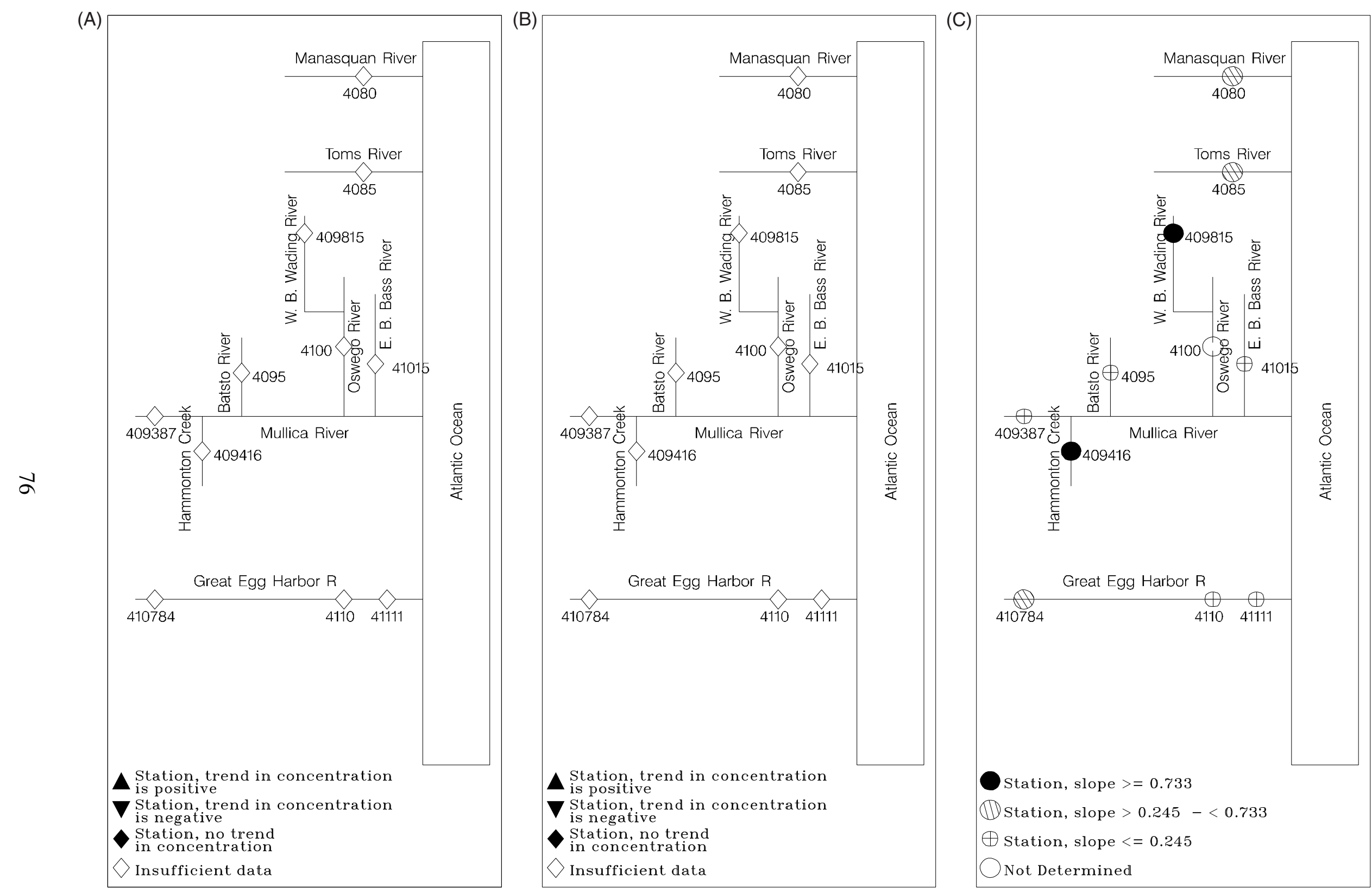

Figure 8. Trends in alkalinity concentrations during (A) high- and (B) low-flow conditions, and (C) relative slope of alkalinity load to streamflow at surface-water-quality stations in the Atlantic Coastal Basins, N.J., water years 1976-93. 

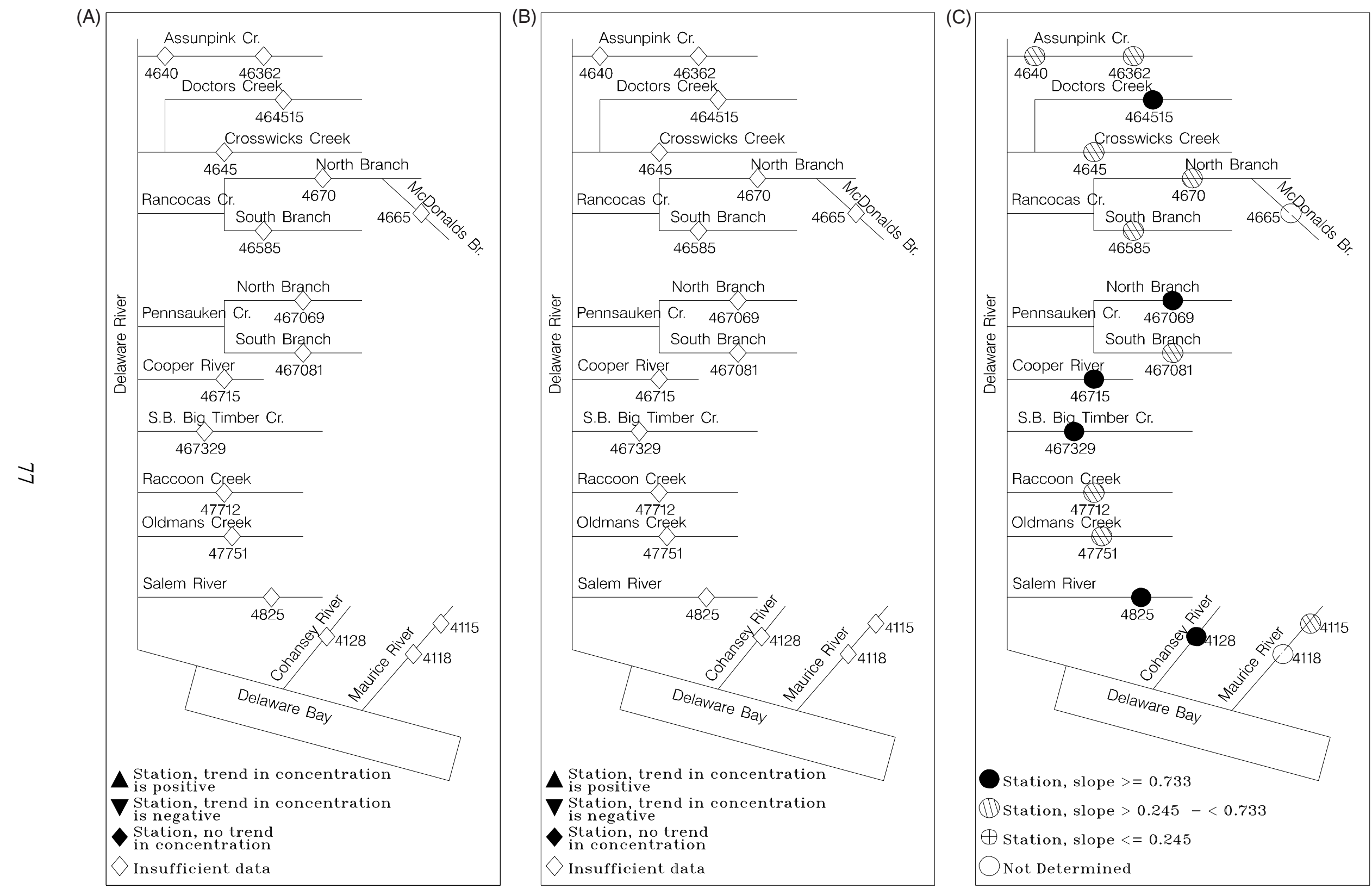

Figure 9. Trends in alkalinity concentrations during (A) high- and (B) low-flow conditions, and (C) relative slope of alkalinity load to streamflow at surface-water-quality stations in the lower Delaware River and Delaware Bay Basins, N.J., water years 1976-93. 

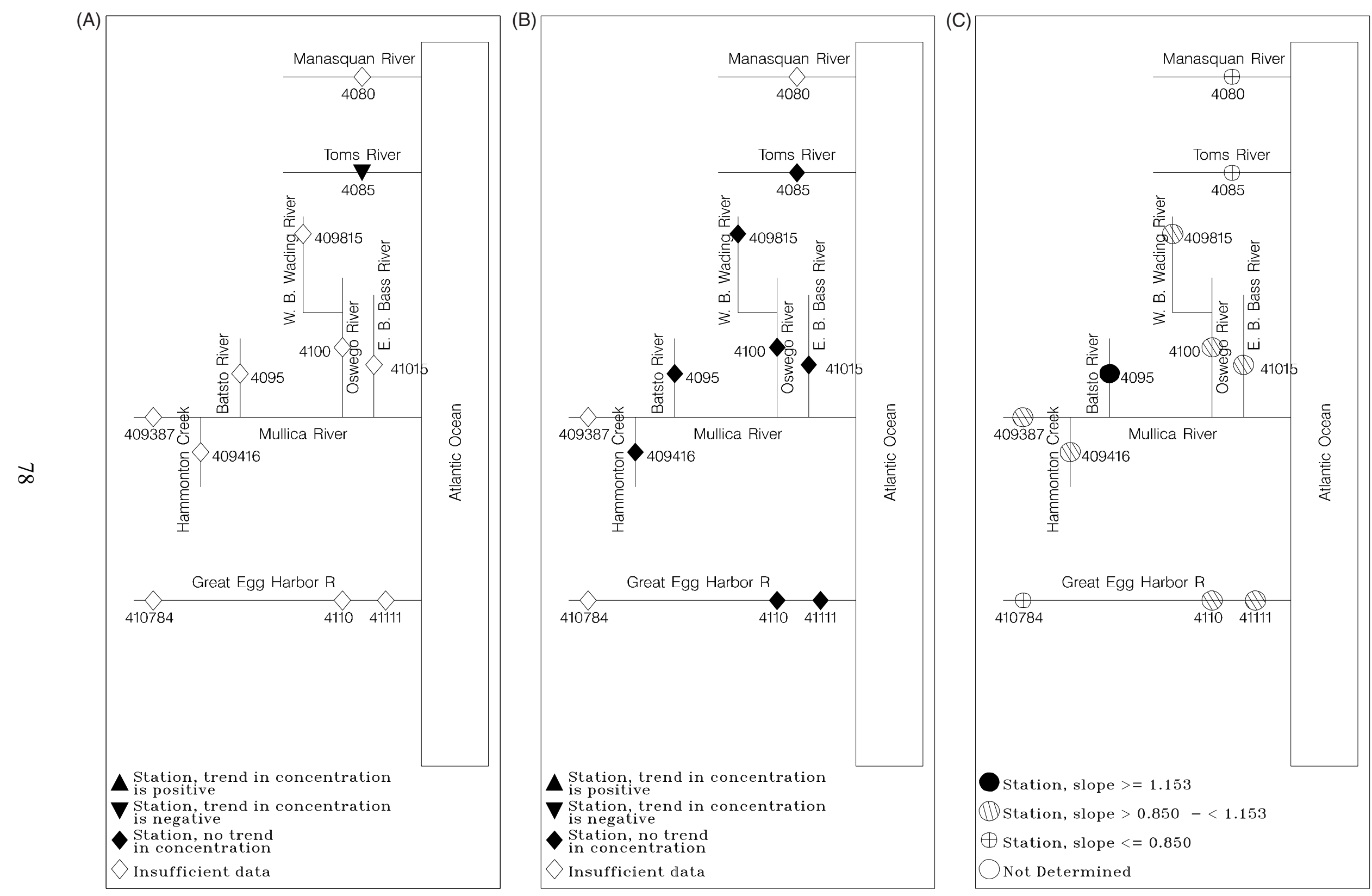

Figure 10. Trends in total hardness concentrations during (A) high- and (B) low-flow conditions, and (C) relative slope of total hardness load to streamflow at surface-water-quality stations in the Atlantic Coastal Basins, N.J., water years 1976-93. 
(A)
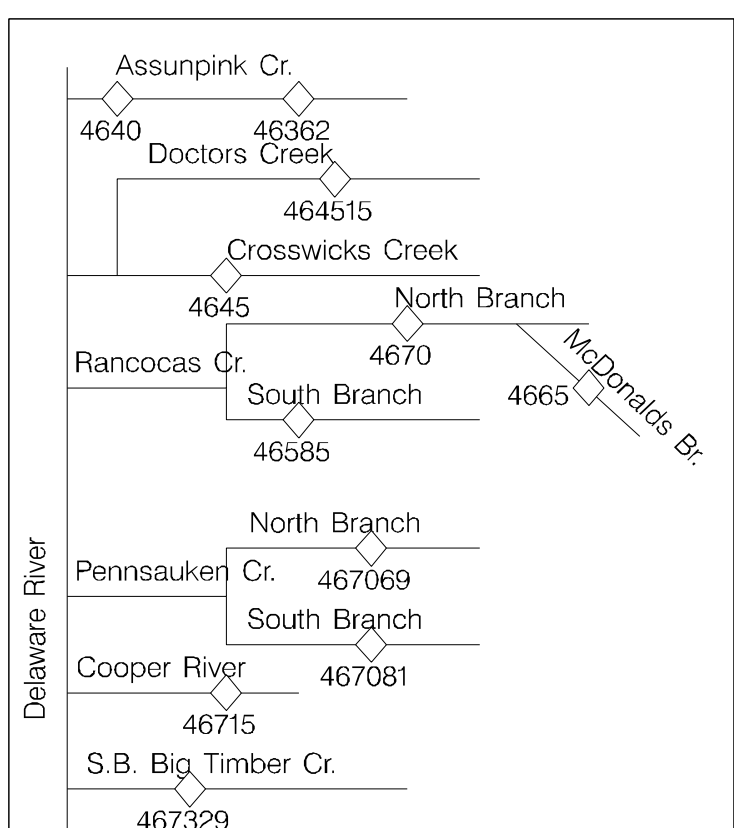

(B)

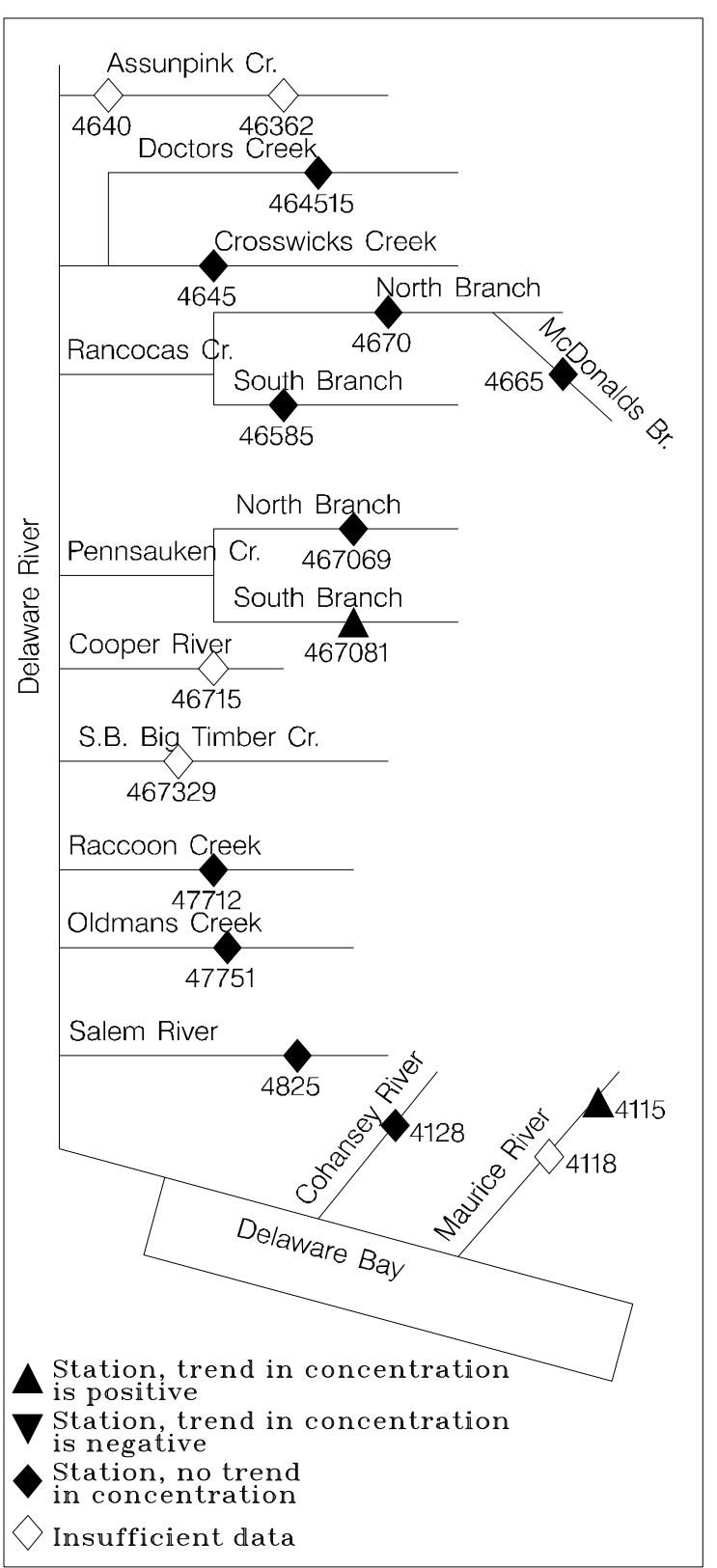

(C)

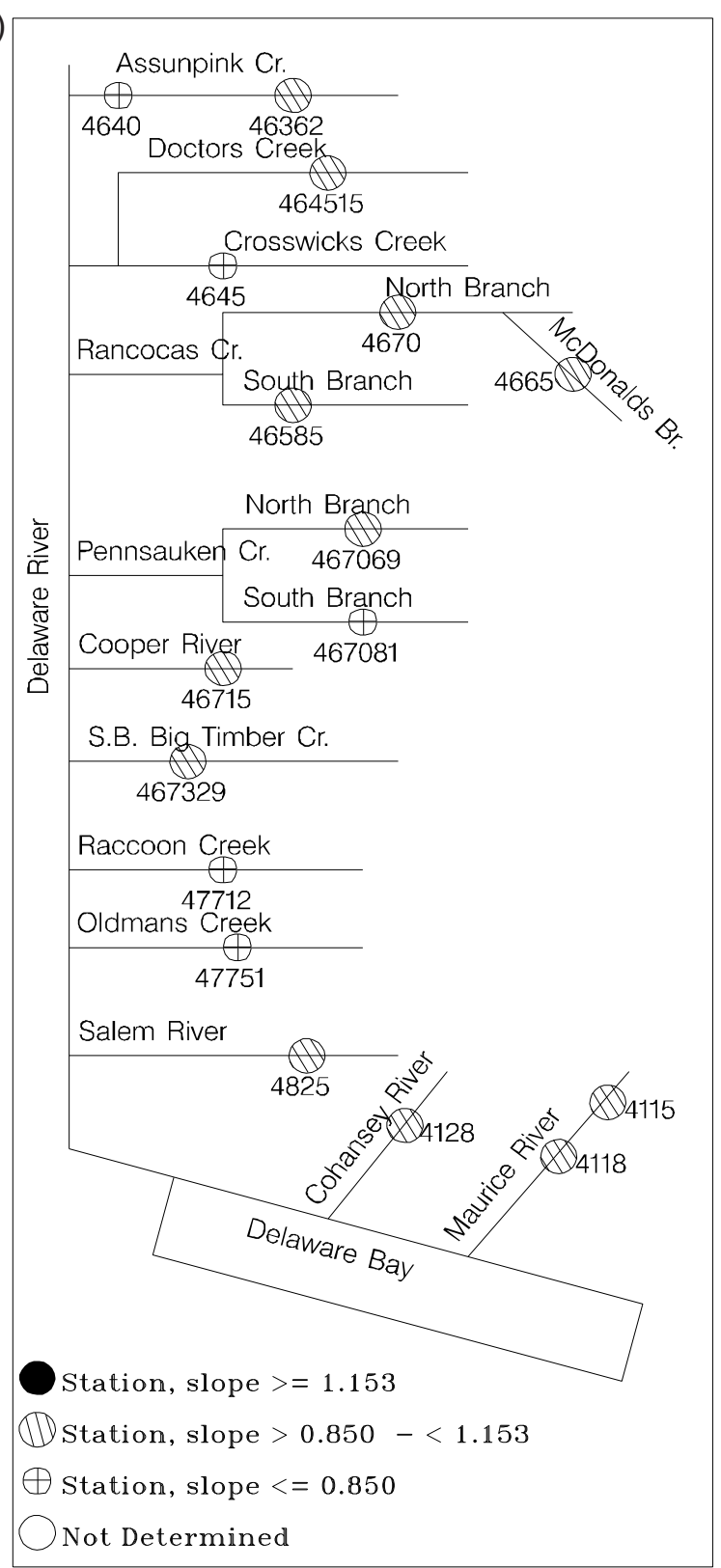

Figure 11. Trends in total hardness concentrations during $(A)$ high- and $(B)$ low-flow conditions, and $(C)$ relative slope of total hardness load to streamflow at surface-water-quality stations in the lower Delaware River and Delaware Bay Basins, N.J., water years 1976-93. 


\section{Relation of load to streamflow}

The range categories of regression slopes of hardness load to streamflow are depicted in figures 10c and 11c. The slopes range from 0.698 at station 4080 on the Manasquan River (table 5a) to 1.305 at station 4095 on the Batsto River (table 9a). The slope is in the high range only at station 4095 on the Batsto River where the contribution to instream hardness load from storm runoff is larger and less influenced by constant sources (most likely ground water) than at other sites in the study area. Slopes are in the low range at the stations on the Manasquan (4080) and Toms (4085) Rivers, the upstream station on the Great Egg Harbor River (410784), the downstream station on the Assunpink Creek (4640), and the stations on the Crosswicks (4645), South Branch of the Pennsauken (467081), Raccoon (47712), and Oldmans (47751) Creeks. At these stations, the contributions to instream hardness loads from constant sources (most likely ground water) are larger and less influenced by storm runoff than at other sites. Slopes at stations on the Assunpink Creek decrease in the downstream direction, indicating a decrease in the relative influence of contributions from storm runoff along the river.

\section{Total Organic Carbon}

The concentration of total organic carbon (TOC), an aggregate property of water, is a measure of the organic compounds in various oxidation states in surface water (Eaton and others, 1995). TOC concentrations in most surface water are small compared to dissolved inorganic solute concentrations. Although the presence of organic compounds in surface water can cause an oxygen demand as organisms decompose the compounds, a measure of TOC does not represent a measure of other organically bound elements, such as nitrogen and hydrogen, or inorganics that can contribute to the oxygen demand as measured by the biochemical or chemical oxygen demands.

The methods used to measure TOC analyze fractions of total carbon. These fractions are defined as inorganic carbon, the carbonate, bicarbonate, and dissolved carbon dioxide removed from solution by gas stripping under specified conditions; TOC, all carbon atoms covalently bonded in organic molecules; dissolved organic carbon (DOC), the fraction of TOC that passes through a $0.45 \mu \mathrm{m}$-pore-diameter filter; particulate organic carbon (POC), the fraction of TOC that is retained by a $0.45 \mu \mathrm{m}$-pore-diameter filter; volatile organic carbon (VOC), the fraction of TOC removed from an aqueous solution by gas stripping under specified conditions; and nonpurgeable organic carbon, the fraction of TOC not removed by gas stripping. In most surface water the VOC contribution to TOC is negligible. When not measured directly, TOC concentration is calculated as the sum of the DOC and POC concentrations.

\section{$\underline{\text { Relation of trends in concentration to flow conditions }}$}

TOC concentrations during high flows show no trend at the stations on the Raccoon Creek (47712) and Cohansey River (4128) (figs. 12a and 13a). The trend in TOC concentrations during low flow is negative at the one station on the Raccoon Creek (47712), indicating a decrease in the contributions from point sources and ground water over time at this station (figs. 12b and 13b). TOC concentrations during low flows show no trend at the stations on the Mullica River (409387), Hammonton Creek (409416), Batsto (4095) and Oswego (4100) Rivers, and East 
Branch of the Bass (41015) River; the upstream (410784) and downstream (41111) stations on the Great Egg Harbor River; and the stations on the Crosswicks Creek (4645), Doctors Creek (464515), South (46585) and North (4670) Branches of the Rancocas Creek, North (467069) and South (467081) Branches of the Pennsauken Creek, Oldmans (47751) Creek, and Salem (4825) and Cohansey (4128) Rivers.

\section{Relation of load to streamflow}

The range categories of regression slopes of TOC load to streamflow are depicted in figures $12 \mathrm{c}$ and $13 \mathrm{c}$. The slopes range from 0.839 at station 4825 on the Salem River (table 29a) to 1.788 at the downstream station on the Great Egg Harbor River (41111) (table 15a). Slopes are in the high range at the station on the East Branch of the Bass River (41015), the downstream stations on the Great Egg Harbor River (4110 and 41111), the one station on the McDonalds Branch (4665), and the upstream station on the Maurice River (4115). At these sites, the contributions to instream TOC loads from storm runoff (most likely water displaced from wetlands) are larger and less influenced by constant sources than at other sites in the study area. Slopes are in the low range at the stations on the Hammonton Creek (409416) and West Branch of the Wading River (409815); the upstream station on the Assunpink Creek (46362); and the stations on the Doctors (464515), North Branch of the Pennsauken (467069), and Oldmans (47751) Creeks and the Salem River (4825). At these sites, however, the contributions to instream TOC loads from constant sources probably are relatively insignificant because the loadto-streamflow slopes are large (greater than 0.8). Storm runoff most likely is the dominant contributor of TOC in the study area because the load-to-streamflow slopes at all stations are large.

\section{Suspended Sediment}

Suspended sediment, an aggregate property of water, is the portion of total solids that is retained by a filter under specified conditions; its concentration is determined by the weight of the dry residue remaining after evaporation of the volatile portion of a sample aliquot by heating to $105^{\circ} \mathrm{C}$ (Eaton and others, 1995). Large concentrations of suspended sediments in surface water could inhibit light penetration to bottom-dwelling macrophytes and create esthetically unsatisfactory conditions for such purposes as swimming. Some metals, nutrients, and organic compounds can associate with the surface of the suspended sediment and be transported with the suspended sediment in surface water. Suspended sediment concentration is the velocity-weighted concentration of suspended sediment in the sampled zone (from the water surface to a constant approximately 0.3 feet above the bed) (Bauersfeld and others, 1994). Generally, the primary source of suspended sediment in a stream is from erosion, streambed scour and overland runoff during storm events.

\section{$\underline{\text { Relation of trends in concentration to flow conditions }}$}

Suspended sediment concentrations show no trend at the stations on the Toms River (4085) and McDonalds Branch (4665) during high (figs. 14a and 15a) and low (figs. 14b and 15b) flows. Sufficient data are not available for all other stations to determine trends in concentrations 

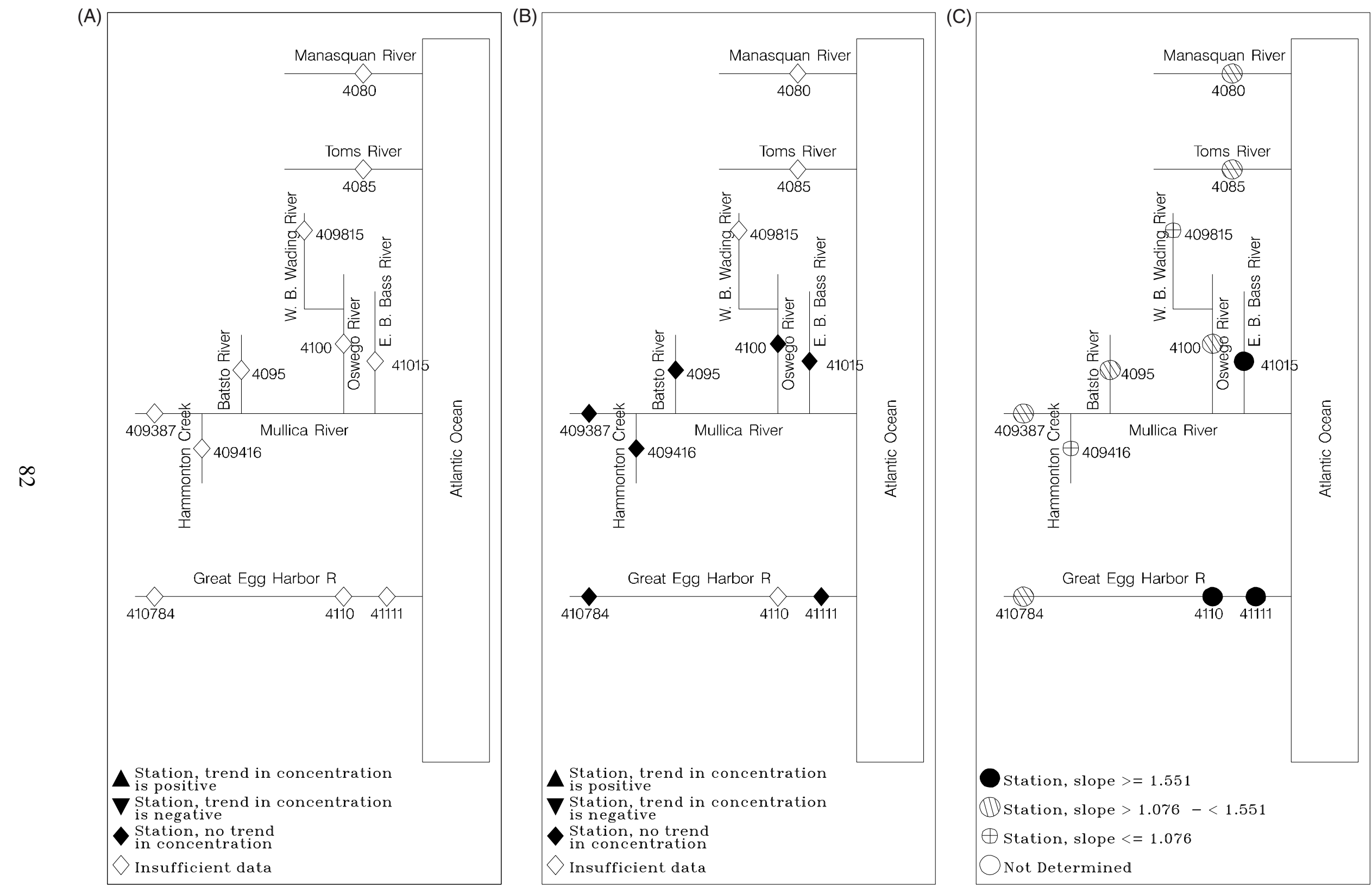

Figure 12. Trends in total organic carbon concentrations during (A) high- and (B) low-flow conditions, and (C) relative slope of total organic carbon load to streamflow at surface-water-quality stations in the Atlantic Coastal Basins, N.J., water years 1976-93. 
(A)

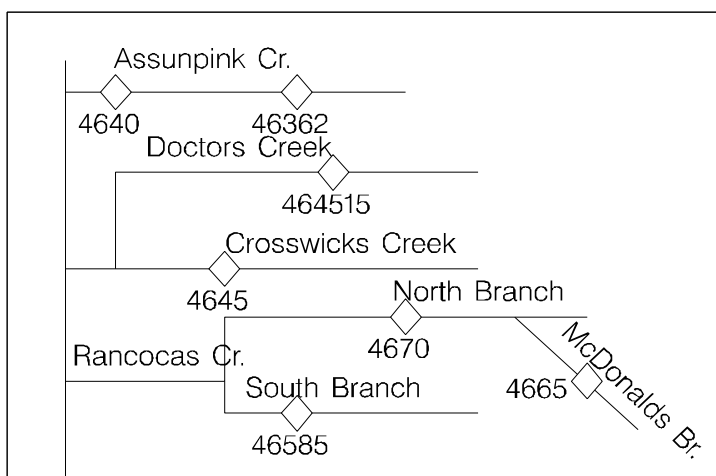

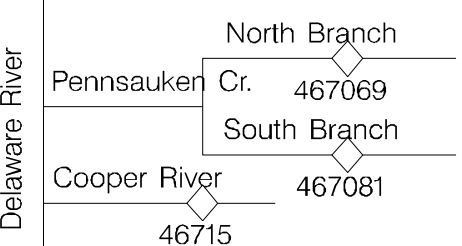

S.B. Big Timber $\mathrm{Cr}$.
(B)

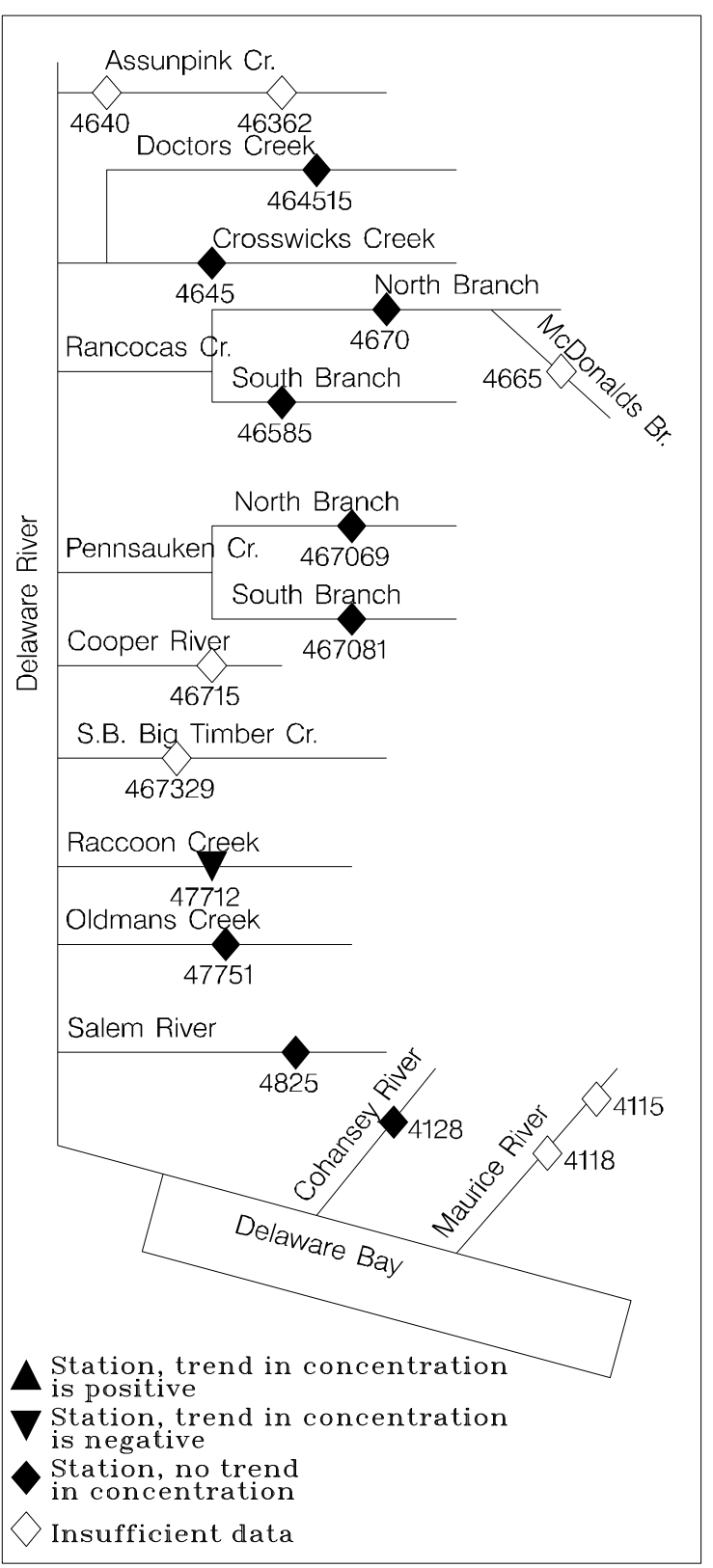

(C)

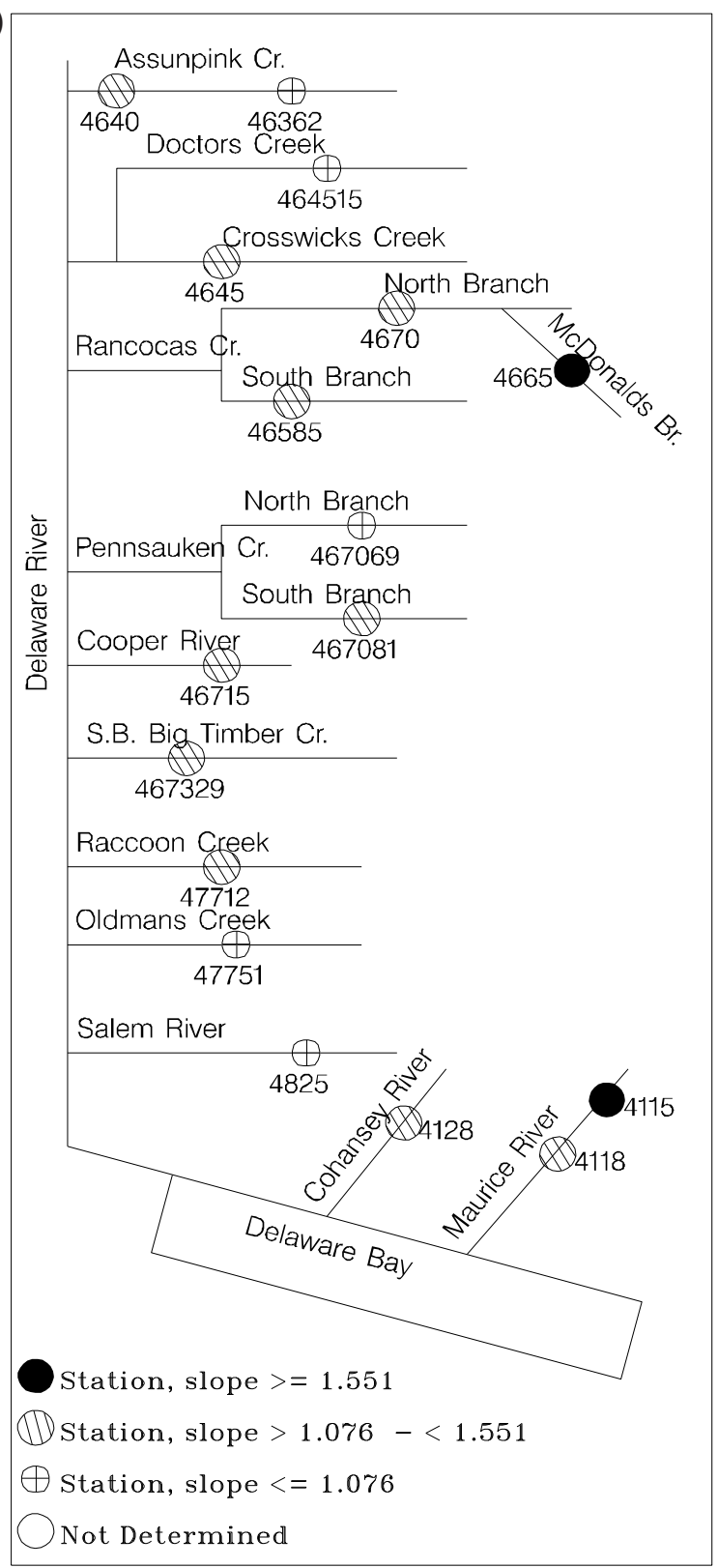

Figure 13. Trends in total organic carbon concentrations during (A) high- and (B) low-flow conditions, and (C) relative slope of total organic carbon load to streamflow at surface-water-quality stations in the lower Delaware River and Delaware Bay Basins, N.J., water years 1976-93. 

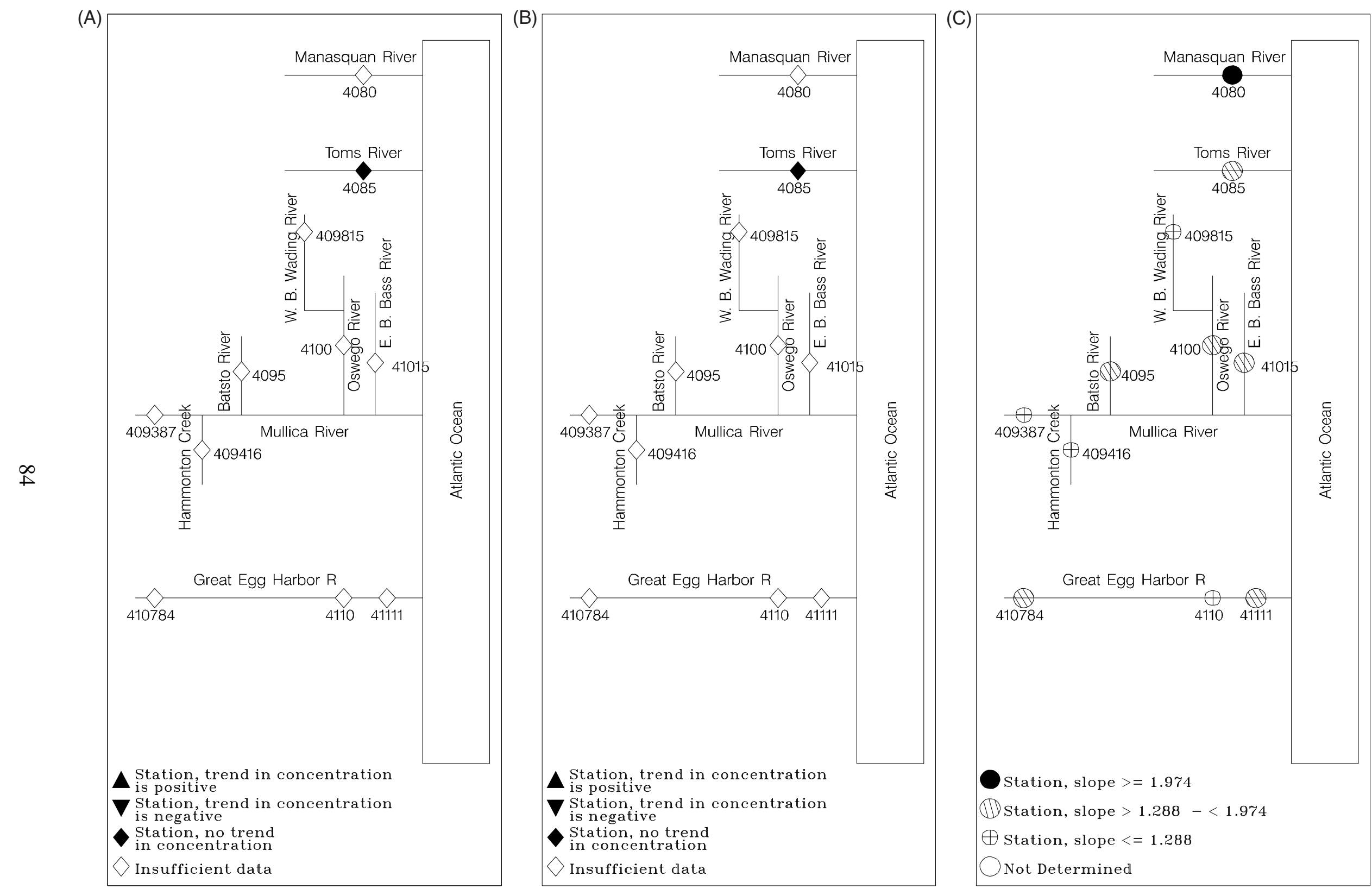

Figure 14. Trends in suspended sediment concentrations during (A) high- and (B) low-flow conditions, and (C) relative slope of suspended sediment load to streamflow at surface-water-quality stations in the Atlantic Coastal Basins, N.J., water years 1976-93. 
(A)
(B)

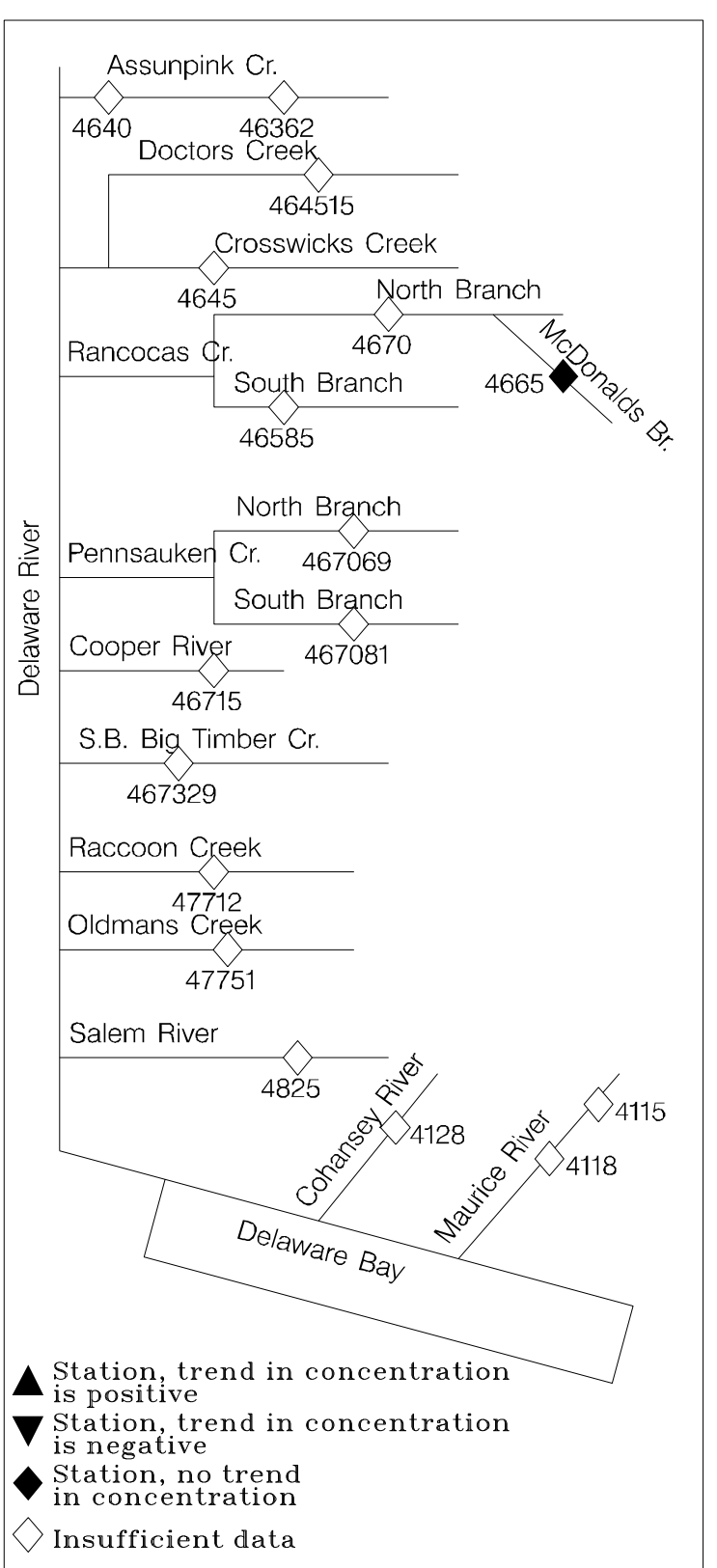

(C)

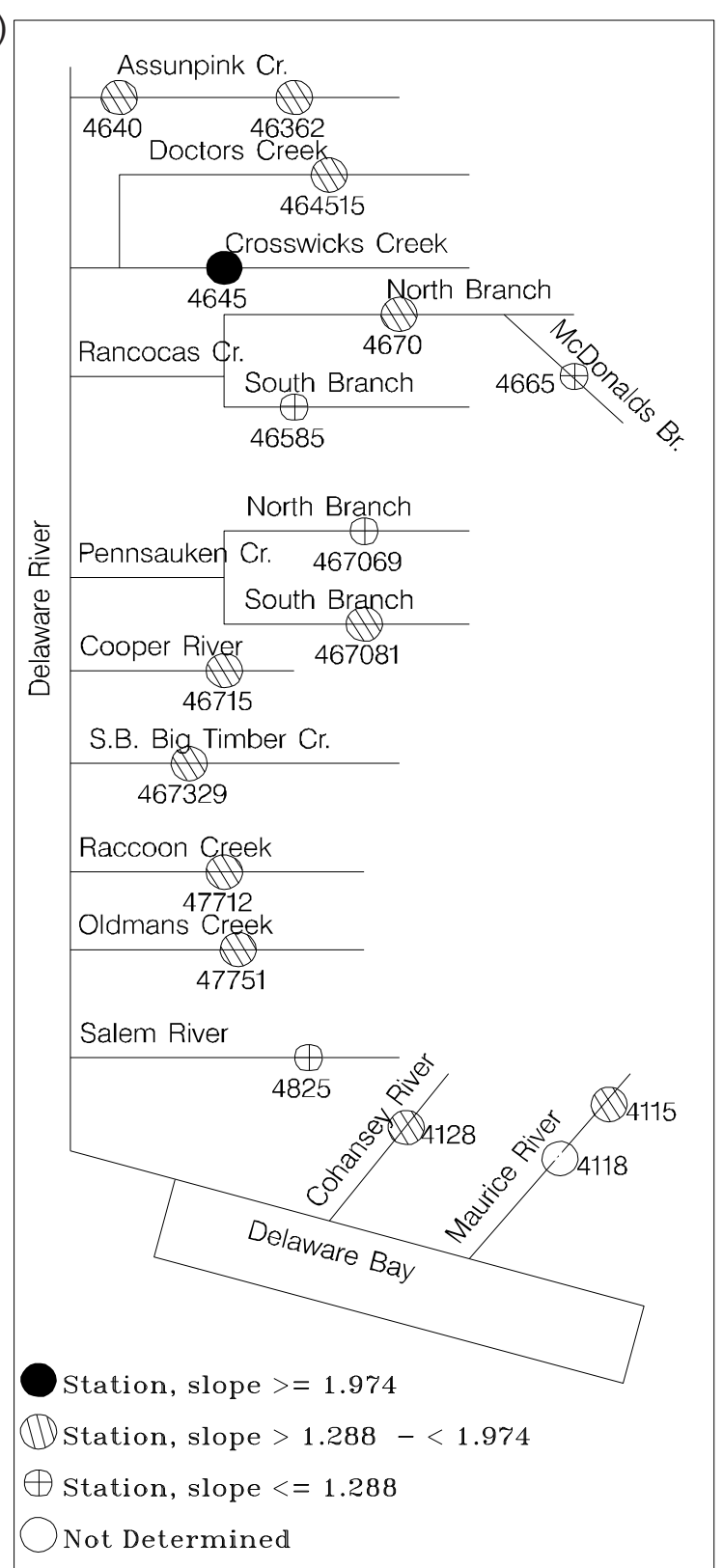

Figure 15. Trends in suspended sediment concentrations during (A) high- and (B) low-flow conditions, and (C) relative slope of suspended sediment load to streamflow at surface-water-quality stations in the lower Delaware River and Delaware Bay Basins, N.J., water years 1976-93. 
of suspended sediment to streamflow. Suspended sediment concentrations are generally small in Coastal Plain streams. Sampling frequency of this network is random and, therefore, is not sensitive to the dynamics of suspended sediments in Coastal Plain streams.

\section{$\underline{\text { Relation of load to streamflow }}$}

The range categories of regression slopes of suspended sediment load to streamflow are depicted in figures $14 \mathrm{c}$ and 15c. The slopes range from 0.945 at station 409387 on the Mullica River (table 7a) to 2.317 at station 4080 on the Manasquan River (table 5a). Insufficient data are available to determine the slope at the downstream station on the Maurice River (4118). Load-tostreamflow slopes are larger for suspended sediments than for any other constituent at all stations. During high flows, the stream velocity can become sufficient to scour the streambed, thereby, making the streambed an additional source of measured instream load; hence, the load-tostreamflow slopes are higher than those of other constituents. The influence of streamflow velocity on the magnitude of the load-to-streamflow slope ideally is considered when evaluating the influence of point sources and storm runoff.

Slopes are in the high range at the stations on the Manasquan River (4080) and Crosswicks Creek (4645) where the contributions to instream suspended sediment loads from storm runoff are larger and less influenced by point sources and ground water than at other sites in the study area. Slopes are in the low range at the stations on the Mullica River (409387), Hammonton Creek (409416), West Branch of the Wading River (409815), Great Egg Harbor River (4110), South Branch of the Rancocas Creek (46585), McDonalds Branch (4665), North Branch of the Pennsauken Creek (467069), and Salem River (4825). At these sites, however, the contributions to suspended sediment loads from constant sources probably are relatively insignificant because the load-to-streamflow slopes are large (greater than 0.8). Storm runoff most likely is the dominant contributor of suspended sediment in the study area because the loadto-streamflow slopes at all stations are large.

\section{Dissolved Solids}

Dissolved solids, an aggregate property of water, is that part of total solids that passes through a filter of $0.45-\mu \mathrm{m}$ (or smaller) nominal pore size under specified conditions; its concentration is determined by the weight of the dry residue remaining after evaporation of the volatile portion of a sample aliquot by heating to $180{ }^{\circ} \mathrm{C}$, the residue-upon-evaporation method (Eaton and others, 1995). All carbonates and bicarbonates will break down when heated, but organic matter will be only partially volatilized and not completely removed. Water with large concentrations of dissolved solids generally has an inferior palatability. Salts used for deicing highways can be carried to surface water by storm runoff and melting snow and contribute to the dissolved solids load. The dissolved solids concentration can be compared to the computed ion balance when checking a water analysis. 


\section{$\underline{\text { Relation of trends in concentration to flow conditions }}$}

The trend in dissolved solids concentration during high flows is positive at the one station on the Raccoon Creek (47712), indicating an increase in the contribution from storm runoff over time at this station (figs. 16a and 17a). The trend in dissolved solids concentration during high flows is negative at the upstream station on the Maurice River (4115), indicating a decrease in the contribution from storm runoff over time at this station. Dissolved solids concentrations during high flows show no trends at the stations on the Toms River (4085), McDonalds Branch (4665), and Cohansey River (4128). Concentrations of dissolved solids during low flows show no trend at the stations on the Toms River (4085), Hammonton Creek (409416), and Batsto (4095), West Branch of the Wading (409815), Oswego (4100), and East Branch of the Bass (41015) Rivers; the downstream station on the Great Egg Harbor River (41111); the stations on the Crosswicks (4645) and Doctors (464515) Creeks, McDonalds Branch (4665), South (46585) and North (4670) Branches of the Rancocas Creek, North (467069) and South (467081) Branches of the Pennsauken Creek, Oldmans Creek (47751), and Salem (4825) and Cohansey (4128) Rivers; and the upstream station on the Maurice River (4115) (figs. 16b and 17b).

\section{Relation of load to streamflow}

The range categories of regression slopes of dissolved solids load to streamflow are depicted in figures $16 \mathrm{c}$ and $17 \mathrm{c}$. The slopes range from 0.739 at the downstream station on the Assunpink Creek (4640) (table 17a) to 1.345 at station 4665 on the McDonalds Branch (table 21a). Slopes are in the high range at the stations on the Batsto River (4095) and McDonalds Branch (4665), indicating that the contributions to instream dissolved solids loads from storm runoff are larger and less influenced by constant sources at these stations than at other sites in the study area. Slopes are in the low range at the one station on the Hammonton Creek (409416); the downstream station on the Assunpink Creek (4640); the stations on the Crosswicks (4645), South Branch of the Pennsauken (467081), and Raccoon (47712) Creeks; and the station on the Cohansey River (4128). At these sites, the contributions to instream dissolved solids loads from constant sources are larger and less influenced by storm runoff than at other sites in the study area. Slopes at stations on the Assunpink Creek decrease in the downstream direction, indicating a decrease in the relative influence of contributions from storm runoff along the river.

\section{Dissolved Sodium}

Sodium is present in most surface water. The ratio of sodium to total cations is important in agriculture and human pathology. Sodium tends to remain in solution, when dissolved from rocks by weathering, and not form precipitates that can maintain low sodium concentrations. Sodium is retained by adsorption on mineral surfaces, especially by minerals with high cationexchange capacities, such as clays. Cation exchange processes in freshwater systems tend to extract divalent ions from solution and replace then with monovalent ions, especially sodium (Hem, 1985). Sodium salts used for deicing highways can be carried to surface water with storm runoff and melting snow. The reuse of water for irrigation commonly leaves a residual that is much greater in sodium concentration than was the original water. 

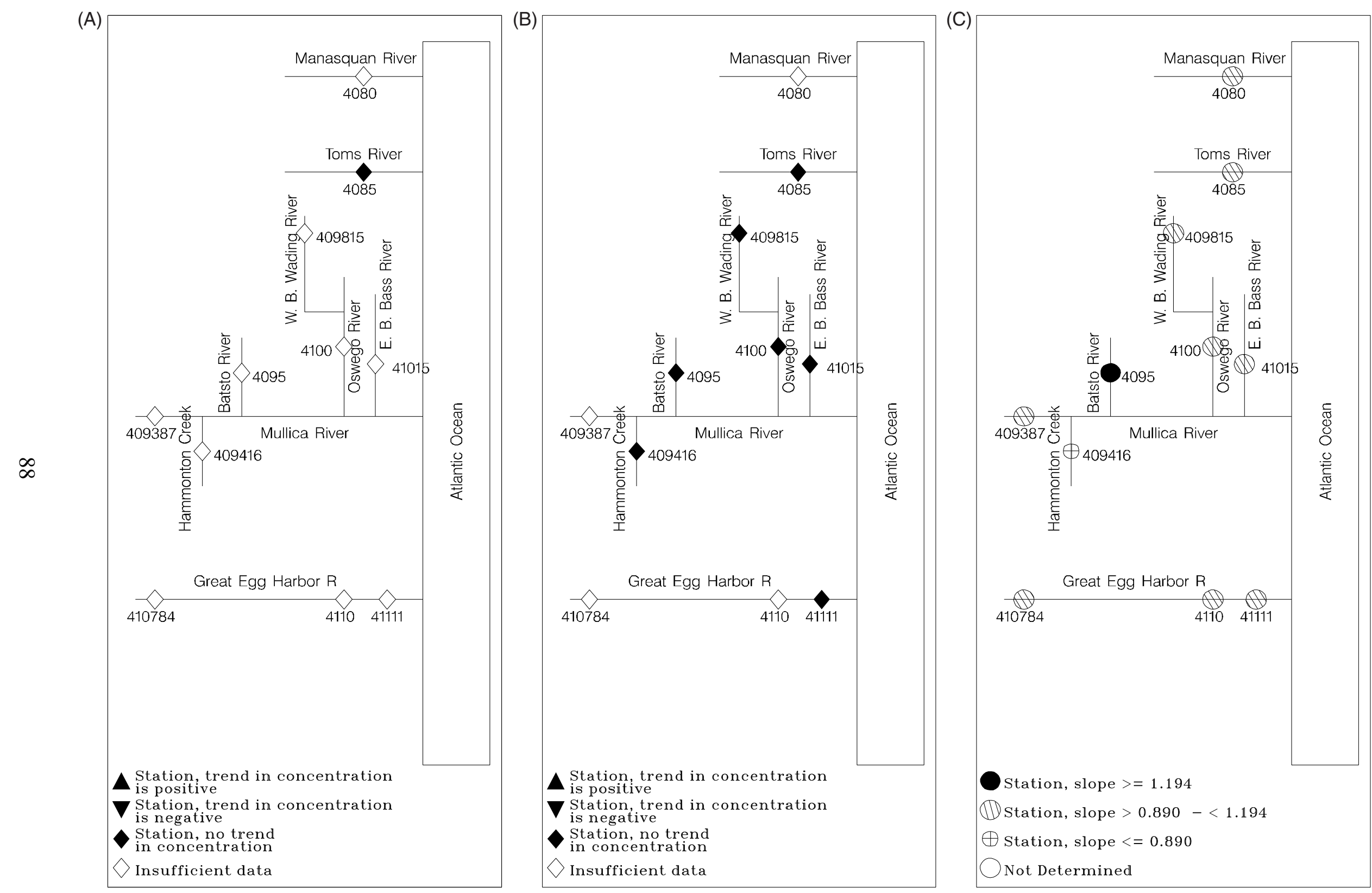

Figure 16. Trends in dissolved solids concentrations during (A) high- and (B) low-flow conditions, and (C) relative slope of dissolved solids load to streamflow at surface-water-quality stations in the Atlantic Coastal Basins, N.J., water years 1976-93. 

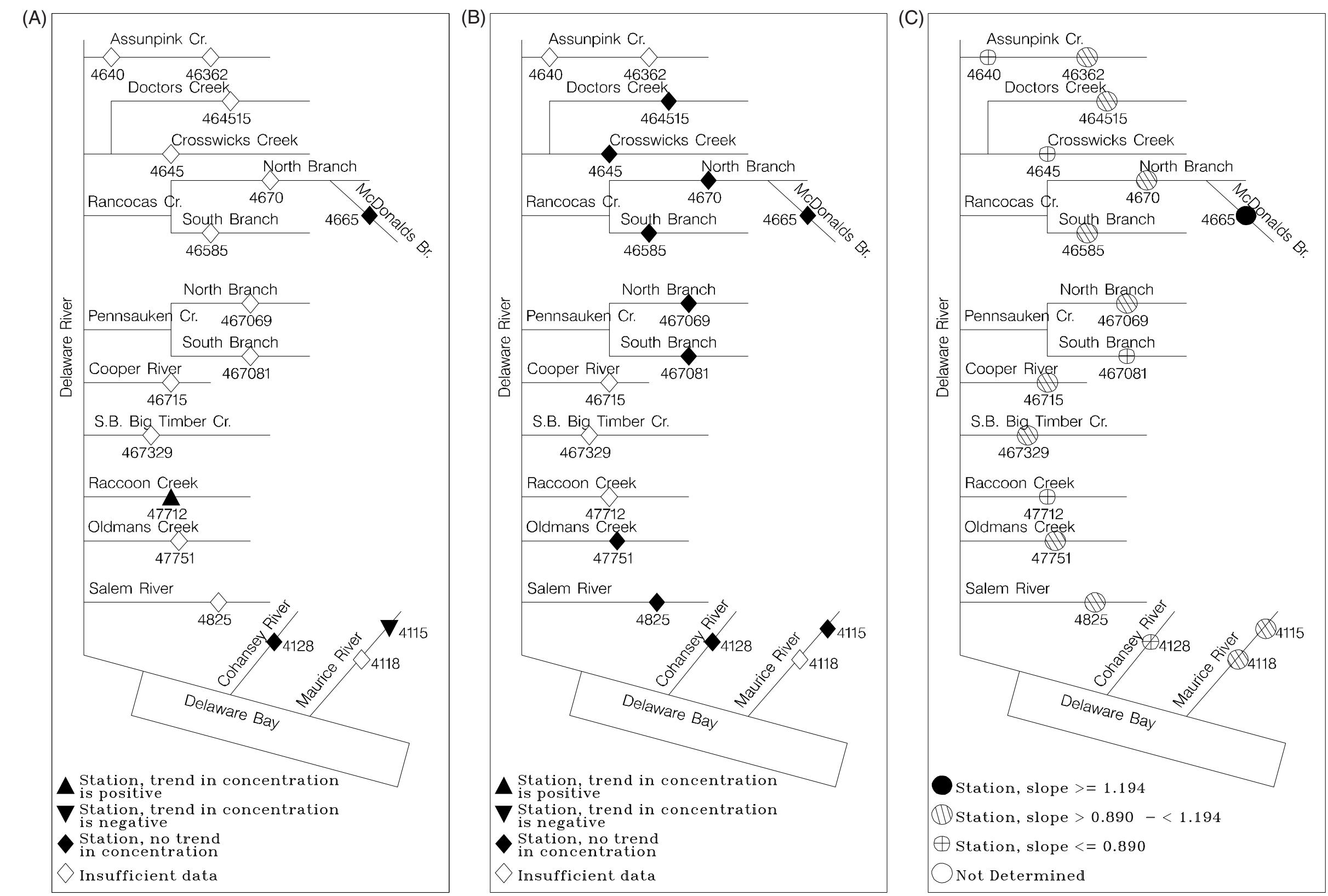

Figure 17. Trends in dissolved solids concentrations during (A) high- and (B) low-flow conditions, and (C) relative slope of dissolved solids load to streamflow at surface-water-quality stations in the lower Delaware River and Delaware Bay Basins, N.J., water years 1976-93. 


\section{$\underline{\text { Relation of trends in concentration to flow conditions }}$}

Trends in sodium concentrations during high flows are shown in figures 18a and 19a. A positive trend at the one station on Raccoon Creek (47712) indicates an increase in the contributions from storm runoff over time. Sodium concentrations during high flows show no trends at the stations on the Toms (4085) and Cohansey (4128) Rivers, and the upstream station on the Maurice River (4115). Trends in sodium concentrations during low flows are positive at the stations on the Toms River (4085), West Branch Wading River (409815), Doctors Creek (464515), North Branch of the Rancocas Creek (4670), Oldmans Creek (47751), and Salem River (4825) (figs. 18b and 19b). Contributions from point sources and ground water increased over

time at these sites. Trends in sodium concentrations during low flows are negative at the downstream stations on the Great Egg Harbor River (4110 and 41111), the station on the North Branch of the Pennsauken Creek (467069), and the upstream station on the Maurice River (4115). The contributions from point sources and ground water decreased over time at these sites. Sodium concentrations during low flows show no trends at stations on the Mullica River (409387), Hammonton Creek (409416), Batsto River (4095), Oswego River (4100), and East Branch of the Bass River (41015), Crosswicks Creek (4645), McDonalds Branch (4665), South Branches of the Rancocas (46585) and Pennsauken Creeks (467081), Raccoon Creek (47712), and Cohansey River (4128).

\section{$\underline{\text { Relation of load to streamflow }}$}

The range categories of regression slopes of dissolved sodium load to streamflow are depicted in figures 18c and 19c. The slopes range from 0.609 at station 409416 on the Hammonton Creek (table 8a) to 1.078 at station 41015 on the East Branch of the Bass River (table 12a). Slopes are in the high range at the stations on the Mullica (409387), Batsto (4095), and East Branch of the Bass (41015) Rivers; the upstream station on the Assunpink Creek (46362); and the stations on the Cooper River (46715) and Oldmans Creek (47751). At these stations, the contributions to instream sodium loads from storm runoff are larger and less influenced by point sources and (or) ground water than at other sites in the study area. Slopes are in the low range at the one station on the Hammonton Creek (409416); the downstream station on the Assunpink Creek (4640); and the stations on the Crosswicks Creek (4645), South Branch of the Pennsauken Creek (467081), and Cohansey River (4128). At these stations, the contributions to instream sodium loads from point sources and (or) ground water are larger and less influenced by storm runoff than at other sites in the study area. Slopes at stations on the Assunpink Creek decrease in the downstream direction, indicating a decrease in the relative influence of contributions from storm runoff along the river.

\section{Dissolved Chloride}

Chloride is present in all surface water, but usually in low $(<10 \mathrm{mg} / \mathrm{L})$ concentrations. Chloride ions do not significantly enter into oxidation or reduction reactions, form no important solute complexes with other ions unless the chloride concentration is extremely high, do not form salts of low solubility, are not significantly adsorbed on mineral surfaces, and play few vital 
biochemical roles (Hem, 1985). Conservative constituents such as chloride move through a stream system mainly by physical processes (water inputs and withdrawals). Chloride is present in various rock types in concentrations lower than that of any of the other major constituents of ambient water. In most streams, chloride concentrations are smaller than those of sulfate or bicarbonate. Exceptions occur where streams receive inflows of ground water or industrial wastewater containing large concentrations of chloride, or are affected by oceanic tides. Chloride salts used for deicing highways can be carried to surface water by storm runoff and melting snow.

\section{$\underline{\text { Relation of trends in concentration to flow conditions }}$}

The trends in chloride concentrations during high flows are positive at the stations on the Toms River (4085) and Raccoon Creek (47712), indicating an increase in the contribution from storm runoff over time at these sites (figs. 20a and 21a). Chloride concentrations during high flows show no trends at the stations on the McDonalds Branch (4665) and Cohansey River (4128) and the upstream station on the Maurice River (4115). The trends in chloride concentrations during low flows are positive at the stations on the Toms River (4085), West Branch of the Wading River (409815), Crosswicks Creek (46450), South (46585) and North (4670) Branches of the Rancocas Creek, South Branch of the Pennsauken Creek (467081), Raccoon Creek (47712), and Salem River (4825); and the upstream station on the Maurice River (4115) (figs. 20b and 21b). Contributions from point sources and ground water increase over time at these sites. Trends in chloride concentrations during low flows are negative at the downstream stations on the Great Egg Harbor River (4110 and 41111) and the one station on the Cohansey River (4128). Contributions from constant sources (most likely ground water) decrease over time at these sites. Chloride concentrations during low flows show no trend at the stations on Hammonton Creek (409416), Batsto River (4095), East Branch of the Bass River (41015), Doctors Creek (464515), McDonalds Branch (4665), North Branch of the Pennsauken Creek (467069), and Oldmans Creek (47751).

\section{Relation of load to streamflow}

The range categories of regression slopes of chloride load to streamflow are depicted in figures 20c and 21c. The slopes range from 0.635 at the downstream station on the Assunpink Creek (4640) (table 17a) to 1.128 at station 4095 on the Batsto River (table 9a). The slopes are in the high range at the stations on the Mullica (409387) and Batsto (4095) Rivers, and East Branch of the Bass River (41015). At these stations, the contributions to instream chloride loads from storm runoff are larger and less influenced by constant sources (most likely ground water) than at other sites in the study area. The slopes are in the low range at the downstream station on the Assunpink Creek (4640) and the one station on the Cohansey River (4128). At these sites, the contributions to instream chloride loads from point sources and (or) ground water are larger and less influenced by storm runoff than at other sites in the study area. Slopes at stations on the Assunpink Creek decrease in the downstream direction, indicating a decrease in the relative influence of contributions from storm runoff along the river. 

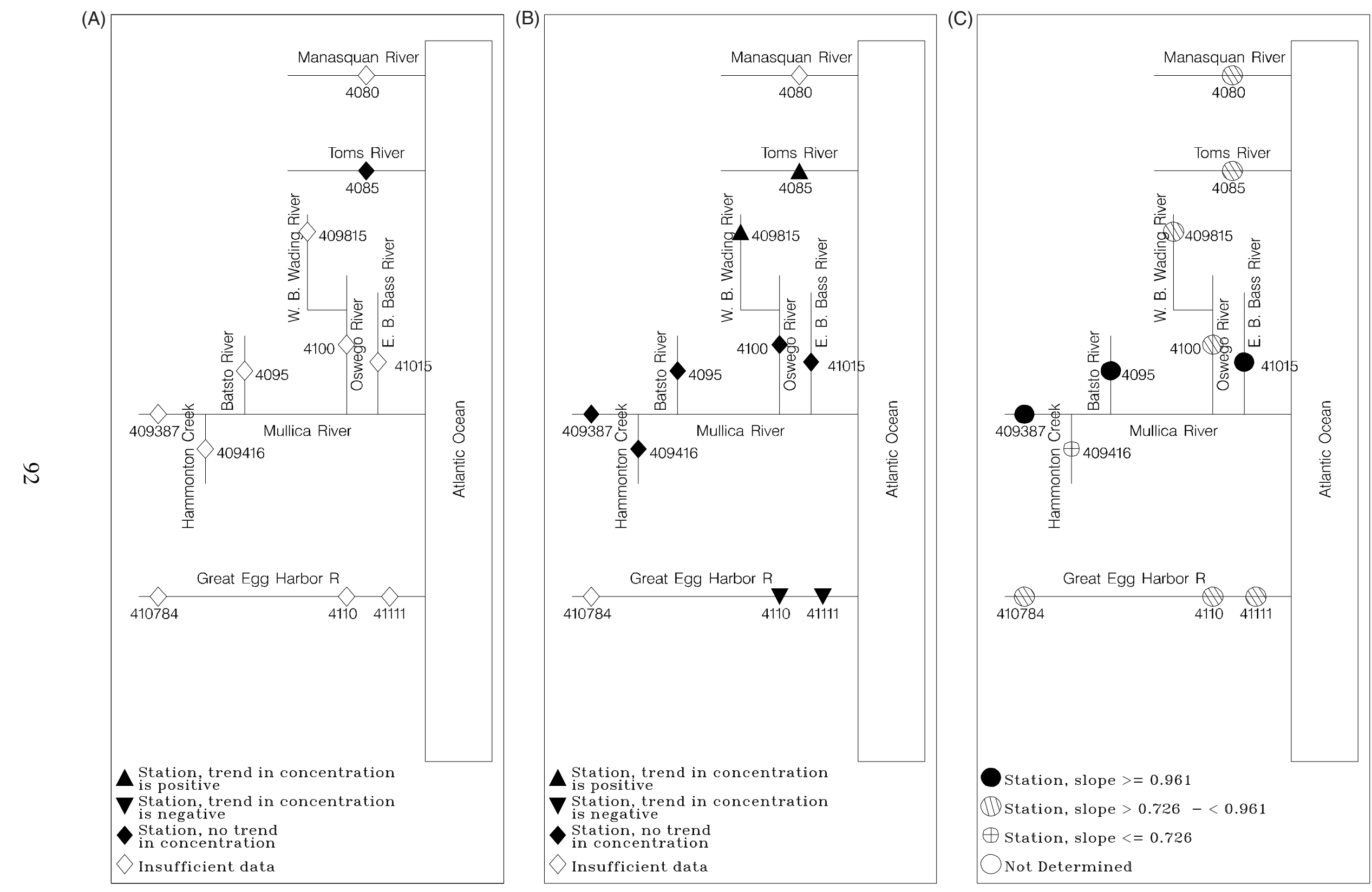

Figure 18. Trends in dissolved sodium concentrations during (A) high- and (B) low-flow conditions, and (C) relative slope of dissolved sodium load to streamflow at surface-water-quality stations in the Atlantic Coastal Basins, N.J., water years 1976-93. 

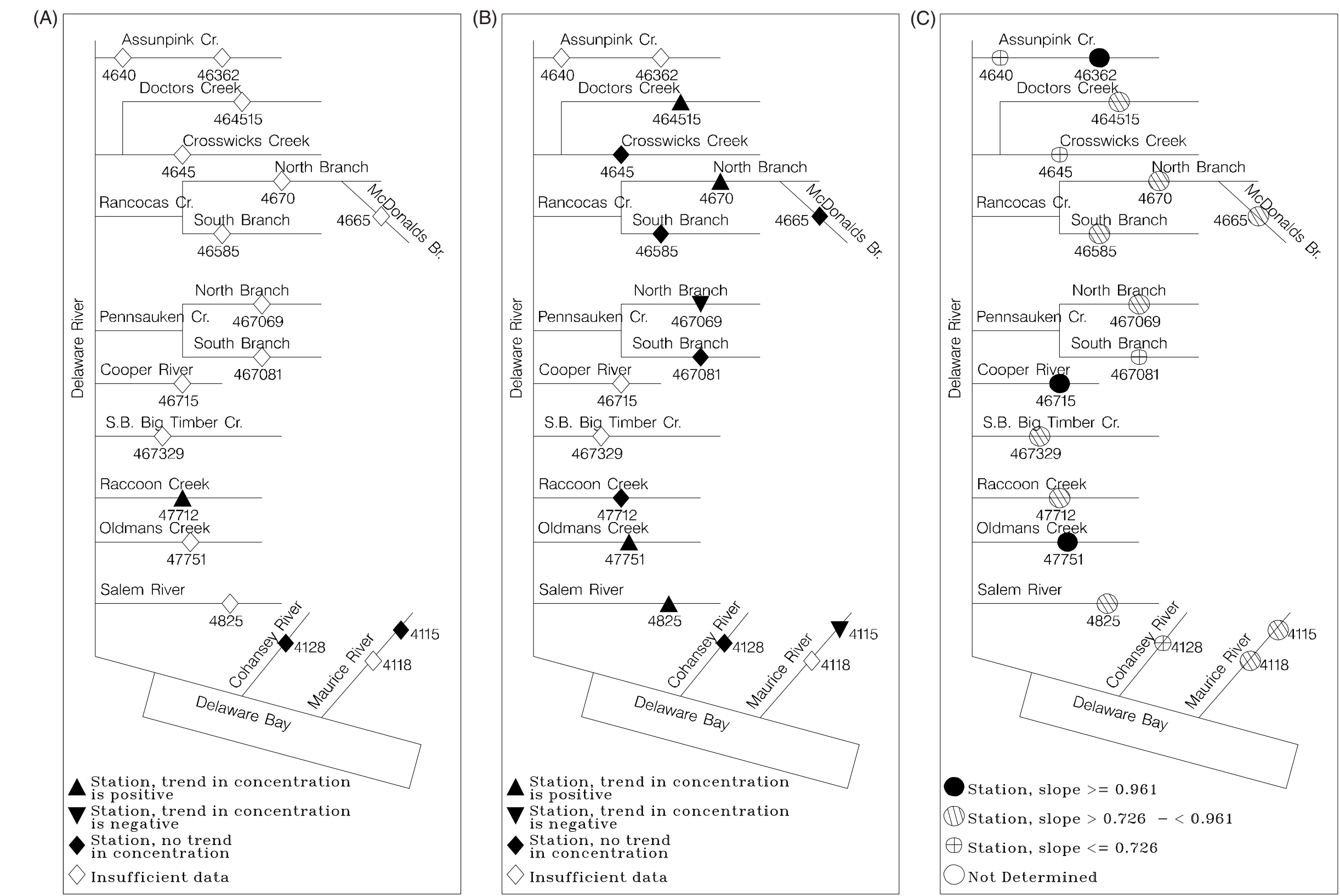

Figure 19. Trends in dissolved sodium concentrations during (A) high- and (B) low-flow conditions, and (C) relative slope of dissolved sodium load to streamflow at surface-water-quality stations in the lower Delaware River and Delaware Bay Basins, N.J., water years 1976-93. 

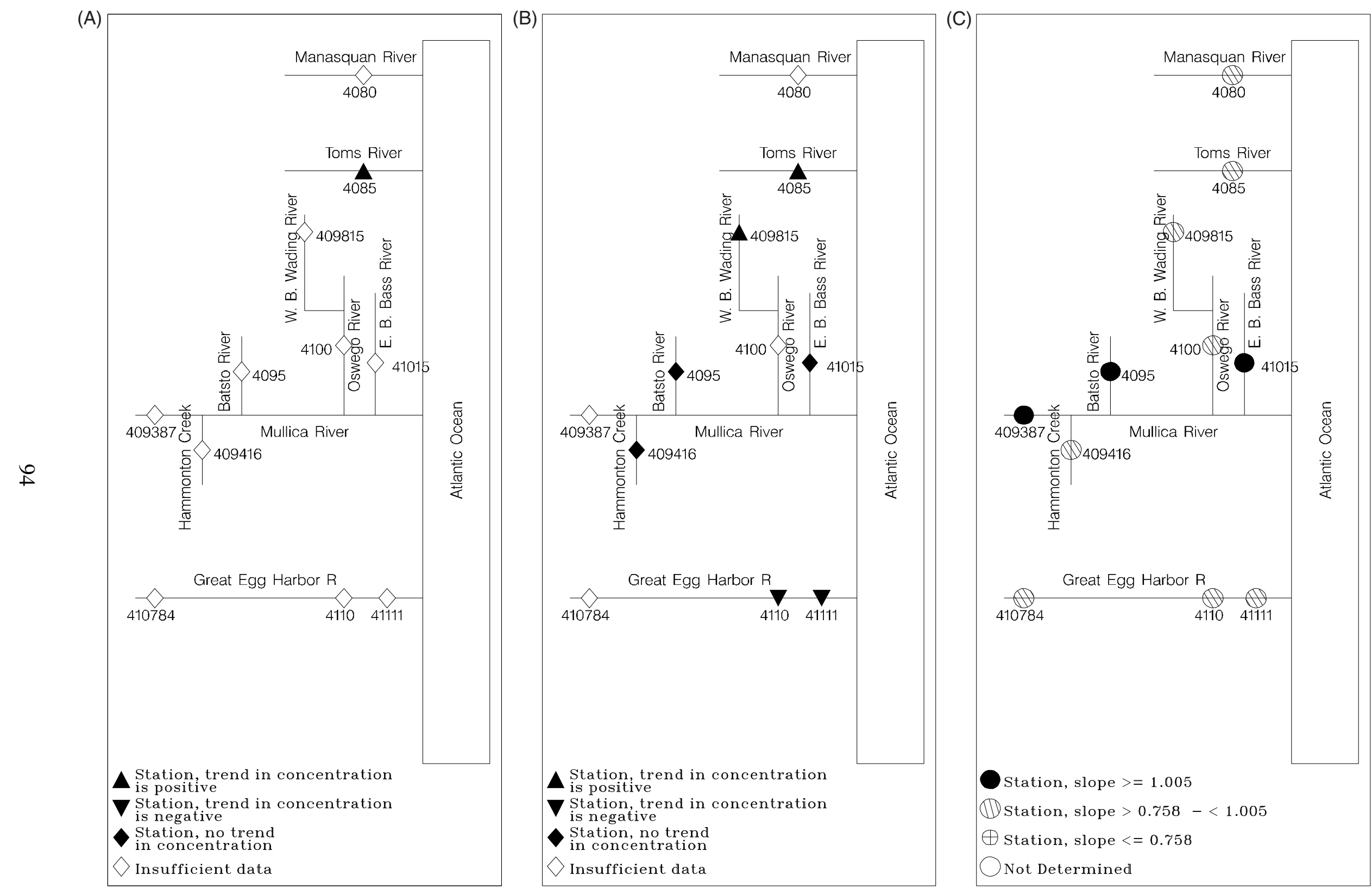

Figure 20. Trends in dissolved chloride concentrations during (A) high- and (B) low-flow conditions, and (C) relative slope of dissolved chloride load to streamflow at surface-water-quality stations in the Atlantic Coastal Basins, N.J., water years 1976-93. 

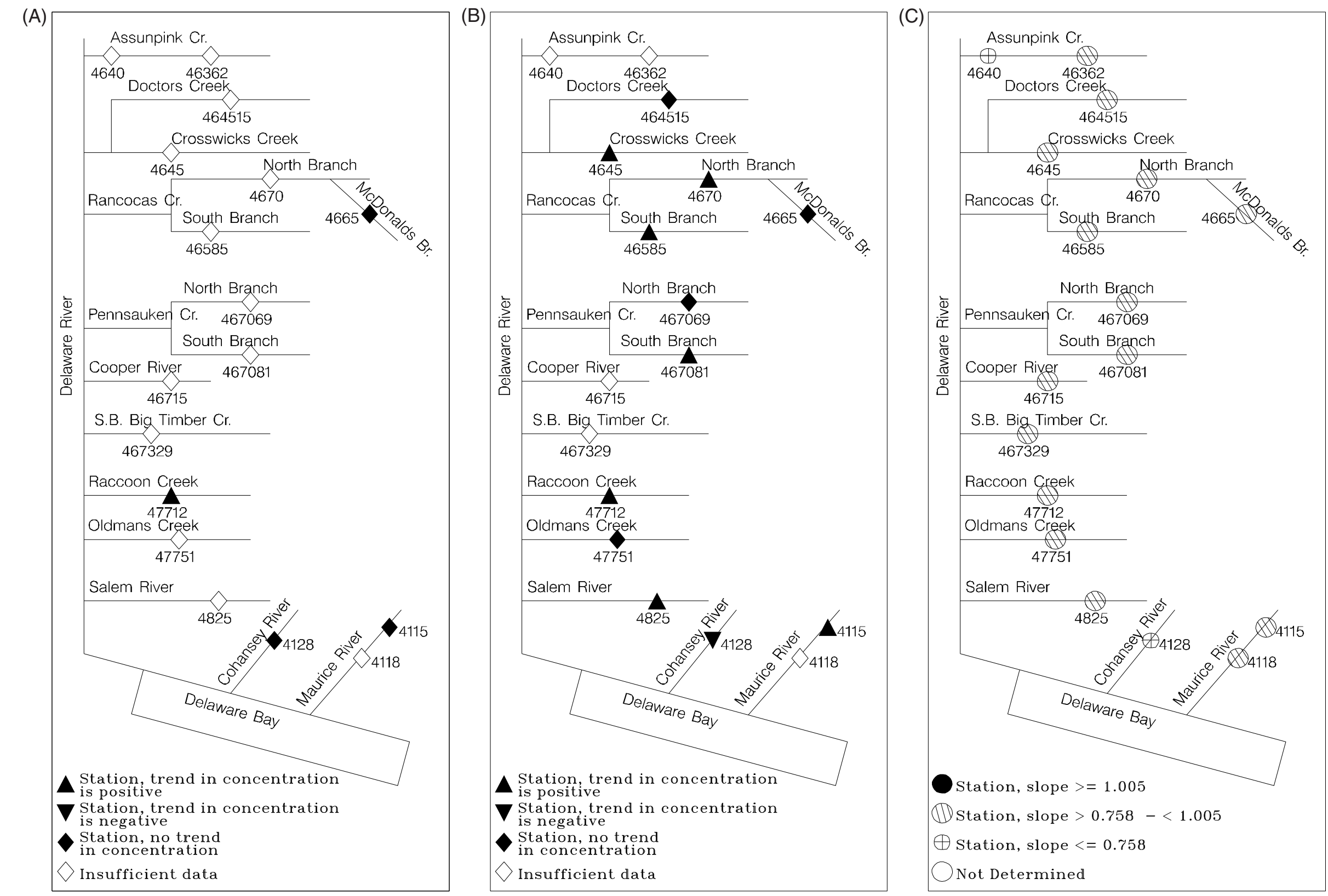

Figure 21. Trends in dissolved chloride concentrations during (A) high- and (B) low-flow conditions, and (C) relative slope of dissolved chloride load to streamflow at surface-water-quality stations in the lower Delaware River and Delaware Bay Basins, N.J., water years 1976-93. 


\section{Dissolved Oxygen}

Dissolved oxygen (DO) concentrations in surface water depend on the physical, chemical, and biochemical activities occurring in the water body and are a function of water temperature, atmospheric pressure, and concentrations of other solutes. The higher forms of aquatic life require oxygen for survival, and the measurement of DO is used widely to evaluate the biochemistry of surface water (Hem, 1985). Photosynthesis and water turbulence are important mechanisms that replenish DO consumed by respiration and decomposition of organic matter. Oxygen supersaturation can occur in slow moving systems in winter and when photosynthesizing biota are abundant during the summer. The presence of organic compounds and abundant algae in surface water can cause oxygen demand. Positive trends and steep slopes of load to streamflow can indicate improved water quality.

\section{$\underline{\text { Relation of trends in concentration to flow conditions }}$}

Dissolved oxygen concentrations during high flows show no trend at the one station on the Toms River (4085); the downstream station on the Assunpink Creek (4640); the stations on the McDonalds Branch (4665), Cooper River (46715), Raccoon Creek (47712), and Cohansey River (4128); and the upstream station on the Maurice River (4115) (figs. 22a and 23a). Trends in dissolved oxygen concentrations during low flows are positive at the stations on the Manasquan River (4080) and North Branch of the Pennsauken Creek (467069) (figs. 23b and 24b). Dissolved oxygen concentrations during low flows show no trend at all stations on the Toms (4085) and Mullica (409387) Rivers, Hammonton Creek (409416), Batsto River (4095), West Branch of the Wading River (409815), Oswego River (4100), East Branch of the Bass River (41015), Great Egg Harbor River (410784, 4110, and 41111), Crosswicks (4645) and Doctors (464515) Creeks, McDonalds Branch (4665), South (46585) and North (4670) Branches of the Rancocas Creek, South Branch of the Pennsauken Creek (467081), Raccoon (47712) and Oldmans (47751) Creeks, and Salem (4825), Cohansey (4128), and Maurice (4115 and 4118) Rivers (figs. 22b and 23b).

\section{$\underline{\text { Relation of load to streamflow }}$}

The range categories of regression slopes of dissolved oxygen load to streamflow are depicted in figures $22 \mathrm{c}$ and $23 \mathrm{c}$. The range of slopes is narrow, ranging from 0.986 at the upstream station on the Maurice River (4115) (table 31a) to 1.342 at station 4665 on the McDonalds Branch (table 21a), the only station with a slope in the high range. The slopes are in the low range at the stations on the Manasquan (4080), Toms (4085), Mullica (409387), Batsto (4095), West Branch of the Wading (409815), and Oswego (4100) Rivers; the downstream stations on the Great Egg Harbor River (4110 and 41111); the stations on the North Branch of the Pennsauken Creek (467069) and South Branch of the Big Timber (467329) Creek; and the upstream station on the Maurice River (4115).

\section{Fraction of Dissolved Oxygen at Saturation}

The fraction of dissolved oxygen at saturation is the ratio of the measured DO concentration to the maximum DO concentration possible in the water. The maximum DO concentration possible is a function of atmospheric pressure, water temperature, and specific 
conductance of the water sample. Values are determined from published equations. The calculation of the fraction of dissolved oxygen at saturation removes the effect of temperature on oxygen solubility so that the effects of photosynthesis on DO concentration are easier to evaluate. Loads of percent dissolved oxygen saturation were not calculated.

\section{$\underline{\text { Relation of trends in concentration to flow conditions }}$}

No trends in the fraction of dissolved oxygen at saturation during high flows are apparent at the one station on the Toms River (4085); the downstream station on the Assunpink Creek (4640), the stations on the McDonalds Branch (4665), Cooper River (46715), Raccoon Creek (47712), and Cohansey River (4128); and the upstream station on the Maurice River (4115) (figs. 24a and 25a). The trends in the fraction of dissolved oxygen at saturation during low flows are positive at stations on the Manasquan River (4080) and Oldmans Creek (47751); trends are negative at the downstream station on the Great Egg Harbor River (41111) and stations on the South Branch of the Rancocas (46585) and Raccoon (47712) Creeks (figs. 24a and 25a). No trends are apparent at the stations on the Toms (4085) and Mullica (409387) Rivers, Hammonton Creek (409416), Batsto (4095), West Branch of the Wading (409815), Oswego (4100), and East Branch of the Bass (41015) Rivers; the upstream stations on the Great Egg Harbor River (410784 and 4110); and all stations on the Crosswicks (4645) and Doctors (464515) Creeks, McDonalds Branch (4665), North Branch on the Rancocas Creek (4670), North (467069) and South (467081) Branches of the Pennsauken Creek, and Salem (4825), Cohansey (4128), and Maurice (4115 and 4118) Rivers (figs. $24 \mathrm{~b}$ and 25b).

\section{Total Phosphorus}

Phosphorus is present in surface water as orthophosphates, condensed phosphates (pyro-, meta-, and other polyphosphates), and organically bound phosphates (Sawyer and McCarty, 1978). Phosphates are found in solution, associated with particles, detritus, and the bodies of aquatic organisms. They are derived from a variety of sources and are relatively immobile in soils or sediments (Hem, 1985). Phosphorus is a common element in igneous rock and is fairly abundant in sediment. Orthophosphates applied to agricultural or residential land as fertilizers can be carried into surface water with storm runoff. Phosphorus is an essential nutrient and can limit the primary productivity of a water body. Primary productivity is a measure of the rate at which new organic matter is formed and accumulated through photosynthetic and chemosynthetic activity of producer organisms (chiefly, green plants) (Barnes and Mann, 1991). The addition of phosphorus to surface water from storm runoff and the discharge of treated wastewater, agricultural drainage, or certain industrial wastes to the water can stimulate the growth of photosynthetic aquatic micro- and macro-organisms in nuisance quantities.

\section{$\underline{\text { Relation of trends in concentration to flow conditions }}$}

The trend in total phosphorus concentrations during high flows are negative at the one station on the Toms River (4085) and the upstream station on the Maurice River (4115), indicating a decrease in the contributions from storm runoff over time at these stations (figs. 26a and 27a). The trend of total phosphorus concentrations during low flows is negative at the one station on the Toms River (4085), indicating a decrease in the contributions from point sources 

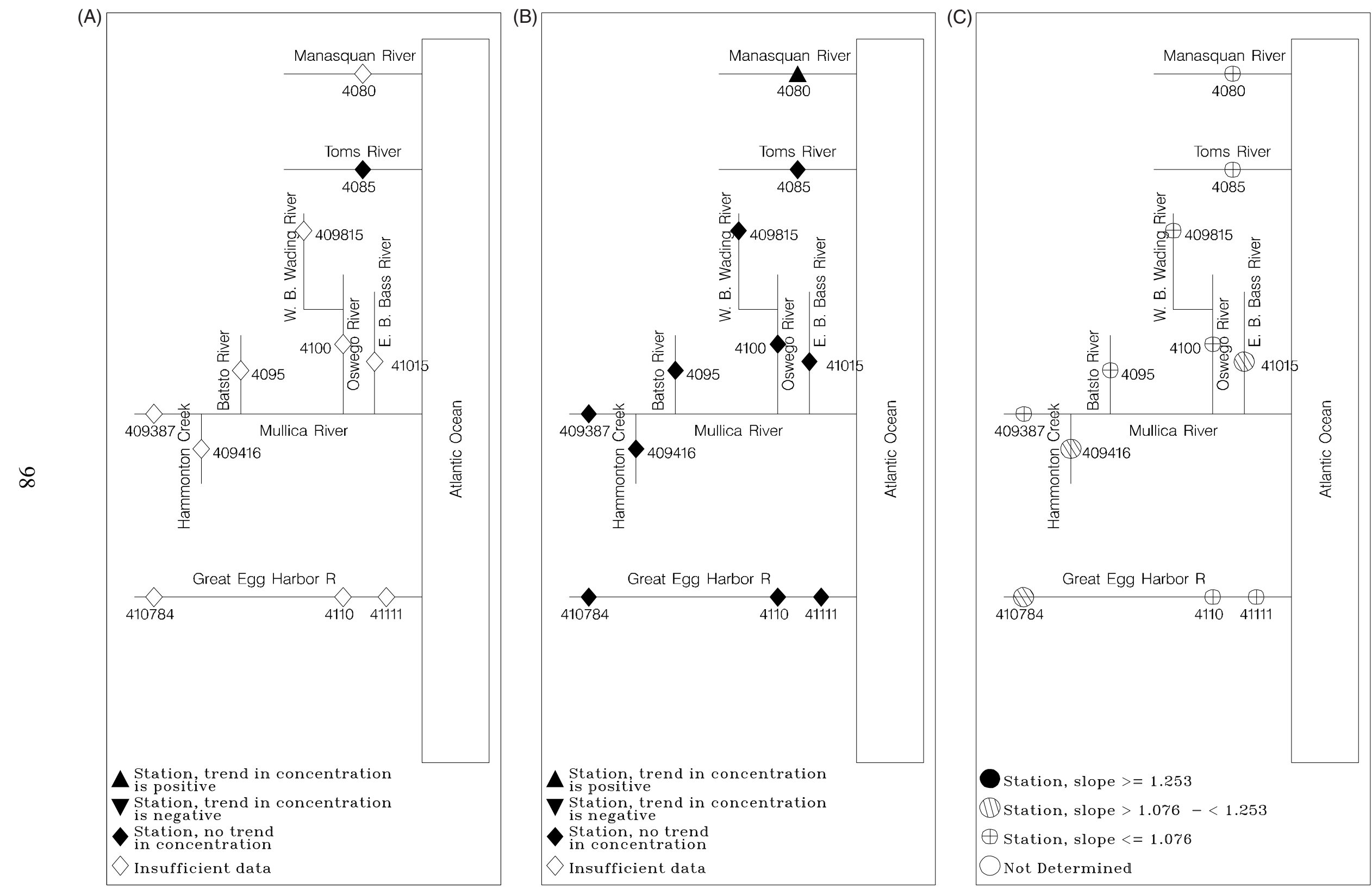

Figure 22. Trends in dissolved oxygen concentrations during (A) high- and (B) low-flow conditions, and (C) relative slope of dissolved oxygen load to streamflow at surface-water-quality stations in the Atlantic Coastal Basins, N.J., water years 1976-93. 
(A)
(B)

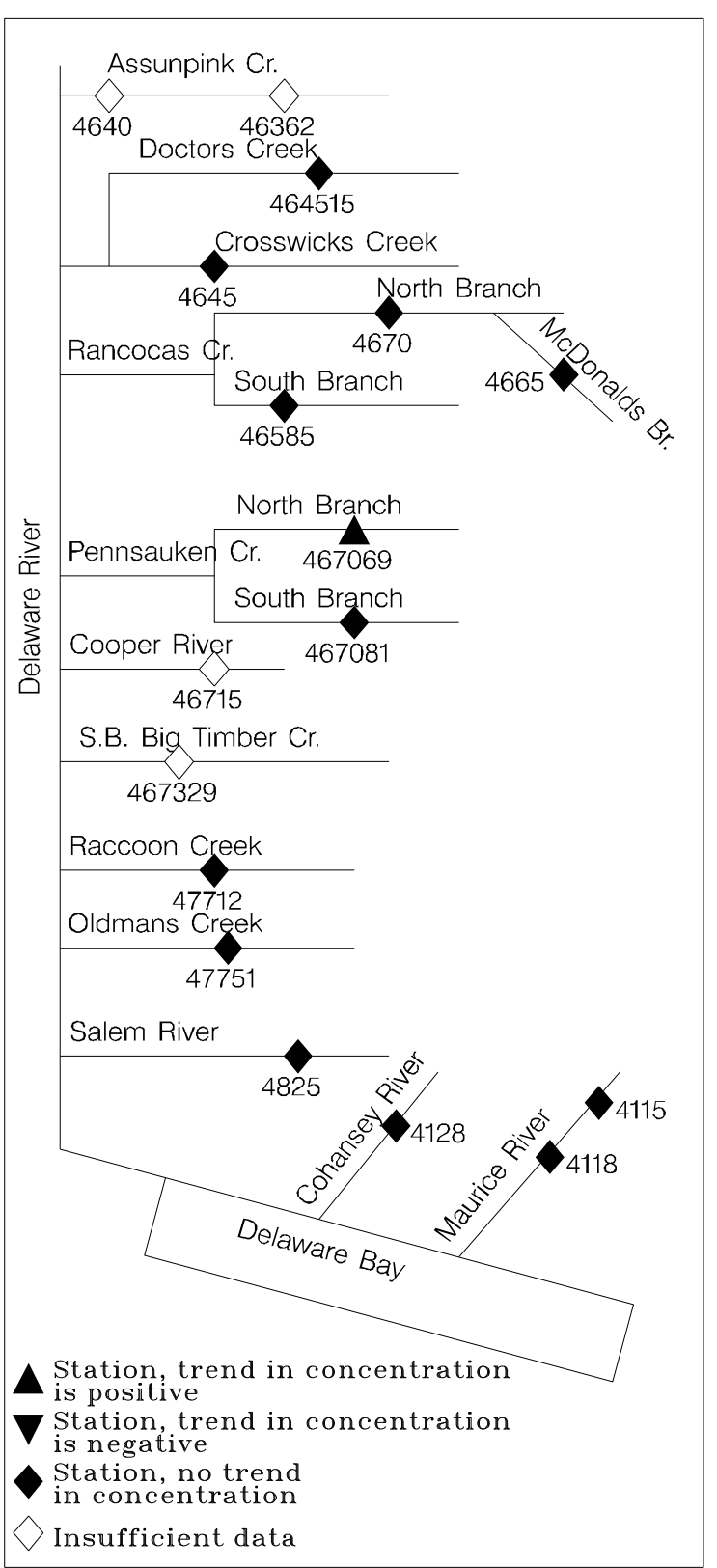

(C)

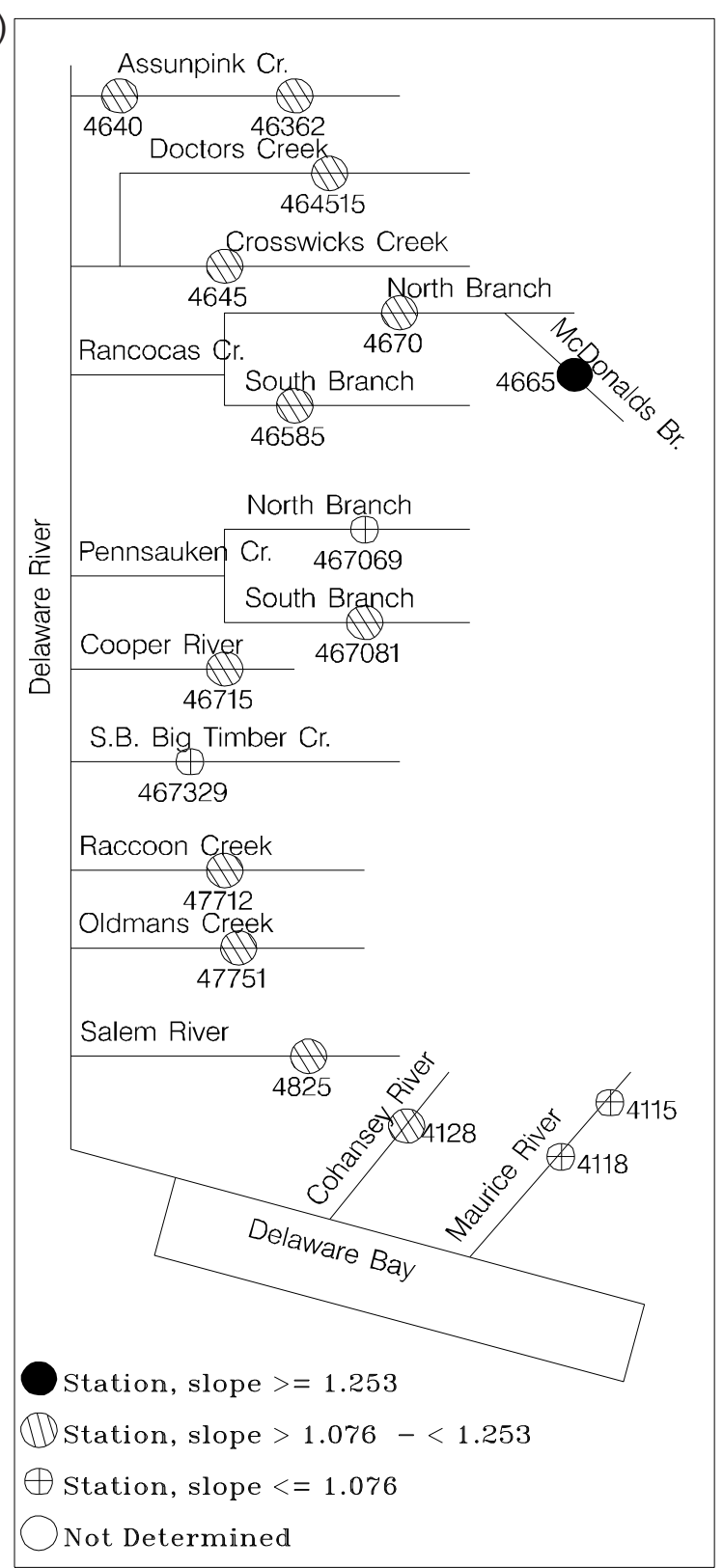

Figure 23. Trends in dissolved oxygen concentrations during (A) high- and (B) low-flow conditions, and (C) relative slope of dissolved oxygen load to streamflow at surface-water-quality stations in the lower Delaware River and Delaware Bay Basins, N.J., water years 1976-93. 

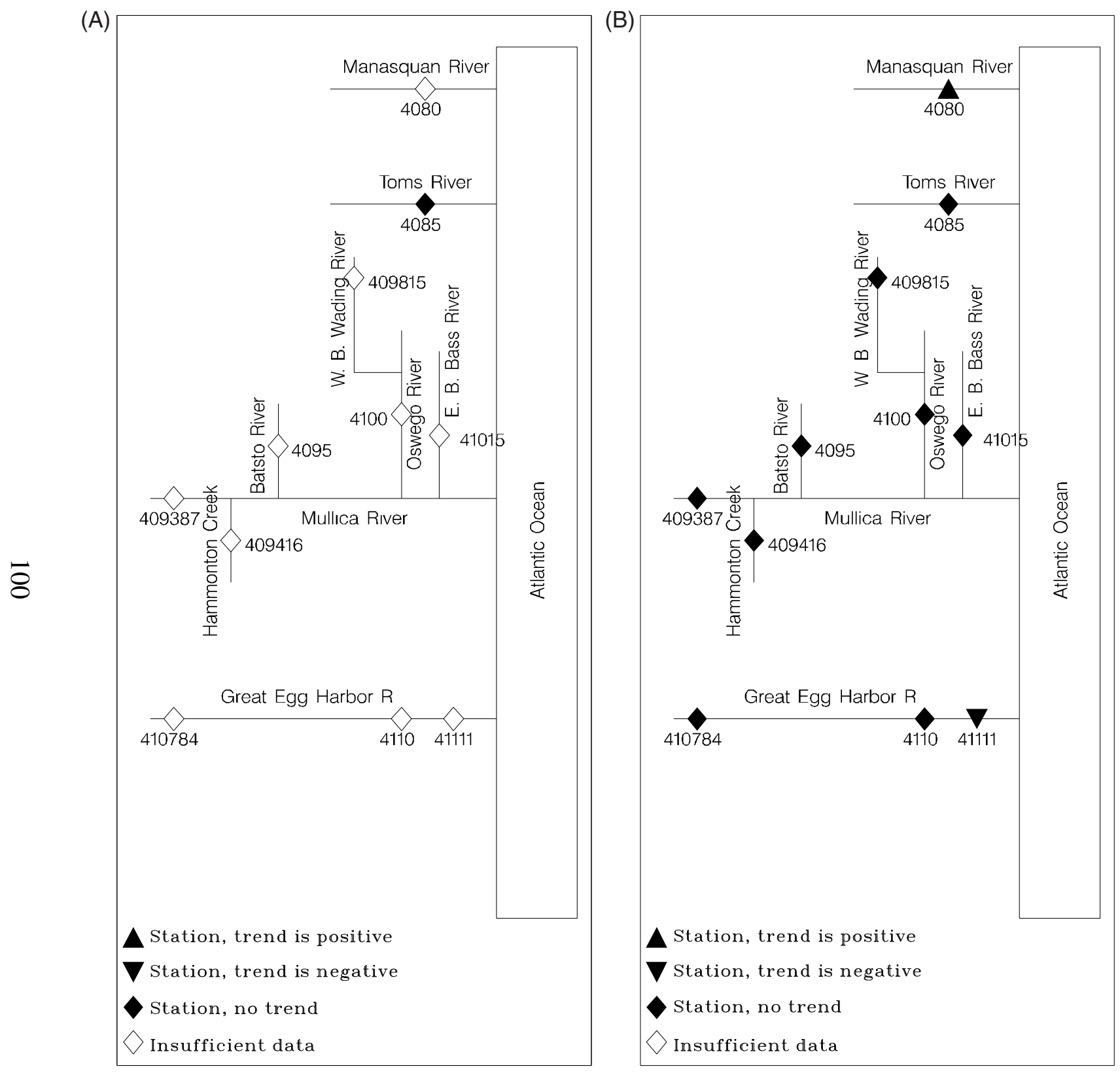

Figure 24. Trends in fraction of dissolved oxygen at saturation during $(A)$ high- and $(B)$ low-flow conditions at surface-water-quality stations in the Atlantic Coastal Basins, N.J., water years 1976-93. 

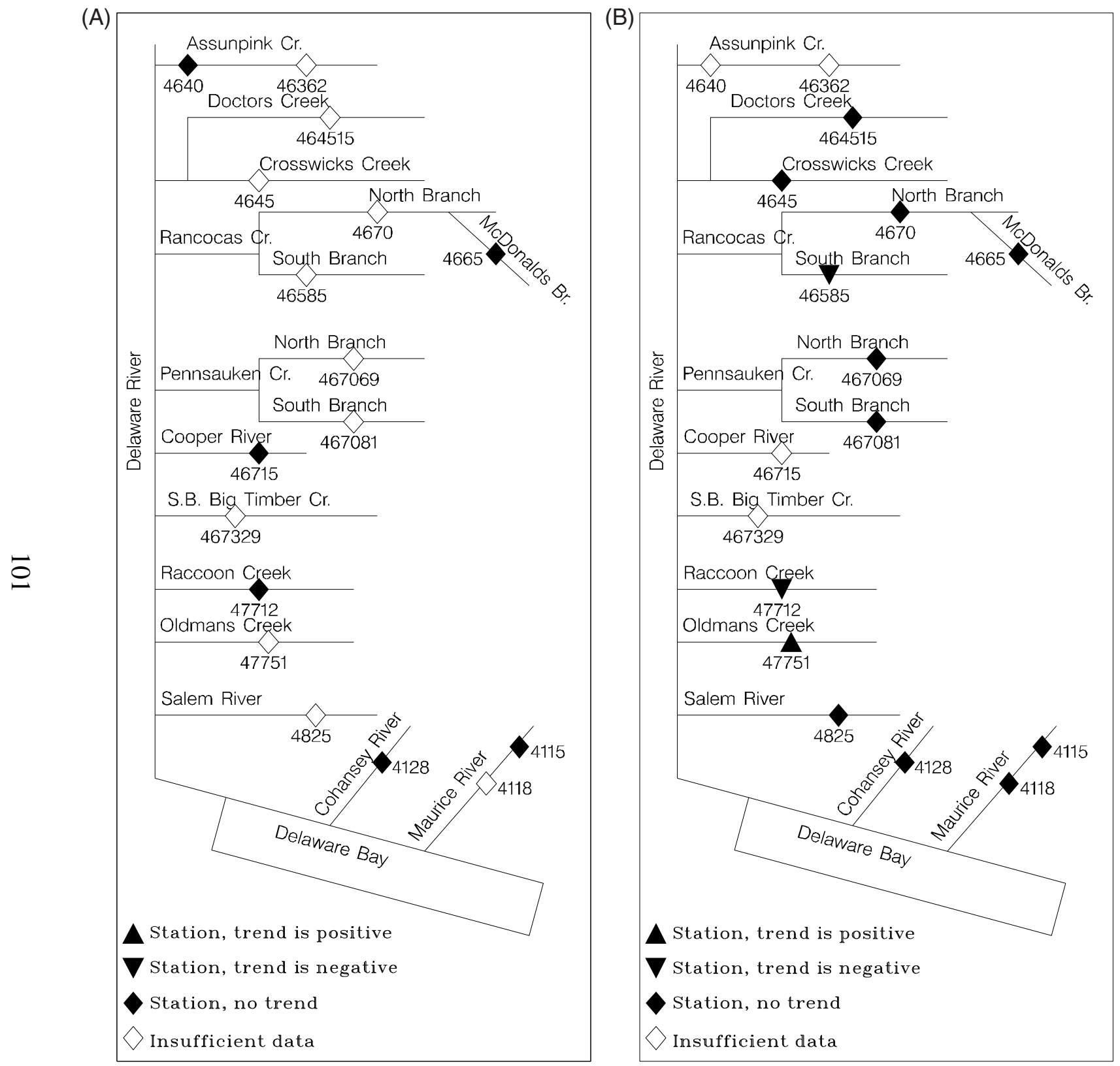

Figure 25. Trends in fraction of dissolved oxygen at saturation during (A) high- and (B) low-flow conditions at surface-water-quality stations in the lower Delaware River and Delaware Bay Basins, N.J., water years 1976-93. 

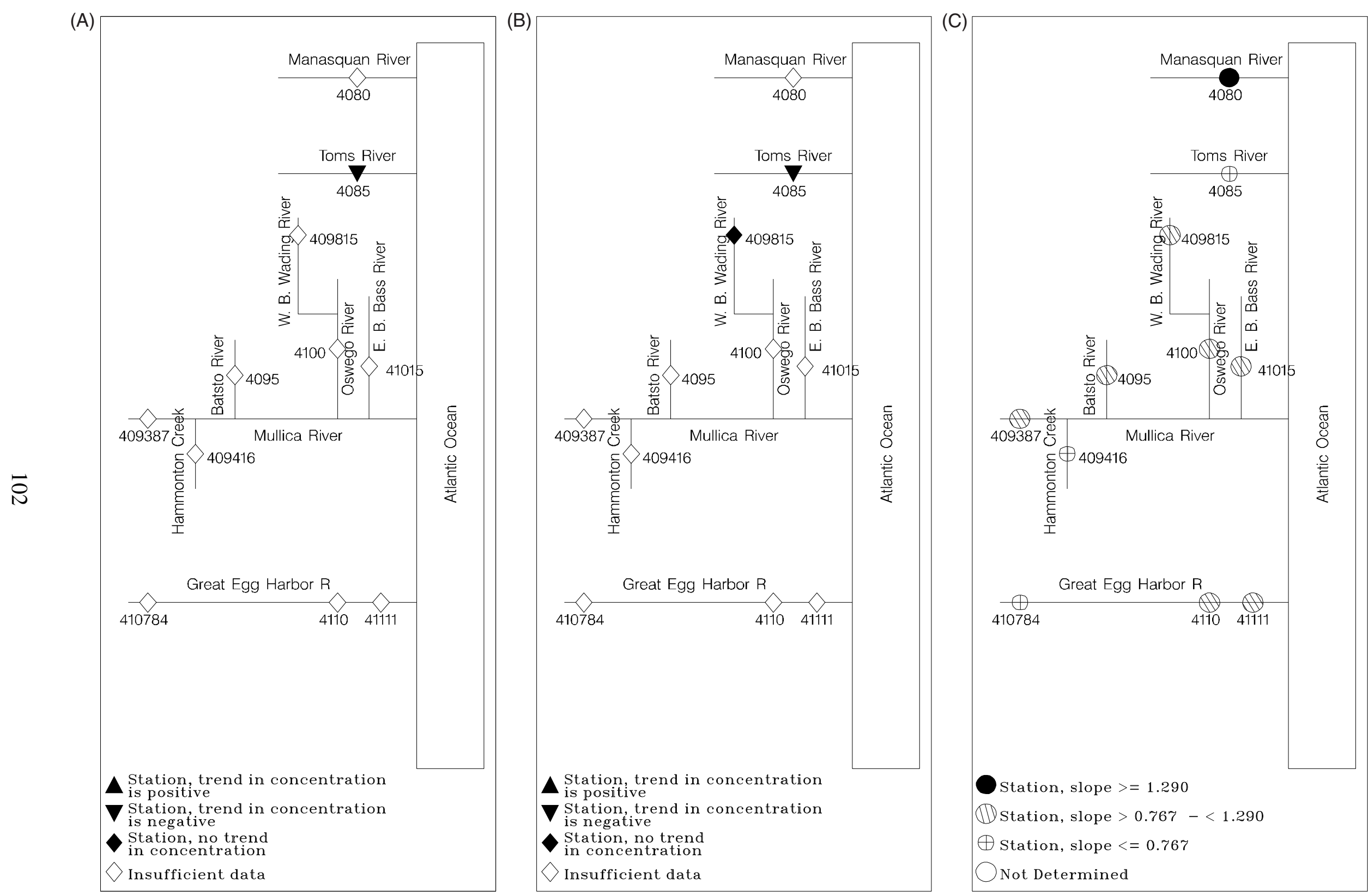

Figure 26. Trends in total phosphorus concentrations during $(A)$ high- and $(B)$ low-flow conditions, and $(C)$ relative slope of total phosphorus load to streamflow at surface-water-quality stations in the Atlantic Coastal Basins, N.J., water years 1976-93. 

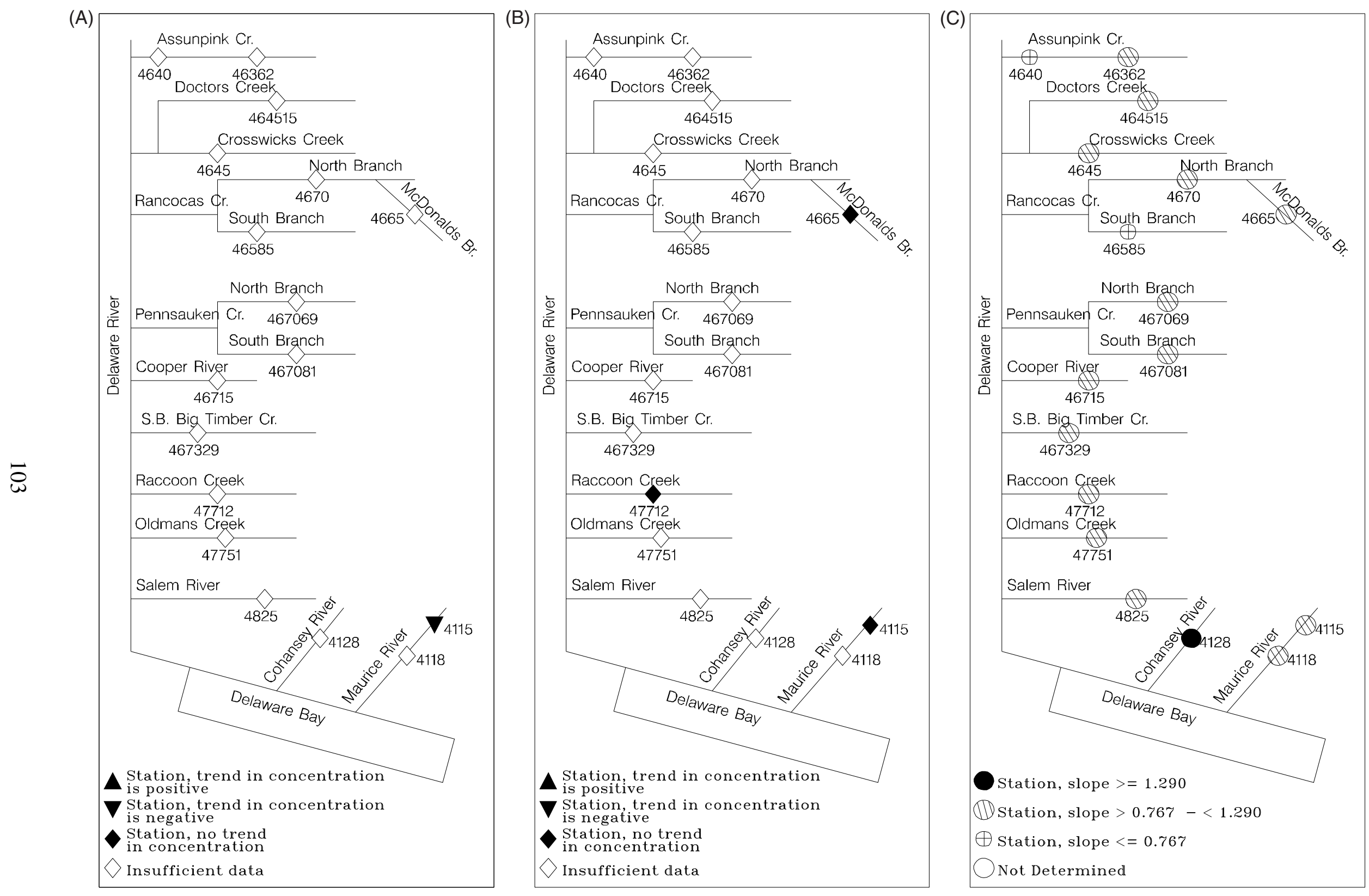

Figure 27. Trends in total phosphorus concentrations during (A) high- and (B) low-flow conditions, and (C) relative slope of total phosphorus load to streamflow at surface-water-quality stations in the lower Delaware River and Delaware Bay Basins, N.J., water years 1976-93. 
and ground water over time at this station (figs. 26 and 27b). The concentrations of total phosphorus during low flows show no trend at the stations on the West Branch of the Wading River (409815), McDonalds Branch (4665), and Raccoon Creek (47712), and the upstream station on the Maurice River (4115).

\section{Relation of load to streamflow}

The range categories of regression slopes of total phosphorus load to streamflow are depicted in figures 26c and 27c. The slopes range from 0.505 at station 409416 on the Hammonton Creek (table 8a) to 1.552 at station 4128 on the Cohansey River (table 30a). Slopes are in the high range at stations on the Manasquan (4080) and Cohansey (4128) Rivers, where the contributions to instream total phosphorus loads from storm runoff are larger and less influenced by point sources and ground water than at other sites in the study area. Slopes are in the low range at the stations on the Toms River (4085) and Hammonton Creek (409416), the upstream station on the Great Egg Harbor River (410784), the downstream station on the Assunpink Creek (4640), and the one station on the South Branch of the Rancocas Creek (46585). At these sites, the contributions to instream total phosphorus from point sources and ground water are larger and less influenced by storm runoff than at other sites in the study area. Slopes at stations on the Great Egg Harbor River increase in the downstream direction, indicating an increase in the relative influence of contributions from storm runoff along the river. Slopes at stations on the Assunpink Creek decrease in the downstream direction, indicating a decrease in the relative influence of contributions from storm runoff along the river.

\section{Total Nitrogen}

Nitrogen is an essential element for plant and animal growth; however, sufficiently large concentrations of certain nitrogen species can adversely affect the quality of surface water by causing excess algal growth (eutrophication) or toxicity to aquatic and terrestrial animals. Important forms of nitrogen in surface water are, in order of decreasing oxidation state, nitrate, nitrite, ammonia, and organic nitrogen. The cycling of nitrogen is mainly controlled by biological processes. Nitrogen enters aquatic environments from fertilizers, agricultural wastes, decomposition of organic matter, atmospheric deposition, biotic fixation, and ambient soils and rocks. Ground water and storm runoff are important sources of nitrate and ammonia to surface water. High concentrations of nitrate and nitrite can reduce the oxygen-carrying capacity of hemoglobin in warm-blooded animals. Un-ionized ammonia can be toxic to aquatic organisms.

\section{$\underline{\text { Relation of trends in concentration to flow conditions }}$}

The trend in total nitrogen concentrations during high flows is negative at the one station on the Cooper River (46715), indicating a decrease in the contribution from storm runoff over time at this station (figs. 28a and 29a). The concentrations of total nitrogen show no trends during high flows at the stations on the Toms River (4085), Raccoon Creek (47712), and Cohansey River (4128), and the upstream station on the Maurice River (4115) (figs. 28a and 29a). During low flow, the trend in total nitrogen concentrations is negative at the stations on the North (467069) and South (46708) Branches of the Pennsauken Creek, indicating a decrease in the contributions from point sources and ground water over time at these station (figs. 28b and 29b). Total nitrogen 
concentrations during low flows show no trend at all stations on the Toms (4085) and Mullica (409387) Rivers, Hammonton Creek (409416), Batsto (4095), Oswego (4100), East Branch of the Bass (41015), and Great Egg Harbor (410784, 4110, and 41111) Rivers, Crosswicks (4645) and Doctors Creeks (464515), South (46585) and North (4670) Branches of the Rancocas Creek, Raccoon (47712) and Oldmans (47751) Creeks, and Salem (4825), Cohansey (4128), and Maurice (4115 and 4118) Rivers.

\section{$\underline{\text { Relation of load to streamflow }}$}

The range categories of regression slopes of total nitrogen load to streamflow are shown in figures $28 \mathrm{c}$ and 29c. The slopes range from 0.645 at the upstream station on the Great Egg Harbor River (410784) (table 13a) to 1.387 at station 4665 on McDonalds Branch (table 21a). Slopes are in the high range at the stations on the Manasquan (4080) and Batsto (4095) Rivers, McDonalds Branch (4665), Raccoon Creek (47712), and Salem River (4825). At these sites, the contributions to instream total nitrogen loads from storm runoff are larger and less influenced by constant sources than at other sites in the study area. Slopes are in the low range at the stations on the Toms River (4085) and Hammonton Creek (409416), the upstream station on the Great Egg Harbor River (410784), the downstream station on the Assunpink Creek (4640), the stations on the Crosswicks (4645) and South Branch on the Pennsauken (467081) Creeks, and the upstream station on the Maurice River (4115). At these sites, the contribution to the instream total nitrogen load from point sources and (or) ground water is larger and less influenced by storm runoff than at other sites in the study area. Slopes at stations on the Great Egg Harbor River increase in the downstream direction, indicating an increase in the relative influence of contributions from storm runoff along the river. Slopes at stations on the Assunpink Creek decrease in the downstream direction, indicating a decrease in the relative influence of contributions from storm runoff along the river.

\section{Total Nitrate Plus Nitrite}

Total oxidized nitrogen concentration is the sum of the nitrate and nitrite concentrations. Nitrite is an intermediate oxidation state of nitrogen. Nitrite is usually present in trace amounts in surface water because it is rapidly oxidized to nitrate and is generally considered to be an indicator of the presence of sewage or organic waste (low DO conditions). Nitrite can enter surface water in discharge from wastewater-treatment plants and water-reuse systems in fish culture facilities where the nitrification process to reduce ammonia concentrations is impaired (Rand and Petrocelli, 1985). Nitrite is the etiologic agent of methemoglobinemia in humans and fish. Under specific conditions, nitrite is involved in the formation of some carcinogenic nitrosamines. Nitrate is an essential nutrient for many photosynthetic autotrophs and, in some cases, has been identified as the growth-limiting nutrient. It is present generally in trace amounts in surface water, but can attain high levels in some ground-water systems (Hem, 1985). Nitrate fertilizers applied to agricultural and residential land, then carried to surface water by storm runoff and ground water, can stimulate the growth of photosynthetic aquatic micro- and macroorganisms. Nitrate is considerably less toxic to aquatic organisms than are ammonia and nitrite; however, in excess amounts $(>10 \mathrm{mg} / \mathrm{L})$, nitrate contributes to methemoglobinemia in small children and fish. 

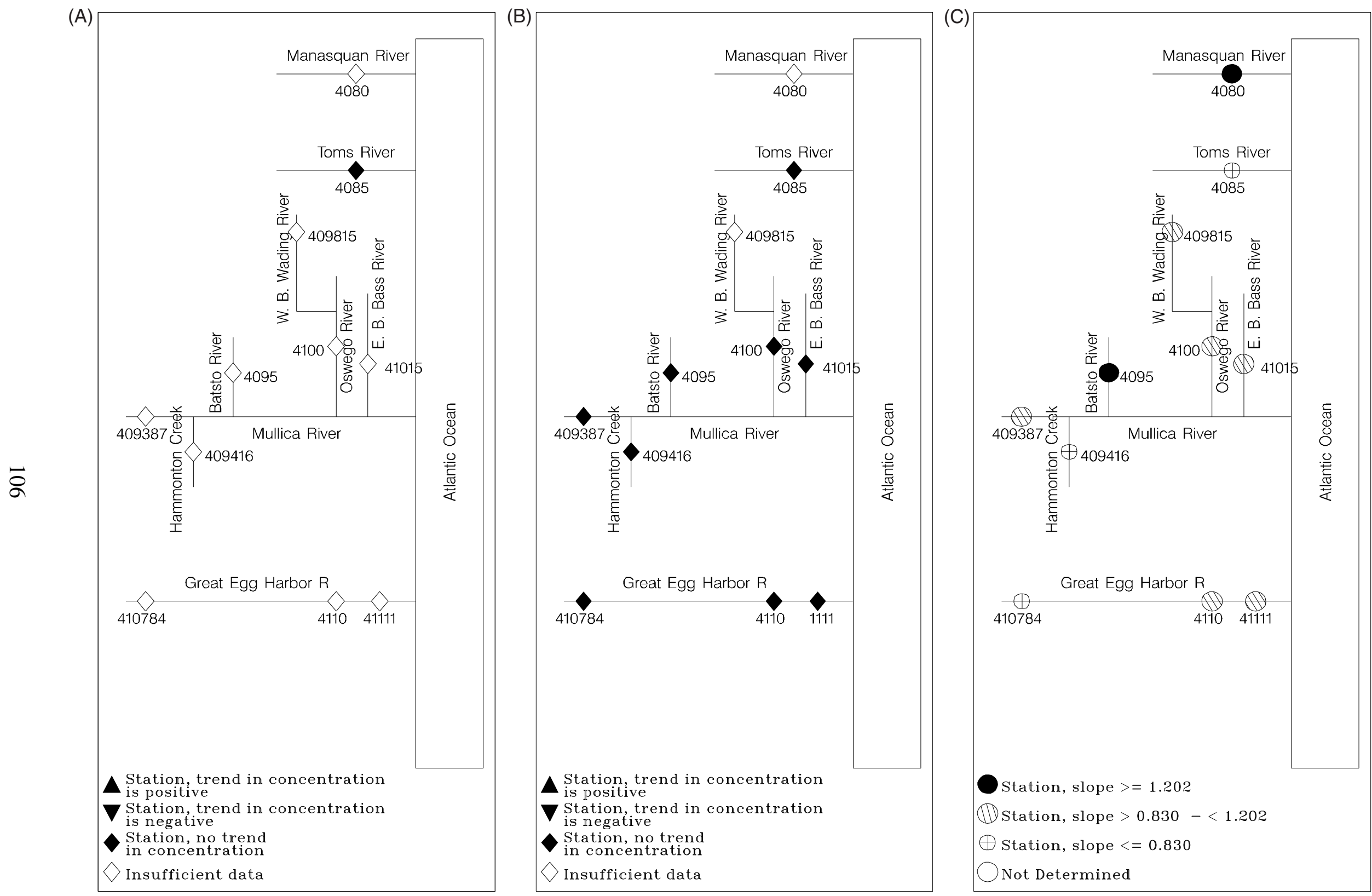

Figure 28. Trends in total nitrogen concentrations during (A) high- and (B) low-flow conditions, and (C) relative slope of total nitrogen load to streamflow at surface-water-quality stations in the Atlantic Coastal Basins, N.J., water years 1976-93. 

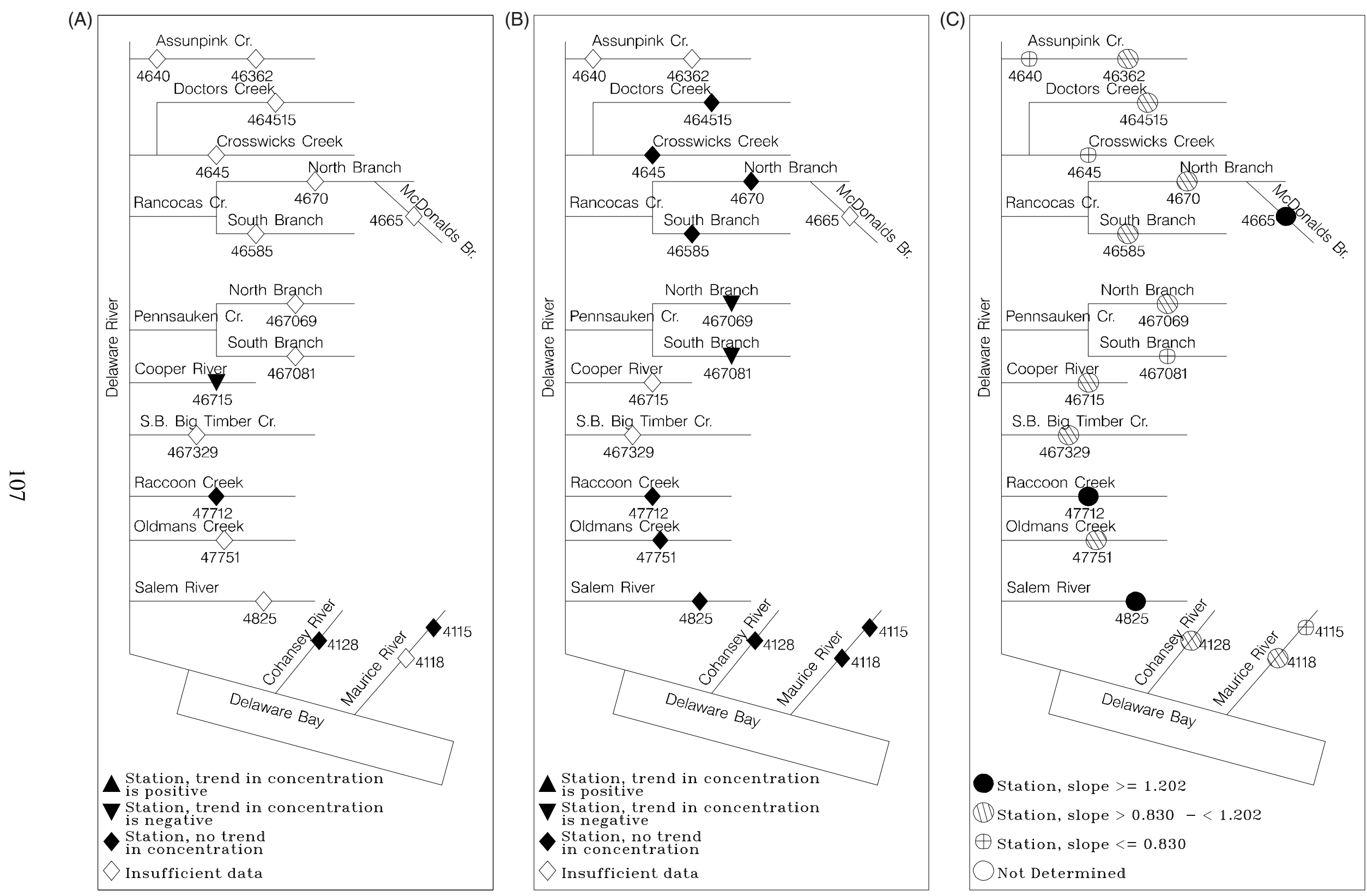

Figure 29. Trends in total nitrogen concentrations during (A) high- and (B) low-flow conditions, and (C) relative slope of total nitrogen load to streamflow at surface-water-quality stations in the lower Delaware River and Delaware Bay Basins, N.J., water years 1976-93. 


\section{Relation of trends in concentration to flow conditions}

Concentrations of total nitrate plus nitrite show no trends during high flows at the one station on the Toms River (4085); the downstream station on the Assunpink Creek (4640); the stations on the Cooper River (46715), Raccoon Creek (47712), and Cohansey River (4128); and the upstream station on the Maurice River (4115) (figs. 30a and 31a). The trend in total nitrate plus nitrite concentrations during low flows is positive at the one station on the South Branch of the Rancocas Creek (46585), indicating an increase in the contributions from point sources and ground water over time at this site (figs. $30 \mathrm{~b}$ and $31 \mathrm{~b}$ ). The trend in total nitrate plus nitrite concentrations during low flows is negative at the upstream station on the Great Egg Harbor River (410784) and the one station on the North Branch of the Pennsauken Creek (467069), indicating a decrease in the contributions from point sources and (or) ground water over time at these sites. Increased discharge from wastewater-treatment plants in which the organic nitrogen is almost entirely oxidized can result in increased nitrate plus nitrite concentrations in the receiving streams. Concentrations of total nitrogen during low flows show no trends at the stations on the Toms (4085) and Mullica (409387) Rivers, Hammonton Creek (409416), Batsto River (4095), Oswego River (4100), and East Branch of the Bass River (41015); the downstream stations on the Great Egg Harbor River (4110 and 41111); and all stations on the Crosswicks (4645) and Doctors (464515) Creeks, McDonalds Branch (4665), North Branch of the Rancocas Creek (4670), South Branch of the Pennsauken Creek (467081), Raccoon Creek (47712), Oldmans Creek (47751), and Salem (4825), Cohansey (4128), and Maurice (4115 and 4118) Rivers.

\section{$\underline{\text { Relation of load to streamflow }}$}

The range categories of regression slopes of total nitrate plus nitrite load to streamflow are depicted in figures 30c and 31c. The slopes range from 0.276 at the downstream station on the Great Egg Harbor River (41111) (table 15a) to 2.171 at station 4825 on the Salem River (table 29a). The slope is in the high range only at the one station on the Salem River (4825) where the contribution from storm runoff is larger and less influenced by constant sources than at other sites in the study area. The slopes are in the low range at the one station on the Toms River (4085), all stations on the Great Egg Harbor River (410784, 4110, and 41111), the downstream station on the Assunpink Creek (4640), the one station on the Crosswicks Creek (4645), and the upstream station on the Maurice River (4115). At these sites, the contributions from point sources and (or) ground water are larger and less influenced by storm runoff than at other sites in the study area. Slopes at stations on the Assunpink Creek decrease in the downstream direction, indicating a decrease in the relative influence of contributions from storm runoff along the river, whereas slopes at stations on the Maurice River increase in the downstream direction, indicating an increase in the relative influence of contributions from storm runoff along the river.

\section{Total Nitrite}

Nitrite is an intermediate oxidation state of nitrogen, both in the oxidation of ammonia to nitrate and in the reduction of nitrate. Nitrite species are unstable in aerated water and are generally considered to be indicators of the presence of sewage or organic waste (low DO conditions). Nitrite is the etiologic agent of methemoglobinemia. 


\section{$\underline{\text { Relation of trends in concentration to flow conditions }}$}

During high flows, trends in total nitrite concentrations were negative at the downstream station on the Assunpink Creek (4640) and the one station on the Cooper River (46715), indicating a decrease in the contributions from storm runoff over time at these sites (figs. 32a and 33a). The trends in total nitrite concentrations during low flows are insignificant at the stations on the Great Egg Harbor (4110) and Batsto (4095) Rivers and the downstream station on the Maurice River (4118) (figs. 32b and 33b).

\section{$\underline{\text { Relation of load to streamflow }}$}

The range categories of regression slopes of total nitrite load to streamflow are depicted in figures 32c and 33c. The slopes range from 0.234 at station 467081 on the South Branch of the Pennsauken Creek (table 24a) to 1.442 at station 4128 on the Cohansey River (table 30a). Insufficient data were available to determine the slopes at the stations on the West Branch of the Wading River (409815) and McDonalds Branch (4665). Slopes are in the high range at the stations on the Oswego (4100) and East Branch of the Bass (41015) Rivers, the downstream station on the Great Egg Harbor River (41111), the upstream station on the Assunpink Creek (46362), and the stations on the North Branch of the Rancocas Creek (4670), and the Cooper (46715), Salem (4825), and Cohansey (4128) Rivers. At these sites, the contributions to instream total nitrite loads from storm runoff are larger and less influenced by constant sources than at other sites in the study area. The slope is in the low range only at the one station on the South Branch of the Pennsauken Creek (467081) where the contribution to instream total nitrite loads from storm runoff is smaller and more influenced by point sources and (or) ground water than at other sites in the study area. Slopes at stations on the Great Egg Harbor River increase in the downstream direction, indicating an increase in the relative influence of contributions from storm runoff along the river, whereas slopes at stations on the Assunpink Creek decrease in the downstream direction, indicating a decrease in the relative influence of contributions from storm runoff along the river.

\section{Total Ammonia Plus Organic Nitrogen}

Organic nitrogen is defined as organically bound nitrogen in the tri-negative oxidation state. It includes many natural materials, such as proteins, peptides, nucleic acids, and urea, and synthetic organic compounds, but does not include all organic nitrogen compounds. Ammonia is produced by the deamination of organic nitrogen-containing compounds. Ammonia can enter surface water dissolved in wastewater effluent, storm runoff, and rain. Temperature, $\mathrm{pH}$, and ionic strength control the speciation of ammonia in surface water. The un-ionized form of ammonia, more common in low $\mathrm{pH}$ and low ionic strength waters, is toxic to fish. The total ammonia plus organic nitrogen concentrations are determined together by the kjeldahl method (Eaton and others, 1995). 

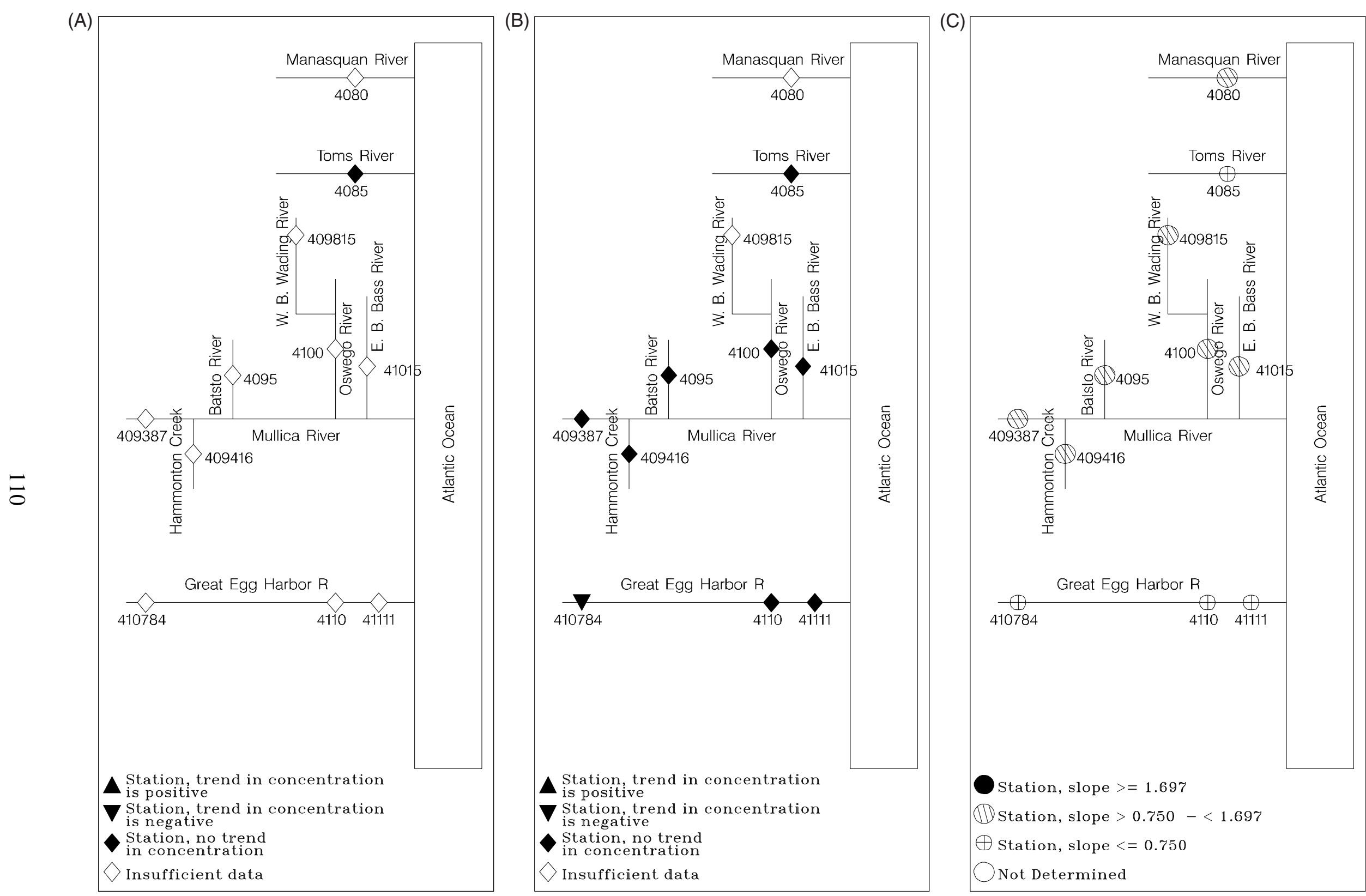

Figure 30. Trends in total nitrate plus nitrite concentrations during (A) high- and (B) low-flow conditions, and (C) relative slope of total nitrate plus nitrite load to streamflow at surface-water-quality stations in the Atlantic Coastal Basins, N.J., water years 1976-93. 

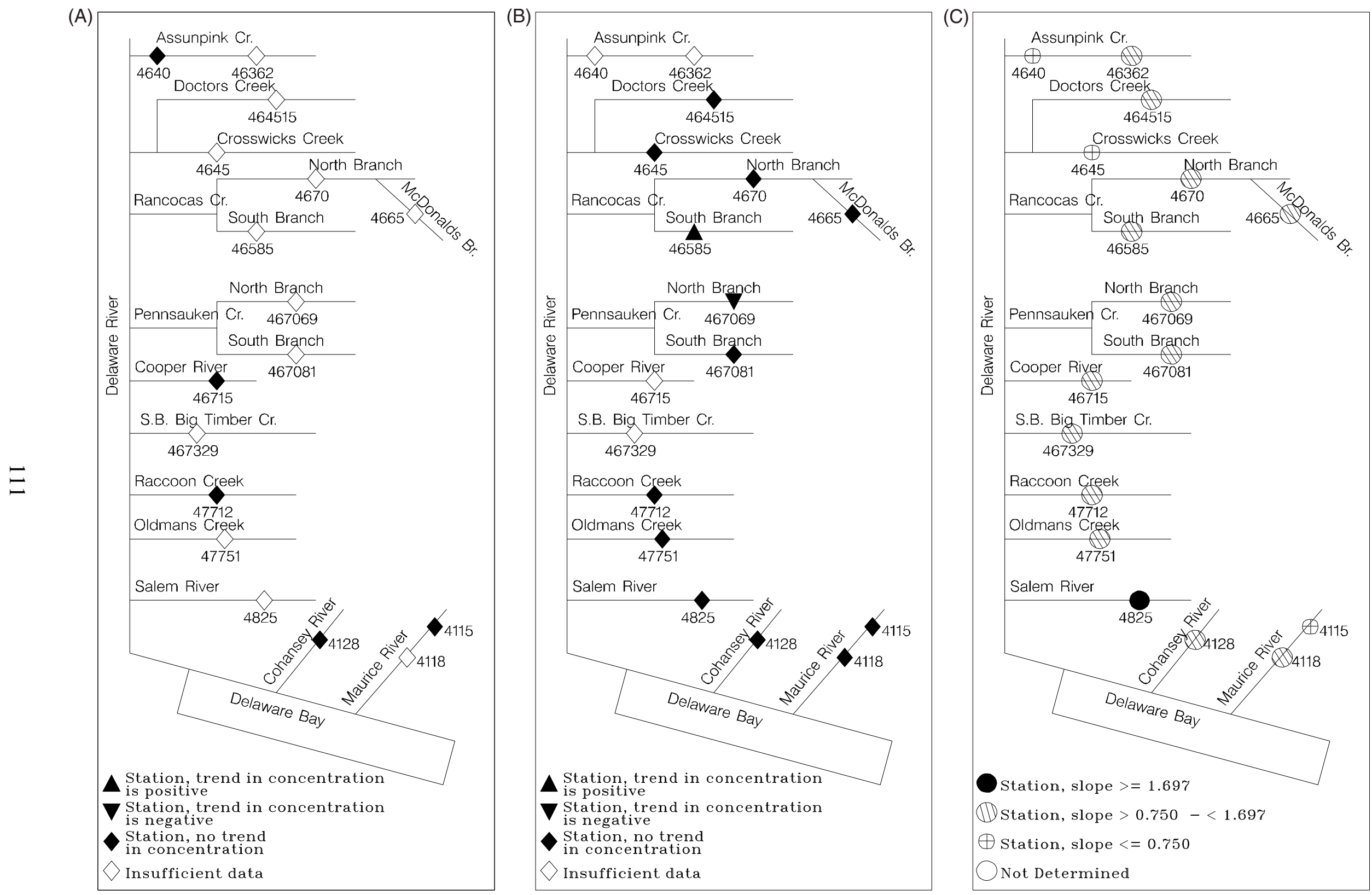

Figure 31. Trends in total nitrate plus nitrite concentrations during (A) high- and (B) low-flow conditions, and (C) relative slope of total nitrate plus nitrite load to streamflow at surface-water-quality stations in the lower Delaware River and Delaware Bay Basins, N.J., water years 1976-93. 

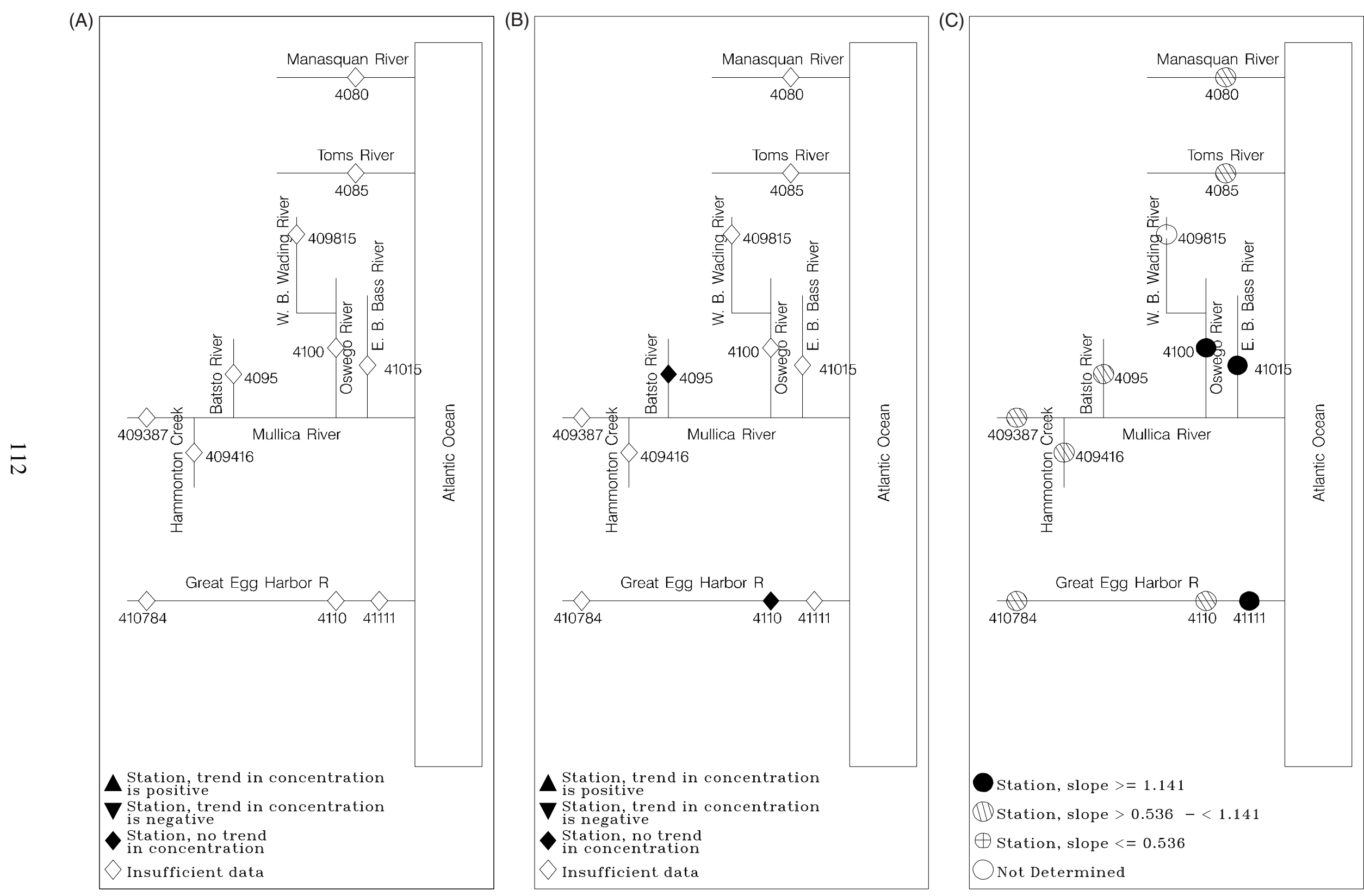

Figure 32. Trends in total nitrite concentrations during (A) high- and (B) low-flow conditions, and (C) relative slope of total nitrite load to streamflow at surface-water-quality stations in the Atlantic Coastal Basins, N.J., water years 1976-93. 

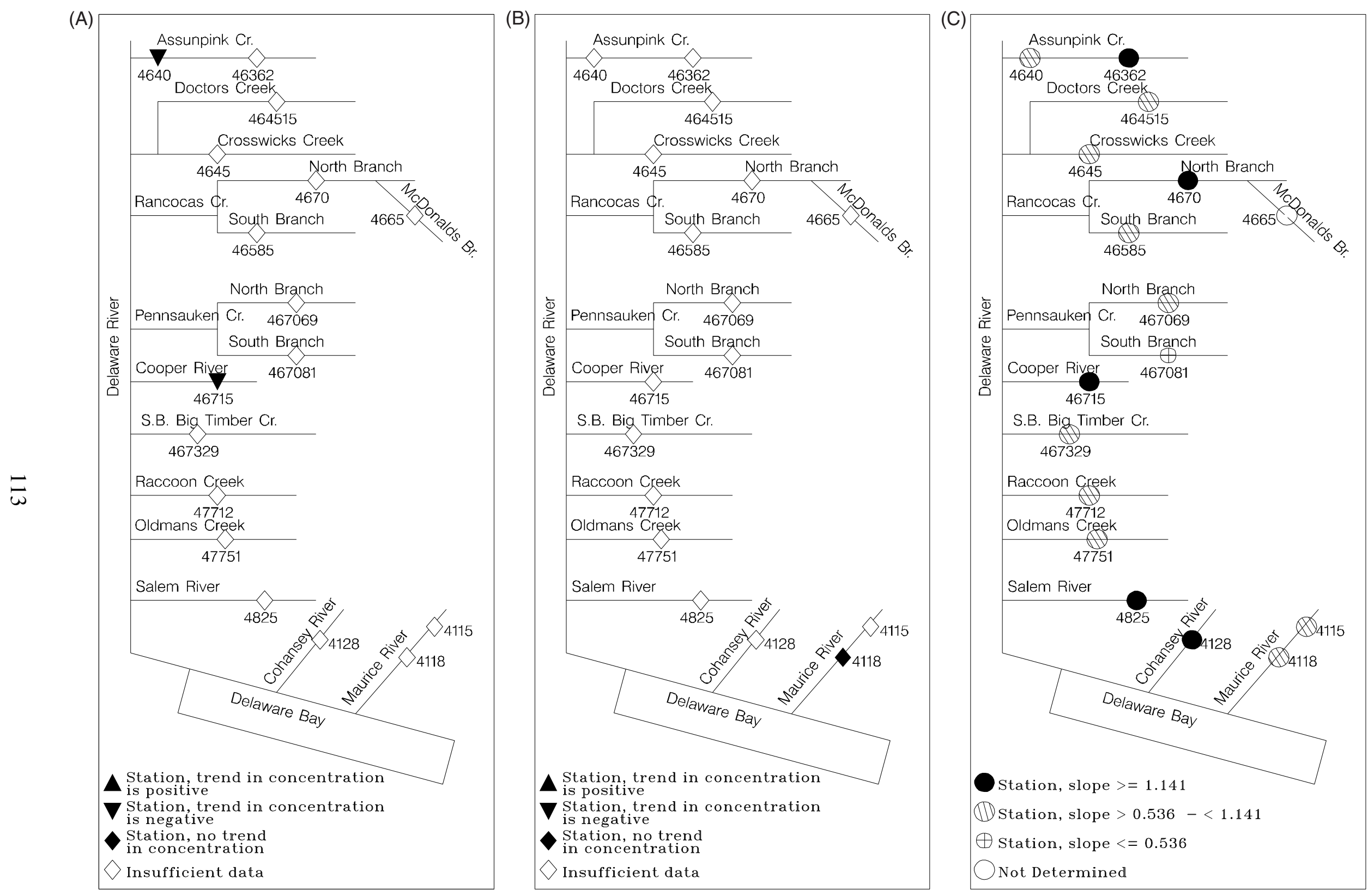

Figure 33. Trends in total nitrite concentrations during (A) high- and (B) low-flow conditions, and (C) relative slope of total nitrite load to streamflow at surface-water-quality stations in the lower Delaware River and Delaware Bay Basins, N.J., water years 1976-93. 


\section{$\underline{\text { Relation of trends in concentration to flow conditions }}$}

The trends in total ammonia plus organic nitrogen concentrations during high flows are negative at the one station on the Cooper River (46715), indicating a decrease in the contribution from storm runoff over time at this station (figs. 34a and 35a). The concentrations of total ammonia plus organic nitrogen during high flows show no trends at the stations on the Toms River (4085), Raccoon Creek (47712), and Cohansey River (4128), and the upstream station on the Maurice River (4115). The trends in total ammonia plus organic nitrogen concentrations during low flows are negative at the stations on the Manasquan (4080) and Oswego (4100) Rivers, the downstream stations on the Great Egg Harbor River (4110 and 41111), the stations on the Crosswicks Creek (4645) and North Branches of the Rancocas (4670) and Pennsauken (467081) Creeks (figs. 34b and 35b). Contributions from point sources and ground water decreased over time at these stations. Concentrations of total ammonia plus organic nitrogen during low flows show no trend at the stations on the Toms (4085) and Mullica (409387) Rivers, Hammonton Creek (409416), Batsto River (4095), West Branch of the Wading (409815) and East Branch of the Bass (41015) Rivers; the upstream station on the Great Egg Harbor River (410784); and all stations on the Doctors Creek (464515), South Branches of the Rancocas (46585) and Pennsauken Creeks (467081), Raccoon Creek (47712), Oldmans Creek (47751), and Salem (4825), Cohansey (4128), and Maurice (4115 and 4118) Rivers.

\section{$\underline{\text { Relation of load to streamflow }}$}

The range categories of regression slopes of total ammonia plus total organic nitrogen load to streamflow are depicted in figures $34 \mathrm{c}$ and $35 \mathrm{c}$. The slopes range from 0.691 at station 467081 on the South Branch of the Pennsauken Creek (table 24a) to 1.752 at station 4665 on the McDonalds Branch (table 21a). The slope is in the high range only at the station on the McDonalds Branch (4665) where the contribution to instream loads from storm runoff is larger and less influenced by constant sources than at other sites in the study area. Slopes are in the low range at the stations on the Mullica River (409387) and Hammonton Creek (409416); the downstream station on the Assunpink Creek (4640); the stations on the Doctors Creek (464515), South (46585) and North (4670) Branches of the Rancocas Creek, North (467069) and South (467081) Branches of the Pennsauken Creek, and Oldmans Creek (47751); and the downstream station on the Maurice River (4118). At these sites, the contributions to instream loads from point sources and ground water are larger and less influenced by storm runoff than at other sites in the study area. Slopes at stations on the Assunpink Creek and Maurice River decrease in the downstream direction, indicating a decrease in the relative influence of contributions from storm runoff along the rivers.

\section{Total Ammonia}

Ammonia is produced largely by deamination of organic nitrogen-containing compounds and by hydrolysis of urea. Ammonia can enter surface water by wet deposition with industrial, municipal, and agricultural wastewater and runoff, especially from areas treated with ammonia fertilizers. At some water-treatment plants, ammonia is added to react with chlorine to form a 
combined chlorine residual. Contributions of ammonia to surface water from ground water are usually small because ammonia readily adsorbs to soil particles and clays and does not leach from soils (Hem, 1985).

The toxicity of ammonia to fish is dependent on its speciation. Un-ionized ammonia is considered to be the toxic form to aquatic organisms (Rand and Petrocelli, 1985). The relative concentrations of ionized $\left(\mathrm{NH}^{+}\right)$and un-ionized $\left(\mathrm{NH}_{3}\right)$ ammonia are a function of the $\mathrm{pH}$, temperature, and ionic strength of the aqueous solution. When the $\mathrm{pH}$, temperature, and totalammonia concentration are measured in a solution, the relative concentrations of $\mathrm{NH}_{3}$ and $\mathrm{NH}_{4}{ }^{+}$ can be calculated. Decreased dissolved oxygen concentrations are often coincident with increased ammonia toxicity.

\section{$\underline{\text { Relation of trends in concentration to flow conditions }}$}

The trends in total ammonia concentrations during high flows are negative at the one station on the Cohansey River (4128), indicating a decrease in the contribution from storm runoff over time at this station, and insignificant at the one station on the Cooper River (46715) (figs. 36a and 37a). The trends in total ammonia concentrations during low flows are negative at the stations on the Doctors Creek (464515) and North Branches of the Rancocas (4670) and Pennsauken (467069) Creeks, indicating a decrease in the contribution from point sources and ground water over time at these stations (figs. $36 \mathrm{~b}$ and $37 \mathrm{~b}$ ). Total ammonia concentrations during low flows show no trends at all stations on the Mullica River (409387), Hammonton Creek (409416), Batsto River (4095), Oswego River (4100), East Branch of the Bass River (41015), Great Egg Harbor River (410784, 4110, and 41111), Crosswicks Creek (4645), South Branches of the Rancocas (46585) and Pennsauken (467081) Creeks, Raccoon (47712) and Oldmans (47751) Creeks, Salem (4825) and Cohansey (4128) Rivers, and the downstream station on the Maurice River (4118).

\section{$\underline{\text { Relation of load to streamflow }}$}

The range categories of regression slopes of total ammonia load are depicted in figures $36 \mathrm{c}$ and 37c. The slopes range from 0.415 at the downstream station on the Maurice River (4118) (table 32a) to 1.732 at the station 4080 on the Manasquan River (table 5a). Slopes are in the high range at the stations on the Manasquan (4080) and Batsto (4095) Rivers, where the contributions to instream total ammonia load from storm runoff are larger and less influenced by constant sources than at other sites in the study area. The slopes are in the low range at the stations on the Toms (4085), West Branch of the Wading (409815) and East Branch of the Bass Rivers (41015), Great Egg Harbor River (4110), Doctors Creek (464515), South (46588) and North (4670) Branches of the Rancocas Creek, and South Branch of the Pennsauken Creek (467081), and the downstream station on the Maurice River (4118). At these sites, the contributions to instream total ammonia loads from point sources and (or) ground water are larger and less influenced by storm runoff than at other sites in the study area. Slopes at stations on the Maurice River decrease in the downstream direction, indicating a decrease in the relative influence of contributions from storm runoff along the river. 

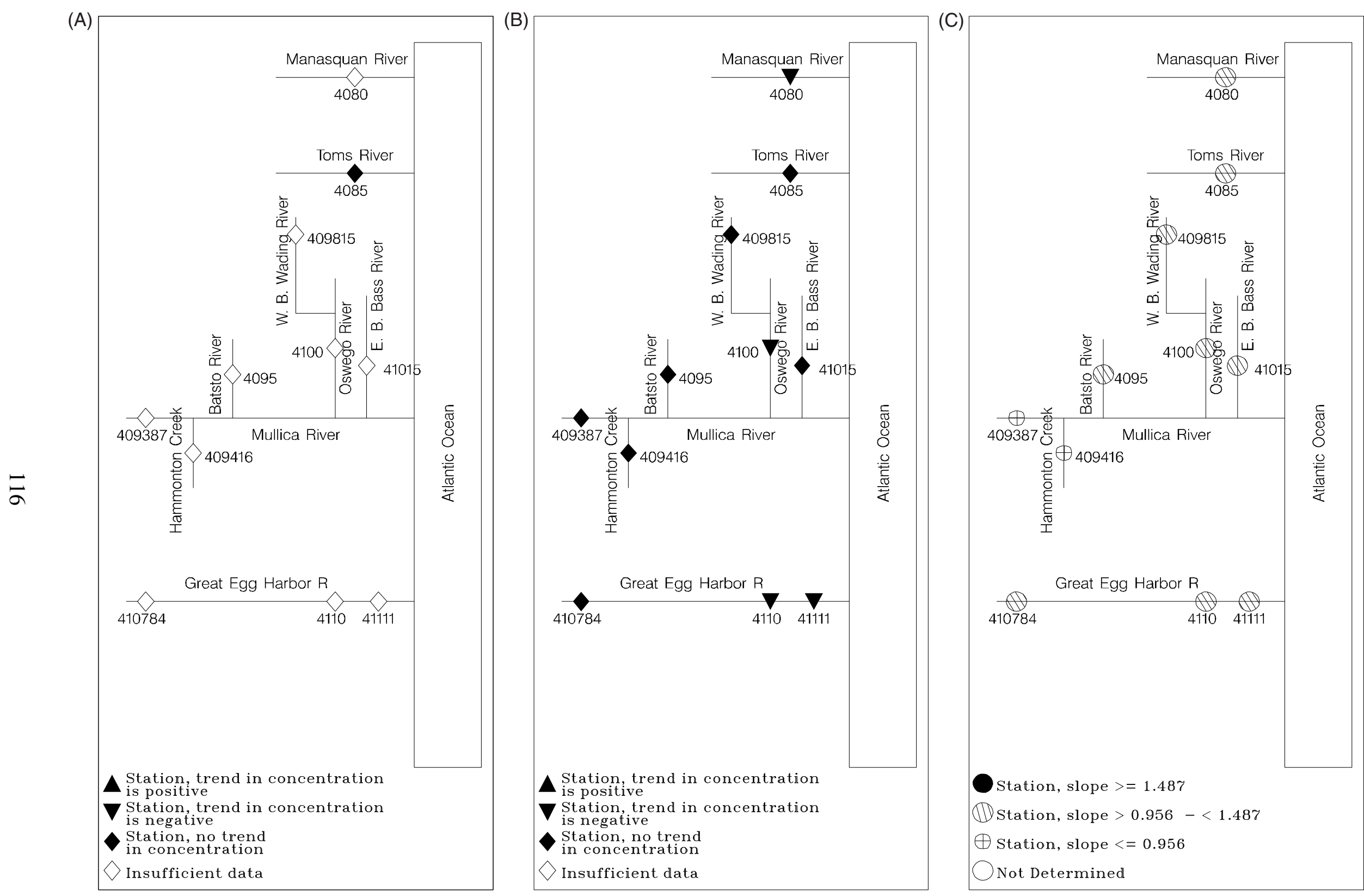

Figure 34. Trends in total ammonia plus organic nitrogen concentrations during (A) high- and (B) low-flow conditions, and (C) relative slope of total ammonia plus total organic nitrogen load to streamflow at surface-water-quality stations in the Atlantic Coastal Basins, N.J., water years 1976-93. 

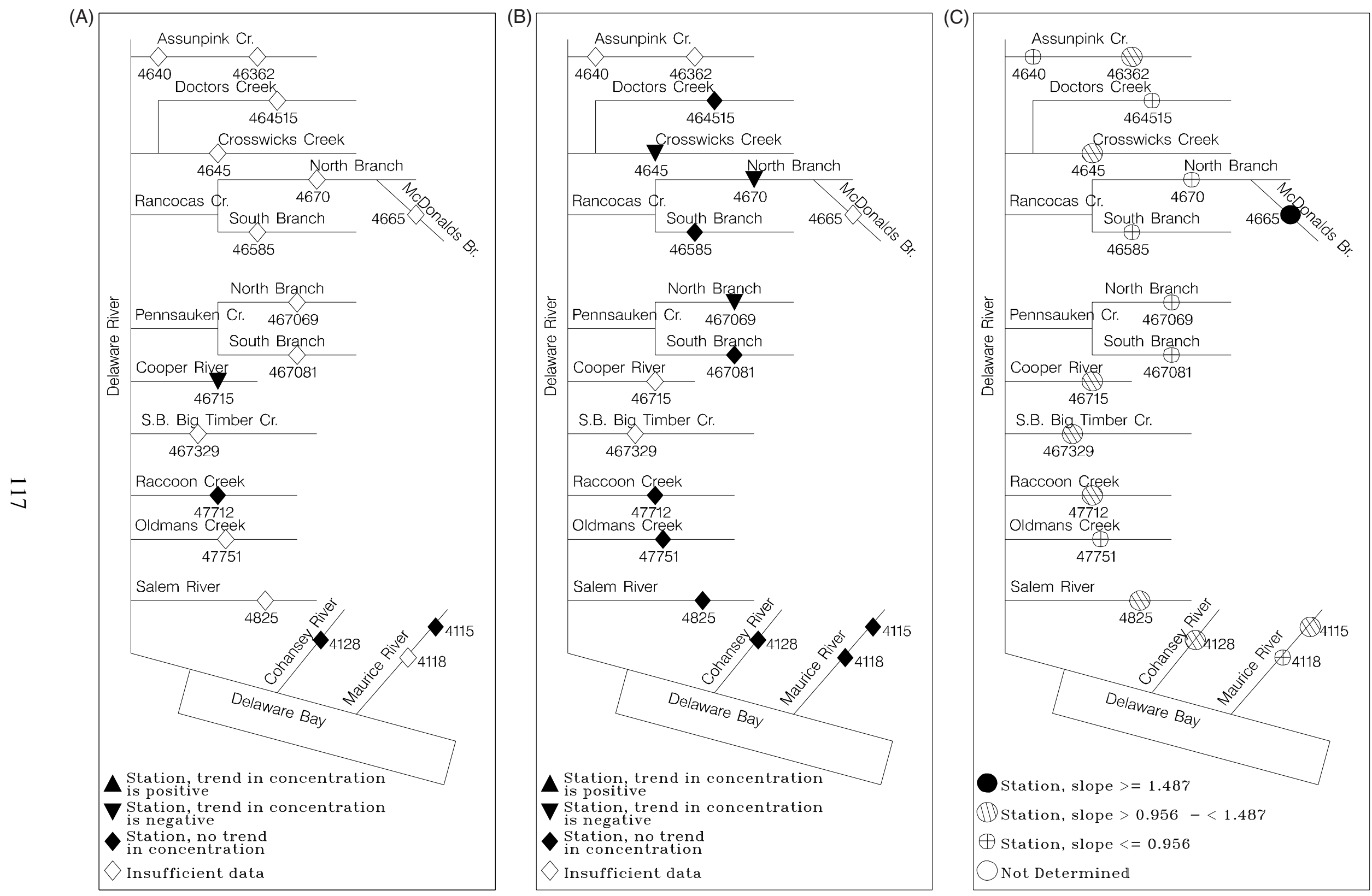

Figure 35. Trends in total ammonia plus organic nitrogen concentrations during (A) high- and (B) low-flow conditions, and (C) relative slope of total ammonia plus organic nitrogen load to streamflow at surface-water-quality stations in the lower Delaware River and Delaware Bay Basins, N.J., water years 1976-93. 

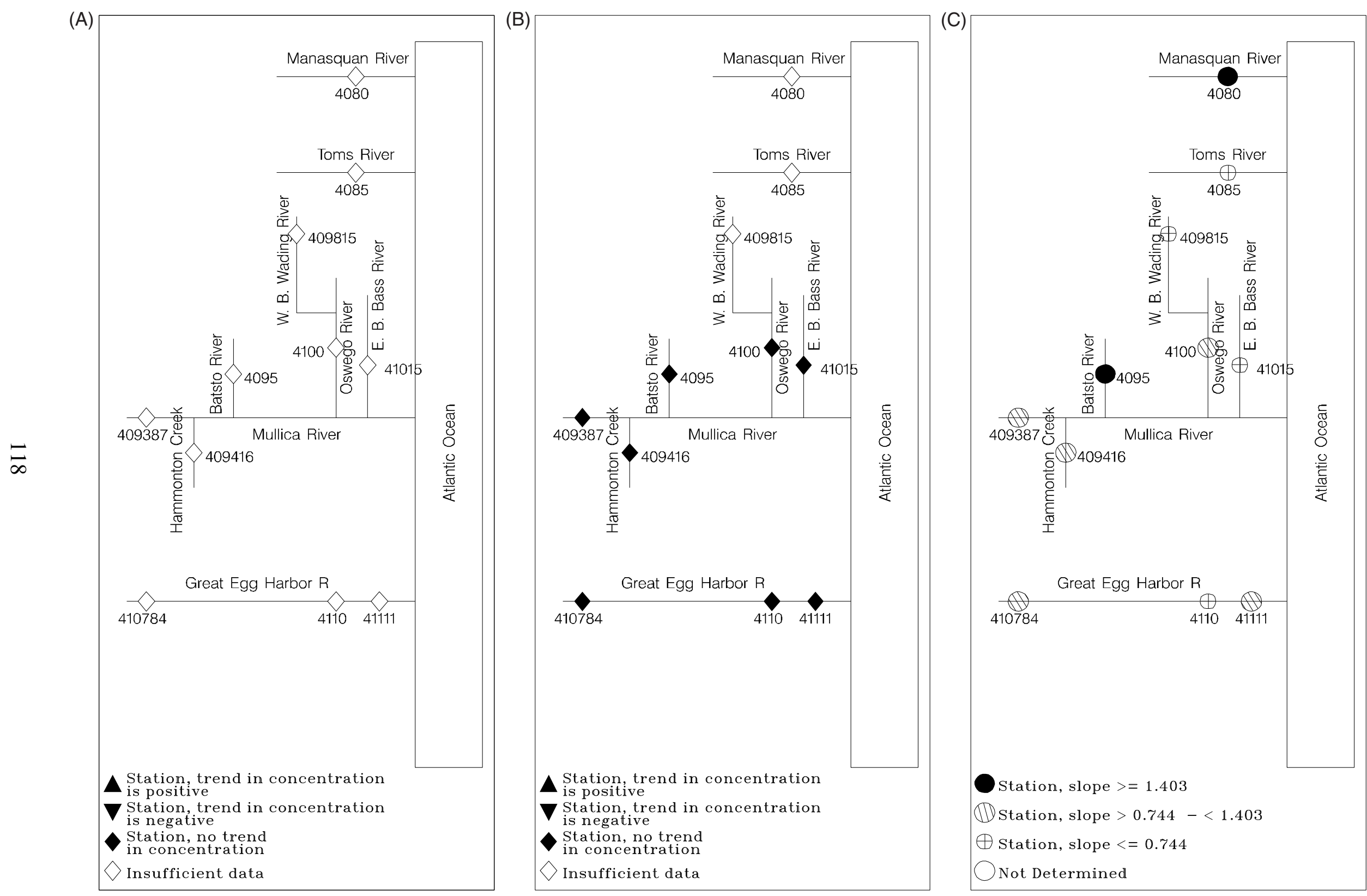

Figure 36. Trends in total ammonia concentrations during (A) high- and (B) low-flow conditions, and (C) relative slope of total ammonia load to streamflow at surface-water-quality stations in the Atlantic Coastal Basins, N.J., water years 1976-93. 

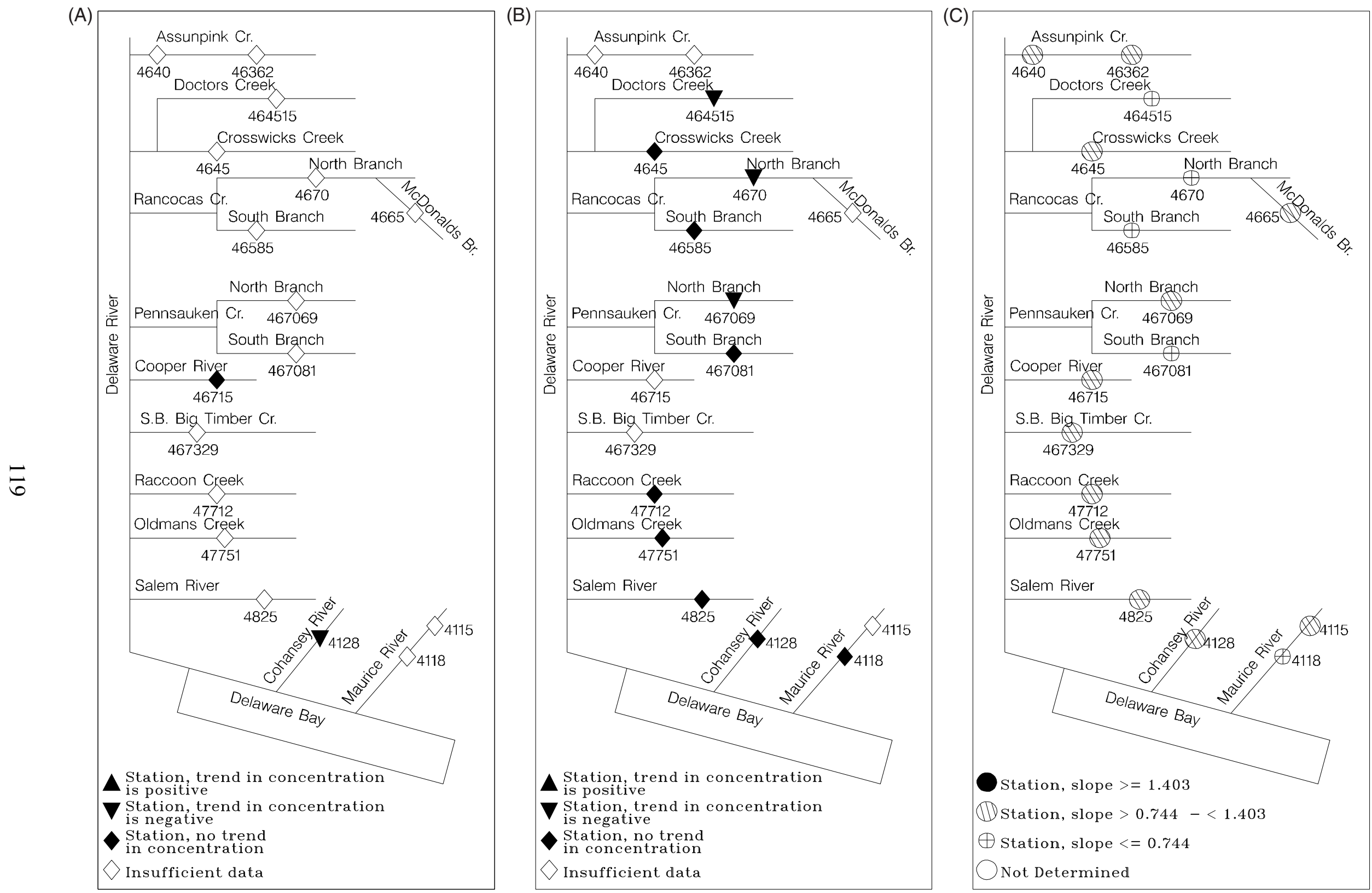

Figure 37. Trends in total ammonia concentrations during (A) high- and (B) low-flow conditions, and (C) relative slope of total ammonia load to streamflow at surface-water-quality stations in the lower Delaware River and Delaware Bay Basins, N.J., water years 1976-93. 


\section{Total Boron}

Boron is a minor constituent in most surface water. Small amounts of boron are essential for plant growth. Boron minerals are present in some igneous rocks; water in volcanic areas and thermal springs may contain considerable concentrations of boron (Hem, 1985). Boron from the cleaning agent, sodium tetraborate (borax), can be present in surface water as a result of the release of treated sewage and industrial-use water.

\section{Relation of trends in concentration to flow conditions}

Insufficient data are available to determine trends in boron concentrations during high and low flows at all stations in the study area (figs. 38a, 39a, 38b, and 39b).

\section{$\underline{\text { Relation of load to streamflow }}$}

The range categories of regression slopes of total boron to streamflow are depicted in figures $38 \mathrm{c}$ and 39c. Sufficient data were not available to determine slopes at 12 of the stations. The slopes range from zero at the downstream station on the Great Egg Harbor River (41111) and the stations on the Crosswicks (4645), Doctors (464515), and Oldmans (47751) Creeks (tables 15a, 18a, 19a, and 28a, respectively) to 1.655 at station 4128 on the Cohansey River (table 30a). Slopes are in the high range at the stations on the Mullica River (309387), North Branch of the Rancocas Creek (4670), and Cohansey River (4128), where the contributions from storm runoff are larger and less influenced by point sources and ground water than at other sites in the study area. All four stations with zero slopes and station 467081 on the South Branch of the Pennsauken Creek have slopes in the low range, indicating that the contributions from constant sources (most likely ground water) are larger and less influenced by storm runoff at these sites than at other sites in the study area.

\section{Total Lead}

Lead is occasionally present in surface water in trace amounts, which can be toxic to aquatic organisms. Lead is widely dispersed in sedimentary rocks; however, its mobility is low (Hem, 1985). The many uses of lead have dispersed the element throughout the environment. Dry fallout and rain-out of particulate lead is probably a factor of major importance in the circulation of the element. Concentrations of lead in rain and snow are greater in areas subject to substantial air pollution than in more remote areas. Storm runoff is a potential source of lead in surface water.

\section{$\underline{\text { Relation of trends in concentration to flow conditions }}$}

Insufficient data are available to determine trends in lead concentrations during high flows at all stations in the study area (figs. 40a and 41a). The trend in total lead concentrations during low flows is negative at the one station on the North Branch of the Pennsauken Creek (467069), indicating a decrease in the contribution from point sources and ground water over time at this site (figs. $40 \mathrm{~b}$ and $41 \mathrm{~b}$ ). 


\section{$\underline{\text { Relation of load to streamflow }}$}

The range categories of regression slopes of total lead to streamflow are depicted in figures 40c and 41c. The slopes range from zero at the stations on the East Branch of the Bass River (41015) and Oldmans Creek (47751), and the downstream station on the Maurice River (4118) (tables 12a, 28a, and 32a, respectively) to 2.942 at station 4645 on the Crosswicks Creek (table 18a). The slope is in the high range only at the one station on the Crosswicks Creek (4645), where the contribution to instream total lead load from storm runoff is larger and less influenced by point sources and ground water than at other sites in the study area. Slopes are in the low range at the stations on the East Branch of the Bass River (41015) and Oldmans Creek (47751), and the downstream station on the Maurice River (4118). At these stations, the contributions to instream total lead loads are less influenced by storm runoff than at other sites in the study area.

\section{Fecal Coliform Bacteria}

Fecal coliform bacteria are present in the intestine and feces of warm-blooded animals. The presence of high numbers of fecal coliform bacteria in surface water can indicate the recent release of untreated wastewater or the presence of animal feces, or both. These organisms also can indicate the presence of pathogens that are harmful to humans. High numbers of fecal coliform bacteria can render surface water unfit for some uses, such as swimming and fishing. Fecal coliform bacteria are often used as indicators of the sanitary quality of the water (Eaton and others, 1995). For laboratory purposes, fecal coliform bacteria are defined as all organisms that produce blue colonies within 24 hours when incubated at $44.5^{\circ} \mathrm{C} \pm 0.2{ }^{\circ} \mathrm{C}$ on $\mathrm{M}$-FC medium (nutrient medium for bacterial growth) (Bauersfeld and others, 1994).

\section{$\underline{\text { Relation of trends in concentration to flow conditions }}$}

The fecal coliform bacteria concentrations during high flows show no trends at the downstream station on the Assunpink Creek (4640) and the stations on the Cooper River (46715), Raccoon Creek (47712), and Cohansey River (4128) (figs. 42a and 43a). The trends of fecal coliform bacteria concentrations during low flows are positive at the stations on the Hammonton Creek (409416), Great Egg Harbor River (4110), and Salem (4825) River, indicating an increase in the contributions from point sources and ground water over time at these sites (figs. 42b and 43b). The fecal coliform bacteria concentrations during low flows show no trends at the stations on the Manasquan (4080), Mullica (409387), Batsto (4095), and Oswego (4100) Rivers, and East Branch of the Bass River (41015); the downstream station on the Great Egg Harbor River (41111); the stations on the Crosswicks Creek (4645), Doctors Creek (464515), South (46585) and North (4670) Branches of the Rancocas Creek, the North (467069) and South (467081) Branches of the Pennsauken Creek, Raccoon Creek (47712), Oldmans Creek (47751), and Cohansey River (4128); and the downstream station on the Maurice River (4118). 

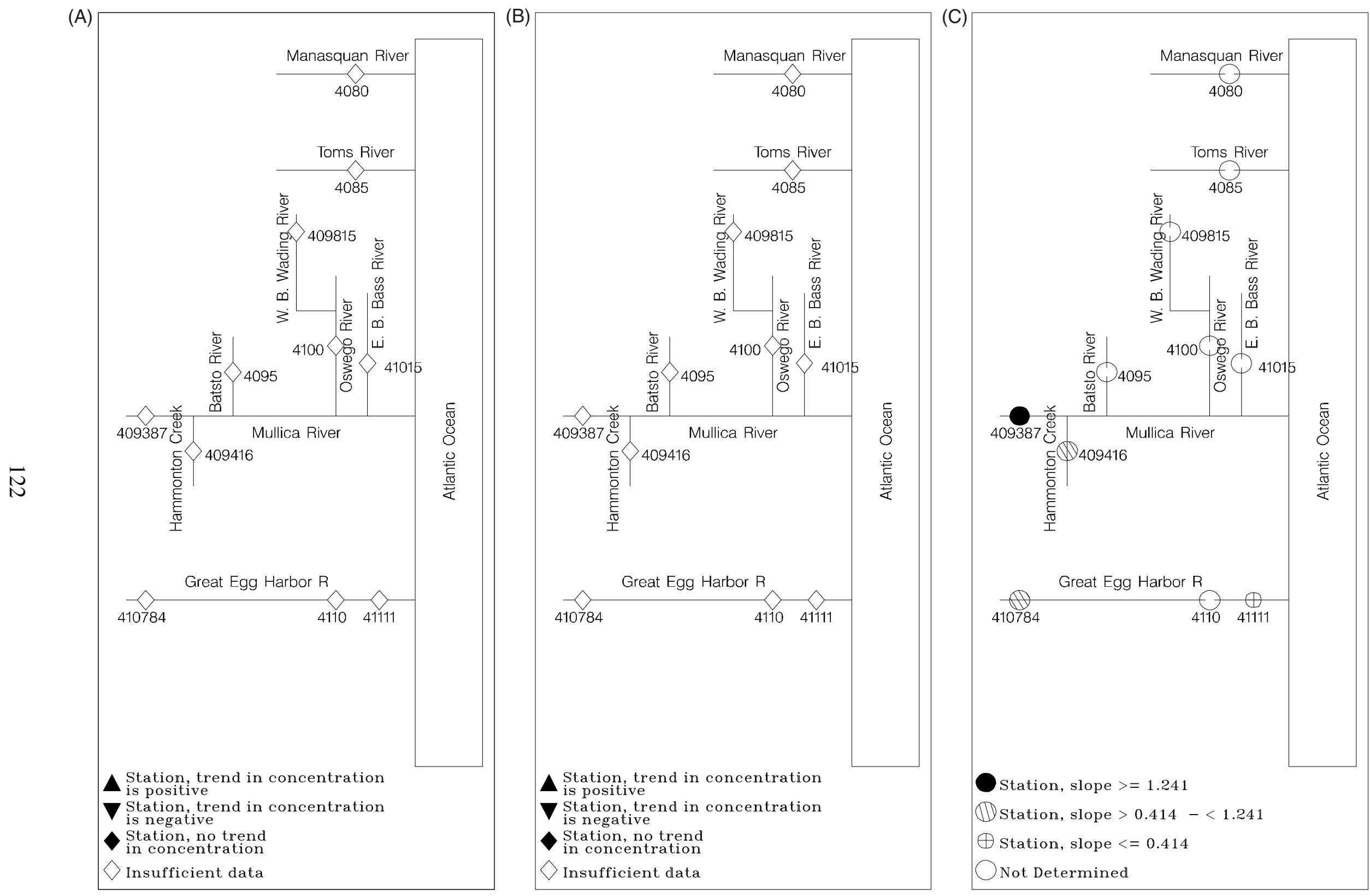

Figure 38. Trends in total boron concentrations during $(A)$ high- and $(B)$ low-flow conditions, and $(C)$ relative slope of total boron load to streamflow at surface-water-quality stations in the Atlantic Coastal Basins, N.J., water years 1976-93. 

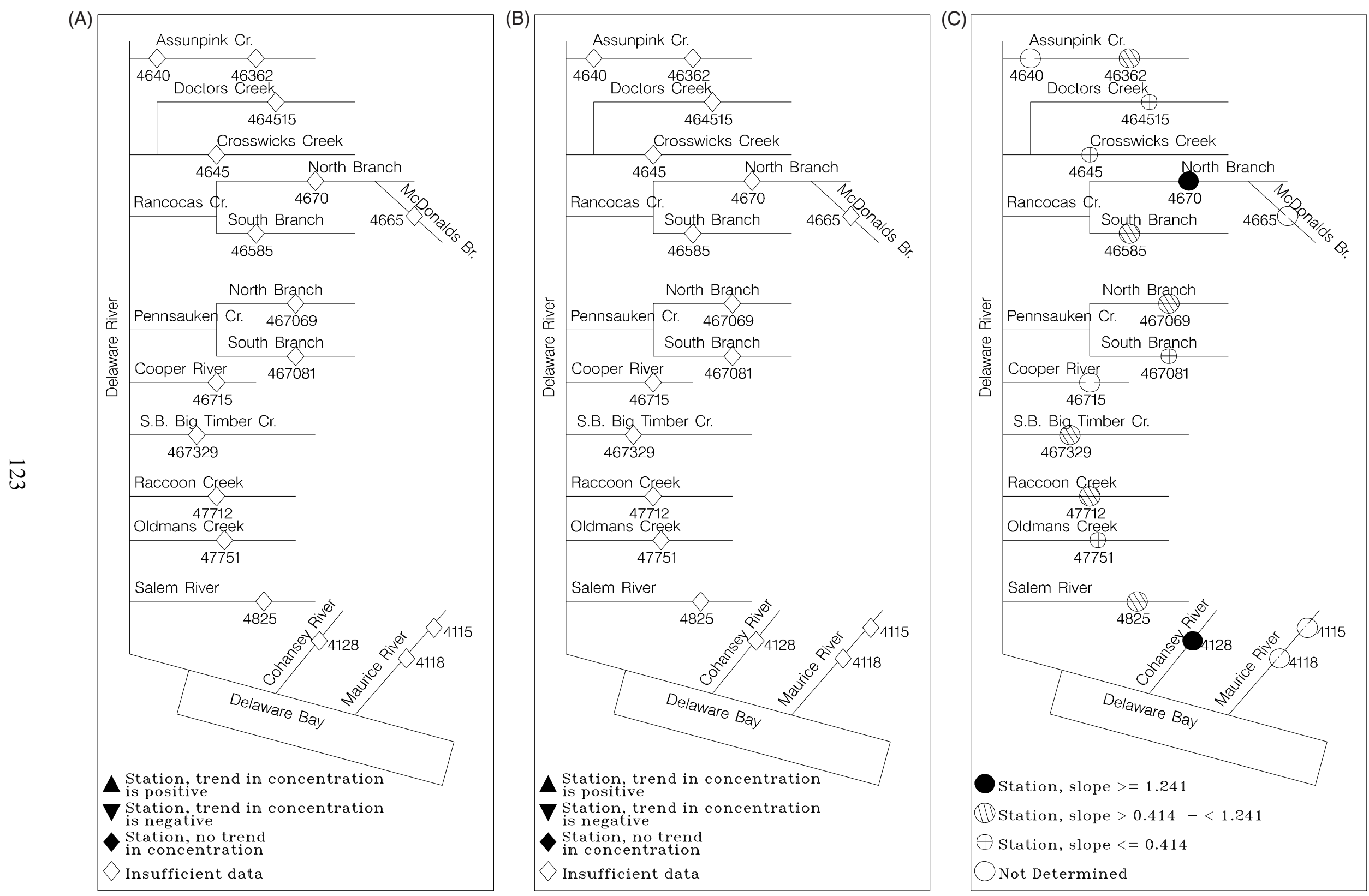

Figure 39. Trends in total boron concentrations during (A) high- and (B) low-flow conditions, and (C) relative slope of total boron load to streamflow at surface-water-quality stations in the lower Delaware River and Delaware Bay Basins, N.J., water years 1976-93. 

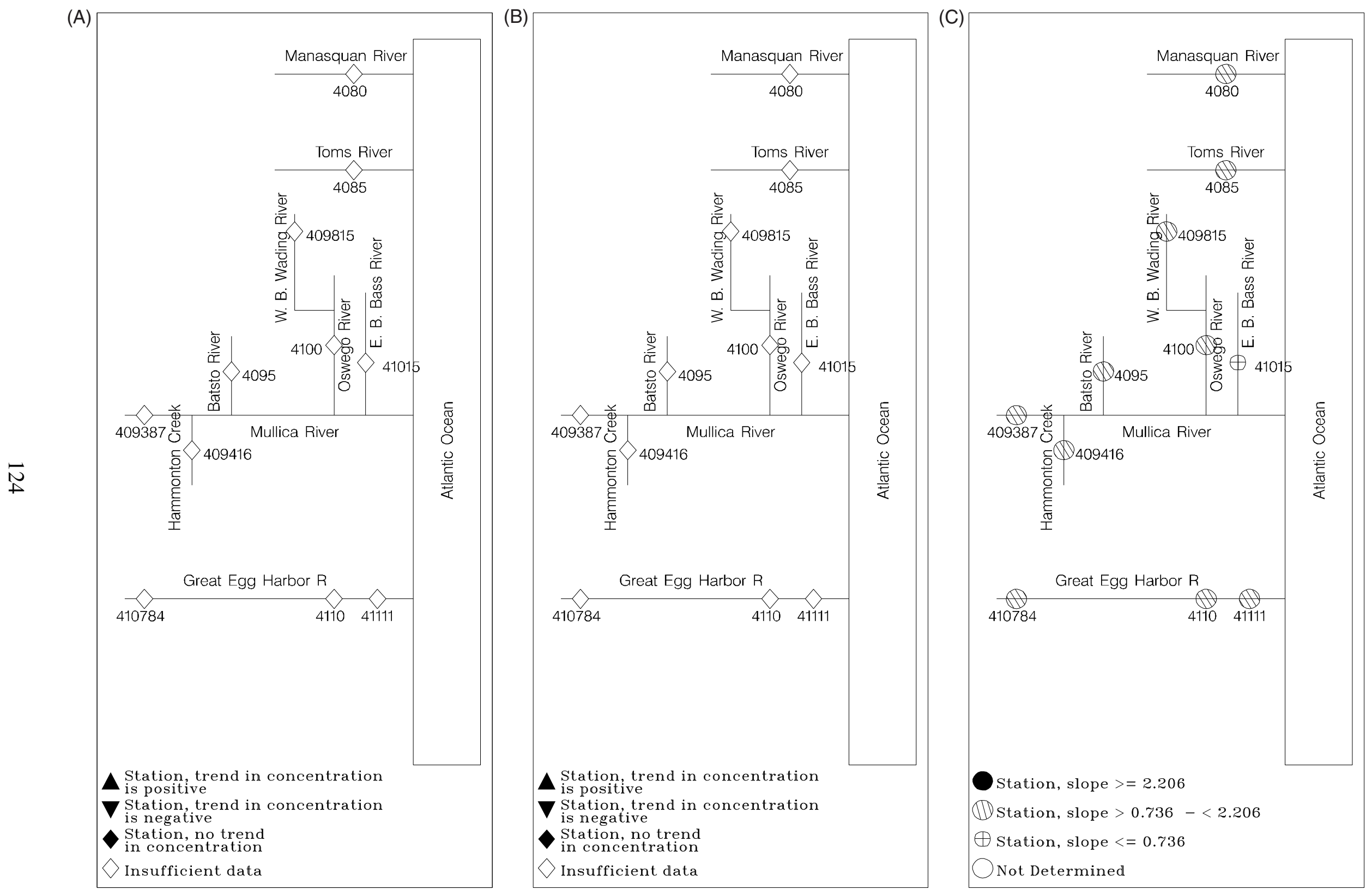

Figure 40. Trends in total lead concentrations during (A) high- and (B) low-flow conditions, and (C) relative slope of total lead load to streamflow at surface-water-quality stations in the Atlantic Coastal Basins, N.J., water years 1976-93. 

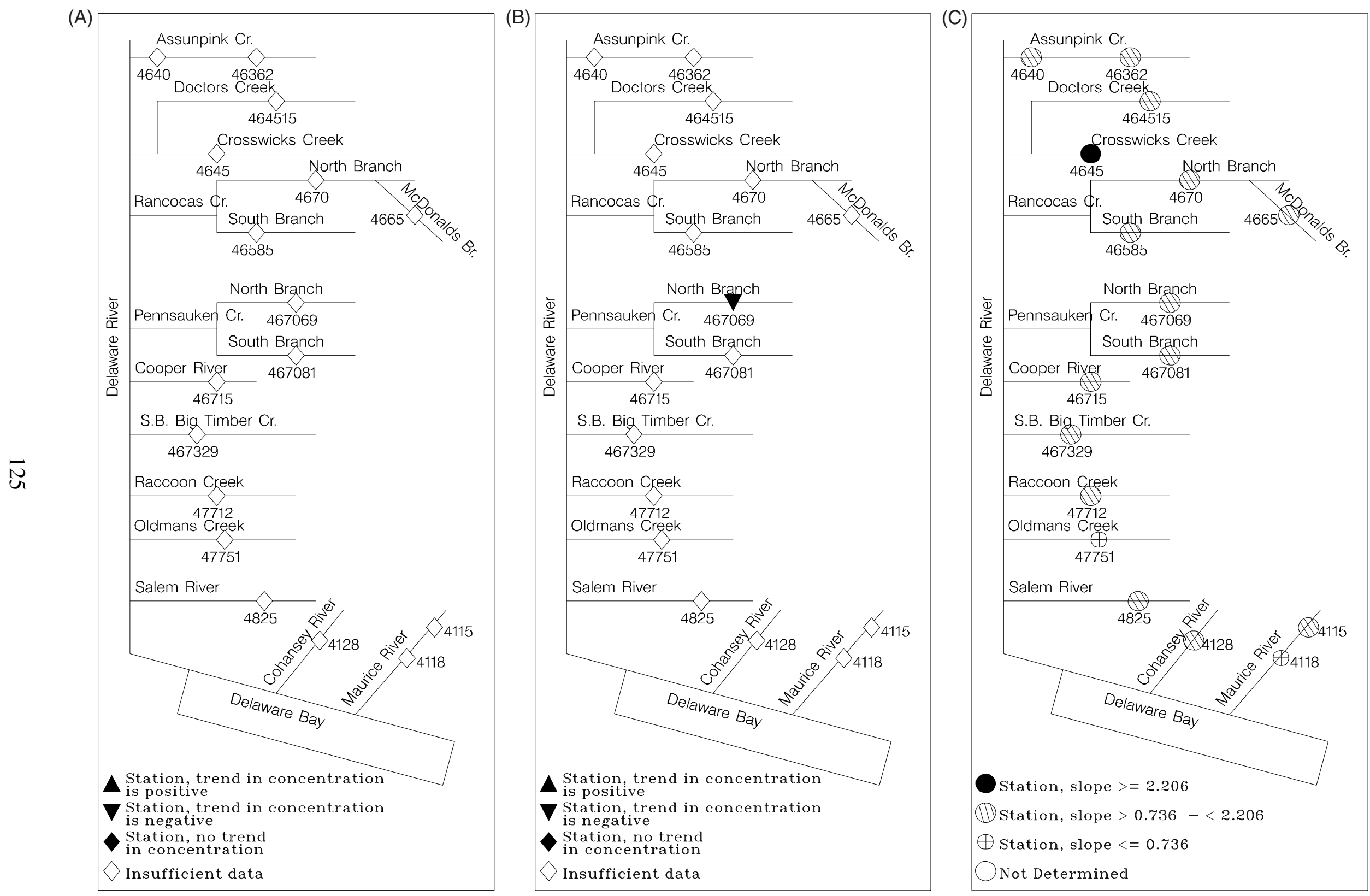

Figure 41. Trends in total lead concentrations during (A) high- and (B) low-flow conditions, and (C) relative slope of total lead load to streamflow at surface-water-quality stations in the lower Delaware River and Delaware Bay Basins, N.J., water years 1976-93. 

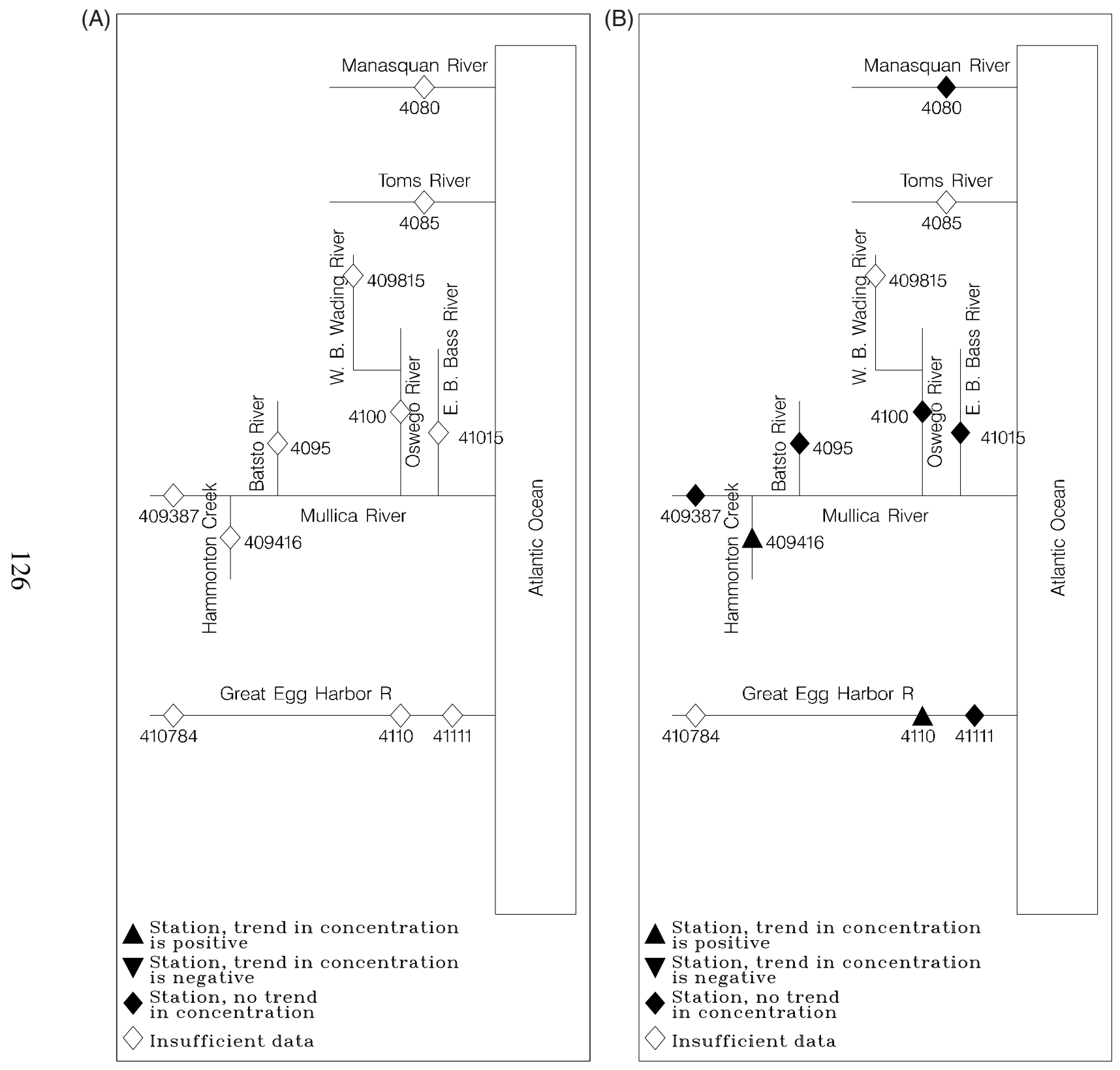

Figure 42. Trends in fecal coliform bacteria concentrations during (A) high- and (B) low-flow conditions at surface-water-quality stations in the Atlantic Coastal Basins, N.J., water years 1976-93. 

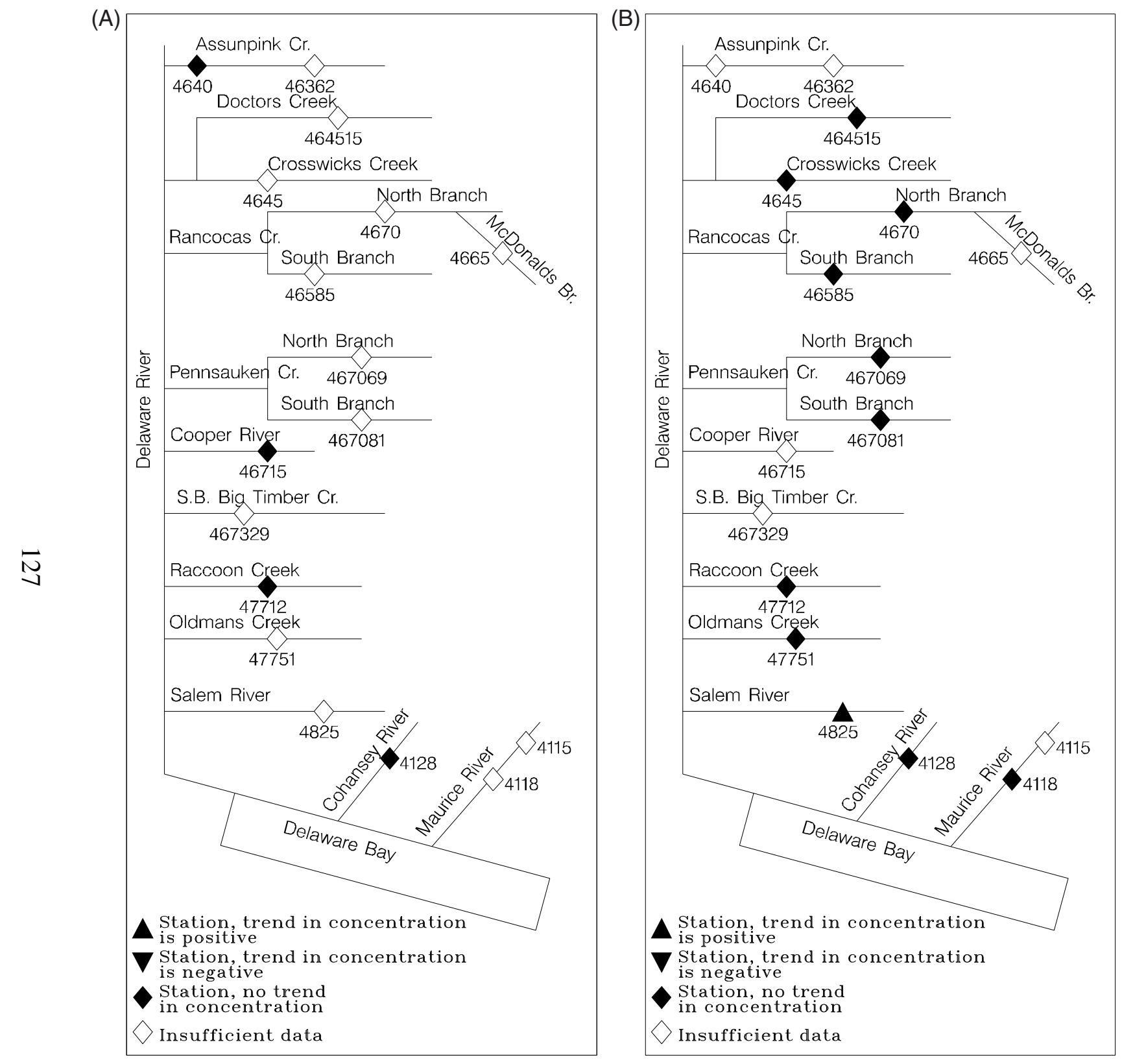

Figure 43. Trends in fecal coliform bacteria concentrations during (A) high- and (B) low-flow conditions at surface-water-quality stations in the lower Delaware River and Delaware Bay Basins, N.J., water years 1976-93. 


\section{COMPARISON OF RESULTS}

In the Atlantic Coastal Basins, positive trends in constituent concentrations over time during low flows indicate increasing constant-rate source contributions for NA at two stations, for CL at two stations, for DO at one station, for FDO at one station, and for BACT at two stations (table 33). In the lower Delaware River and Delaware Bay Basins, increasing constant-rate contributions are indicated for HARD at two stations, for NA at four stations, for CL at seven stations, for DO at one station, for FDO at one station, for NO32 at one station, and for BACT at one station (table 34).

In the Atlantic Coastal Basins, negative trends indicate decreasing constant-rate source contributions for NA at two stations, for CL at two stations, for FDO at one station, for TP at one station, for NO32 at one station, for NO2 at one station, and for TAON at four stations (table 33). In the lower Delaware River and Delaware Bay Basins, decreasing constant-rate contributions are indicated for TOC at one station, for NA at two stations, for CL at one station, for FDO at two stations, for TN at two stations, for NO32 at one station, for TAON at three stations, for NH4 at three stations, and for PB at one station (table 34).

Positive trends during high flows indicate increasing intermittent-source contributions for $\mathrm{CL}$ at one station in the Atlantic Coastal Basins (table 35). Increasing intermittent-source contributions are also indicated for HARD at one station and for DS, NA, and CL at one station in the lower Delaware River and Delaware Bay Basins, respectively (table 36). Negative trends during high flows indicate decreasing intermittent-source contributions for HARD and TP at one station in the Atlantic Coastal Basins (table 35). In the lower Delaware River and Delaware Bay Basins, decreasing intermittent-source contributions are indicated for DS at one station, for TP at one station, for TN at one station, for NO2 at two stations, for TAON at one station, and for NH4 at one station (table 36).

All water-quality stations in the Atlantic Coastal Basin and 12 stations in the lower Delaware River and Delaware Bay Basins have sufficient data to determine trends during low flows, but only 1 station in the Atlantic Coastal Basin and 5 stations in the lower Delaware River and Delaware Bay Basins have sufficient data to determine trends during high flows. The upstream station on the Assunpink Creek (46362) and the one station on the South Branch Big Timber Creek (467329) have insufficient data to determine trends during both high and low flows. The lack of water-quality data during low and high flows at many of the stations is due, in part, to the conservative method used in this study. This method ensured that only data collected during base flow and stormflow were used to determine trends. If additional data were collected or the data-collection schedule were changed to accommodate sampling during a full range of flow conditions, and if different flow durations were used to group the data so that more of the data were included, a greater number of significant trends might be identified. All figures generated in this study are available in appendixes on CD-ROM for further site-by-site comparisons of visual trends.

Relations of concentration to streamflow show that at most stations, concentrations decrease with increasing flows (dilution); therefore, negative concentration slopes predominate. Streams such as Batsto River and McDonalds Branch, which have very few or no point source discharges and which are dominated by ground-water discharge (more than 75 percent of annual 
streamflow is base flow), generally have small concentrations, positive concentration-slope values, and large (greater than 1.0) load-slope values. For such streams, the contributions to instream load from storm runoff is large (tables 9 and 21). Storm runoff is composed of overland runoff and interflow which can contain displaced shallow ground water and water from nearby wetlands.

Significant seasonal dependency (14 or more stations) is evident for HARD, TOC, NA, DO, FDO, TP, TN, NO32, NO2, and BACT (tables 37 and 38). Seasonal dependency is not evident at any station for B and only at station 4085 on the Toms River for PB. DO shows seasonal dependency at all stations, possibly because of its relation to bioactivity in surface water. NA and HARD most likely show seasonal dependency because of road salting; however, DS, which includes the ions sodium, calcium, and magnesium, shows seasonal dependency at only seven stations.

A similar study was conducted in the Hackensack, Passaic, Elizabeth, and Rahway River Basins. Buxton and others (1998) found that the minimum load-to-streamflow slopes for ALK, HARD, TOC, DS, NA, and CL in those basins ranged from 0.56 to 0.81 , and the maximum load slopes ranged from 0.92 to 1.22 . SS had the highest minimum load slope of 0.85 and the highest maximum load slope of 1.92. For the six nutrient species, minimum load slopes ranged from 0.00 to 0.55 , and maximum load slopes ranged from 1.11 to 1.24 . The spread between the minimum and maximum load slopes is smaller and the slopes tend to be of a lower magnitude for most constituents compared to those for the Atlantic Coastal, lower Delaware River, and Delaware Bay Basins. The slopes in the Atlantic Coastal, lower Delaware River, and Delaware Bay Basins, in general, are greater than the slopes in the Hackensack, Passaic, Elizabeth, and Rahway River Basins, indicating the greater relative importance of contributions from intermittent sources (storm runoff) than from constant sources (point sources and ground water) in the ground-waterdominated system.

Load slopes are in the low range for eight constituents at station 4640 on the Assunpink Creek, for seven at the stations on the Hammonton Creek (409416) and South Branch of the Pennsauken Creek (467081), and for five at station 4085 on the Toms River; all other stations have four or less constituents with slopes in the low range. No load slopes are in the low range for stations on the Oswego (4100) and Cooper (46715) Rivers, and South Branch Big Timber Creek (456329). Load slopes are in the high range for six constituents at station 4095 on the Batsto River; all other stations have four or less constituents with slopes in the high range. Stations with no load slopes in the high range are on the Toms River (4085), Great Egg Harbor River (410784), Assunpink Creek (4640), South Branches of the Rancocas (46585) and Pennsauken (467081) Creeks, and Maurice River (4118).

Load slopes for each constituent can be compared at stations along the Great Egg Harbor River, Assunpink Creek, and Maurice River. The magnitude of the load slopes for HARD, TP, TN, NO2, and TAON increases along the Great Egg Harbor River, indicating an increase in the relative influence of contributions from intermittent sources (storm runoff) along the river; the period-of-record medians for these constituents decreases along the river. The magnitude of the load slopes for ALK, HARD, DS, NA, CL, TP, TN, NO32, NO2, TAON, and NH4 decreases along the Assunpink Creek, indicating a decrease in the relative influence of contributions from storm runoff along the river. The magnitude of the load slopes for TOC, NA, CL, TAON, and NH4 decreases along the Maurice River, also indicating a decrease in the relative influence of contributions from storm runoff along the river. 
Table 33. Concentration trends during low flow at surface-water-quality stations in the Atlantic Coastal Basins, N.J., water years 1976-93

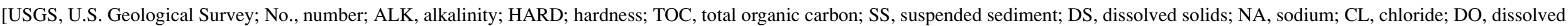

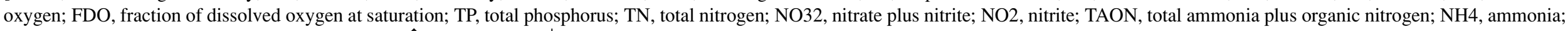
B, boron, PB, lead; BACT, fecal-coliform bacteria; $\uparrow$, positive trend; $\downarrow$, negative trend; $\leftrightarrow$, no trend (slope is not significant at the 0.05 level); -, insufficient data for analysis; --, no total]

\begin{tabular}{|c|c|c|c|c|c|c|c|c|c|c|c|c|c|c|c|c|c|c|c|c|c|c|}
\hline River basin & $\begin{array}{l}\text { USGS station } \\
\text { number }\end{array}$ & ALK & HARD & TOC & SS & DS & NA & $\mathrm{CL}$ & DO & FDO & ТP & $\mathrm{TN}$ & NO32 & $\mathrm{NO} 2$ & TAON & $\mathrm{NH} 4$ & B & PB & BACT & $\begin{array}{l}\text { No. of con- } \\
\text { stituents } \\
\text { with a posi- } \\
\text { tive trend }\end{array}$ & $\begin{array}{l}\text { No. of con- } \\
\text { stituents } \\
\text { with a neg- } \\
\text { ative trend }\end{array}$ & $\begin{array}{l}\text { No. of con- } \\
\text { stituents } \\
\text { with no } \\
\text { trend }\end{array}$ \\
\hline Manasquan & 01408000 & - & - & - & - & - & - & - & $\uparrow$ & $\uparrow$ & - & - & - & - & $\downarrow$ & - & - & - & $\leftrightarrow$ & 2 & 1 & 1 \\
\hline Toms & 01408500 & - & $\leftrightarrow$ & - & $\leftrightarrow$ & $\leftrightarrow$ & $\uparrow$ & $\uparrow$ & $\leftrightarrow$ & $\leftrightarrow$ & $\downarrow$ & $\leftrightarrow$ & $\leftrightarrow$ & - & $\leftrightarrow$ & - & - & - & - & 2 & 1 & 8 \\
\hline Mullica & 01409387 & - & - & $\leftrightarrow$ & - & - & $\leftrightarrow$ & - & $\leftrightarrow$ & $\leftrightarrow$ & - & $\leftrightarrow$ & $\leftrightarrow$ & - & $\leftrightarrow$ & $\leftrightarrow$ & - & - & $\leftrightarrow$ & 0 & 0 & 9 \\
\hline Hammonton & 01409416 & - & $\leftrightarrow$ & $\leftrightarrow$ & - & $\leftrightarrow$ & $\leftrightarrow$ & $\leftrightarrow$ & $\leftrightarrow$ & $\leftrightarrow$ & - & $\leftrightarrow$ & $\leftrightarrow$ & - & $\leftrightarrow$ & $\leftrightarrow$ & - & - & $\uparrow$ & 1 & 0 & 11 \\
\hline Batsto & 01409500 & - & $\leftrightarrow$ & $\leftrightarrow$ & - & $\leftrightarrow$ & $\leftrightarrow$ & $\leftrightarrow$ & $\leftrightarrow$ & $\leftrightarrow$ & - & $\leftrightarrow$ & $\leftrightarrow$ & $\downarrow$ & $\leftrightarrow$ & $\leftrightarrow$ & - & - & $\leftrightarrow$ & 0 & 1 & 12 \\
\hline West Branch Wading & 01409815 & - & $\leftrightarrow$ & - & - & $\leftrightarrow$ & $\uparrow$ & $\uparrow$ & $\leftrightarrow$ & $\leftrightarrow$ & $\leftrightarrow$ & - & - & - & $\leftrightarrow$ & - & - & - & - & 2 & 0 & 6 \\
\hline Oswego & 01410000 & - & $\leftrightarrow$ & $\leftrightarrow$ & - & $\leftrightarrow$ & $\leftrightarrow$ & - & $\leftrightarrow$ & $\leftrightarrow$ & - & $\leftrightarrow$ & $\leftrightarrow$ & - & $\downarrow$ & $\leftrightarrow$ & - & - & $\leftrightarrow$ & 0 & 1 & 10 \\
\hline East Branch Bass & 01410150 & - & $\leftrightarrow$ & $\leftrightarrow$ & - & $\leftrightarrow$ & $\leftrightarrow$ & $\leftrightarrow$ & $\leftrightarrow$ & $\leftrightarrow$ & - & $\leftrightarrow$ & $\leftrightarrow$ & - & $\leftrightarrow$ & $\leftrightarrow$ & - & - & $\leftrightarrow$ & 0 & 0 & 12 \\
\hline \multirow[t]{3}{*}{ Great Egg Harbor } & 01410784 & - & - & $\leftrightarrow$ & - & - & - & - & $\leftrightarrow$ & $\leftrightarrow$ & - & $\leftrightarrow$ & $\downarrow$ & - & $\leftrightarrow$ & $\leftrightarrow$ & - & - & - & 0 & 1 & 6 \\
\hline & 01411000 & - & $\leftrightarrow$ & - & - & - & $\downarrow$ & $\downarrow$ & $\leftrightarrow$ & $\leftrightarrow$ & - & $\leftrightarrow$ & $\leftrightarrow$ & $\leftrightarrow$ & $\downarrow$ & $\leftrightarrow$ & - & - & $\uparrow$ & 1 & 3 & 7 \\
\hline & 01411110 & - & $\leftrightarrow$ & $\leftrightarrow$ & - & $\leftrightarrow$ & $\downarrow$ & $\downarrow$ & $\leftrightarrow$ & $\downarrow$ & - & $\leftrightarrow$ & $\leftrightarrow$ & - & $\downarrow$ & $\leftrightarrow$ & - & - & $\leftrightarrow$ & 0 & 4 & 8 \\
\hline \multicolumn{2}{|c|}{ No. of stations with a positive trend } & 0 & 0 & 0 & 0 & 0 & 2 & 2 & 1 & 1 & 0 & 0 & 0 & 0 & 0 & 0 & 0 & 0 & 2 & -- & -- & -- \\
\hline \multicolumn{2}{|c|}{ No. of stations with a negative trend } & 0 & 0 & 0 & 0 & 0 & 2 & 2 & 0 & 1 & 1 & 0 & 1 & 1 & 4 & 0 & 0 & 0 & 0 & -- & -- & -- \\
\hline \multicolumn{2}{|c|}{ No. of stations with no trend } & 0 & 8 & 7 & 1 & 7 & 5 & 3 & 10 & 9 & 1 & 9 & 8 & 1 & 7 & 8 & 0 & 0 & 6 & -- & -- & -- \\
\hline
\end{tabular}


Table 34. Concentration trends during low flow at surface-water-quality stations in the lower Delaware River and Delaware Bay Basins, N.J., water years 1976-93

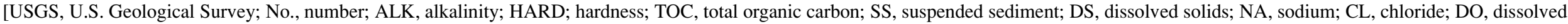

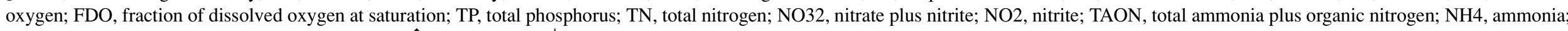
B, boron, PB, lead; BACT, fecal-coliform bacteria; $\uparrow$, positive trend; $\downarrow$, negative trend; $\leftrightarrow$, no trend (slope is not significant at the 0.05 level); -, insufficient data for analysis; --, no total]

\begin{tabular}{|c|c|c|c|c|c|c|c|c|c|c|c|c|c|c|c|c|c|c|c|c|c|c|}
\hline River basin & $\begin{array}{l}\text { USGS station } \\
\text { number }\end{array}$ & ALK & HARD & TOC & SS & DS & NA & $\mathrm{CL}$ & DO & FDO & $\mathrm{TP}$ & $\mathrm{TN}$ & NO32 & $\mathrm{NO} 2$ & TAON & NH4 & B & PB & BACT & $\begin{array}{l}\text { No. of con- } \\
\text { stituents } \\
\text { with a posi- } \\
\text { tive trend }\end{array}$ & $\begin{array}{l}\text { No. of con- } \\
\text { stituents } \\
\text {-with a nega- } \\
\text { tive trend }\end{array}$ & $\begin{array}{c}\text { No. of con- } \\
\text { stituents } \\
\text { with no } \\
\text { trend }\end{array}$ \\
\hline \multirow[t]{2}{*}{ Assunpink } & 01463620 & - & - & - & - & - & - & - & - & - & - & - & - & - & - & - & - & - & - & 0 & 0 & 0 \\
\hline & 01464000 & - & - & - & - & - & - & - & - & - & - & - & - & - & - & - & - & - & - & 0 & 0 & 0 \\
\hline Crosswicks & 01464500 & - & $\leftrightarrow$ & $\leftrightarrow$ & - & $\leftrightarrow$ & $\leftrightarrow$ & $\uparrow$ & $\leftrightarrow$ & $\leftrightarrow$ & - & $\leftrightarrow$ & $\leftrightarrow$ & - & $\downarrow$ & $\leftrightarrow$ & - & - & $\leftrightarrow$ & 1 & 1 & 10 \\
\hline Doctors & 01464515 & - & $\leftrightarrow$ & $\leftrightarrow$ & - & $\leftrightarrow$ & $\uparrow$ & $\leftrightarrow$ & $\leftrightarrow$ & $\leftrightarrow$ & - & $\leftrightarrow$ & $\leftrightarrow$ & - & $\leftrightarrow$ & $\downarrow$ & - & - & $\leftrightarrow$ & 1 & 1 & 10 \\
\hline South Branch Rancocas & 01465850 & - & $\leftrightarrow$ & $\leftrightarrow$ & - & $\leftrightarrow$ & $\leftrightarrow$ & $\uparrow$ & $\leftrightarrow$ & $\downarrow$ & - & $\leftrightarrow$ & $\uparrow$ & - & $\leftrightarrow$ & $\leftrightarrow$ & - & - & $\leftrightarrow$ & 2 & 1 & 9 \\
\hline McDonalds & 01466500 & - & $\leftrightarrow$ & - & $\leftrightarrow$ & $\leftrightarrow$ & $\leftrightarrow$ & $\leftrightarrow$ & $\leftrightarrow$ & $\leftrightarrow$ & $\leftrightarrow$ & - & $\leftrightarrow$ & - & - & - & - & - & - & 0 & 0 & 9 \\
\hline North Branch Rancocas & 01467000 & - & $\leftrightarrow$ & $\leftrightarrow$ & - & $\leftrightarrow$ & $\uparrow$ & $\uparrow$ & $\leftrightarrow$ & $\leftrightarrow$ & - & $\leftrightarrow$ & $\leftrightarrow$ & - & $\downarrow$ & $\downarrow$ & - & - & $\leftrightarrow$ & 2 & 2 & 8 \\
\hline North Branch Pennsauken & 01467069 & - & $\leftrightarrow$ & $\leftrightarrow$ & - & $\leftrightarrow$ & $\downarrow$ & $\leftrightarrow$ & $\uparrow$ & $\leftrightarrow$ & - & $\downarrow$ & $\downarrow$ & - & $\downarrow$ & $\downarrow$ & - & $\downarrow$ & $\leftrightarrow$ & 1 & 6 & 6 \\
\hline South Branch Pennsauken & 01467081 & - & $\uparrow$ & $\leftrightarrow$ & - & $\leftrightarrow$ & $\leftrightarrow$ & $\uparrow$ & $\leftrightarrow$ & $\leftrightarrow$ & - & $\downarrow$ & $\leftrightarrow$ & - & $\leftrightarrow$ & $\leftrightarrow$ & - & - & $\leftrightarrow$ & 2 & 1 & 9 \\
\hline Cooper & 01467150 & - & - & - & - & - & - & - & - & - & - & - & - & - & - & - & - & - & - & 0 & 0 & 0 \\
\hline South Branch Big Timber & 01467329 & - & - & - & - & - & - & - & - & - & - & - & - & - & - & - & - & - & - & 0 & 0 & 0 \\
\hline Raccoon & 01477120 & - & $\leftrightarrow$ & $\downarrow$ & - & - & $\leftrightarrow$ & $\uparrow$ & $\leftrightarrow$ & $\downarrow$ & $\leftrightarrow$ & $\leftrightarrow$ & $\leftrightarrow$ & - & $\leftrightarrow$ & $\leftrightarrow$ & - & - & $\leftrightarrow$ & 1 & 2 & 9 \\
\hline Oldmans & 01477510 & - & $\leftrightarrow$ & $\leftrightarrow$ & - & $\leftrightarrow$ & $\uparrow$ & $\leftrightarrow$ & $\leftrightarrow$ & $\uparrow$ & - & $\leftrightarrow$ & $\leftrightarrow$ & - & $\leftrightarrow$ & $\leftrightarrow$ & - & - & $\leftrightarrow$ & 2 & 0 & 10 \\
\hline Salem & 01482500 & - & $\leftrightarrow$ & $\leftrightarrow$ & - & $\leftrightarrow$ & $\uparrow$ & $\uparrow$ & $\leftrightarrow$ & $\leftrightarrow$ & - & $\leftrightarrow$ & $\leftrightarrow$ & - & $\leftrightarrow$ & $\leftrightarrow$ & - & - & $\uparrow$ & 3 & 0 & 9 \\
\hline Cohansey & 01412800 & - & $\leftrightarrow$ & $\leftrightarrow$ & - & $\leftrightarrow$ & $\leftrightarrow$ & $\downarrow$ & $\leftrightarrow$ & $\leftrightarrow$ & - & $\leftrightarrow$ & $\leftrightarrow$ & - & $\leftrightarrow$ & $\leftrightarrow$ & - & - & $\leftrightarrow$ & 0 & 1 & 11 \\
\hline \multirow[t]{2}{*}{ Maurice } & 01411500 & - & $\uparrow$ & - & - & $\leftrightarrow$ & $\downarrow$ & $\uparrow$ & $\leftrightarrow$ & $\leftrightarrow$ & $\leftrightarrow$ & $\leftrightarrow$ & $\leftrightarrow$ & - & $\leftrightarrow$ & - & - & - & - & 2 & 1 & 7 \\
\hline & 01411800 & - & - & - & - & - & - & - & $\leftrightarrow$ & $\leftrightarrow$ & - & $\leftrightarrow$ & $\leftrightarrow$ & $\leftrightarrow$ & $\leftrightarrow$ & $\leftrightarrow$ & - & - & $\leftrightarrow$ & 0 & 0 & 8 \\
\hline \multicolumn{2}{|c|}{ No. of stations with a positive trend } & 0 & 2 & 0 & 0 & 0 & 4 & 7 & 1 & 1 & 0 & 0 & 1 & 0 & 0 & 0 & 0 & 0 & 1 & -- & -- & -- \\
\hline \multicolumn{2}{|c|}{ No. of stations with a negative trend } & 0 & 0 & 1 & 0 & 0 & 2 & 1 & 0 & 2 & 0 & 2 & 1 & 0 & 3 & 3 & 0 & 1 & 0 & -- & -- & -- \\
\hline \multicolumn{2}{|l|}{ No. of stations with no trend } & 0 & 10 & 9 & 1 & 11 & 6 & 4 & 12 & 10 & 3 & 10 & 11 & 1 & 9 & 8 & 0 & 0 & 10 & -- & -- & -- \\
\hline
\end{tabular}


Table 35. Concentration trends during high flow at surface-water-quality stations in the Atlantic Coastal Basins, N.J., water years 1976-93

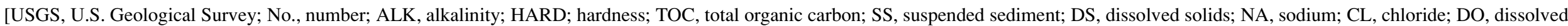

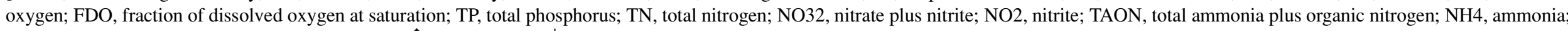
B, boron, PB, lead; BACT, fecal-coliform bacteria; $\uparrow$, positive trend; $\downarrow$, negative trend; $\leftrightarrow$, no trend (slope is not significant at the 0.05 level); -, insufficient data for analysis; --, no total]

\begin{tabular}{|c|c|c|c|c|c|c|c|c|c|c|c|c|c|c|c|c|c|c|c|c|c|c|}
\hline River basin & $\begin{array}{l}\text { USGS station } \\
\text { number }\end{array}$ & ALK & HARD & TOC & SS & DS & NA & $\mathrm{CL}$ & DO & FDO & TP & $\mathrm{TN}$ & NO32 & $\mathrm{NO} 2$ & TAON & NH4 & B & PB & BACT & $\begin{array}{l}\text { No. of con- } \\
\text { stituents } \\
\text { with a posi- } \\
\text { tive trend }\end{array}$ & $\begin{array}{l}\text { No. of con- } \\
\text { stituents } \\
\text { with a neg- } \\
\text { ative trend }\end{array}$ & $\begin{array}{l}\text { No. of con- } \\
\text { stituents } \\
\text { with no } \\
\text { trend }\end{array}$ \\
\hline Manasquan & 01408000 & - & - & - & - & - & - & - & - & - & - & - & - & - & - & - & - & - & - & 0 & 0 & 0 \\
\hline Toms & 01408500 & - & $\downarrow$ & - & $\leftrightarrow$ & $\leftrightarrow$ & $\leftrightarrow$ & $\uparrow$ & $\leftrightarrow$ & $\leftrightarrow$ & $\downarrow$ & $\leftrightarrow$ & $\leftrightarrow$ & - & $\leftrightarrow$ & - & - & - & - & 1 & 2 & 8 \\
\hline Mullica & 01409387 & - & - & - & - & - & - & - & - & - & - & - & - & - & - & - & - & - & - & 0 & 0 & 0 \\
\hline Hammonton & 01409416 & - & - & - & - & - & - & - & - & - & - & - & - & - & - & - & - & - & - & 0 & 0 & 0 \\
\hline Batsto & 01409500 & - & - & - & - & - & - & - & - & - & - & - & - & - & - & - & - & - & - & 0 & 0 & 0 \\
\hline West Branch Wading & 01409815 & - & - & - & - & - & - & - & - & - & - & - & - & - & - & - & - & - & - & 0 & 0 & 0 \\
\hline Oswego & 01410000 & - & - & - & - & - & - & - & - & - & - & - & - & - & - & - & - & - & - & 0 & 0 & 0 \\
\hline East Branch Bass & 01410150 & - & - & - & - & - & - & - & - & - & - & - & - & - & - & - & - & - & - & 0 & 0 & 0 \\
\hline \multirow[t]{3}{*}{ Great Egg Harbor } & 01410784 & - & - & - & - & - & - & - & - & - & - & - & - & - & - & - & - & - & - & 0 & 0 & 0 \\
\hline & 01411000 & - & - & - & - & - & - & - & - & - & - & - & - & - & - & - & - & - & - & 0 & 0 & 0 \\
\hline & 01411110 & - & - & - & - & - & - & - & - & - & - & - & - & - & - & - & - & - & - & 0 & 0 & 0 \\
\hline \multicolumn{2}{|c|}{ No. of stations with a positive trend } & 0 & 0 & 0 & 0 & 0 & 0 & 1 & 0 & 0 & 0 & 0 & 0 & 0 & 0 & 0 & 0 & 0 & 0 & -- & -- & -- \\
\hline \multicolumn{2}{|c|}{ No. of stations with a negative trend } & 0 & 1 & 0 & 0 & 0 & 0 & 0 & 0 & 0 & 1 & 0 & 0 & 0 & 0 & 0 & 0 & 0 & 0 & -- & -- & -- \\
\hline \multicolumn{2}{|c|}{ No. of stations with no trend } & 0 & 0 & 0 & 1 & 1 & 1 & 0 & 1 & 1 & 0 & 1 & 1 & 0 & 1 & 0 & 0 & 0 & 0 & -- & -- & -- \\
\hline
\end{tabular}


Table 36. Concentration trends during high flow at surface-water-quality stations in the lower Delaware River and Delaware Bay Basins, N.J., water years 1976-93

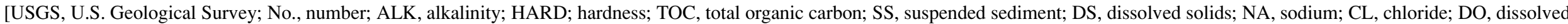

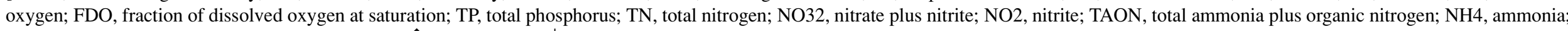
B, boron, PB, lead; BACT, fecal-coliform bacteria; $\uparrow$, positive trend; $\downarrow$, negative trend; $\leftrightarrow$, no trend (slope is not significant at the 0.05 level); -, insufficient data for analysis; --, no total]

\begin{tabular}{|c|c|c|c|c|c|c|c|c|c|c|c|c|c|c|c|c|c|c|c|c|c|c|}
\hline River basin & $\begin{array}{l}\text { USGS station } \\
\text { number }\end{array}$ & ALK & HARD & TOC & SS & DS & NA & $\mathrm{CL}$ & DO & FDO & $\mathrm{TP}$ & $\mathrm{TN}$ & NO32 & $\mathrm{NO} 2$ & TAON & $\mathrm{NH} 4$ & B & PB & BACT & $\begin{array}{l}\text { No. of con- } \\
\text { stituents } \\
\text { with a posi- } \\
\text { tive trend }\end{array}$ & $\begin{array}{l}\text { No. of con- } \\
\text { stituents } \\
\text { with a nega- } \\
\text { tive trend }\end{array}$ & $\begin{array}{l}\text { No. of con- } \\
\text { stituents } \\
\text { with no } \\
\text { trend }\end{array}$ \\
\hline \multirow[t]{2}{*}{ Assunpink } & 01463620 & - & - & - & - & - & - & - & - & - & - & - & - & - & - & - & - & - & - & 0 & 0 & 0 \\
\hline & 01464000 & - & - & - & - & - & - & - & $\leftrightarrow$ & $\leftrightarrow$ & - & - & $\leftrightarrow$ & $\downarrow$ & - & - & - & - & $\leftrightarrow$ & 0 & 1 & 4 \\
\hline Crosswicks & 01464500 & - & - & - & - & - & - & - & - & - & - & - & - & - & - & - & - & - & - & 0 & 0 & 0 \\
\hline Doctors & 01464515 & - & - & - & - & - & - & - & - & - & - & - & - & - & - & - & - & - & - & 0 & 0 & 0 \\
\hline South Branch Rancocas & 01465850 & - & - & - & - & - & - & - & - & - & - & - & - & - & - & - & - & - & - & 0 & 0 & 0 \\
\hline McDonalds & 01466500 & - & - & - & $\leftrightarrow$ & $\leftrightarrow$ & - & $\leftrightarrow$ & $\leftrightarrow$ & $\leftrightarrow$ & $\leftrightarrow$ & - & $\leftrightarrow$ & - & - & - & - & - & - & 0 & 0 & 7 \\
\hline North Branch Rancocas & 01467000 & - & - & - & - & - & - & - & - & - & - & - & - & - & - & - & - & - & - & 0 & 0 & 0 \\
\hline North Branch Pennsauken & 01467069 & - & - & - & - & - & - & - & - & - & - & - & - & - & - & - & - & - & - & 0 & 0 & 0 \\
\hline South Branch Pennsauken & 01467081 & - & - & - & - & - & - & - & - & - & - & - & - & - & - & - & - & - & - & 0 & 0 & 0 \\
\hline Cooper & 01467150 & - & - & - & - & - & - & - & $\leftrightarrow$ & $\leftrightarrow$ & - & $\downarrow$ & $\leftrightarrow$ & $\downarrow$ & $\downarrow$ & $\leftrightarrow$ & - & - & $\leftrightarrow$ & 0 & 3 & 5 \\
\hline South Branch Big Timber & 01467329 & - & - & - & - & - & - & - & - & - & - & - & - & - & - & - & - & - & - & 0 & 0 & 0 \\
\hline Raccoon & 01477120 & - & $\leftrightarrow$ & $\leftrightarrow$ & - & $\uparrow$ & $\uparrow$ & $\uparrow$ & $\leftrightarrow$ & $\leftrightarrow$ & - & $\leftrightarrow$ & $\leftrightarrow$ & - & $\leftrightarrow$ & - & - & - & $\leftrightarrow$ & 3 & 0 & 8 \\
\hline Salem & 01482500 & - & - & - & - & - & - & - & - & - & - & - & - & - & - & - & - & - & - & 0 & 0 & 0 \\
\hline Cohansey & 01412800 & - & $\leftrightarrow$ & $\leftrightarrow$ & - & $\leftrightarrow$ & $\leftrightarrow$ & $\leftrightarrow$ & $\leftrightarrow$ & $\leftrightarrow$ & - & $\leftrightarrow$ & $\leftrightarrow$ & - & $\leftrightarrow$ & $\downarrow$ & - & - & $\leftrightarrow$ & 0 & 1 & 11 \\
\hline \multirow[t]{2}{*}{ Maurice } & 01411500 & - & $\uparrow$ & - & - & $\downarrow$ & $\leftrightarrow$ & $\leftrightarrow$ & $\leftrightarrow$ & $\leftrightarrow$ & $\downarrow$ & $\leftrightarrow$ & $\leftrightarrow$ & - & $\leftrightarrow$ & - & - & - & - & 1 & 2 & 8 \\
\hline & 01411800 & - & - & - & - & - & - & - & - & - & - & - & - & - & - & - & - & - & - & 0 & 0 & 0 \\
\hline \multicolumn{2}{|c|}{ No. of stations with a positive trend } & 0 & 1 & 0 & 0 & 1 & 1 & 1 & 0 & 0 & 0 & 0 & 0 & 0 & 0 & 0 & 0 & 0 & 0 & -- & -- & -- \\
\hline \multicolumn{2}{|c|}{ No. of stations with a negative trend } & 0 & 0 & 0 & 0 & 1 & 0 & 0 & 0 & 0 & 1 & 1 & 0 & 2 & 1 & 1 & 0 & 0 & 0 & -- & -- & -- \\
\hline \multicolumn{2}{|l|}{ No. of stations with no trend } & 0 & 2 & 2 & 1 & 2 & 2 & 3 & 6 & 6 & 1 & 3 & 6 & 0 & 3 & 1 & 0 & 0 & 4 & -- & -- & -- \\
\hline
\end{tabular}


Table 37. Seasonal dependency at surface-water-quality stations in the Atlantic Coastal Basins, N.J., water years 1976-93

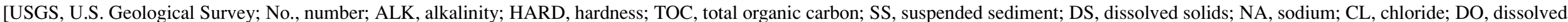

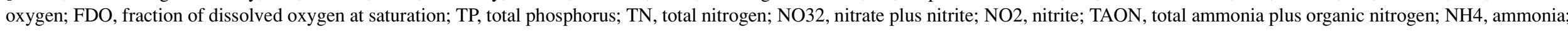

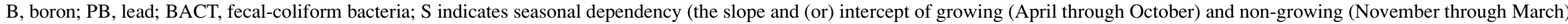

season data were different at the 0.05 significance level; -, no seasonal dependency or insufficient data for analysis; --, no total]

\begin{tabular}{|c|c|c|c|c|c|c|c|c|c|c|c|c|c|c|c|c|c|c|c|c|}
\hline River basin & $\begin{array}{l}\text { USGS } \\
\text { station } \\
\text { number }\end{array}$ & ALK & HARD & TOC & SS & DS & NA & $\mathrm{CL}$ & DO & FDO & $\mathrm{TP}$ & $\mathrm{TN}$ & NO32 & $\mathrm{NO} 2$ & TAON & NH4 & $\mathrm{B}$ & PB & BACT & $\begin{array}{c}\text { No. of constituents } \\
\text { with seasonal } \\
\text { dependency }\end{array}$ \\
\hline Manasquan & 01408000 & - & - & - & - & - & - & - & $\mathrm{S}$ & $\mathrm{S}$ & $\mathrm{S}$ & $\mathrm{S}$ & - & $\mathrm{S}$ & - & $\mathrm{S}$ & - & - & $S$ & 7 \\
\hline Toms & 01408500 & - & $S$ & $S$ & $S$ & - & $\mathrm{S}$ & - & $\mathrm{S}$ & $\mathrm{S}$ & $\mathrm{S}$ & $S$ & $S$ & - & $S$ & - & - & $\mathrm{S}$ & - & 11 \\
\hline Mullica & 01409387 & - & $S$ & $S$ & - & - & $\mathrm{S}$ & - & $\mathrm{S}$ & - & - & - & $\mathrm{S}$ & $\mathrm{S}$ & - & $S$ & - & - & - & 7 \\
\hline Hammonton & 01409416 & - & $S$ & $S$ & $S$ & $S$ & $\mathrm{~S}$ & - & $\mathrm{S}$ & $\mathrm{S}$ & - & $\mathrm{S}$ & $S$ & - & - & $S$ & - & - & $S$ & 11 \\
\hline Batsto & 01409500 & $\mathrm{~S}$ & $S$ & $S$ & - & - & - & $\mathrm{S}$ & $\mathrm{S}$ & - & - & - & $S$ & - & - & - & - & - & - & 6 \\
\hline West Branch Wading & 01409815 & - & $S$ & - & $\mathrm{S}$ & $\mathrm{S}$ & $\mathrm{S}$ & - & $\mathrm{S}$ & $\mathrm{S}$ & $\mathrm{S}$ & $\mathrm{S}$ & - & - & $S$ & - & - & - & - & 9 \\
\hline Oswego & 01410000 & - & - & $S$ & - & - & - & - & $\mathrm{S}$ & - & - & $\mathrm{S}$ & - & - & $\mathrm{S}$ & - & - & - & - & 4 \\
\hline East Branch Bass & 01410150 & - & - & $S$ & - & - & - & - & $\mathrm{S}$ & $\mathrm{S}$ & - & - & - & - & - & - & - & - & - & 3 \\
\hline \multirow[t]{3}{*}{ Great Egg Harbor } & 01410784 & - & $S$ & $S$ & $\mathrm{~S}$ & $\mathrm{~S}$ & $\mathrm{~S}$ & $\mathrm{~S}$ & $\mathrm{~S}$ & $\mathrm{~S}$ & - & - & - & - & - & - & - & - & $S$ & 9 \\
\hline & 01411000 & - & - & - & - & - & - & - & $\mathrm{S}$ & $\mathrm{S}$ & $\mathrm{S}$ & - & $\mathrm{S}$ & - & - & - & - & - & $S$ & 5 \\
\hline & 01411110 & $S$ & - & $S$ & - & - & $\mathrm{S}$ & - & $\mathrm{S}$ & $\mathrm{S}$ & $\mathrm{S}$ & - & $S$ & - & $S$ & - & - & - & $S$ & 9 \\
\hline No. of stations with sea & ependency & 2 & 6 & 8 & 4 & 3 & 6 & 2 & 11 & 8 & 5 & 5 & 6 & 2 & 4 & 3 & 0 & 1 & 5 & -- \\
\hline
\end{tabular}


Table 38. Seasonal dependency at surface-water-quality stations in the lower Delaware River and Delaware Bay Basins, N.J., water years 1976-93

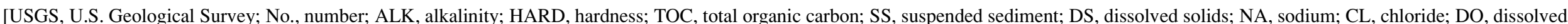

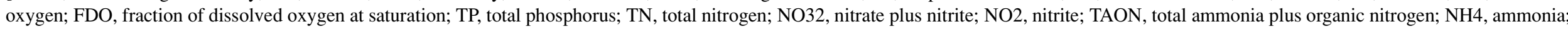

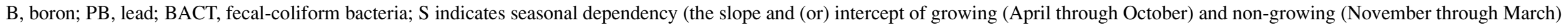

season data were different at the 0.05 significance level; -, no seasonal dependency or insufficient data for analysis; --, no total]

\begin{tabular}{|c|c|c|c|c|c|c|c|c|c|c|c|c|c|c|c|c|c|c|c|c|}
\hline River basin & $\begin{array}{l}\text { USGS } \\
\text { station } \\
\text { number }\end{array}$ & ALK & HARD & TOC & SS & DS & NA & CL & DO & FDO & $\mathrm{TP}$ & $\mathrm{TN}$ & NO32 & $\mathrm{NO} 2$ & TAON & $\mathrm{NH} 4$ & B & PB & BACT & $\begin{array}{c}\text { No. of constituents } \\
\text { with seasonal } \\
\text { dependency }\end{array}$ \\
\hline \multirow[t]{2}{*}{ Assunpink } & 01463620 & $\mathrm{~S}$ & - & $S$ & - & - & $S$ & $S$ & $\mathrm{~S}$ & - & - & $S$ & $S$ & - & $S$ & - & - & - & - & 8 \\
\hline & 01464000 & - & - & - & - & - & - & $S$ & $S$ & $S$ & - & - & - & S & - & - & - & - & $S$ & 5 \\
\hline Crosswicks & 01464500 & $\mathrm{~S}$ & $S$ & $S$ & - & - & - & - & $\mathrm{S}$ & $S$ & - & - & $S$ & $S$ & $S$ & $S$ & - & - & $\mathrm{S}$ & 10 \\
\hline Doctors & 01464515 & $\mathrm{~S}$ & S & $S$ & - & - & $S$ & S & S & S & - & S & S & - & - & S & - & - & $\mathrm{S}$ & 11 \\
\hline South Branch Rancocas & 01465850 & - & $S$ & $S$ & - & - & $S$ & $S$ & $S$ & $S$ & $\mathrm{~S}$ & - & $S$ & - & $S$ & $S$ & - & - & $S$ & 11 \\
\hline McDonalds & 01466500 & - & $S$ & - & $\mathrm{S}$ & - & $S$ & - & $\mathrm{S}$ & $\mathrm{S}$ & - & - & $\mathrm{S}$ & - & - & - & - & - & - & 6 \\
\hline North Branch Rancocas & 01467000 & - & $S$ & $S$ & - & - & $S$ & $S$ & $S$ & $\mathrm{~S}$ & $S$ & $S$ & - & $S$ & $S$ & $S$ & - & - & $S$ & 12 \\
\hline North Branch Pennsauken & 01467069 & - & $S$ & $S$ & - & $S$ & $S$ & $S$ & $\mathrm{~S}$ & - & $\mathrm{S}$ & - & $\mathrm{S}$ & $S$ & - & $S$ & - & - & $S$ & 11 \\
\hline South Branch Pennsauken & 01467081 & - & $S$ & - & - & $S$ & $S$ & $S$ & $\mathrm{~S}$ & $S$ & - & - & - & $S$ & - & - & - & - & $S$ & 8 \\
\hline Cooper & 01467150 & - & $S$ & - & - & - & - & - & $S$ & $S$ & $\mathrm{~S}$ & - & - & $S$ & - & - & - & - & $S$ & 6 \\
\hline South Branch Big Timber & 01467329 & - & $\mathrm{S}$ & $\mathrm{S}$ & - & $S$ & $\mathrm{~S}$ & $S$ & $S$ & $\mathrm{~S}$ & $\mathrm{~S}$ & $S$ & $S$ & $S$ & - & $S$ & - & - & $\mathrm{S}$ & 13 \\
\hline Raccoon & 01477120 & $S$ & $S$ & $S$ & - & $S$ & - & - & $\mathrm{S}$ & - & $\mathrm{S}$ & - & $S$ & $S$ & $S$ & - & - & - & $S$ & 10 \\
\hline Oldmans & 01477510 & $\mathrm{~S}$ & - & $S$ & - & - & $S$ & - & $\mathrm{S}$ & - & $\mathrm{S}$ & $S$ & $\mathrm{~S}$ & $S$ & S & - & - & - & $\mathrm{S}$ & 10 \\
\hline Salem & 01482500 & $S$ & $S$ & $S$ & $\mathrm{~S}$ & - & $S$ & $S$ & $S$ & - & $S$ & $S$ & $S$ & $S$ & $S$ & - & - & - & - & 12 \\
\hline Cohansey & 01412800 & $\mathrm{~S}$ & - & $S$ & - & - & - & - & $\mathrm{S}$ & - & - & $S$ & $\mathrm{~S}$ & $S$ & - & - & - & - & $\mathrm{S}$ & 7 \\
\hline \multirow[t]{2}{*}{ Maurice } & 01411500 & $S$ & $S$ & $S$ & $\mathrm{~S}$ & - & - & $S$ & $S$ & $S$ & $S$ & $S$ & $S$ & - & $S$ & - & - & - & $S$ & 12 \\
\hline & 01411800 & - & - & - & - & - & - & - & $S$ & $\mathrm{~S}$ & - & $\mathrm{S}$ & $\mathrm{S}$ & $\mathrm{S}$ & $S$ & - & - & - & $\mathrm{S}$ & 7 \\
\hline \multicolumn{2}{|c|}{ No. of stations with seasonal dependency } & 8 & 12 & 12 & 3 & 4 & 10 & 10 & 17 & 11 & 9 & 9 & 13 & 12 & 9 & 6 & 0 & 0 & 14 & -- \\
\hline
\end{tabular}


Table 39. Maximum, minimum, and spread of load-to-streamflow slopes for selected constituents at surface-water-quality stations in the Atlantic Coastal Basins, N.J., water years 1976-93

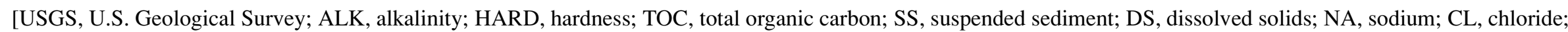
H, high-slope category; L, low-slope category; -, moderate-slope category; ND, not determined; --, no total]

\begin{tabular}{|c|c|c|c|c|c|c|c|c|c|c|}
\hline River basin & $\begin{array}{c}\text { USGS station } \\
\text { number }\end{array}$ & ALK & HARD & TOC & SS & DS & NA & $\mathrm{CL}$ & $\begin{array}{l}\text { Number of } \\
\text { constituents with } \\
\text { high slopes }\end{array}$ & $\begin{array}{c}\text { Number of } \\
\text { constituents with } \\
\text { low slopes }\end{array}$ \\
\hline Manasquan & 01408000 & - & $\mathrm{L}$ & - & $\mathrm{H}$ & - & - & - & 1 & 1 \\
\hline Toms & 01408500 & - & $\mathrm{L}$ & - & - & - & - & - & 0 & 1 \\
\hline Mullica & 01409387 & $\mathrm{~L}$ & - & - & $\mathrm{L}$ & - & $\mathrm{H}$ & $\mathrm{H}$ & 2 & 2 \\
\hline Hammonton & 01409416 & $\mathrm{H}$ & - & $\mathrm{L}$ & $\mathrm{L}$ & $\mathrm{L}$ & $\mathrm{L}$ & - & 1 & 4 \\
\hline Batsto & 01409500 & $\mathrm{~L}$ & $\mathrm{H}$ & - & - & $\mathrm{H}$ & $\mathrm{H}$ & $\mathrm{H}$ & 4 & 1 \\
\hline West Branch Wading & 01409815 & $\mathrm{H}$ & - & $\mathrm{L}$ & $\mathrm{L}$ & - & - & - & 1 & 2 \\
\hline Oswego & 01410000 & $\mathrm{ND}$ & - & - & - & - & - & - & 0 & 0 \\
\hline East Branch Bass & 01410150 & $\mathrm{~L}$ & - & $\mathrm{H}$ & - & - & $\mathrm{H}$ & $\mathrm{H}$ & 3 & 1 \\
\hline \multirow[t]{3}{*}{ Great Egg Harbor } & 01410784 & - & $\mathrm{L}$ & - & - & - & - & - & 0 & 1 \\
\hline & 01411000 & $\mathrm{~L}$ & - & $\mathrm{H}$ & $\mathrm{L}$ & - & - & - & 1 & 2 \\
\hline & 01411110 & $\mathrm{~L}$ & - & $\mathrm{H}$ & - & - & - & - & 1 & 1 \\
\hline \multicolumn{2}{|c|}{ Number of stations with high slopes } & 2 & 1 & 3 & 1 & 1 & 3 & 3 & -- & -- \\
\hline \multicolumn{2}{|c|}{ Number of stations with low slopes } & 5 & 3 & 2 & 4 & 1 & 1 & 0 & -- & -- \\
\hline \multicolumn{2}{|l|}{ Maximum slope } & .98 & 1.31 & 1.79 & 2.32 & 1.35 & 1.08 & 1.13 & -- & -- \\
\hline \multicolumn{2}{|l|}{ Minimum slope } & 0 & .70 & .84 & .95 & .74 & .61 & .64 & -- & -- \\
\hline \multicolumn{2}{|c|}{ Spread between maximum and minimum slopes } & .98 & .61 & .95 & 1.37 & .61 & .47 & .49 & -- & -- \\
\hline
\end{tabular}


Table 40. Maximum, minimum, and spread of load-to-streamflow slopes for selected constituents at surface-water-quality stations in the lower Delaware River and Delaware Bay Basins, N.J., water years 1976-93

[USGS, U.S. Geological Survey; ALK, alkalinity; HARD, hardness; TOC, total organic carbon; SS, suspended sediment; DS, dissolved solids; NA, sodium; CL, chloride; H, high-slope category; L, low-slope category; -, moderate-slope category; ND, not determined; --, no total]

\begin{tabular}{|c|c|c|c|c|c|c|c|c|c|c|}
\hline River basin & $\begin{array}{c}\text { USGS station } \\
\text { number }\end{array}$ & ALK & HARD & TOC & SS & DS & NA & $\mathrm{CL}$ & $\begin{array}{c}\text { Number of } \\
\text { constituents with } \\
\text { high slopes }\end{array}$ & $\begin{array}{c}\text { Number of } \\
\text { constituents with } \\
\text { low slopes }\end{array}$ \\
\hline \multirow[t]{2}{*}{ Assunpink } & 01463620 & - & - & $\mathrm{L}$ & - & - & $\mathrm{H}$ & - & 1 & 1 \\
\hline & 01464000 & - & $\mathrm{L}$ & - & - & $\mathrm{L}$ & $\mathrm{L}$ & $\mathrm{L}$ & 0 & 4 \\
\hline Crosswicks & 01464500 & - & $\mathrm{L}$ & - & $\mathrm{H}$ & $\mathrm{L}$ & $\mathrm{L}$ & - & 1 & 3 \\
\hline Doctors & 01464515 & $\mathrm{H}$ & - & $\mathrm{L}$ & - & - & - & - & 1 & 1 \\
\hline South Branch Rancocas & 01465850 & - & - & - & $\mathrm{L}$ & - & - & - & 0 & 1 \\
\hline McDonalds & 01466500 & ND & - & $\mathrm{H}$ & $\mathrm{L}$ & $\mathrm{H}$ & - & - & 2 & 1 \\
\hline North Branch Rancocas & 01467000 & - & - & - & - & - & - & - & 0 & 0 \\
\hline North Branch Pennsauken & 01467069 & $\mathrm{H}$ & - & $\mathrm{L}$ & $\mathrm{L}$ & - & - & - & 1 & 2 \\
\hline South Branch Pennsauken & 01467081 & - & $\mathrm{L}$ & - & - & $\mathrm{L}$ & $\mathrm{L}$ & - & 0 & 3 \\
\hline Cooper & 01467150 & $\mathrm{H}$ & - & - & - & - & $\mathrm{H}$ & - & 2 & 0 \\
\hline South Branch Big Timber & 01467329 & $\mathrm{H}$ & - & - & - & - & - & - & 1 & 0 \\
\hline Raccoon & 01477120 & - & $\mathrm{L}$ & - & - & $\mathrm{L}$ & - & - & 0 & 2 \\
\hline Oldmans & 01477510 & - & $\mathrm{L}$ & $\mathrm{L}$ & - & - & $\mathrm{H}$ & - & 1 & 2 \\
\hline Salem & 01482500 & $\mathrm{H}$ & - & $\mathrm{L}$ & $\mathrm{L}$ & - & - & - & 1 & 2 \\
\hline Cohansey & 01412800 & $\mathrm{H}$ & - & - & - & $\mathrm{L}$ & $\mathrm{L}$ & $\mathrm{L}$ & 1 & 3 \\
\hline \multirow[t]{2}{*}{ Maurice } & 01411500 & - & - & $\mathrm{H}$ & - & - & - & - & 1 & 0 \\
\hline & 01411800 & ND & - & - & ND & - & - & - & 0 & 0 \\
\hline \multicolumn{2}{|c|}{ Number of stations with high slopes } & 6 & 0 & 2 & 1 & 1 & 3 & 0 & -- & -- \\
\hline \multicolumn{2}{|c|}{ Number of stations with low slopes } & 0 & 5 & 5 & 4 & 5 & 4 & 2 & -- & -- \\
\hline \multicolumn{2}{|l|}{ Maximum slope } & .98 & 1.31 & 1.79 & 2.32 & 1.35 & 1.08 & 1.13 & -- & -- \\
\hline \multicolumn{2}{|l|}{ Minimum slope } & 0 & .70 & .84 & .95 & .74 & .61 & .64 & -- & -- \\
\hline \multicolumn{2}{|c|}{ Spread between maximum and minimum slopes } & .98 & 61 & .95 & 1.37 & .61 & .47 & .49 & -- & -- \\
\hline
\end{tabular}




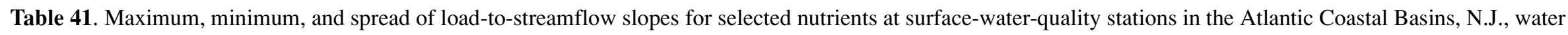
years 1976-93

[USGS, U.S. Geological Survey; TP, total phosphorus; TN, total nitrogen; NO32, nitrate plus nitrite; NO2, nitrite; TAON, total ammonia plus organic nitrogen; NH4, ammonia; H, high-slope category; L, low-slope category; -, moderate-slope category; ND, not determined; --no total]

\begin{tabular}{|c|c|c|c|c|c|c|c|c|c|}
\hline River basin & $\begin{array}{l}\text { USGS station } \\
\text { number }\end{array}$ & $\mathrm{TP}$ & $\mathrm{TN}$ & NO32 & NO2 & TAON & NH4 & $\begin{array}{c}\text { Number of } \\
\text { constituents with } \\
\text { high slopes }\end{array}$ & $\begin{array}{c}\text { Number of } \\
\text { constituents with } \\
\text { low slopes }\end{array}$ \\
\hline Manasquan & 01408000 & $\mathrm{H}$ & $\mathrm{H}$ & - & - & - & $\mathrm{H}$ & 3 & 0 \\
\hline Toms & 01408500 & $\mathrm{~L}$ & $\mathrm{~L}$ & $\mathrm{~L}$ & - & - & $\mathrm{L}$ & 0 & 4 \\
\hline Mullica & 01409387 & - & - & - & - & $\mathrm{L}$ & - & 0 & 1 \\
\hline Hammonton & 01409416 & $\mathrm{~L}$ & $\mathrm{~L}$ & - & - & $\mathrm{L}$ & - & 0 & 3 \\
\hline Batsto & 01409500 & - & $\mathrm{H}$ & - & - & - & $\mathrm{H}$ & 2 & 0 \\
\hline West Branch Wading & 01409815 & - & - & - & ND & - & $\mathrm{L}$ & 0 & 1 \\
\hline Oswego & 01410000 & - & - & - & $\mathrm{H}$ & - & - & 1 & 0 \\
\hline East Branch Bass & 01410150 & - & - & - & $\mathrm{H}$ & - & $\mathrm{L}$ & 1 & 1 \\
\hline \multirow[t]{3}{*}{ Great Egg Harbor } & 01410784 & $\mathrm{~L}$ & $\mathrm{~L}$ & $\mathrm{~L}$ & - & - & - & 0 & 3 \\
\hline & 01411000 & - & - & $\mathrm{L}$ & - & - & $\mathrm{L}$ & 0 & 2 \\
\hline & 01411110 & - & - & $\mathrm{L}$ & $\mathrm{H}$ & - & - & 1 & 1 \\
\hline \multicolumn{2}{|c|}{ Number of stations with high slopes } & 1 & 2 & 0 & 3 & 0 & 2 & -- & -- \\
\hline \multicolumn{2}{|c|}{ Number of stations with low slopes } & 3 & 3 & 4 & 0 & 2 & 4 & -- & -- \\
\hline \multicolumn{2}{|l|}{ Maximum slope } & 1.55 & 1.39 & 2.17 & 1.44 & 1.75 & 1.73 & -- & -- \\
\hline \multicolumn{2}{|l|}{ Minimum slope } & .50 & .64 & .28 & .23 & .69 & .42 & -- & -- \\
\hline \multicolumn{2}{|c|}{ Spread of maximum and minimum slopes } & 1.05 & .75 & 1.89 & 1.21 & 1.06 & 1.31 & -- & -- \\
\hline
\end{tabular}




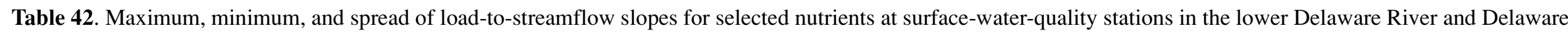
Bay Basins, N.J., water years 1976-93

[USGS, U.S. Geological Survey; TP, total phosphorus; TN, total nitrogen; NO32, nitrate plus nitrite; NO2, nitrite; TAON, total ammonia plus organic nitrogen; NH4, ammonia; H, high-slope category; L, low-slope category; -, moderate-slope category; ND, not determined; --no total]

\begin{tabular}{|c|c|c|c|c|c|c|c|c|c|}
\hline River basin & $\begin{array}{c}\text { USGS station } \\
\text { number }\end{array}$ & $\mathrm{TP}$ & $\mathrm{TN}$ & NO32 & $\mathrm{NO} 2$ & TAON & NH4 & $\begin{array}{c}\text { Number of } \\
\text { constituents with } \\
\text { high slopes }\end{array}$ & $\begin{array}{c}\text { Number of } \\
\text { constituents with } \\
\text { low slopes }\end{array}$ \\
\hline \multirow[t]{2}{*}{ Assunpink } & 01463620 & - & - & - & $\mathrm{H}$ & - & - & 1 & 0 \\
\hline & 01464000 & $\mathrm{~L}$ & $\mathrm{~L}$ & $\mathrm{~L}$ & - & $\mathrm{L}$ & - & 0 & 4 \\
\hline Crosswicks & 01464500 & - & $\mathrm{L}$ & $\mathrm{L}$ & - & - & - & 0 & 1 \\
\hline Doctors & 01464515 & - & - & - & - & $\mathrm{L}$ & $\mathrm{L}$ & 0 & 3 \\
\hline South Branch Rancocas & 01465850 & $\mathrm{~L}$ & - & - & - & $\mathrm{L}$ & $\mathrm{L}$ & 0 & 3 \\
\hline McDonalds & 01466500 & - & $\mathrm{H}$ & - & ND & $\mathrm{H}$ & - & 2 & 0 \\
\hline North Branch Rancocas & 01467000 & - & - & - & $\mathrm{H}$ & $\mathrm{L}$ & $\mathrm{L}$ & 1 & 2 \\
\hline North Branch Pennsauken & 01467069 & - & - & - & - & $\mathrm{L}$ & - & 0 & 1 \\
\hline South Branch Pennsauken & 01467081 & - & $\mathrm{L}$ & - & $\mathrm{L}$ & $\mathrm{L}$ & $\mathrm{L}$ & 0 & 4 \\
\hline Cooper & 01467150 & - & - & - & $\mathrm{H}$ & - & - & 1 & 0 \\
\hline South Branch Big Timber & 01467329 & - & - & - & - & - & - & 0 & 0 \\
\hline Raccoon & 01477120 & - & $\mathrm{H}$ & - & - & - & - & 1 & 0 \\
\hline Oldmans & 01477510 & - & - & - & - & $\mathrm{L}$ & - & 0 & 1 \\
\hline Salem & 01482500 & - & $\mathrm{H}$ & $\mathrm{H}$ & $\mathrm{H}$ & - & - & 3 & 0 \\
\hline Cohansey & 01412800 & $\mathrm{H}$ & - & - & $\mathrm{H}$ & - & - & 2 & 0 \\
\hline \multirow[t]{2}{*}{ Maurice } & 01411500 & - & $\mathrm{L}$ & $\mathrm{L}$ & - & - & - & 0 & 2 \\
\hline & 01411800 & - & - & - & - & $\mathrm{L}$ & $\mathrm{L}$ & 0 & 2 \\
\hline \multicolumn{2}{|c|}{ Number of stations with high slopes } & 1 & 3 & 1 & 5 & 1 & 0 & -- & -- \\
\hline \multicolumn{2}{|c|}{ Number of stations with low slopes } & 2 & 4 & 3 & 1 & 8 & 5 & -- & -- \\
\hline \multicolumn{2}{|l|}{ Maximum slope } & 1.55 & 1.39 & 2.17 & 1.44 & 1.75 & 1.73 & -- & -- \\
\hline \multicolumn{2}{|l|}{ Minimum slope } & .50 & .64 & .28 & .23 & .69 & .42 & -- & -- \\
\hline \multicolumn{2}{|c|}{ Spread of maximum and minimum slopes } & 1.05 & .75 & 1.89 & 1.21 & 1.06 & 1.31 & -- & -- \\
\hline
\end{tabular}




\section{SUMMARY}

The U.S. Geological Survey, in cooperation with the New Jersey Department of Environmental Protection, investigated the quality of surface water in the Atlantic Coastal, lower Delaware River, and Delaware Bay Basins during water years 1976-93. After selection of the appropriate surface-water-quality stations, constituents, and period of record, the water-quality data, instantaneous streamflow data, and flow durations were compiled and checked for accuracy. A project data base was maintained, and statistical parameters, such as median constituent concentrations, slopes of regression for load to streamflow and concentration to streamflow, and trends in constituent concentrations over time, were determined. Eighteen water-quality constituents at 28 surface-water-quality stations were investigated. The relative contributions of constant and intermittent sources of water-quality constituents were evaluated by testing for trends in concentrations during low and high flows, and qualitative values of source contributions were estimated by statistically defining the relations between concentration and streamflow, and load and streamflow.

Results of trend analysis can indicate the relative contributions of constant and intermittent sources to stream-water quality over time within a basin. A trend in concentrations during high-flow conditions can indicate increasing or decreasing intermittent source contributions over time, and a trend in concentrations during low-flow conditions can indicate increasing or decreasing constant-source contributions over time. A conservative method was used to determine trends during low and high flows. The use of flow duration values covering a greater range would possibly allow additional significant trends to be determined.

The slopes of load to streamflow were grouped into low (less than or equal to 25 percent of the interval between the minimum and maximum slopes of each constituent), medium (greater than 25 percent to less than 75 percent of the slope interval), and high (greater than 75 percent of the slope interval) ranges in order to compare sites by constituent. At sites with slopes in the high range, contributions to instream loads from storm runoff probably are larger than at other sites in the study area, indicating an increased relative importance of intermittent (nonpoint storm runoff) source contributions. At sites with slopes in the low range, contributions to instream loads from intermittent sources probably are smaller than at other sites in the study area, indicating an increased relative importance of constant (point sources and ground water) source contributions. For constituents with large slopes of load to streamflow, greater than 0.8 , (for example, total organic carbon and suspended sediment), storm runoff is most likely the significant contributor to instream loads, even for stations with slopes in the low range. Constituent concentrations cannot be related to streamflow in the same way as load because contributions from storm runoff are flow dependent. Overall, slopes of load-to-streamflow relations tend to be higher for stations in this study area than in the Hackensack, Passaic, Elizabeth, and Rahway River Basins, indicating a greater relative influence of contributions from intermittent sources.

Trends in concentrations during low flows are positive (increasing constant-rate source contributions) at one station for total nitrate plus nitrite; at two stations for hardness, dissolved oxygen, and fraction of dissolved oxygen at saturation; at three stations for fecal coliform bacteria; at six stations for dissolved sodium; and at nine stations for dissolved chloride. Trends during low flows are negative (decreasing constant-rate source contributions) at one station for total organic carbon, total phosphorus, total nitrite, and total lead; at two stations for dissolved 
chloride, total nitrogen, and total nitrate plus nitrite; at three stations for dissolved sodium, fraction of dissolved oxygen at saturation, and total ammonia; and at six stations for total ammonia plus organic nitrogen.

Trends in concentrations during high flows are positive (increasing intermittent-source contributions) at one station for hardness, dissolved solids, and dissolved sodium and at two stations for dissolved chloride. Trends during high flows are negative (decreasing intermittentsource contributions) at one station for dissolved solids, total nitrogen, and total ammonia plus organic nitrogen, and at two stations for total phosphorus and total nitrite.

Two of the 28 water-quality stations have insufficient data to determine trends during both high and low flows. Sufficient data are available to determine trends during low flows at all water-quality stations in the Atlantic Coastal Basin and 12 stations in the lower Delaware River and Delaware Bay Basins. Sufficient data are available to determine trends during high flows at only one station in the Atlantic Coastal Basin and five stations in the lower Delaware River and Delaware Bay Basins. Trends tests were conducted only if there was at least one measurement in each period of not less than four of the six water years in each one-third of the period of study (18 years); a lack of data results in no trend.

Concentration-to-streamflow relations show seasonal dependency at one or more stations for 17 of the 18 constituents. Seasonal dependency is not evident at any station for total boron and at only one for total lead. Seasonal dependency is evident at 14 or more stations for hardness, total organic carbon, dissolved sodium, dissolved oxygen, fraction of dissolved oxygen at saturation, total phosphorus, total nitrogen, total nitrate plus nitrite, total nitrite, and fecal coliform bacteria. Dissolved oxygen shows seasonal dependency at all stations, possibly because of its relation to bioactivity in surface water. Dissolved sodium and hardness show seasonal dependency most likely as a result of road salting; however, dissolved solids shows seasonal dependency only at six stations.

The change in the load-to-streamflow relations along a river reach in the downstream direction indicates the changing relative importance of intermittent sources along the river. The magnitudes of the load slopes for hardness, total phosphorus, total nitrogen, total nitrite, and total ammonia plus organic nitrogen increase along the Great Egg Harbor River, indicating an increase in the relative influence of contributions from storm runoff along the river. The magnitudes of the load slopes for alkalinity, hardness, dissolved solids, dissolved sodium, dissolved chloride, total phosphorus, total nitrogen, total nitrate plus nitrite, total nitrite, total ammonia plus organic nitrogen, and total ammonia decrease along the Assunpink Creek as do the load slopes for total organic carbon, dissolved sodium, dissolved chloride, total ammonia plus organic nitrogen, and total ammonia along the Maurice River, indicating a decrease in the relative influence of contributions from storm runoff along the rivers.

The relation of load to streamflow provides a qualitative estimate of the relative contributions of nonpoint storm runoff and ground water, and point sources, to surface-water quality and represents preliminary results for the total maximum daily load process for the State's watersheds. The results of this study, along with identification of constant-rate sources, additional water-quality data collected during low and high flows, and ground-water data (water-quality data, water levels, flow rates, and travel times) could facilitate a more detailed analysis of the overall hydrology of these river basins. 


\section{REFERENCES CITED}

Anderson, P.W., and George, J.R., 1966, Water-quality characteristics of New Jersey streams: U.S. Geological Survey Water-Supply Paper 1819-G, 48 p.

Anderson, P.W., and McCarthy, L.T., Jr., 1963, Chemical character of streams in the Delaware River basin: U.S. Geological Survey Open-File Report, 11 p.

Barnes, R.S.K., and Mann, K.H., eds., 1991, Fundamentals of aquatic ecology: Oxford, Blackwell Scientific Publications, 270 p.

Bauersfeld, W.R., Moshinsky, E.W., and Gurney, C.E., 1994, Water resources data for New Jersey - water year 1993, volume 1, surface-water data: U.S. Geological Survey WaterData Report NJ-93-1, 503 p.

Bauersfeld, W.R., Moshinsky, E.W., Pustay, E.A., and Jones, W.D., 1990, Water resources data for New Jersey—water year 1989, volume 2, Delaware River Basin and Tributaries to Delaware Bay: U.S. Geological Survey Water-Data Report NJ-89-2, 215 p.

Breidt, F.J., Boes, D.C., Wagner, J.I., and Flora, M.D., 1991, Antidegradation water quality criteria for the Delaware River: A distribution-free statistical approach: Water Resources Bulletin, v. 27, no.5, p. 849-858.

Buxton, D.E., and Dunne, Paul, 1993, Water-quality data for the Millstone River at Weston, New Jersey, and the Shark River at Remsen Mill, New Jersey, March-September 1992: U.S. Geological Survey Open-File Report 93-444, 16 p.

Buxton, D.E., Hunchak-Kariouk, Kathryn, and Hickman, R.E., 1998, Relations of surface-water quality to streamflow in the Hackensack, Passaic, Elizabeth, and Rahway River Basins: U.S. Geological Survey Water-Resources Investigations Report 98-4049, 102 p.

Chow, V.T., 1964, Handbook of applied hydrology: New York, McGraw Hill, Inc., 1418 p.

Cohn, T.A., 1988, Adjusted maximum estimation of the moments of lognormal populations from type 1 censored samples: U.S. Geological Survey Open-File Report 88-350, 34 p.

Eaton, A.D., Clesceri, L.S., and Greenberg, A.E., eds., 1995, Standard methods for the examination of water and wastewater (19th ed.): Washington, D.C., American Public Health Association, 948 p.

Fishman, M.J., Raese, J.W., Gerlitz, C.N., and Husband, R.A., 1994, U.S. Geological Survey approved inorganic and organic methods for the analysis of water and fluvial sediments, 1954-94: U.S. Geological Survey Open-File Report 94-351, 55 p.

Friedman, L.C., and Fishman, M.J., 1989, Evaluation of methods used from 1965 through 1982 to determine inorganic constituents in water samples: U.S. Geological Survey Water-Supply Paper 2293, $126 \mathrm{p}$. 


\section{REFERENCES CITED-Continued}

Fusillo, T.V., 1981, Impact of Suburban Residential Development on Water Resources in the Area of Winslow Township, Camden County, New Jersey: U.S. Geological Survey WaterResources Investigations Report 81-27, 38 p.

Gillespie, B.D., and Schopp, R.D., 1982, Low-flow characteristics and flow duration of New Jersey streams: U.S. Geological Survey Open-File Report 81-1110, 164 p.

Hay, L.E., and Campbell, J.P., 1990, Water-quality trends in New Jersey streams: U.S. Geological Survey Water-Resources Investigations Report 90-4046, 297 p.

Helsel, D.R., and Cohn, T.A., 1988, Estimation of descriptive statistics for multiply censored water quality data: Water Resources Research, v. 24, no. 12, p. 1997-2004.

Helsel, D.R., and Hirsch, R.M., 1992, Statistical methods in water resources: New York, Elsevier Science Publishing Company, $522 \mathrm{p}$.

Hely, A.G., and Olmsted, F.H., 1963, Some relations between streamflow characteristics and the environment in the Delaware River region: U.S. Geological Survey Professional Paper 417-B. p. B1-B5.

Hem, J.D., 1985, Study and interpretation of the chemical characteristics of natural water: U.S. Geological Survey Water Supply Paper 2254, 263 p.

Hickman, R.E., 1992, Water-quality data from reconnaissance surveys of selected estuaries in southern New Jersey, July-October 1989: U.S. Geological Survey Open-File Report 91-491, 61 p.

Hickman, R.E., 1995, Statistical characteristics of stream discharge in tributaries of selected estuaries in New Jersey: U.S. Geological Survey Water-Resources Investigations Report 91-4141, 53 p.

Hirsch, R.M., 1982, A comparison of four streamflow record extension techniques: Water Resources Research, v. 18, no. 4, p. 1081-1088.

Hirsch, R.M., Slack, J.R., and Smith, R.A., 1982, Techniques of trend analysis for monthly water quality data: Water Resources Research, v. 18, p. 107-121.

Hochreiter, Jr., J.J., 1982, Chemical-quality reconnaissance of the water and surficial bed material in the Delaware River estuary and adjacent New Jersey tributaries, 1980-81: U.S. Geological Survey Water-Resources Investigations Report 82-36, 41 p. 


\section{REFERENCES CITED-Continued}

Hochreiter Jr., J.J., and Kozinski, Jane, 1985, Quality of water and bed material in streams of Logan Township, Gloucester County, New Jersey: U.S. Geological Survey WaterResources Investigations Report 85-4300, 39p.

Hutchison, N.E., 1975, WATSTORE: National Water Data Storage and Retrieval System: user's guide: U.S. Geological Survey Open-File Report 75-426, 791 p.

Ivahnenko, Tamara, and Buxton, D.E., 1994, Agricultural pesticides in six drainage basins used for public water supply in New Jersey, 1990: U.S. Geological Survey Water-Resources Investigations Report 93-4101, 56 p.

Keighton, W.B., 1965, Delaware River water quality, Bristol to Marcus Hook, Pennsylvania, August 1949 to December 1963: U.S. Geological Survey Water-Supply Paper 1809-O, $57 \mathrm{p}$.

Keighton, W.B., 1966, Fresh-water discharge-salinity relations in the tidal Delaware River: U.S. Geological Survey Water-Supply Paper 1586-G, 16 p.

Keighton, W.B., 1969, Water quality in the Delaware estuary for two years of drought; 1965 and 1966 from Trenton, New Jersey to Reedy Island, Delaware: U.S. Geological Survey Hydrologic Investigations Atlas 335, 2 sheets, scale 1:1,000,000.

Mansue, L.J., 1972, Suspended-sediment yields of New Jersey Coastal Plain streams draining into the Delaware estuary: U.S. Geological Survey Open-File Report, 26 p.

New Jersey Department of Environmental Protection and Energy, 1993, New Jersey 1992 State Water Quality Inventory Report: New Jersey Department of Environmental Protection and Energy, Office of Land and Water Planning, Trenton, New Jersey, 472 p.

New Jersey Department of Environmental Protection, 1989, Nonpoint Source Assessment and Management Program, Division of Water Resources, Trenton, New Jersey, 97 p.

1996a, Ambient Monitoring Network: Atlantic Coastal Drainage Basin, 1994-95 benthic macroinvertebrate data: Trenton, New Jersey, Executive Summary, January 1996, 22 p.

1996b, Ambient Monitoring Network: Lower Delaware Drainage Basin, 1995-96 benthic macroinvertebrate data: Trenton, New Jersey, Executive Summary, July 1996, 22 p.

Novotny, Vladimir, and Chesters, Gordon, 1981, Handbook of nonpoint pollution sources and management: New York, Van Nostrand Reinhold Company, 555 p.

Parker, G.G., Hely, A.G., Keighton, W.B., and Olmsted, F.H., 1964, Water resources of the Delaware River basin: U.S. Geological Survey Professional Paper 381, 200 p. 


\section{REFERENCES CITED-Continued}

Price, C.V., and Schaefer, F.L., 1995, Estimated loads of selected constituents from permitted and nonpermitted sources at selected surface-water-quality stations in the Musconetcong, Rockaway, and Whippany River Basins, New Jersey, 1985-90: U.S. Geological Survey Water Resources Investigations Report 95-4040, 28 p.

Rand, G.M., and S.R. Petrocelli, 1985, Fundamentals of Aquatic Toxicity: Methods and Applications: Washington, D.C., Hemisphere Publishing Corporation, 666 p.

Reed, T.J., and Hunchak-Kariouk, Kathryn, 1995, Surface-water temperature statistics for streams in New Jersey and vicinity, 1955-93: U.S. Geological Survey Open-File Report 95-196, $142 \mathrm{p}$.

Robinson, K.W., and Pak, Connie, 1993, New Jersey stream water quality: U.S. Geological Survey Water-Supply Paper 2400, p. 395-402.

Rosensteel, B.A., and Strom, P.F., 1991, River phosphorus dynamics and reservoir eutrophication potential: Water Resources Bulletin 27:6, p. 957-965.

Ruffner, J.A., and Bair, F.E., eds., 1977, The weather almanac (2d ed.): New York, Avon Books, $35 \mathrm{p}$.

SAS Institute Inc., 1990, SAS/GRAPH software reference, version 6 (1st ed.): Cary, N.C., v. 1,794 p.

Sawyer, C.N., and McCarty, P.L., 1978, Chemistry for environmental engineering: New York, McGraw-Hill, Inc., 532 p.

Schornick, J.C., Jr., and Fishel, D.K., 1980, Effects of storm runoff on water quality in the Mill Creek drainage basin, Willingboro, New Jersey: U.S. Geological Survey Water-Resources Investigations Report 80-98, 111 p.

Schornick, J.C., Jr., and Ram, N.M., 1978, Nitrification in four acidic streams in southern New Jersey: U.S. Geological Survey Water-Resources Investigations Report 77-121, 51 p.

Skougstad, M.W., Fishman, M.J., Friedman, L.C., Erdmann, D.E., and Duncan, S.S., 1979, Methods for determination of inorganic substances in water and fluvial sediments: U.S. Geological Survey Techniques of Water-Resources Investigations, book 5, chap. A1, $626 \mathrm{p}$.

U.S. Geological Survey, 1984, National Water Summary 1984: U.S. Geological Survey WaterSupply Paper 2275, 467 p.

Vowinkel, E.F., and Foster, W.K., 1981, Hydrologic conditions in the Coastal Plain of New Jersey: U.S. Geological Survey Open-File Report 81-405, 39 p. 


\section{REFERENCES CITED—Continued}

Wershaw, R.L., Fishman, M.J., Grabbe, R.R., and Lowe, L.E., 1987, Methods for the determination of organic substances in water and fluvial sediments: U.S. Geological Survey Techniques of Water-Resources Investigations, book 5, chap. A3, 80 p. 